\title{
Design and Modeling of Centralized Distribution Network for the DC House Project
}

\author{
A Thesis \\ presented to \\ the Faculty of California Polytechnic State University, \\ San Luis Obispo
}

\author{
In Partial Fulfillment \\ of the Requirements for the Degree \\ Master of Science in Electrical Engineering
}

by

Harpreet S. Bassi

June, 2013 
(C) 2013

Harpreet S. Bassi

ALL RIGHTS RESERVED 
COMMITTEE MEMBERSHIP

TITLE:

AUTHOR:

DATE SUBMITTED:

COMMITTEE CHAIR:

COMMITTEE MEMBER:

COMMITTEE MEMBER:
Design and Modeling of Centralized Distribution Network for the DC House Project

Harpreet S. Bassi

June, 2013

Dr. Taufik, Professor, Electrical Engineering

Dr. Ali O. Shaban, Professor, Electrical Engineering

Dr. Tina Smilkstein, Professor, Electrical Engineering 


\begin{abstract}
Design and Modeling of Centralized Distribution Network for the DC House Project
\end{abstract} Harpreet S. Bassi

This thesis focuses on the design, modeling, simulation, and performance evaluation of Centralized Distribution Network for the DC House Project. Power System Computer Aided Design (PSCAD) is used to model a Centralized PV Source, Battery Bank, and Distribution Network for 25 DC Houses. Design and modeling of each component in the proposed system are described. For the performance evaluation, emphasis is on voltage stability and system reliability under different operating conditions. Results from the simulation demonstrate the feasibility of the proposed Centralized Distribution Network for the DC House Project to support the houses during non-generation periods and distribution network voltage stability under different operating conditions. Cost analysis also shows the feasibility of the proposed system as compared to commonly used AC distribution network.

Keywords: DC House, Centralized Distribution Network, Solar Power, Boost Converter, Buck Converter, Maximum Power Point Tracking, Battery Bank, Voltage Stability, AC distribution network. 


\section{ACKNOWLEDGMENTS}

I would like to begin by thanking my advisor, Dr. Taufik. I am grateful for his assistance and guidance throughout the graduate program. I would also like to thank rest of my graduate committee, Dr. Ali O. Shaban, and Dr. Tina Smilkstein.

Foremost, I would like to express my deepest gratitude to my family; especially to my late brother Sukhvir Bassi. My brother was a person, I looked up too and could always count on when things weren't going so well. Without his love and support none of this would have been possible. Puneetpal Kaur provided emotional and technical support that can never be repaid. In addition, I would like to say thanks to my friends for their support, and making college a great experience. 


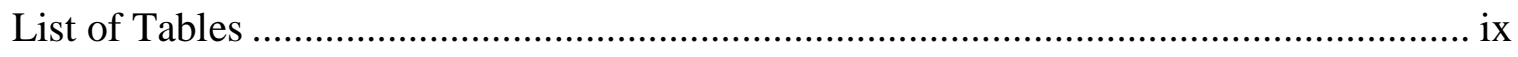

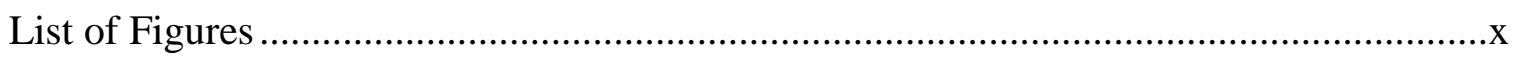

Chapter

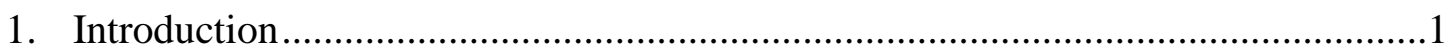

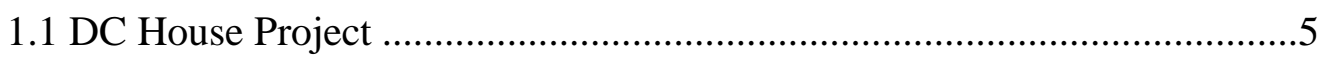

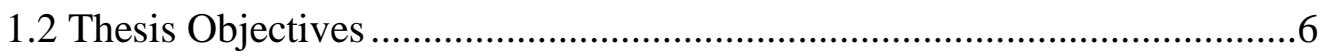

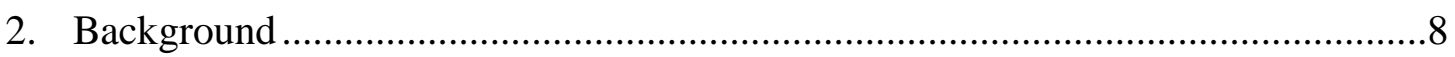

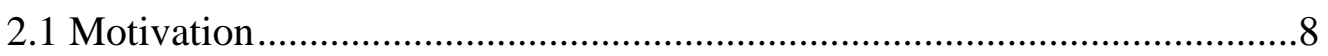

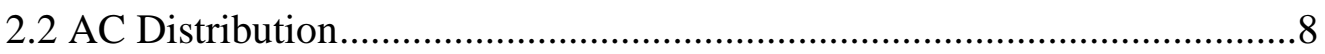

2.2.1 AC Distribution Infrastructure .........................................................

2.2.2 Disadvantages of AC Distribution ...................................................

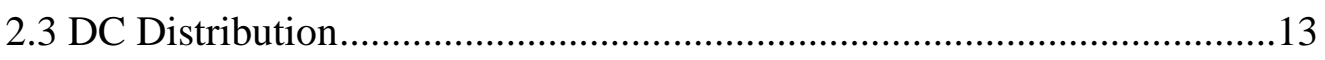

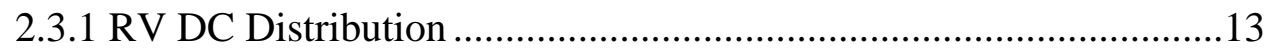

2.3.2 400 VDC Distribution in Telco and Data Centers .............................15

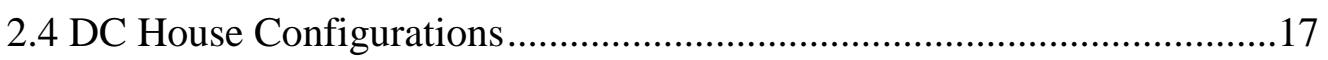

2.4.1 Individual DC House Configuration .................................................17

2.4.2 Multiple DC Houses Configuration .................................................22

2.4.3 Centralized Distribution Network for DC Houses.............................23

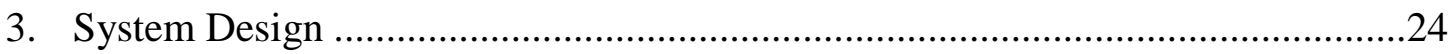

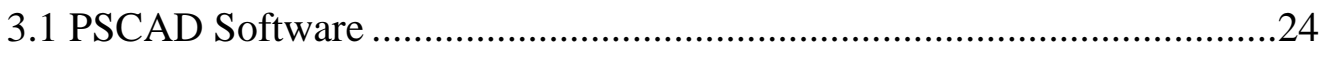

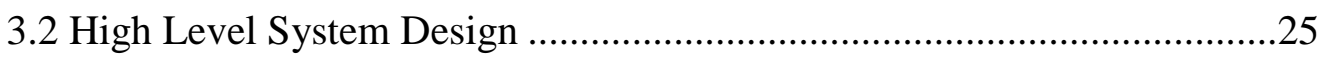

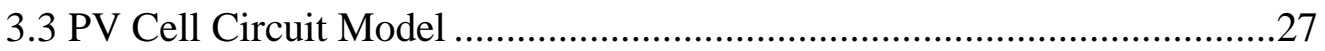

3.3.1 PV module PSCAD Implementation ...................................................31

3.4 PV Maximum Power Point Tracking.........................................................34

3.5 Boost Converter Operation ....................................................................... 
3.5.1 Boost Converter PSCAD Implementation ..........................................43

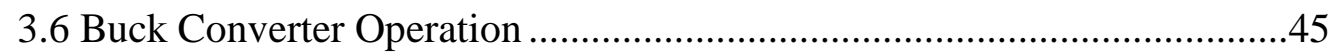

3.6.1 Buck Converter PSCAD Implementation ..........................................49

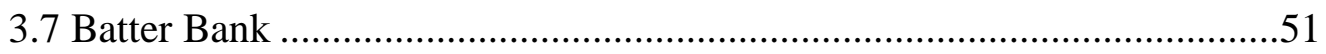

3.7.1 Battery Bank PSCAD Implementation ..............................................53

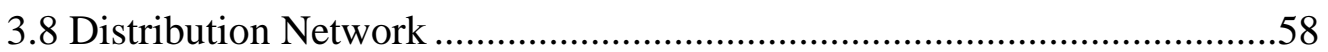

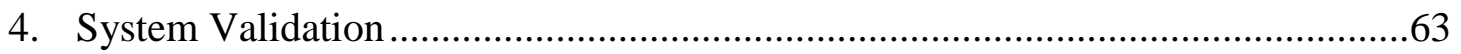

4.1 MPPT and Boost Converter Validation ....................................................63

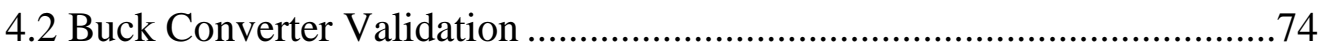

4.3 Voltage Stability of the Distribution Network...........................................76

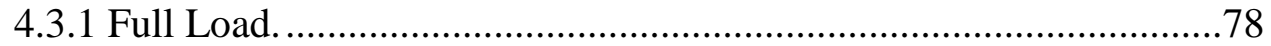

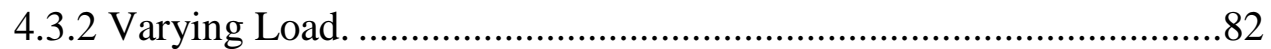

4.3.3 Varying Number of Houses Operating ..............................................84

4.4 PV Charging the Battery and Supplying the Load.....................................87

4.5: Battery Bank Supplying the Load............................................................91

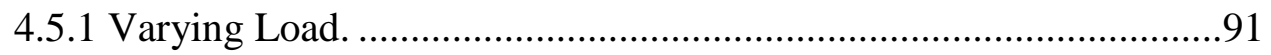

4.5.2 Varying Number of Houses Operating ...........................................95

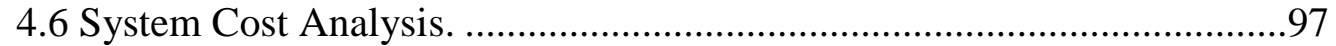

4.6.1 PV Array and MPPT Charge Controller Cost.....................................97

4.6.2 Battery Bank Cost.........................................................................100

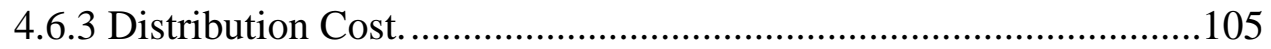

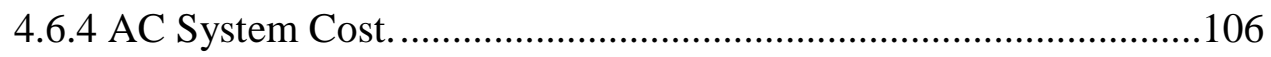

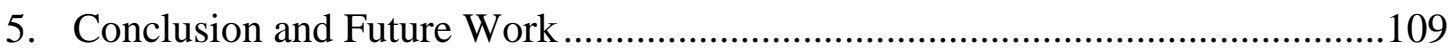

5.1 Summary and Conclusion .........................................................................109

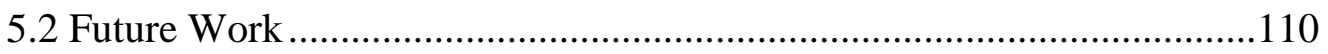

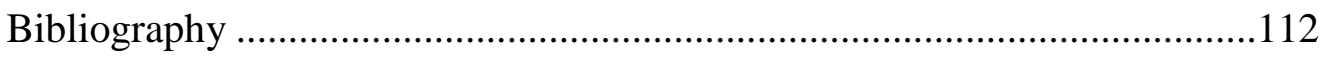

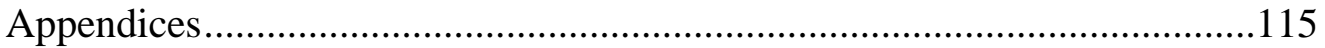

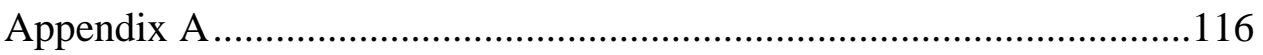

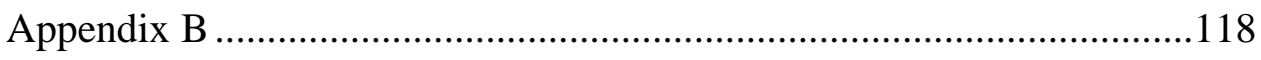

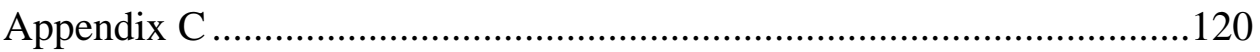


Appendix D.

Appendix E....

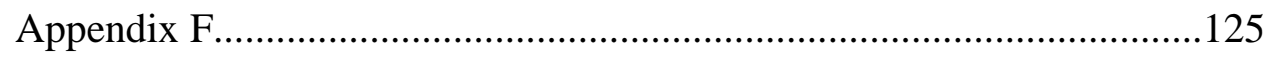

viii 


\section{LIST OF TABLES}

Table

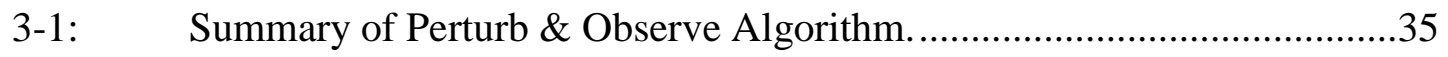

3-2: $\quad$ Comparison of Flooded Lead-Acid and VRLA Battery Types [23]..........52

3-3: $\quad$ ASCR Conductor Specifications Chart.............................................61

4-2: $\quad$ PV Output Voltage, Current, and Power with Varying Temperature........66

4-3: $\quad$ PV Output Voltage, Current, and Power with Varying Irradiance............68

4-3: $\quad$ PV Output Voltage, Current and Power with Varying Load.....................70

4-4: $\quad$ Summary of the Boost Converter Voltages and Duty Cycle with

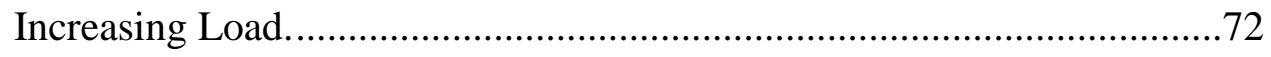

4-5: $\quad$ Summary of the Buck Converter Voltages and Duty Cycle with Increasing

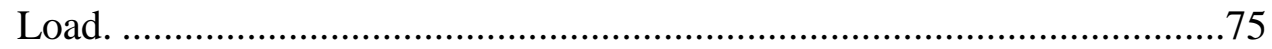

4-6: $\quad$ Efficiency Summary of the Buck and Boost Converters with Increasing

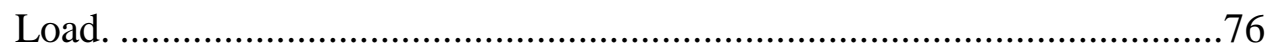

4-7: Distribution Network Voltages with 5 to 25 Houses at 500W. ................85

4-8: $\quad$ PV Array Sizing and Cost Calculations................................................98

4-9: $\quad$ Summary of PV Cost for $85 \%$ and $75 \%$ System Efficiency.....................99

4-10: $\quad$ MPPT Charge Controller Cost..............................................................100

4-11: $\quad$ Battery Bank Sizing for 2 Days of Autonomy Storage...........................102

4-12: $\quad$ Battery Cost Varied with System Size and Storage Capacity...................103

4-13: Distribution Wiring Cost for a $10 \mathrm{~kW}$ System.......................................105

4-14: Distribution Wiring and Boost Converter Cost. .....................................105

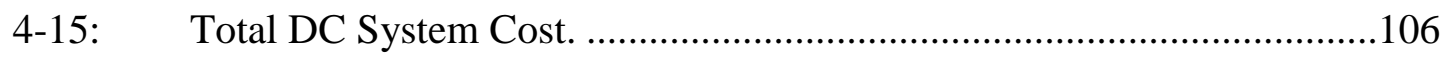

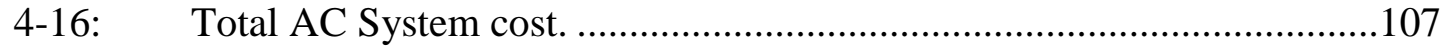




\section{LIST OF FIGURES}

Figure

Page

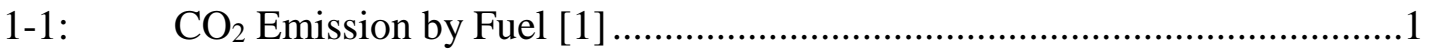

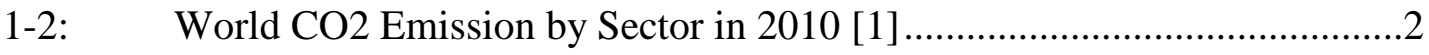

1-3: $\quad$ Cumulative Installations of Worldwide PV by the End of 2011 [3]...........3

2-1: $\quad$ Transmission and Distribution Grid Structure within the Power

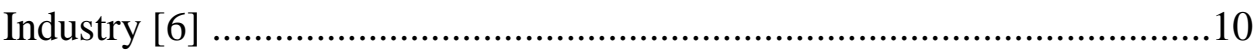

2-2: $\quad$ Skin Depth of AC Conductor with Increasing Frequency [6] ..................11

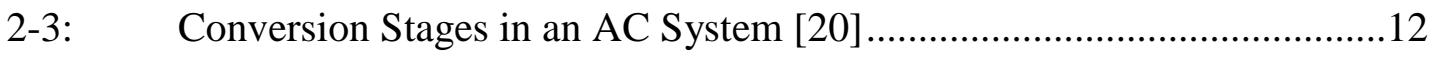

2-4: $\quad$ 110/120V - 30 Amp RV Wiring Configurations [5] ...............................14

2-5: $\quad$ Conventional 480Vac Telco Center Distribution in the United States

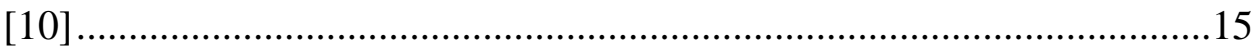

2-6: $\quad$ Proposed Facility-level 400V DC Power Distribution [10]......................16

2-7: $\quad$ Comparison of Distribution Systems Efficiencies as a Function of

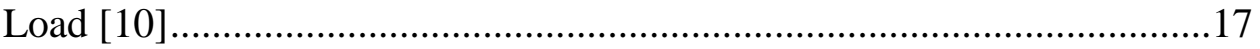

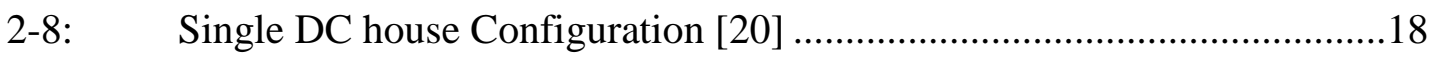

2-9: $\quad$ DC Light Bulb at Full Load from 48 VDC Input [4] ..............................20

2-10: $\quad$ Multiple Input Single Output DC-DC Converter Board [16] ...................21

2-11: Multiple DC Houses Configuration [20] …..........................................22

2-12: $\quad$ Proposed Centralized Distribution Network for DC Houses [20] .............23

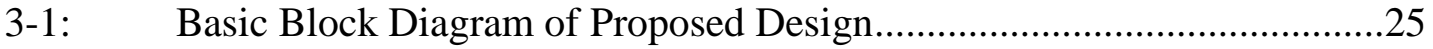

3-2: $\quad$ Detailed Block Diagram of the Proposed System Design ........................27

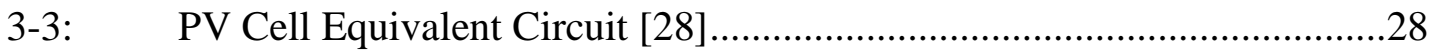

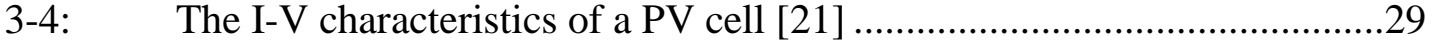

3-5: $\quad$ PV Module Components available in PSCAD ........................................31

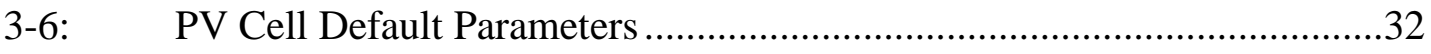

3-7: $\quad$ PV Module and PV Array Parameters ...............................................33 
3-8: $\quad$ PV Module I-V and Power Characteristics...............................................33

3-9: $\quad$ PSCAD MPPT Component (left), and Parameters (right) ...........................34

3-10: Incremental Conductance Based Algorithm MPPT [30] .............................37

3-11: $\quad$ The Controller used to drive the Boost Converter Switch for MPPT.........38

3-12: $\quad$ Boost Converter Block Diagram [32] ………...........................................

3-13: $\quad$ Conduction Modes of DC-DC Converters [32] ……………………….......39

3-14: Boost Converter CCM Switch ON State [32] .............................................40

3-15: $\quad$ Boost Converter CCM Switch OFF State [32] .........................................41

3-16: Boost Converter Inductor, Switch and Diode Current [32] .......................42

3-17: Boost Converter connected to the PV Array in PSCAD ............................43

3-18: $\quad$ Buck Converter Block Diagram [32] .......................................................45

3-19: $\quad$ Buck Converter CCM Switch ON State [32] ...........................................46

3-20: $\quad$ Buck Converter CCM Switch OFF State [32] ..........................................4

3-21: Buck Converter CCM Waveforms [34] ..................................................48

3-22: $\quad$ Buck Converter Cascaded with Boost Converter in PSCAD .....................49

3-23: Buck Converter Switch Controller for Regulating Output Voltage at

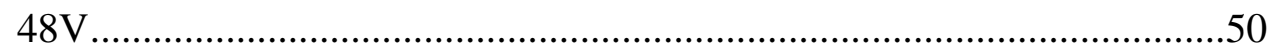

3-25: Cell Discharge Characteristics of Four Battery Types ..............................51

3-26: Battery Equivalent Circuit Diagram [18]................................................53

3-27: Battery Custom Component in available in PSCAD .................................54

3-28: $\quad$ Lead-Acid Battery Parameters .................................................................55

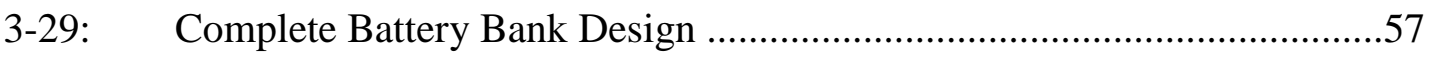

3-30: Boost Converter (top) and Controller (bottom) within the Sub-Module

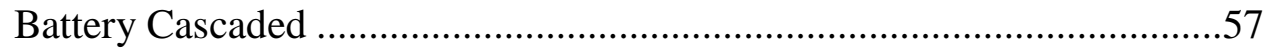

3-31: Distribution Network Design for 25 DC Houses ......................................58

3-32: $\quad$ Magnified view of Feeder C Supplying Power to 5 DC Houses ................59

3-33: DC Equivalent Circuit Diagram [8] ......................................................60

3-34: Boost Converter (top), and its Switch Controller (bottom) used in

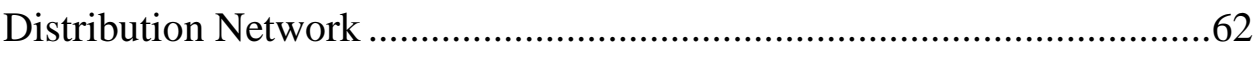

4-1: $\quad$ Complete System Design Implemented in PSCAD .....................................64 
4-2: $\quad$ PV Module I-V Characteristic with Varying Solar Radiation (left) and Temperature (right)

4-3: $\quad$ PV Array output Voltage (top), Current (middle), and Power (bottom) with Varying Temperature.

4-4: $\quad$ PV Array output Voltage (top), Current (middle), and Power (bottom)

with Varying Solar Irradiance ...............................................................68

4-5: $\quad$ PV Array Voltage Operating Point as the Load Increases.....

4-6: $\quad$ PV Array operating Voltage (top), Current (middle), and Power (bottom)

with Varying Load .70

4-7: $\quad$ Boost Converter Input and Output Voltages with increasing Load . .72

4-8: $\quad$ Boost Converter Inductor Current (top) and Magnified View of Inductor Current at Full Load (bottom)

4-9: $\quad$ Buck Converter Input and Output Voltages with increasing Load. .74

4-10: $\quad$ PV Output Power (green) and Buck Converter Output Power (blue) with Varying Load .75

4-11: $\quad$ Centralized Distribution Network Design for 25 DC Houses .77

4-12: Voltages at Five locations in the Distribution Network at Full Load ........78

4-13: Current at Five Locations in the Distribution Network at Full Load.........80

4-14: $\quad$ Power in the main DC Distribution Cable (Top) and Power delivered to 2 individual Houses (bottom).

4-15: Voltage Measurements at Five Locations as load is incremented from $100 \mathrm{~W}$ to $500 \mathrm{~W}$ in steps of $50 \mathrm{~W}$

4-16: Current Measurements at Five Locations as load is incremented from $100 \mathrm{~W}$ to $500 \mathrm{~W}$ in steps of $50 \mathrm{~W}$.

4-17: $\quad$ Power Measurements at Five Locations as load is incremented from 100W to $500 \mathrm{~W}$ in steps of $50 \mathrm{~W}$

4-18: $\quad$ Voltage Measurements at Five Locations as Number of Houses is incremented .85 
4-19: Current Measurements at Five Locations as Number of Houses is incremented

4-20: $\quad$ Power Measurements at Five Locations as Number of Houses is

incremented .86

4-21: Battery Storage during Peak Sun Hours (dark yellow) and Battery Supplying Load (green) .87

4-22: $\quad$ Power Supplied to the Battery from PV Array ………………………........8

4-23: $\quad$ Battery Current (blue) and Voltage (green) ...............................................8

4-24: $\quad$ Voltage Measurements of the Distribution Network at Five Locations

While the Battery Bank is being charged

4-25: $\quad$ Current Measurements of the Distribution Network at Five Locations

While the Battery Bank is being charged

4-26: $\quad$ Power Measurements of the Distribution Network at Five Locations While the Battery Bank is being charged .90

4-27: Voltage Measurements of Distribution Network at Five Locations as Load is increased from $100 \mathrm{~W}$ to $500 \mathrm{~W}$ in steps of $50 \mathrm{~W}$ (Powered from Battery)

4-28: Current Measurements of Distribution Network at Five Locations as Load is increased from $100 \mathrm{~W}$ to $500 \mathrm{~W}$ in steps of 50W (Powered from Battery) .93

4-29: $\quad$ Power Measurements of Distribution Network at Five Locations as Load is increased from $100 \mathrm{~W}$ to $500 \mathrm{~W}$ in steps of 50W (Powered from Battery)

4-30: Battery Bank State of Charge (SOC)

4-31: Voltage Measurements of Distribution Network at Five Locations as number of houses is incremented (Powered from Battery)

4-32: $\quad$ Current Measurements of Distribution Network at Five Locations as number of houses is incremented (Powered from Battery)

4-33: $\quad$ Power Measurements of Distribution Network at Five Locations as number of houses is incremented (Powered from Battery) .96 


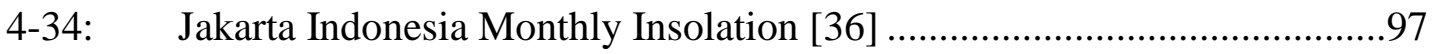

4-35: $\quad$ DC Distribution PV Cost with 85\% and 75\% Efficiency ........................99

4-36: Battery Bank Cost with Increasing System Size and Storage Capacity ..104

4-37: DC System Cost at 85\% Efficiency and AC System 75\% Efficiency .....108 


\section{CHAPTER 1}

\section{Introduction}

More than $80 \%$ of world's energy supply comes from fossil fuel sources like petroleum, coal, and natural gas. Fossil fuels are nonrenewable energy sources since they take millions of years to form. When used, fossil fuels release carbon into the atmosphere which contributes to the greenhouse gases. Global $\mathrm{CO}_{2}$ emissions are rising every year due to the increasing demand of energy consumption as shown in Figure 1-1 [1]. Figure 1-2 shows the $\mathrm{CO}_{2}$ emissions by sectors of the energy consumption [1].

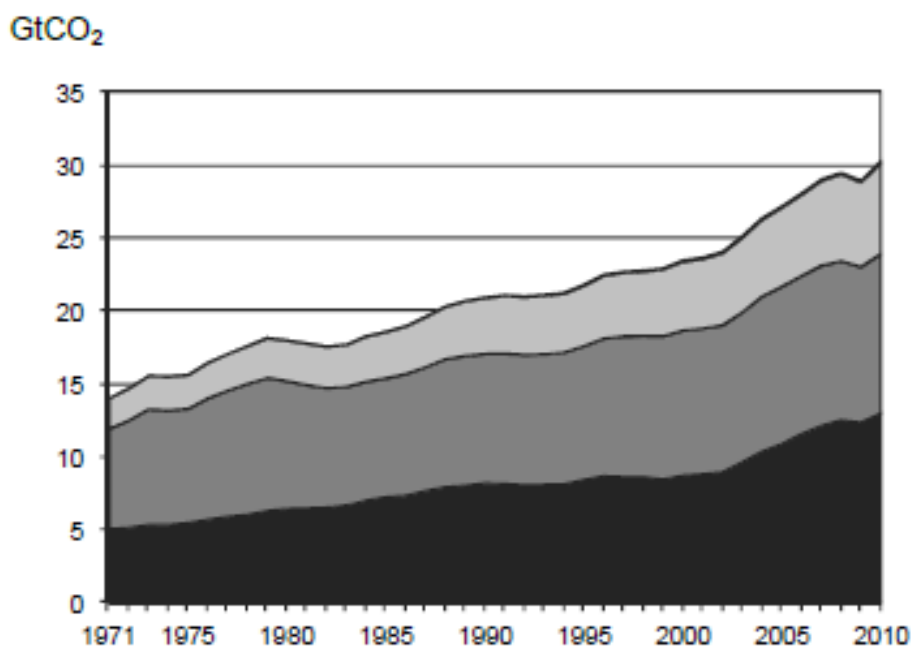

Figure 1-1: $\mathrm{CO}_{2}$ emission by fuel [1]

The first study on $\mathrm{CO}_{2}$ as greenhouse gas was published by Swedish scientist Svante Arrhenius in 1896. Before the large-scale use of fossil fuels, which was approximately 100 years ago, the atmosphere contained an average $275 \mathrm{ppm} \mathrm{CO}_{2}$. Today 
the estimate is $380 \mathrm{ppm} \mathrm{CO}_{2}$ in the atmosphere which is a direct result of the combustion of fossil fuels. After 100 years of burning fossil fuels, the earth's average surface temperature has risen from $57^{\circ} \mathrm{F}$ to $58.3^{\circ} \mathrm{F}$ [2]. This is a small change in temperature, but potentially a large difference in climate which has led to glaciers melting and sea levels rising. If we continue to use fossil fuels until they run dry, the $\mathrm{CO}_{2}$ concentration is expected to increase to about $550 \mathrm{ppm}$. The Intergovernmental Panel on Climate Change (IPCC) suggests that the average surface temperature will likely rise another 2.0 to 11.5 ${ }^{\circ} \mathrm{F}[2]$.

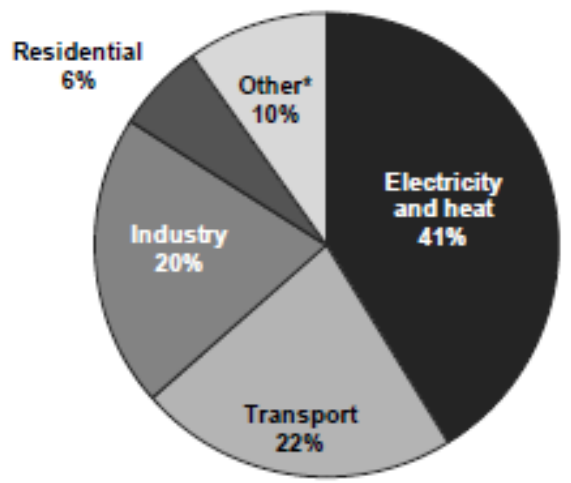

* Other includes commercial/public services, agriculture/forestry, fishing, energy industries other than electricity and heat generation, and other emissions not specified elsewhere.

Figure 1-2: World CO2 emission by sector in 2010 [1]

Global warming issue has made renewable sources of energy more attractive. Renewable energy is derived from natural processes (e.g. sunlight and wind) that are replenished at faster rate than they are consumed. Solar, wind, geothermal, hydro and some forms of biomass are common sources of renewable energy. Solar and wind have grown the most popular over the past decade. Global wind power capacity was 238 
(GW) at the end of 2011, up from just $18 \mathrm{GW}$ at the end of 2000. The advancements in electronics and renewable energy have enabled us to produce energy out of resources which was impossible 50 years ago. Renewable energy provides secure reliable power with economic productivity and with little to no environmental impact.

Solar photovoltaic (PV) directly converts solar energy into electricity using PV cell which is a semiconductor device. Figure 1-3 shows that the PV installation around the world has increased exponentially in the last decade. This exponential increase in PV installation is due to multiple variables that play a big role in the PV market. PV cell efficiency has increased, and simultaneously prices have been going down due to more manufacturer competition and government subsidies [3]. These advancements in the PV technology and reduction in the prices have made the exponential growth possible.

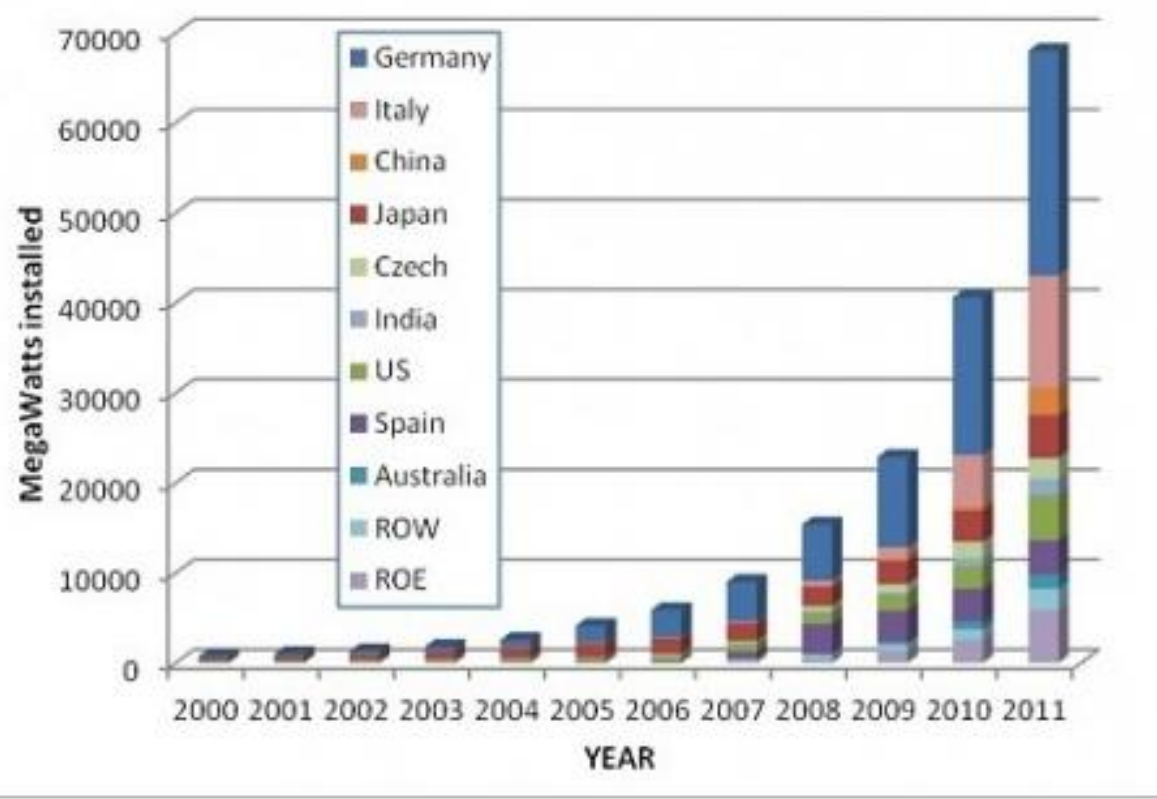

Figure 1-3: Cumulative installation of worldwide PV by the end of 2011 [3] 
Renewable sources of energy also give us the chance to provide energy to rural areas mainly in under-developed countries which are not likely to be connected to electric grid. Still today there are about 1.3 billion people around the world who do not have access to electricity. About 587 million of this population lives in Africa, approximately 675 million in Asia, and 55 million in Eastern Europe/Eurasia [4]. Generally this population lives in rural areas which are farther away from the urban electric grid, thus connecting them to an electric grid is not economically viable. The capital required to build high voltage transmission system for longer distances is very expensive. According to Edison Electric Institute (EEI), from 2004-2008, United States invested \$4.6M/GW/year, New Zealand invested \$22.M/GW/year, and the Netherlands invested $\$ 12.0 \mathrm{M} / \mathrm{GW} /$ year in high voltage transmission [4]. The cost for lower than $230 \mathrm{kV}$ will be more for longer distance due to higher resistive losses $\left(I^{2} \mathrm{R}\right)$ in the grid. This is because as the transmission voltage is lowered, the resulting current increases proportionally and the losses in the system increase accordingly.

People who live in rural villages in underdeveloped countries are mostly poor and are deprived of most basics of human rights, and of economic opportunities to improve their standard of living without access to electricity. Undoubtedly rural electrification programs face major obstacles. Utility companies need to have high initial capital along with high operation costs because of the low population densities in rural areas. Therefore, it does not create a business advantage to invest on an expensive grid infrastructure to provide electricity to these people especially since their consumption will be very low (mostly for lighting). Moreover, building infrastructure for these areas 
may often create conflicts with the local communities, and farmers due to rights of way for the construction and maintenance of electricity lines.

Renewable energy is an abundant source of energy which could be used to provide electricity for those unfortunate people in rural areas with no access to electricity. The good news is that many of these rural areas happen to be in locations where renewable energy sources are abundant. For example, majority of this poor population live within plus or minus 30 degrees of latitude around the world.

\subsection{House Project}

Local electrical network for the unfortunates seems to be a feasible option available through renewable sources of energy. The DC house project initiated at Cal Poly is an extension to that idea along with its futuristic benefits. DC house is a project for the unfortunates. It aims to deliver the most basic electric needs of the modern world to those in need by utilizing renewable energy sources. The DC house, as the name implies, operates fully on Direct Current.

Over the century scientific and economic developments have led to expansion of the electric grid around the world. But as mentioned earlier, still today, after 150 years of early inventions of electricity, there are approximately 1.3 billion people around the world who do not have access to electricity. Financial disadvantages and remote locations of these populations are the two main reasons for their governments not to have the incentive to connect them to their nations' grids. The DC house project aims to address 
these problems and is divided into three phases. Phase 1, which was completed in June 2011, focused on the single DC house development as the basic unit. It included designs of generator sources such as: Hydro-power generator, a photovoltaic power generator, a human-powered generator and a wind-powered generator. Phase 1 also included the designs for multiple-input DC-DC converter, system level design of DC house (DC level and loads.)

Phase 2 of the project was concluded in June 2012. This phase looked at the optimization, protection, and implementation of single DC house. Several important milestones were completed during this phase such as a temporary DC house model at Cal Poly, DC Lightbulb, publications and presentations of DC house.

Now the project is in Phase 3, which will conclude in June 2013. Phase 3 of the project is focusing on a centralized DC System, where centralized PV panels are used to distribute power to a larger village rather than strictly to an individual house.

\subsection{Thesis Objective}

This thesis falls under the third phase of the DC House project which focuses on the design, modeling, simulation, and performance evaluation of the centralized distribution network for the DC House. Power System Computer Aided Design (PSCAD) is used to simulate the network. This network would include standalone solar PV source working with Maximum Power Point Tracker (MPPT) to maximize the power production under different weather conditions. The feasibility, operation, and performance of the 
DC distribution system are the main goals of the study. Additionally as part of the study, the implementation of the PV sources with MPPT will consider various conditions that will affect the power generation and voltage stability in the local DC grid. Load flow analysis for as many as 25 houses of $500 \mathrm{~W}$ and their different layouts will be modeled and analyzed. Backup batteries to provide stability to the grid and backup power during night and non-power generating conditions will also be studied and considered. 


\section{CHAPTER 2}

\section{Background}

\section{1: Motivation}

The DC house project is a solution to challenges of rural electrification. It will provide self-sustaining DC power through various forms of renewable energy such as

photovoltaic, hydropower, wind, and human-powered generation. The generated power is used to provide the most basic living necessities such as room lighting, electric stove for cooking, space heating, cooling and refrigeration. This renewable form of energy will replace liquid fuel, gas, biomass or animal waste, which currently help sustain the daily energy necessities of rural areas in poor nations. This chapter will discuss the commonly used AC distribution system and the advantages of choosing DC distribution for the DC house project.

\section{2: $\quad$ AC Distribution}

In the 1880s, Tesla and Edison went head to head with the "War of Currents" as it is called [18]. The biggest challenge was to set up an electrical-grid network that would send power over long distance with minimal losses. This required voltage step-up at the generation side and step-down on the distribution side. Westinghouse's invention of the transformer made it possible for voltage to step-up and step-down in the alternating current, thus making it the stronger candidate out of the two. Tesla won his battle for 
alternating current by proving it was the better choice at that time given all the electric equipment capabilities. This victory paved the way for the AC infrastructure to build over the past century.

\subsection{1: AC Distribution Infrastructure}

The grid "topology" used in an electrical energy distribution can vary according to practical constraints of budget, requirements for system reliability, and the load and generation characteristics. Figure 2-1 shows a typical power generation and distribution system used around the world [6]. The power generation sources include fossil fuels, nuclear, hydro, and renewables. Step-up transformers are used to step up the transmission grid voltage in hundreds of kilovolts in order to transmit power over long distances with minimum losses. The resistive power losses in electric transmission lines are directly related to the amount of current flowing through the conductor $\left(\mathrm{P}_{\text {loss }}=\mathrm{I}^{\wedge 2} \mathrm{R}\right)$. Once in the close proximity of the load, the voltage is stepped down and distributed at voltages required by the load (U.S domestic loads are supplied with $120 \mathrm{Vac}$ at $60 \mathrm{~Hz}$ ). The infrastructure needed for this classic generation, transmission, and distribution requires high initial investment. Along with high initial costs, the AC system is also very complex and has many disadvantages in power distribution when compared to a DC system. 


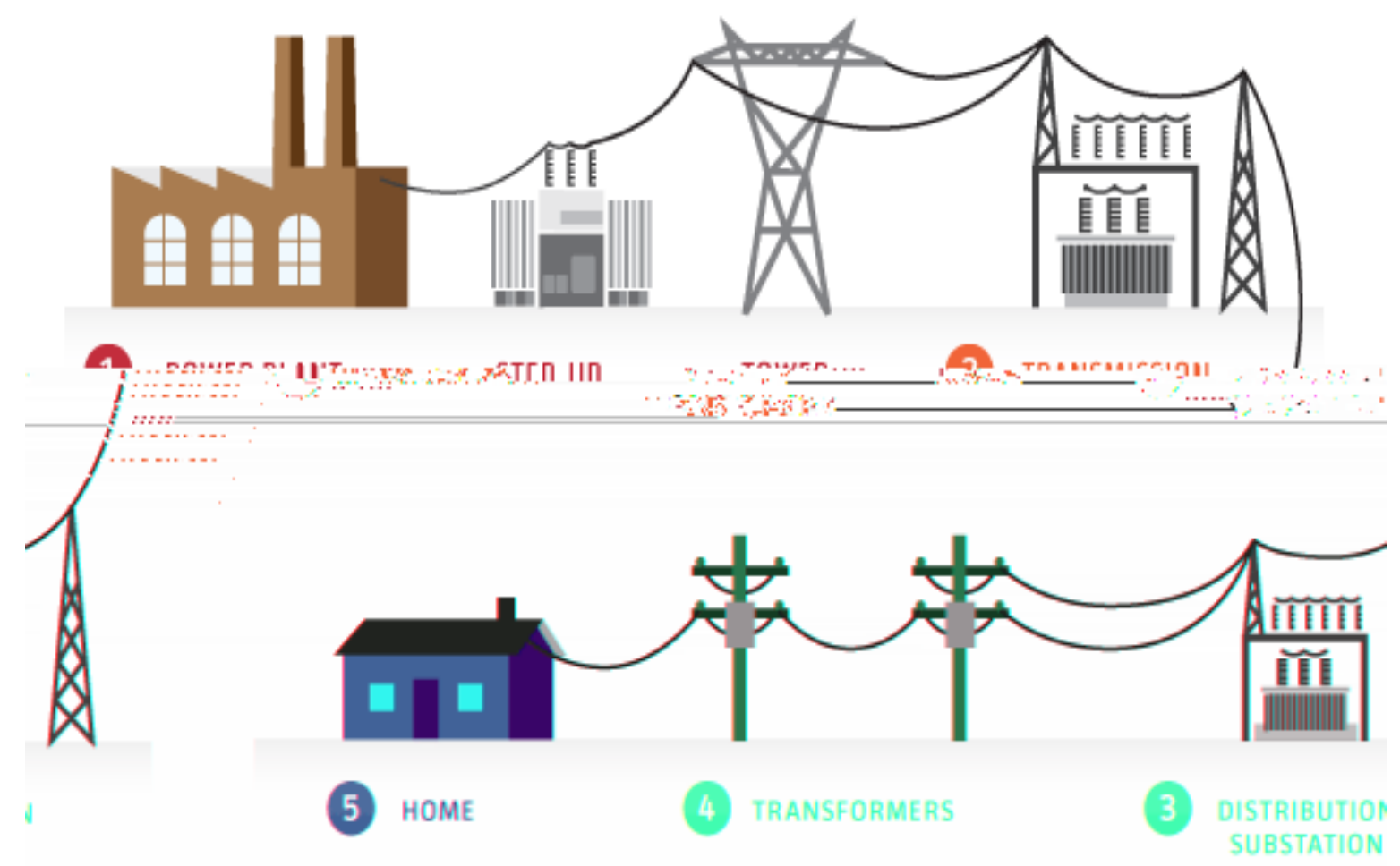

Figure 2-1: Transmission and Distribution Grid Structure within the Power Industry [6]

\subsection{2: Disadvantages of AC distribution}

One of the numerous disadvantages of an AC transmission line is its capacity to transmit power. The effective voltage of a conductor in an AC system is limited to 70.7\% of the peak value. A similar conductor in DC transmission can transmit approximately $30 \%$ more power because the peak and RMS values in DC are same. Also, the current density of alternating electric current is non-uniform and more current flows near the surface of the conductor than the core, known as the "Skin Effect". This condition decreases the amount of power that could be transmitted through a conductor because the 
middle portion of the conductor is not being used. As shown in Figure 2-2, the current density for a DC conductor is uniform throughout, which is not true in AC conductor [6]. In an $\mathrm{AC}$ conductor, skin depth decreases as the frequency of current increases, thus current only flows mainly near the surface of the conductor [6].

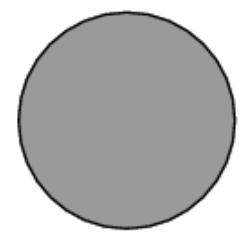

Cross-sectional area of a round conductor available for conducting DC current

"DC resistance"

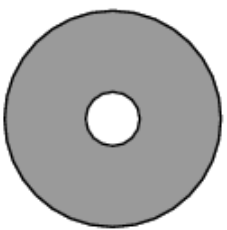

Cross-sectional area of the same conductor available for conducting low-frequency AC

"AC resistance"

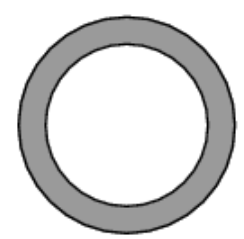

Cross-sectional area of the same conductor available for conducting high-frequency AC

"AC resistance"

Figure 2-2: Skin depth decreases with increasing frequency [6]

The Power Factor of the AC system is another variable that affects AC power transmission. The reactance of $\mathrm{AC}$ transmission lines lowers its Power Factor which leads to reactive power being drawn out of the generator, and subsequently less real power is delivered to the load. Another issue of an AC system is its frequency, which is required to be at $60 \mathrm{~Hz}$ for a stable system. An inaccurate frequency control does not allow efficient flow of power from multiple generators into the grid network. Another phenomenon in AC transmission is the Corona Discharge Effect in which electrical 
breakdown is caused by ionization of surrounding air of conductors at voltage amounts greater than that of the critical breakdown voltage [7].

Many of the domestic loads such as home appliance, electronics, and entertainment systems require DC power for their operation. The incoming AC from the power outlet has to be converted to DC in order for these loads to work. This AC to DC power conversion introduces power losses into the system. Figure 2-3 shows the conversion stages which are required in an AC system for the DC loads [20].

Additionally, in case of renewable sources, which (generate DC power), the current AC system requires two conversion stages before power could be delivered to the load.

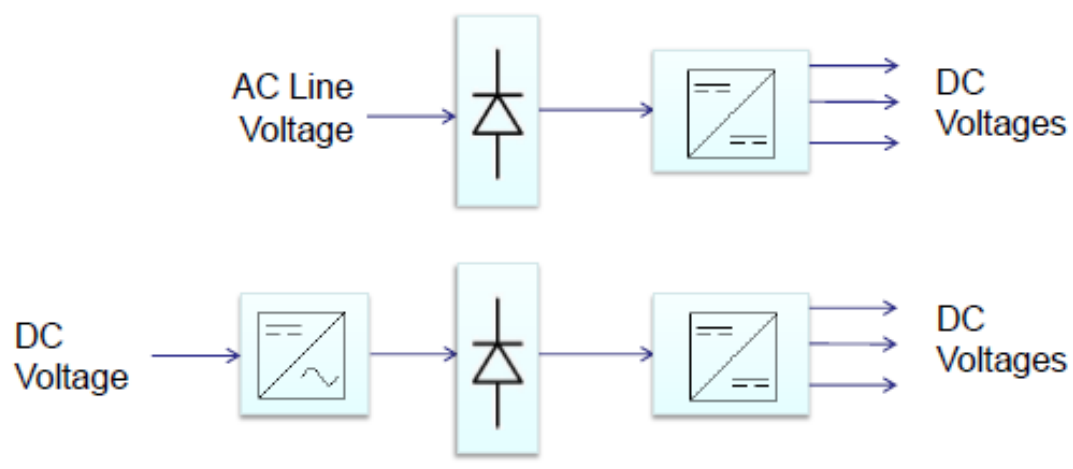

Figure 2-3: Conversion stages in an AC system [20]

A DC distribution system would eliminate the AC to DC conversion by more efficient DC-DC conversions. Another benefit of a DC system is that it is less costly since components are rated at lower voltages. Largely the DC distribution system is less complex, more efficient and consumes less space. However, AC system was preferred 
over DC system for the past century because DC did not have the capability to step-up or step-down voltage without the power electronic technologies. The power electronic industry has since developed highly reliable and well-performing technologies capable of these tasks, and DC distribution is now considered as an optimal solution to improve distribution efficiency.

\section{3: $\quad$ DC Distribution}

The idea of incorporating one or multiple renewable energy sources to support the DC system is unique. DC system features lack of frequency stability, reactive power issues, skin effect, and conversion losses compared to AC power system. Using direct current to distribute power is not a new concept. As mentioned before, Edison was promoting DC distribution network during the "War of Currents" era in 1890's. Also, RV, Telco and Data centers, aircraft, spacecraft, and ship already used DC distribution [11].

\subsection{1: $R V D C$ Distribution}

First example of an existing small DC power distribution system in use is an RV's electrical system, as illustrated in Figure 2.4 [5]. The RV's motor drives an alternator that produces AC voltage, which is rectified to 12-volt DC to charge the on-board batteries and supply power to the DC appliances. This 12-volt DC distribution has its own fuses, 
receptacle, and wiring. This system provides for the key components of an RV, such as light, water, heat, fans and motor, refrigeration, entertainment, and safety [5].

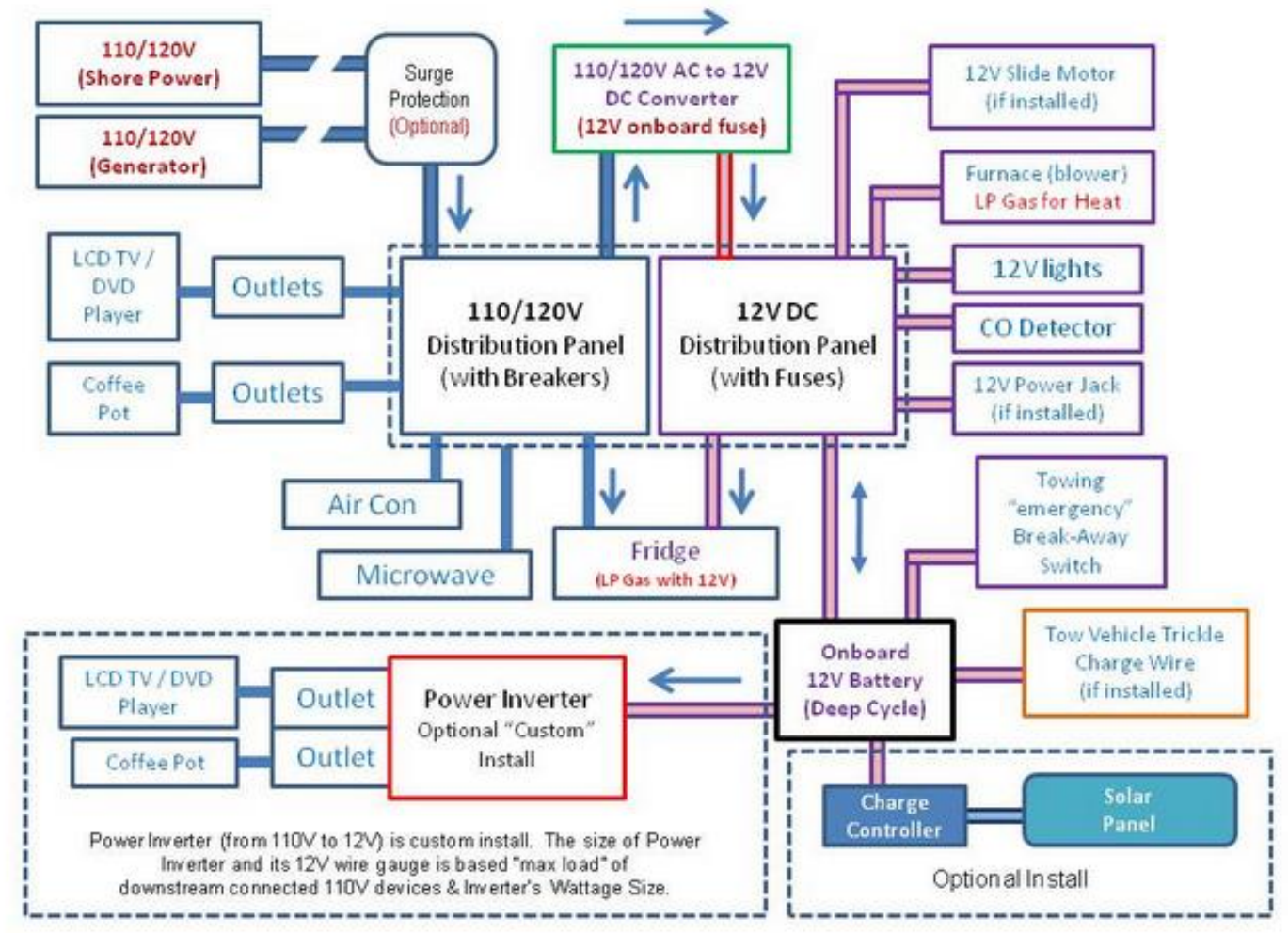

Figure 2-4: 110/120V - 30 Amp RV Wiring Configurations [5]

As displayed in Figure 2-4, there are cases when solar panels are also used to power the DC appliances and charge the batteries. In these cases, a charge regulator controls the power flow to the battery in order to protect from overcharging. Importantly, the DC system differentiates itself at this point because it is not necessary for the RV motor to be on as the basic appliances are running. This can be helpful in instances such as when the family is camping. Next example of a DC distribution system at a larger scale is Telco and Data Centers. 


\subsection{2: 400 VDC Distribution in Telco and Data Centers}

Telco and Data Centers around the world are major consumers of power. In a typical $480 \mathrm{VAC}$ data center (Figure 2-5), less than half of the power is delivered to the actual computer load, which includes microprocessors, memory and disk drives. The conventional power delivery architecture is burdened by many power conversion stages, as illustrated in Figure 2-5 [10]. Furthermore, each conversion stage creates inefficiency which wastes energy, produces heat, and increases the load on the center's cooling system.

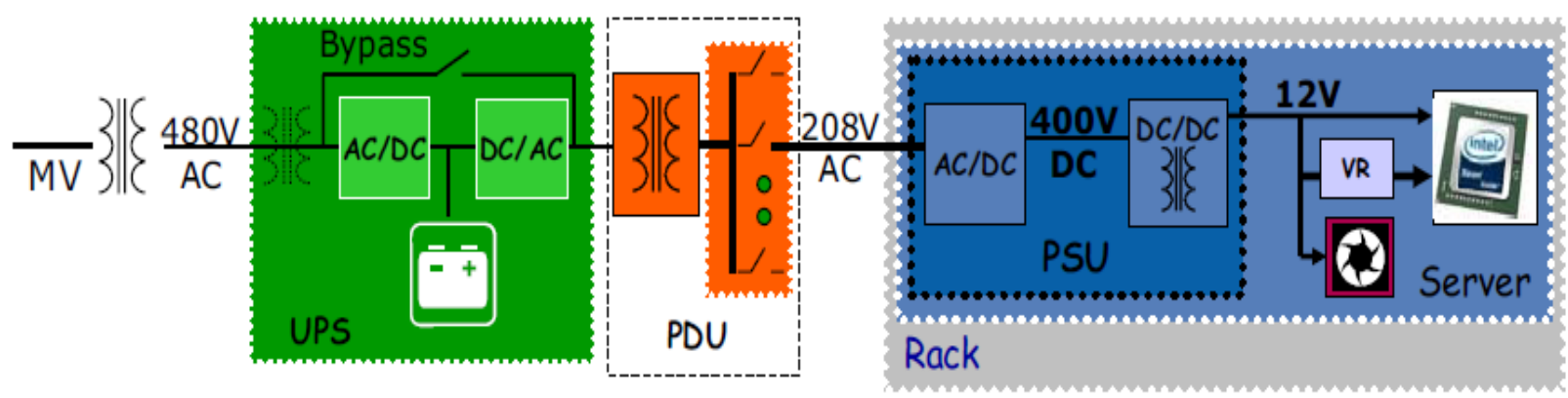

Figure 2-5: Conventional 480Vac distribution in the United States [10]

In [10], a 400 VDC distribution in Telco and Data center was evaluated to improve energy efficiency of the system. The findings of this study showed that system efficiency improved significantly in power delivery architectures when power conversion stages were eliminated by directly feeding 400 VDC (Figure 2-6) [10]. Figure 2-7 
displays the efficiency plots of power distribution architectures studied in [10] for the

Telco and Data Centers. This study concluded that the two electrical architectures, 400

VDC and 48 VDC, yield the highest efficiency because the conversion stages are eliminated.

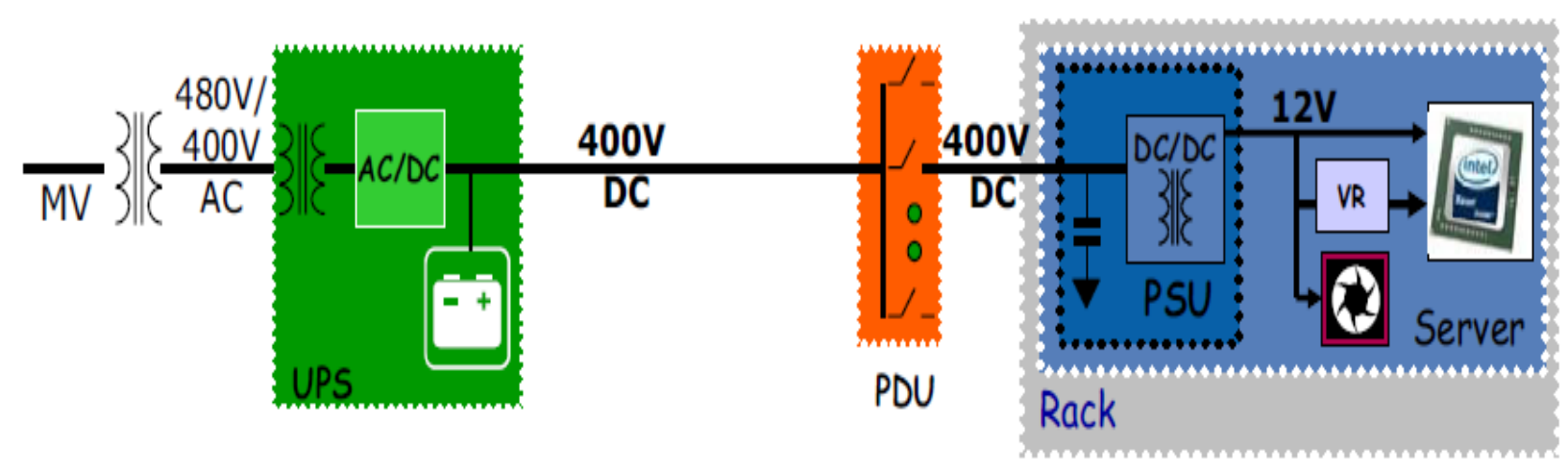

Figure 2-6: Proposed Facility-level 400V DC power distribution [10]

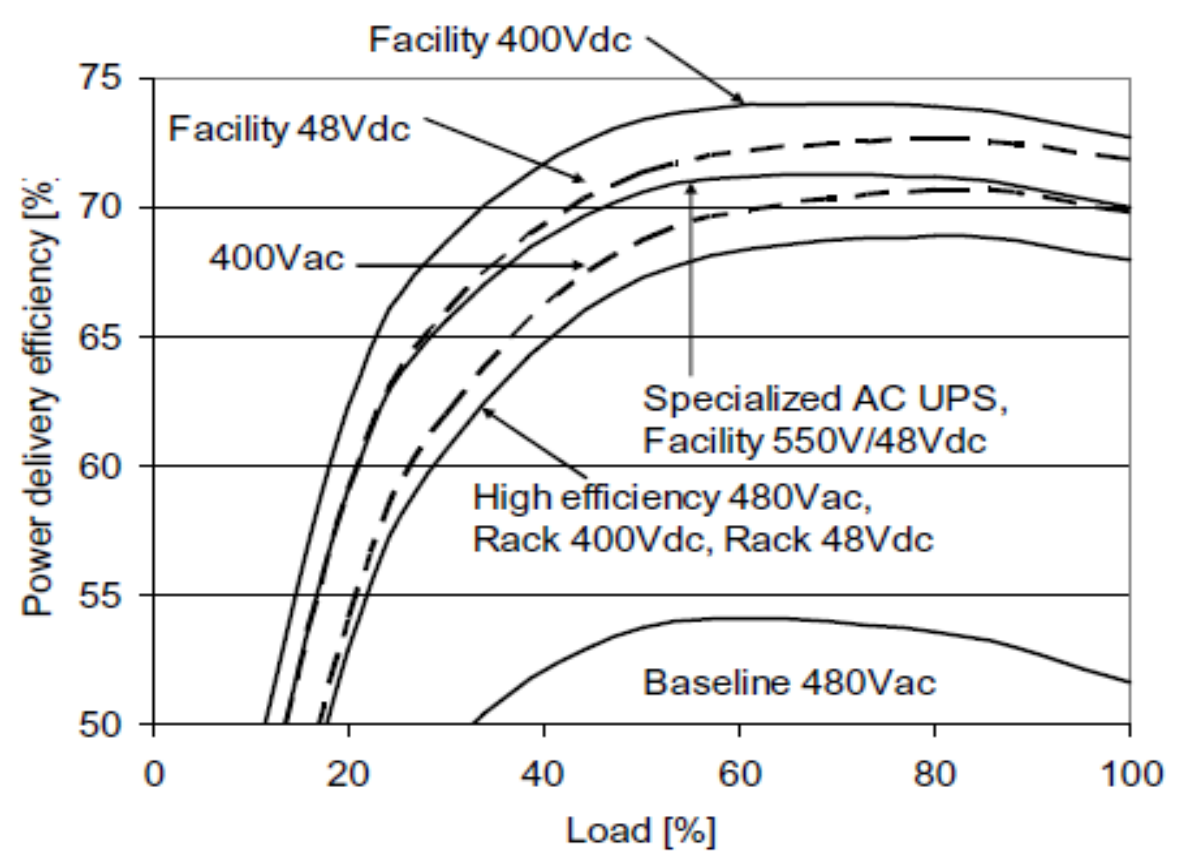

Figure 2-7: Comparison of calculated efficiencies as a function of load [10] 


\section{4: DC House Configurations}

There are three different configurations of DC house: Individual DC house, Multiple DC Houses, and Centralized DC System. These configurations are based on multiple factors, such as the local population and the spread of the houses. The following sections discuss these configurations and their processes in further detail.

\subsection{1: Individual DC House Configuration}

In the Individual DC house configuration, a single DC house operates in islanding mode, as illustrated in Figure 2-8 [20]. This type of configuration is suitable for villages with widely disperse population and it can have one or multiple renewable sources generating DC power. In order to have regulated input into the Multiple Inputs DC-DC converter (MISO), the renewable sources are followed by the DC-DC converter. This MISO conversion translates to a single DC bus voltage at $48 \mathrm{~V}$ which is used to power the house and charge the battery bank for the night-time use. The completed DC house projects under this configuration are discussed in the next section. 


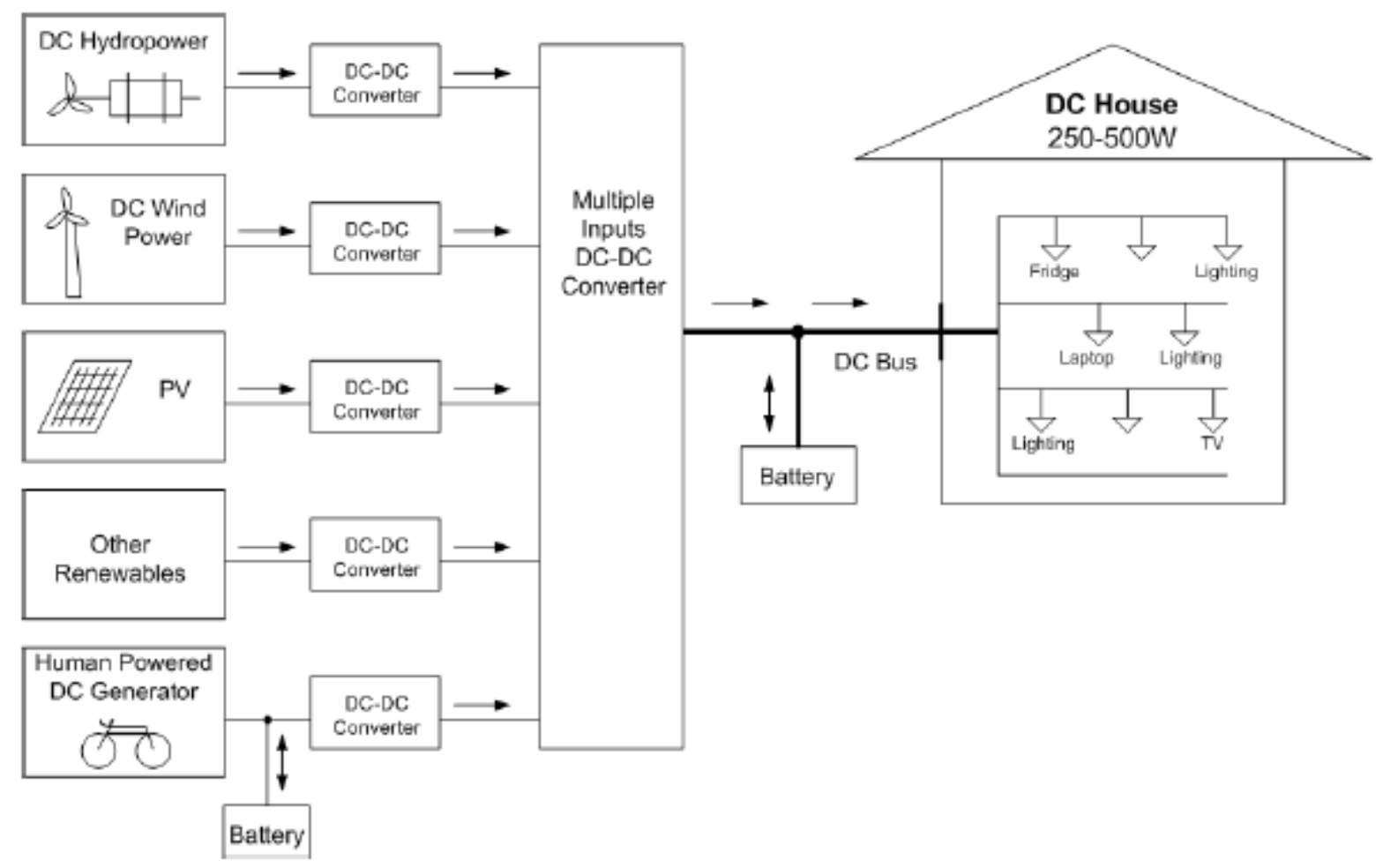

Figure 2-8: Single DC house Configuration [20]

In [14] a bicycle power generator was designed and implemented. The goal was to have a cost effective human-powered DC generator which could be used in times when other renewable sources would not be generating power. A car's alternator, with modified internal wiring, was attached to the bike's back tire in order to convert the mechanical energy into electrical energy. As Figure 2-8 illustrates, this electrical energy then could be used to provide power straight to the DC house or charge the batteries. The findings of the study showed that the alternator's efficiency to convert mechanical energy to electrical energy is highly dependent on its RPM in conjunction with its internal resistance. At around 1800 RPM, the alternator's efficiency was close to $35 \%$. It was also 
concluded that there is plenty of room for improvements in the lower RPM efficiency. Other projects focused on additional renewable sources such as wind power [18] and hydro-electric [19].

In [8] the main DC bus voltage feeding to the house was analyzed for the highest efficiency. The goal of the project was to determine the adequate DC bus voltage that would generate the highest system efficiency. It accounted for variables such as mesh and radial distribution systems, wire size, different loads, and 500W maximum power input. Subsequently, it was concluded that $48 \mathrm{~V}$ bus would give the best results in efficiency and cost of the components [8].

In [9] research was conducted on available DC loads that can be used in the DC house. A system was designed, modeled, and characterized in steady state using Simulink toolbox in MATLAB. The selection strategy for the loads were mainly based on fulfilling the basic humanitarian needs of daily life such as lighting, cooking appliances, and food storage. Further detailed study was conducted on the individual loads to determine the best available option in the market, given the capabilities and limitation of DC house. For example, two types of compressors were studied for the refrigerator load. It was determined a conventional compressor would not be a good choice of load for the DC house because it typically requires large amount of start-up current which would exceed the capabilities of the source given that most of the renewable sources are constant current source. An alternative swing-compressor available in the market was determined a better fit because it requires a low startup current. Based on these findings, a refrigerator available in the market was selected and further studied by creating a model 
in Simulink based on the characteristics given in the datasheet. To maximize efficiency, and simultaneously reduce the cost of the system, different circuit configurations were studied to connect the loads within the DC house while varying the feeder bus voltages and size of wire used for the circuit [9].

In [4] an economical and energy-efficient DC light bulb was designed and implemented. This DC Light Bulb was to operate at input voltage ranging from 24 VDC to 72 VDC as shown in Figure 2-9. Test in the lab showed the DC light bulb is capable of producing illumination intensities equivalent to a standard 100W A19 incandescent light bulb at one-tenth the total power consumption. This study demonstrated the feasibility of the DC Light Bulb in terms of overall efficiency, line regulation, load regulation, power consumption, total lumens, and thermal profile.

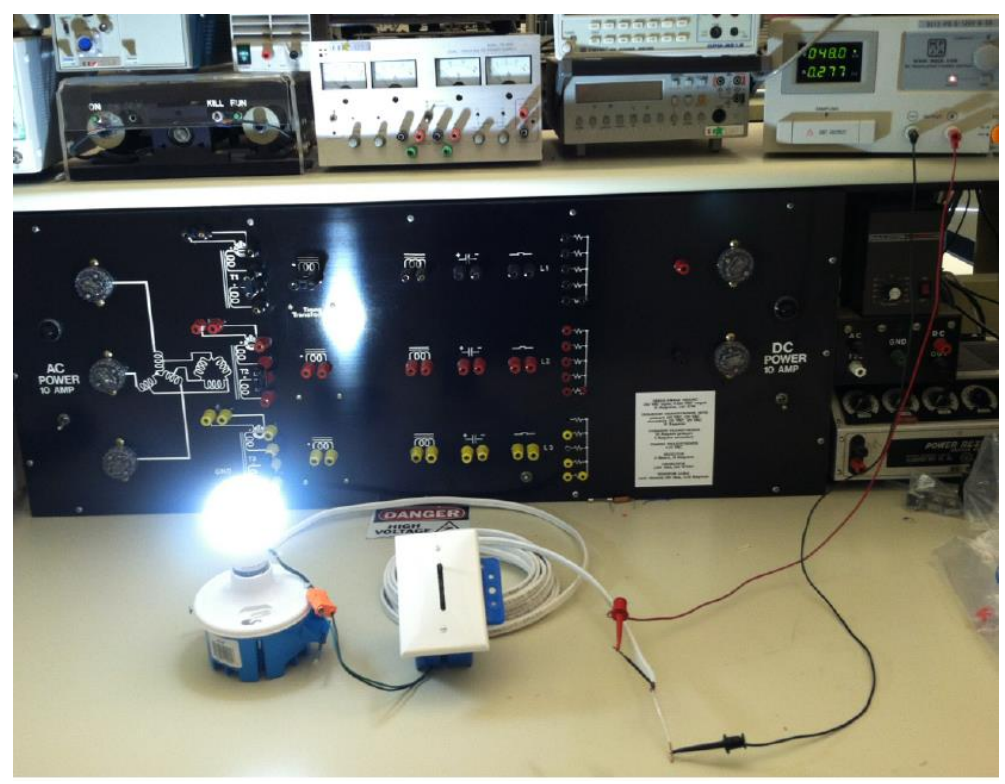

Figure 2-9: Fully DC Light bulb at full load from 48 VDC input [4] 
In [16] Multiple-Input and single output DC-DC converter was studied to integrate multiple renewable energy sources for a single DC house as illustrated in Figure 2-8. Full bridge topology was chosen because only one winding per input source in the transformer is required, which helps to keep the transformer size small. The controller is sensing current at the primary winding and voltage at the output to auto adjusts its PWM duty cycle. Figure 2-10 illustrates a prototype board that was built and tested in the lab. The design had three different inputs and single output with a maximum of 80 Watts of output power capability. The MISO board design was further improved in [17] which increased its power capability to $150 \mathrm{~W}$. The $500 \mathrm{~W}$ requirement for a single DC house can be met by having multiple converters in parallel configuration.

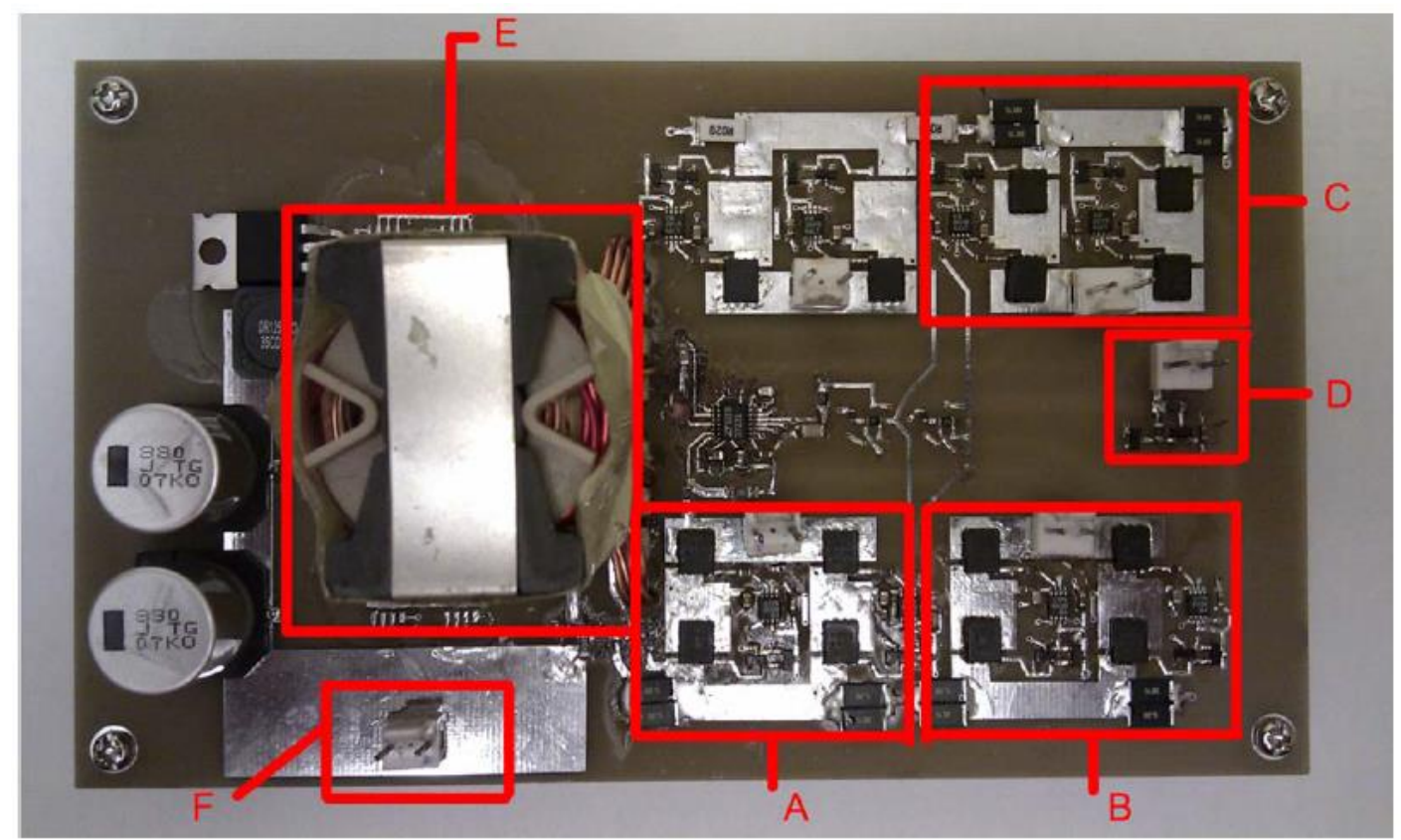

Figure 2-10: Multiple Input Single Output board [16] 


\subsection{2: Multiple DC Houses Configuration}

Second configuration of the DC house is illustrated in Figure 2-11 [20]. This configuration allows the exchange of power in a small cluster of DC houses. It is suitable for more concentrated pockets of remote villages. Flexibility of sharing power further improves the reliability of the system because there are fewer chances of power outages, in case the renewable sources for one house stop working.

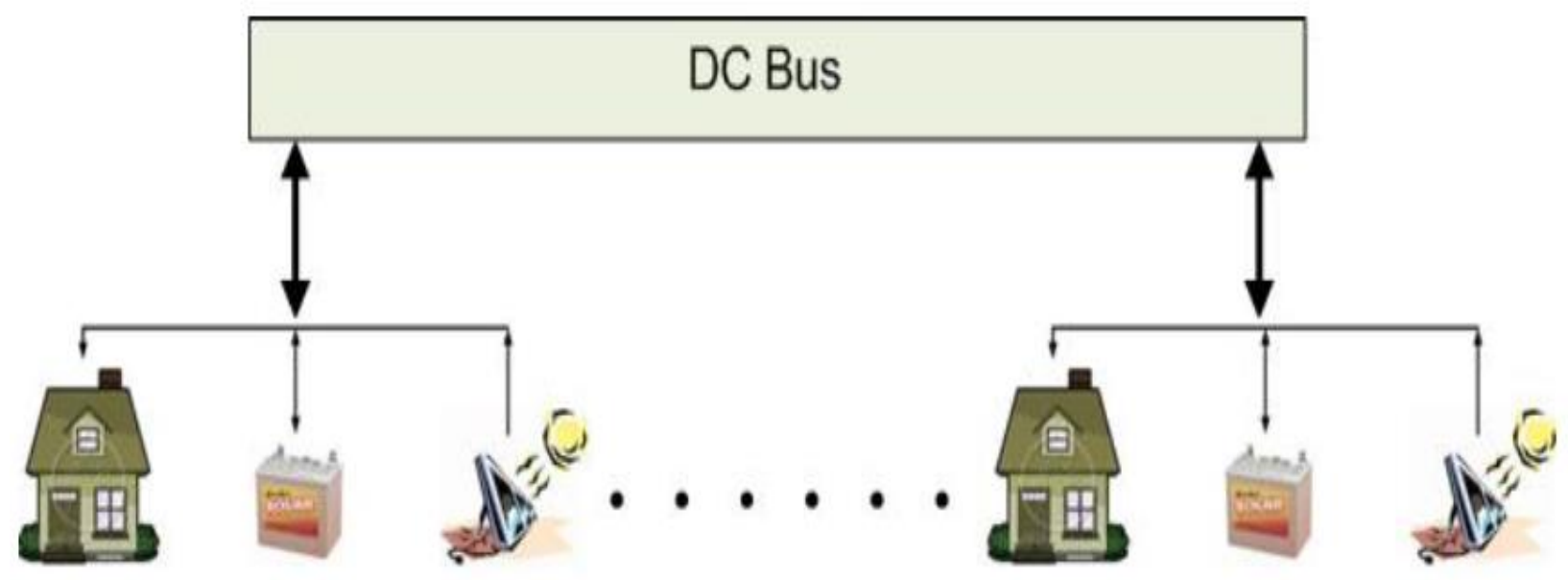

Figure 2-11. Multiple DC houses configuration [20] 


\subsection{3: Centralized Distribution Network for DC Houses}

The third configuration for the DC house project is a centralized distribution network illustrated in Figure 2-12 [20]. This configuration can be implemented in a small clustered village with ten or more houses. This approach offers betters system reliability, yet lowers the cost of the project. This thesis focuses on the design, modeling, simulation, and performance evaluation of this centralized distribution network, which will be presented in greater detail in the following chapters.

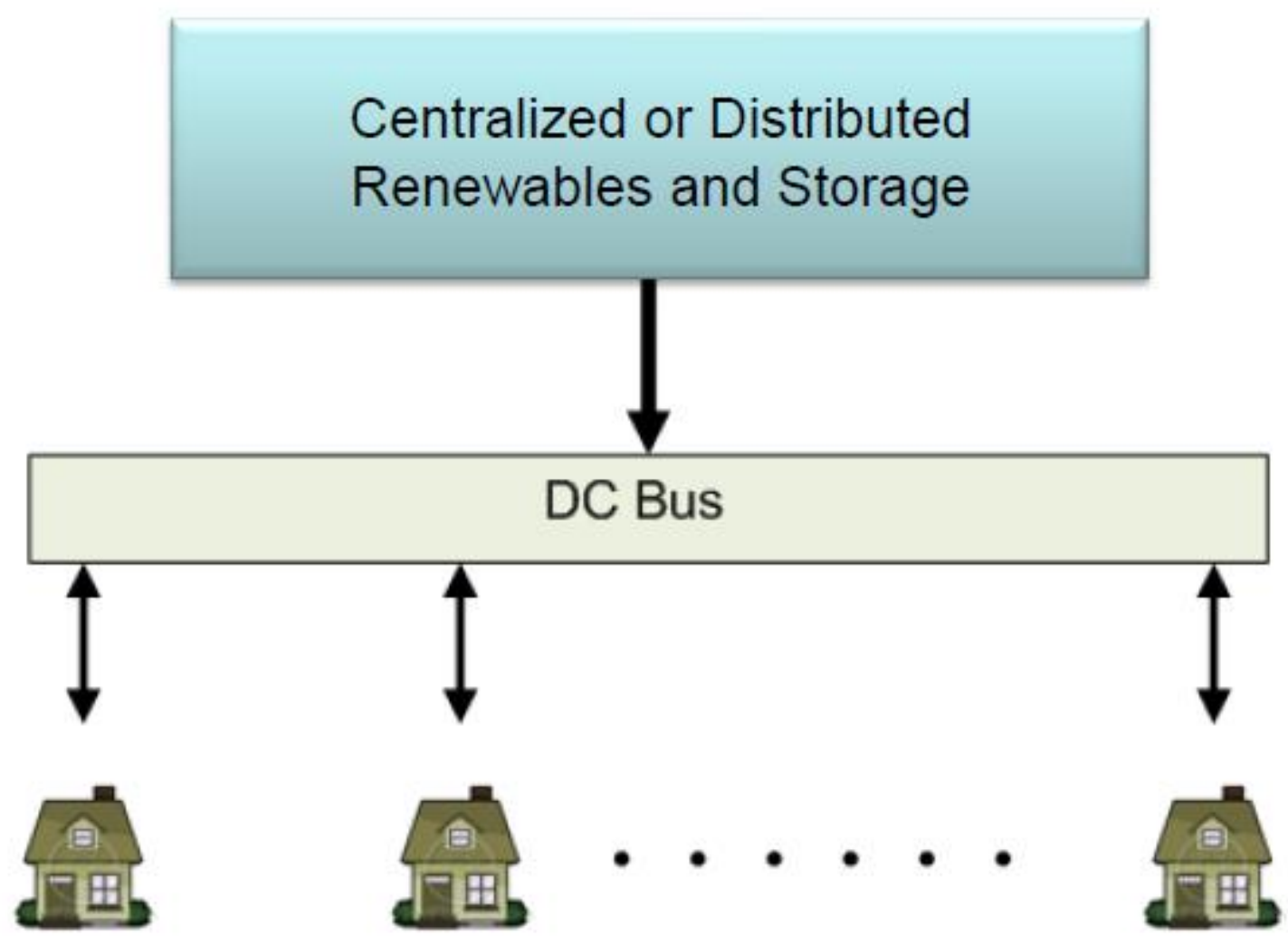

Figure 2-12: Centralized distribution network for dc houses [20] 


\section{CHAPTER 3}

\section{System Design}

\section{1: PSCAD Software}

The electric grid has remained unaffected since the 20th century's technological advancements. But the recent integration of power electronics and communication devices into the grid is changing this hundred-year-old infrastructure into a smarter grid. In the so-called "Smart Grid" infrastructure, energy would be generated, distributed and used more efficiently. However these new power electronic and communication devices pose problems for most of the existing power system design software because the scope of their capabilities to simulate behavior of these new electronic devices is very limited. These simulation challenges are resolved by using Power System Computer Aided Design (PSCAD) software package developed by Manitoba HVDC Research Center. The PSCAD simulation tool can duplicate the response of power electronic devices in time steps ranging from nanoseconds to seconds [31]. Other power electronic simulation software packages, such as PSpice, are general purpose analog and mixed-signal simulator used to verify circuit design and to predict circuit behavior. Whereas, PSCAD is specifically targeted to simulate power systems and power electronic circuits [31]. Since the simulation model of the Centralized DC House Distribution Network will have power systems and power electronic components, 
PSCAD was chosen as the best available option to simulate the behavior of the centralized DC house distribution network.

\section{2: High Level System Design}

The centralized DC House distribution network is a solution to provide electricity to rural and isolated populations with low cost and high system reliability. As mentioned in the previous chapter, multiple renewable sources can be used to generate power for the DC house as well. But this study only focuses on solar power generation as the source of power for the centralized DC House distribution network. Figure 3-1 illustrates the fundamental block diagram of the proposed design for the centralized DC House distribution network.

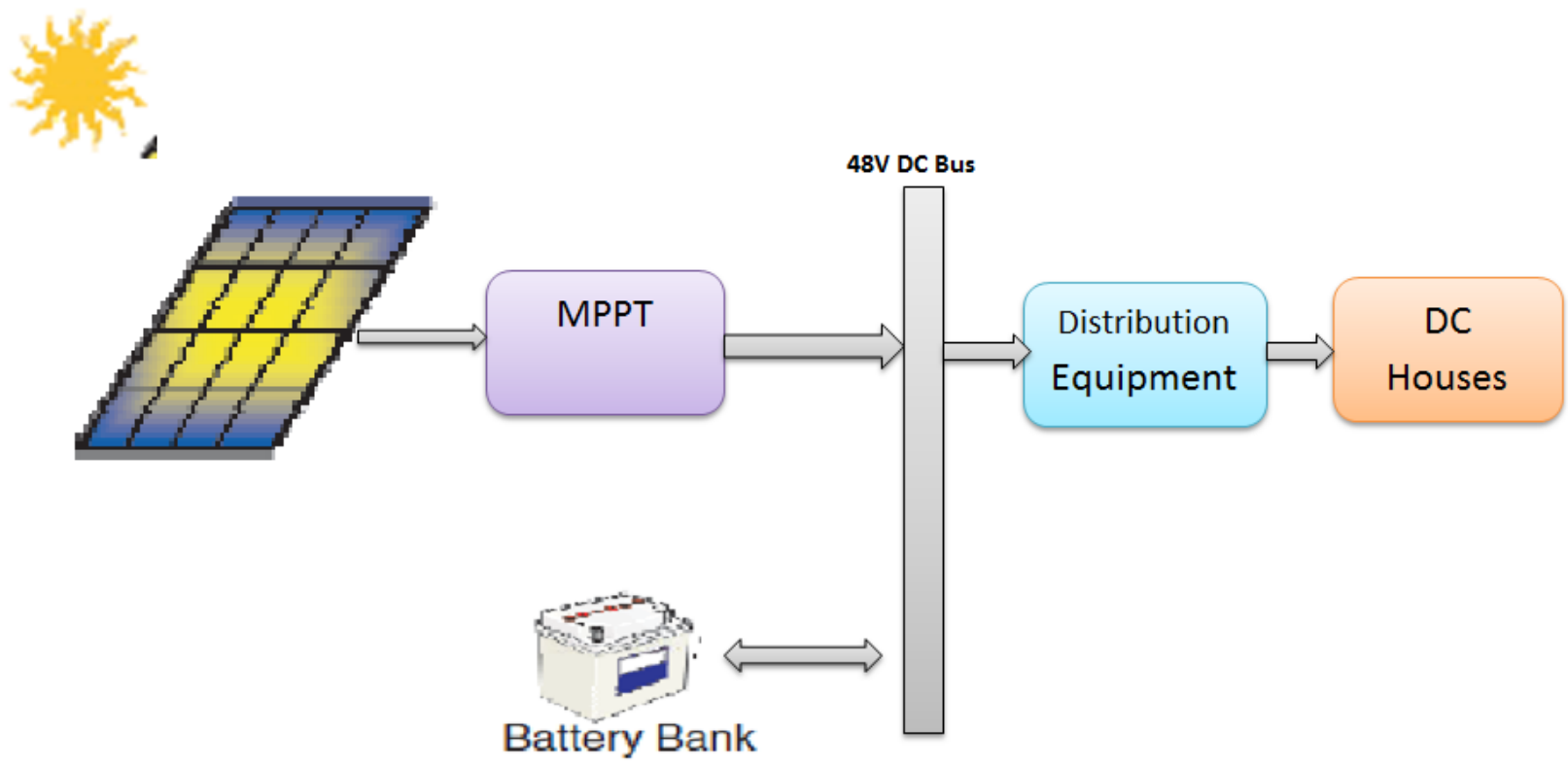

Figure 3-1: Basic block diagram of proposed design 
The power generated by PV array varies according to the solar irradiance, temperature, and load demand. These three variables control the voltage operating point of the PV array, which determines the amount of power generated. A Maximum Power Point Tracking device is used to keep the voltage operating point of the PV array around the knee of the I-V curve, which extracts maximum amount of power. Battery bank stores the excess power generated during the peak sunlight hours, and supplies it to the load at night or in cloudy weather conditions.

Figure 3-2 illustrates further a detailed block diagram of the proposed system design. PV array is a constant current source and the main requirement of any switch mode DC-DC converter used in the MPPT scheme is for it to have low input current ripple. Buck Converter or its derived topologies has a switch at the input which leads to higher input current ripple and requires a big capacitor at the input. On the other hand, the input current for a Boost Converter is continuous due to the inductor at the input. Therefore, Boost Converter topology is a better choice for the MPPT scheme. The second DC-DC converter in the system needs to convert the varying output voltage of the Boost Converter to a stable 48V DC bus distribution voltage. Additionally this converter must have low output current ripple, so smooth power is delivered to the DC bus. The Buck Converter topology fulfills both of these requirements. It has low output current ripple due to the inductor at its output. The following sections will discuss each component operation in further detail. 


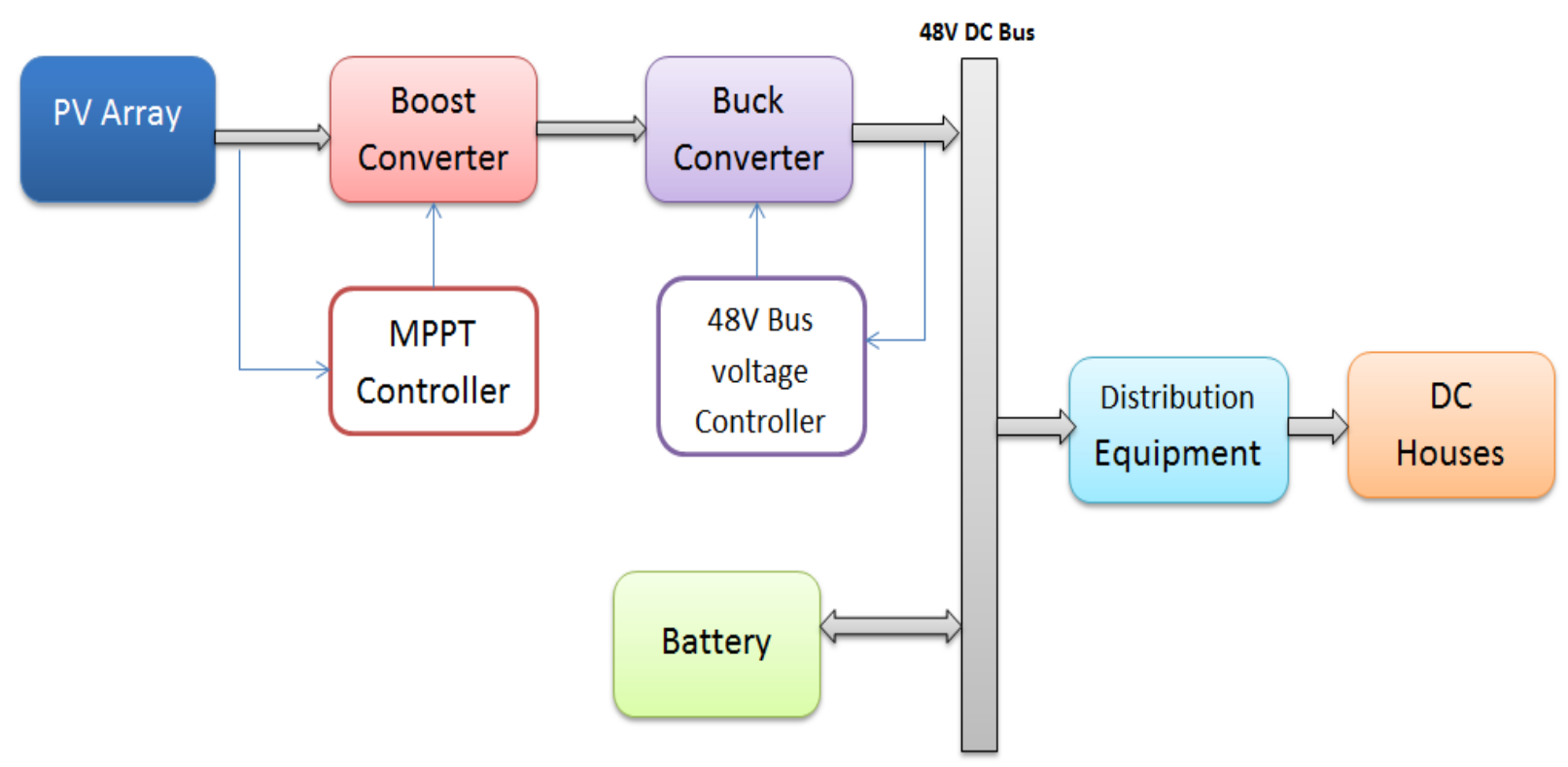

Figure 3-2: Detailed block diagram of the proposed design

\section{3: $\quad$ PV Cell Circuit Model}

The electrical equivalent model of PV cell is shown in Figure 3-3. This model contains a current source anti-parallel with a diode, a shunt resistance and a series resistance [28]. PV cells consist of silicon p-n junction which releases electrons when exposed to light. These electrons are then free to move across the junction in closed circuit loop due to the voltage potential $\mathrm{V}_{\mathrm{d}}$. This phenomenon is modeled by the light generated current source $\mathrm{I}_{\mathrm{ph}}$ in the equivalent circuit. The diode in the equivalent circuit corresponds to the silicon p-n junction characteristics. Without the sunlight, PV cell does not produce power; instead it works as a diode i.e. a p-n junction. The resistor $\mathrm{R}_{\mathrm{sh}}$ represents the leakage current, and $R_{\mathrm{S}}$ represents the connection losses and is usually not significant [21]. 


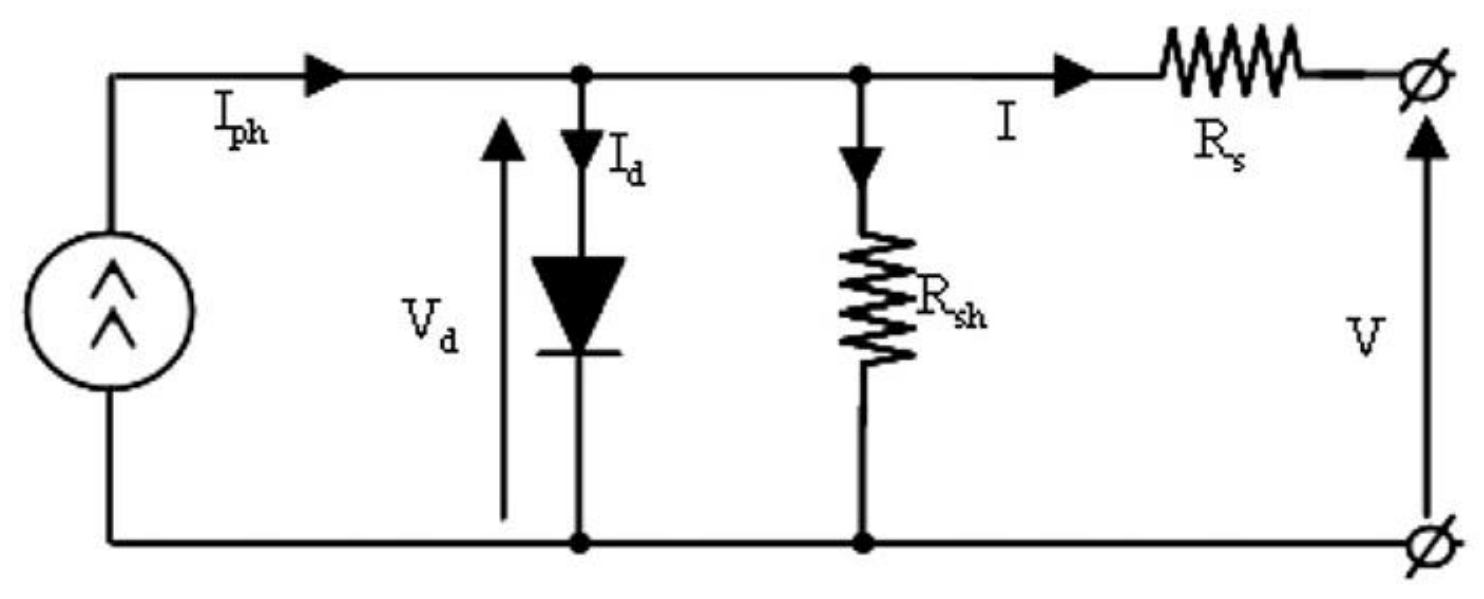

Figure 3-3: PV Cell Equivalent Circuit [28]

The output current of the current source is directly proportional to the light falling on the cell. The photon generated current source Iph is defined as:

$$
I_{p h}=\left[I_{S C}+k_{1}(T-298)\right]\left(\frac{G}{k_{2}}\right)
$$

where:

$$
\begin{aligned}
& \mathrm{k}_{1}=0.00017 \mathrm{~A} /{ }^{\circ} \mathrm{C} \text { Cells' short-circuit temperature }\left(\mathrm{A} /{ }^{\circ} \mathrm{C}\right) \\
& \mathrm{I}_{\mathrm{SC}}=\text { Cell short-circuit current at } 25^{\circ} \mathrm{C}\left({ }^{\circ} \mathrm{C}\right) \\
& \mathrm{T}=\text { Cell temperature }\left({ }^{\circ} \mathrm{C}\right) \\
& \mathrm{G}=\text { Solar radiation }\left(\mathrm{W} / \mathrm{m}^{2}\right) \\
& \mathrm{k}_{2}=1000\left(\mathrm{~W} / \mathrm{m}^{2}\right),(\text { reference Solar radiation })
\end{aligned}
$$

Figure 3-4 illustrates the non-linear characteristics of the PV cell which are mainly due to the current, $I_{d}$, flowing through the anti-parallel diode, i.e. $p$-n junction. 


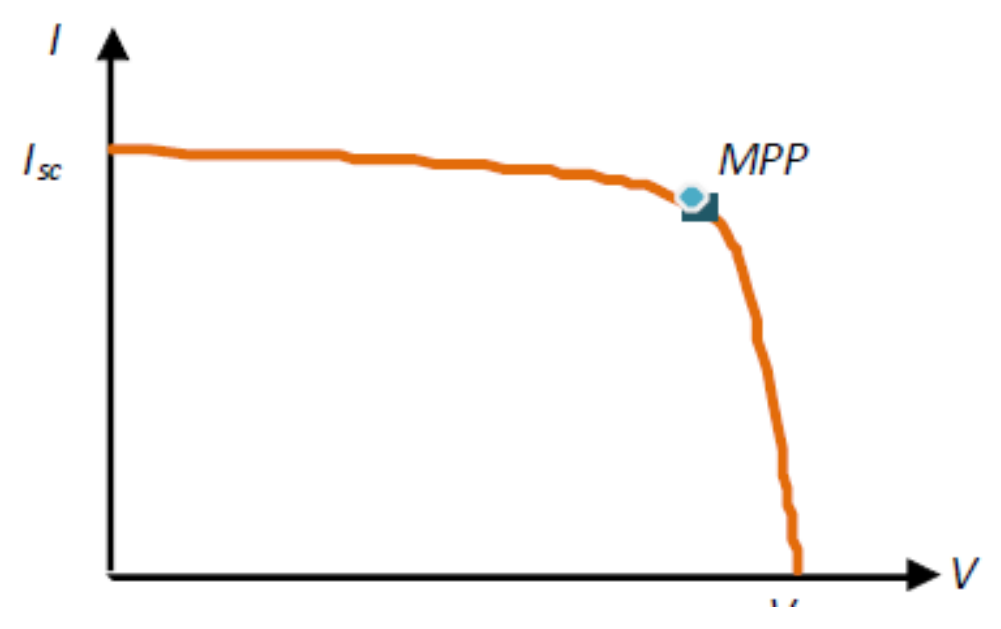

Figure 3-4: The I-V characteristics of a PV cell [21]

The basic equation to characterize the solar cell $\mathrm{I}-\mathrm{V}$ relationship is derived from analyzing the equivalent circuit in Figure 3-3. The following equation is obtained using circuit's Kirchoff's current law:

$$
I=I_{p h}-I_{d}-I_{s h}
$$

Next, the substitution of relevant expressions for the diode current $I_{d}$ and the shunt branch current $\mathrm{I}_{\text {sh }}$ provides equation 3-3:

$$
I=I_{p h}-I_{s d}\left[\exp \left(\frac{\frac{V+I R_{s}}{n k T}}{q}\right)-1\right]-\left(\frac{V+I R_{s}}{R_{s h}}\right)
$$

where:

$$
\begin{aligned}
& \mathrm{I}_{\mathrm{sd}}=\text { diode's saturation current }(\mathrm{A}) \\
& \mathrm{k}=1.3807 \times 10^{-23}, \text { Boltzmann constant, }\left(\mathrm{JK}^{-1}\right) \\
& \mathrm{q}=1.6022 \times 10^{-19}, \text { electric charge, }(\mathrm{C}) \\
& \mathrm{n}=\text { diode's quality factor }
\end{aligned}
$$


The open-circuit voltage of PV cell is obtained by letting $\mathrm{I}=0$ and $R_{s h} \rightarrow \infty$ as:

$$
V_{o c}=V_{d}-\frac{n k t}{q} \ln \left(\frac{I_{p h}}{I_{s d}}+1\right) \approx \frac{n k T}{q} \ln \left(\frac{I_{p h}}{I_{s d}}\right)
$$

Short-circuit current of the cell is obtained by applying a short at the cell's output voltage $\mathrm{V}=0$ and average current through diode is neglected, so the short circuit current ISC is stated as:

$$
I s c=\frac{I_{p h}}{1+\frac{R_{s}}{R_{s h}}} \cong I_{p h}
$$

The output power $\mathrm{P}$ of the PV cell is defined as

$$
P=V I
$$

Substituting (2) into (6) yields

$$
P=V I_{p h}-I_{s d}\left[\exp \left(\frac{q}{n k T\left(R_{s}+I\right)}\right)-1\right] V-\frac{\left(R_{s} I+V\right) V}{R_{s h}}
$$

A single solar cell is the simplest component of a PV module. The current generated by this cell is very small. Therefore a solar module is a combination of multiple solar cells that are connected in series and/or parallel to generate usable current and voltage. 


\subsection{1: PV module PSCAD Implementation}

Figure 3-5 illustrates the custom library component, available in PSCAD, to emulate PV behavior. This component was developed by Dr. Athula Rajapakse from the University of Manitoba, Canada. This module implements behavior of equation 3-3 based on temperature and irradiance inputs. Figure 3-6 illustrates the default parameters of the individual PV cell that were used in the simulation. One can obtain these parameters from PV manufacturer's data sheet, and modify them accordingly in the PSCAD to emulate the behavior of a particular PV cell that will be used.

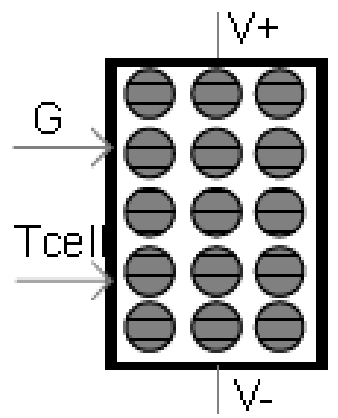

Figure 3-5: PV Module Components available in PSCAD 


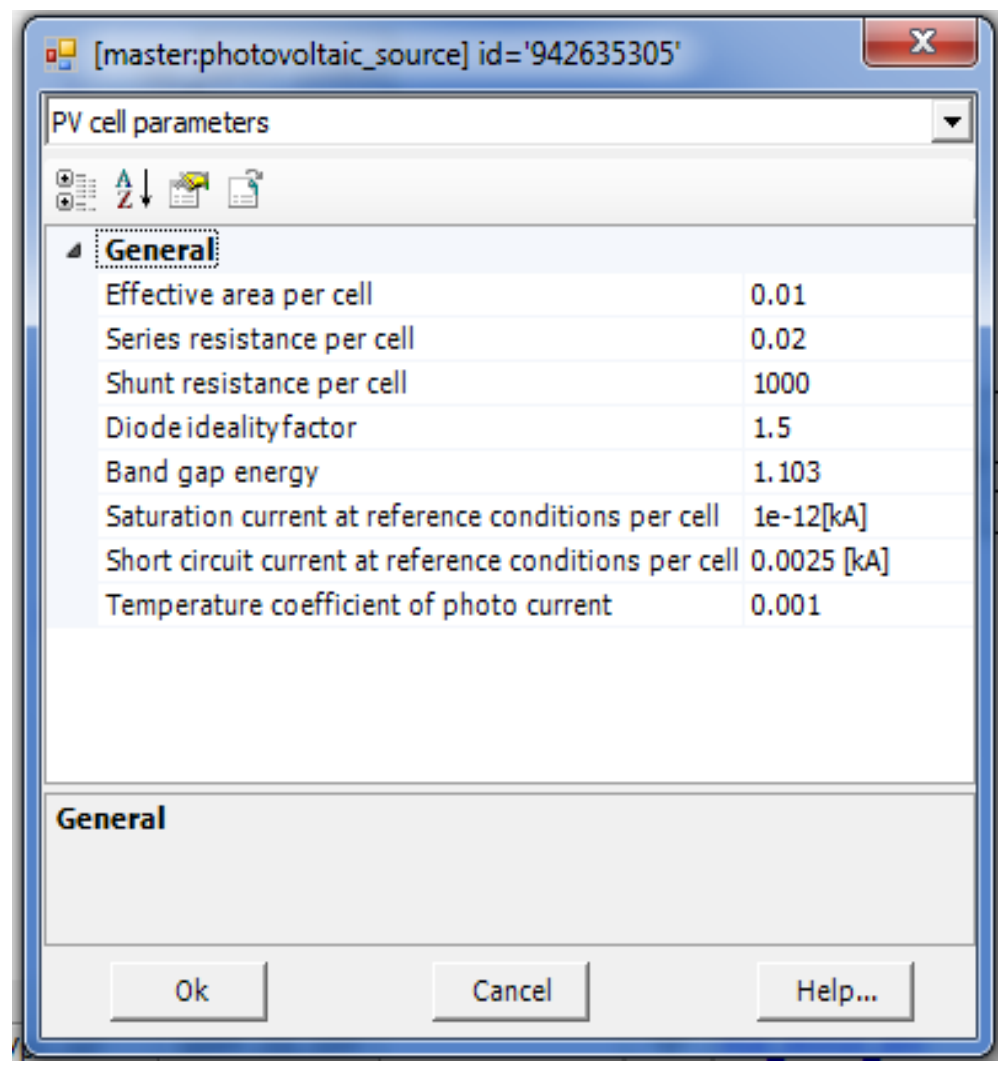

Figure 3-6: PV Cell Default Parameters

Figure 3-7 illustrates the PV array configuration used for the simulation. In the PV array parameters, one can change the number of cells in a module in series or parallel configuration as well as can configure the PV array with series or parallel connect PV modules as needed. The Standard Operating Condition (SOC) test for PV is performed at $800 \mathrm{~W} / \mathrm{m}^{2}$ and $25^{\circ} \mathrm{C}$. The SOC I-V and Power characteristics of the individual module used in the simulation are shown in Figure 3-8. The power generation of the module varies with the operating voltage and maximum power generation point occurs around the knee of the curve when module is operating around $24 \mathrm{~V}$. In this configuration $400 \mathrm{PV}$ panels are connected in parallel. A single panel could produce $45 \mathrm{~W}$ of maximum power, which means in this configuration PV array is capable of producing $18 \mathrm{~kW}$ of power. 


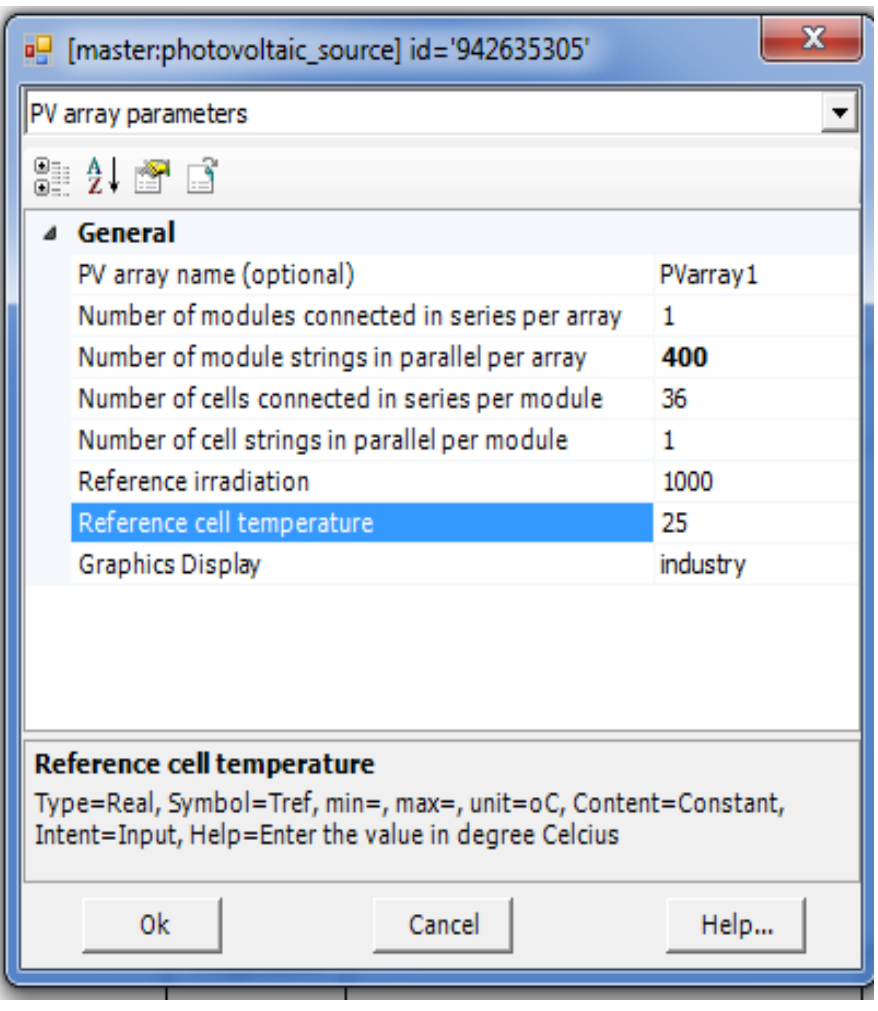

Figure 3-7: PV Module and PV Array Parameters

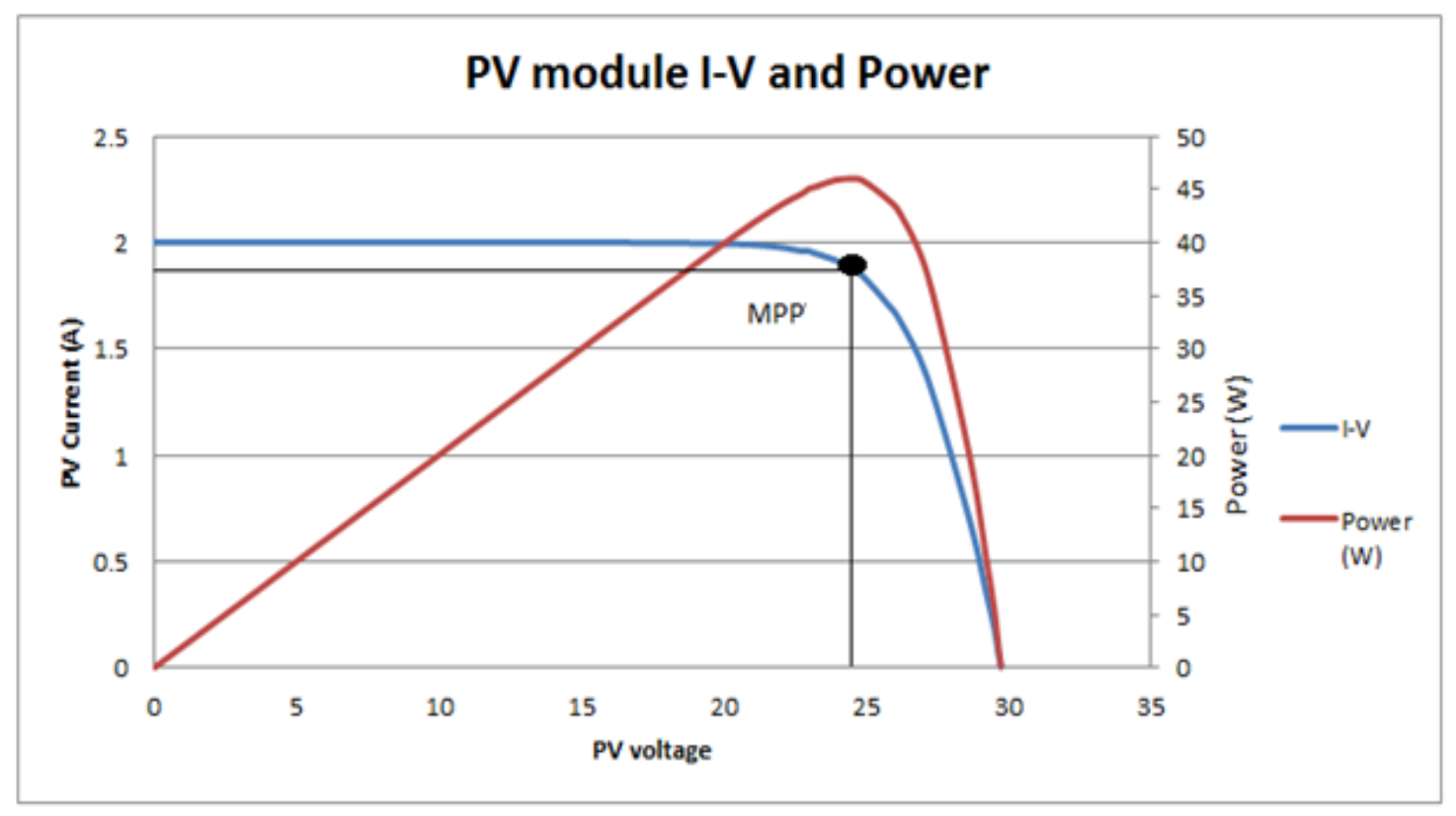

Figure 3-8: PV Module I-V and Power Characteristics 


\section{4: $\quad$ PV Maximum Power Point Tracking}

As shown in Figure 3-8, the PV power generation characteristics are non-linear, which vary with solar irradiation, temperature and load. The amount of power a PV module can generate depends on the operating point on the I-V curve. There is only one point of maximum power (MPP - Maximum Power Point), which occurs around the knee point of the curve. A maximum power point tracking device is required in order to keep the system operating on the knee of the I-V curve with the changing weather and temperature. A maximum power point tracker (MPPT) is a power electronic DC-DC converter used to obtain maximum amount of power from PV array. It uses an intelligent algorithm to ensure $\mathrm{PV}$ is always operating at the maximum power point as the solar radiation, temperature and load fluctuate. Figure 3-9 shows the custom library component available in PSCAD for MPPT. This custom component offers two peak power tracking schemes: Perturb and Observe and Incremental Conductance.
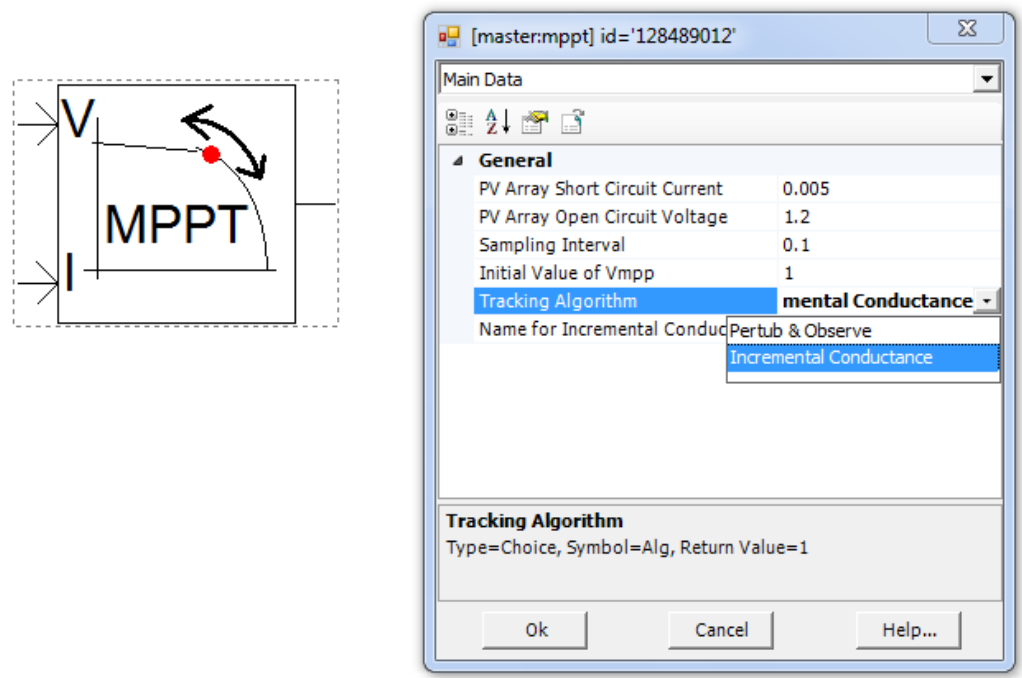

Figure 3-9: PSCAD MPPT Component (left), and Parameters (right) 
Perturb and Observe (P \& O) scheme is carried out by changing the duty cycle of the power converter connected to the PV array and observing the output power. In this case, changing the duty cycle of the power converter changes the input current from the PV array accordingly. Consequently, this changes the operating voltage of the array. Figure 3-8 shows when operating to the left of the MPP, incrementing the voltage increases the power, and when operating to the right of the MPPT, incrementing the voltage decreases the output power. Table 3-1 below summarizes the perturbation steps taken to reach maximum power point of the PV array. The table shows that if the PV output power increases after perturbation, then the subsequent perturbation is kept the same; but if the output power decreases after perturbation, then the previous perturbation should be reversed. The down side of this periodic process is that the system oscillates about the MPP. This oscillation can be reduced using smaller perturbation size, which however slows down the MPPT process [30].

Table 3-4: Summary of Perturb \& Observe Algorithm

\begin{tabular}{|c|c|c|}
\hline Perturbation & Change in Power & Next Perturbation \\
\hline Positive & Positive & Positive \\
\hline Positive & Negative & Negative \\
\hline Negative & Positive & Negative \\
\hline Negative & Negative & Positive \\
\hline
\end{tabular}

The next maximum power point tracking scheme available in the PSCAD MPPT component is the Incremental Conductance method. This scheme focuses on the slope of 
the PV array power curve. The slope of the PV array power curve is zero at the MPP, positive on the left of the MPP and negative on the right, as given by:

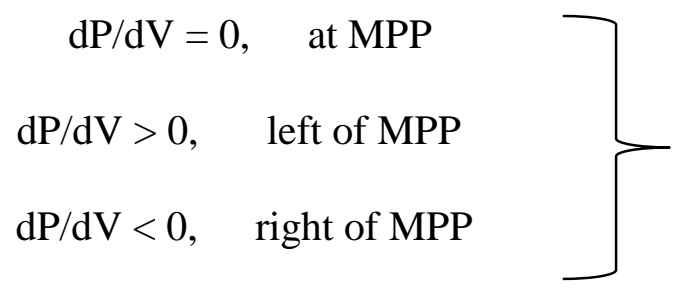

Since

$$
\frac{d P}{d V}=\frac{d(I V)}{d V}=I+V \frac{d I}{d V} \cong I+V \frac{\Delta I}{\Delta V}
$$

Equation 3-8 can be rewritten as:

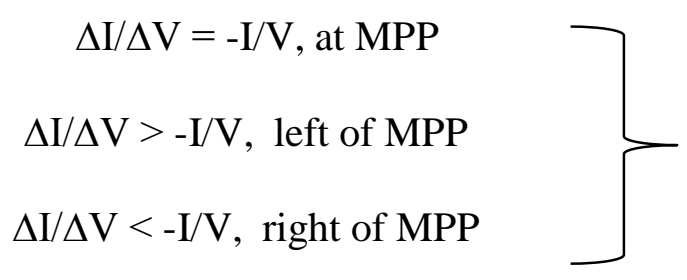

Therefore, MPP can be tracked by comparing the instantaneous conductance (I/V) with the incremental conductance $(\Delta \mathrm{I} / \Delta \mathrm{V})$. Figure 3-10 illustrates the incremental conductance base algorithm used by the PSCAD MPPT component. The operating point of the PV array is Vref which is equal to Vmpp at MPP. Once MPP has been reached, the PV array is maintained at this point unless a change in $\Delta \mathrm{I}$ is noted. No oscillation around the MPP point is the advantage incremental conductance has over $\mathrm{P} \& \mathrm{O}$ algorithm. 


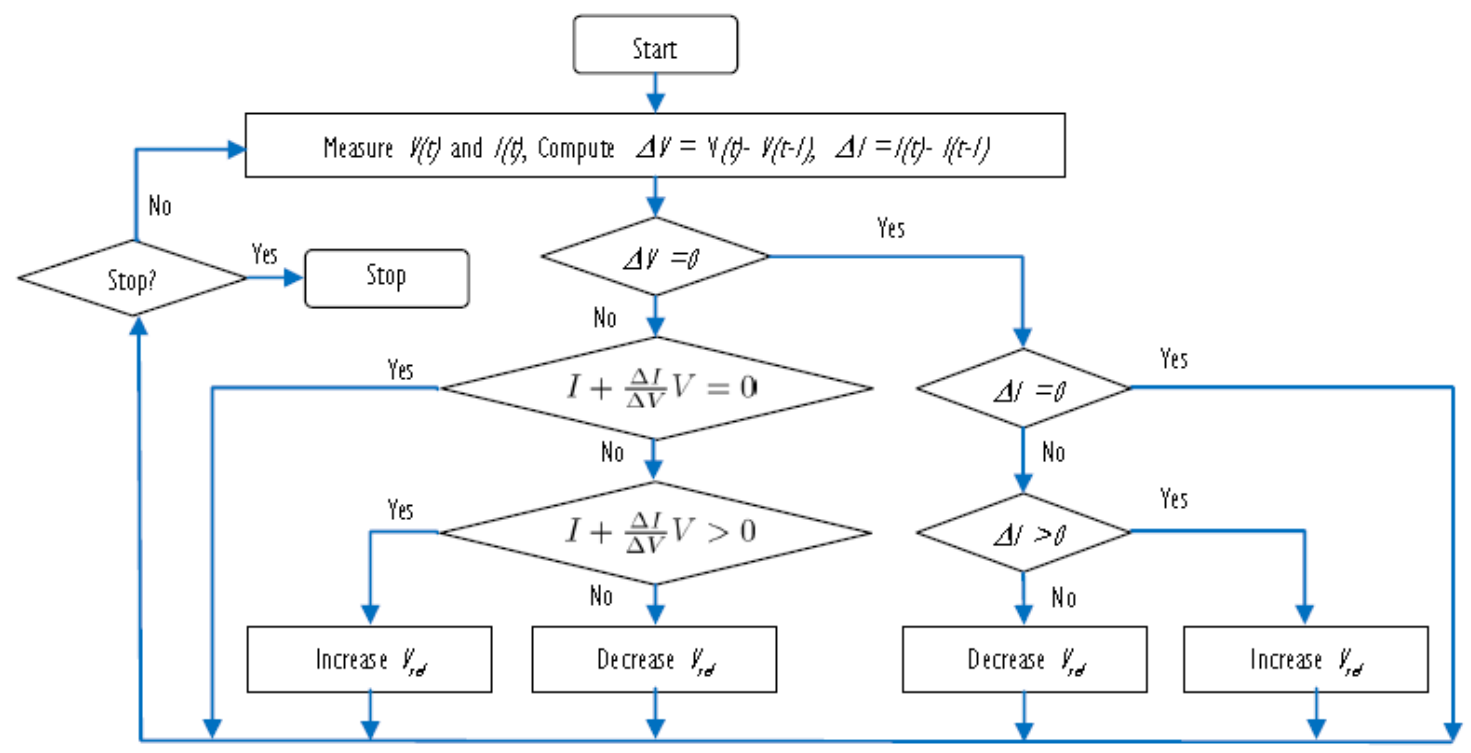

Figure 3-10: Incremental Conductance Based Algorithm MPPT [30]

The PI controller used to drive the DC-DC converter for maximum power point tracking is illustrated in Figure 3-11. Instantaneous PV array voltage and current are measured to calculate the optimum operating voltage point (Vmpp) of the PV array which generates the maximum power. 


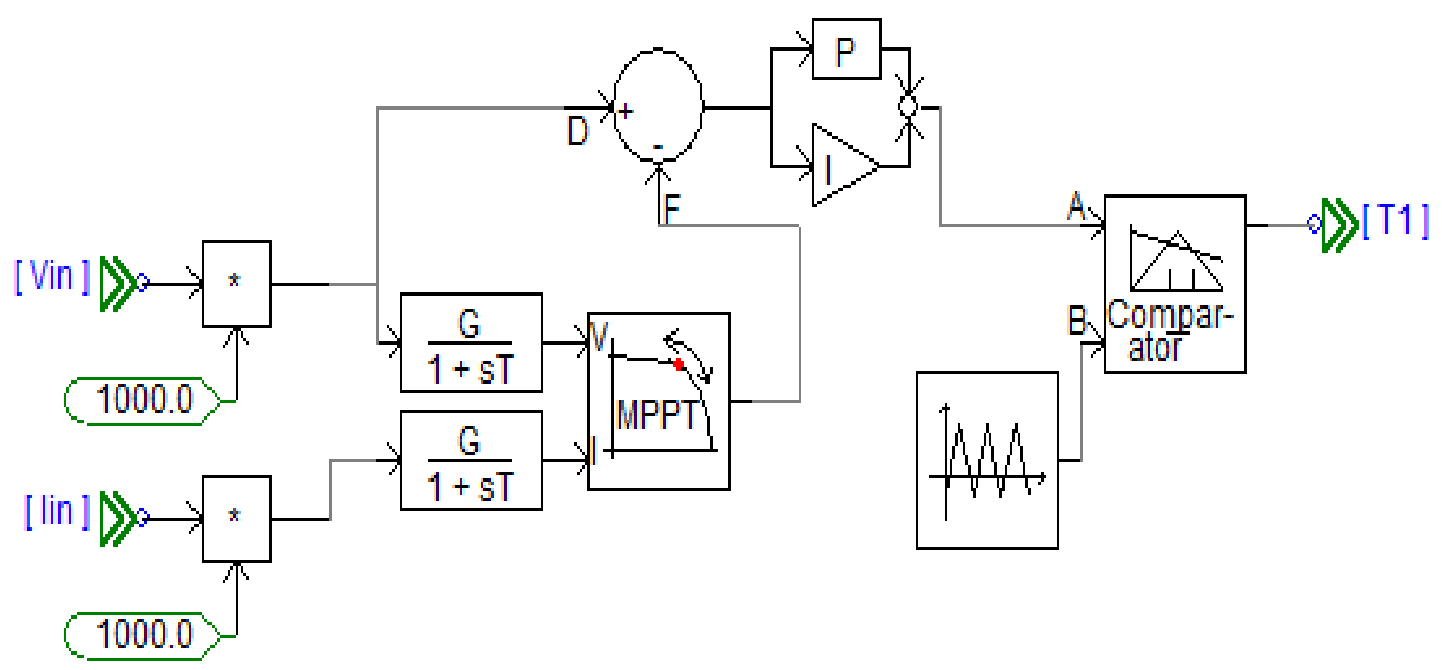

Figure 3-11: The Controller used to drive the Boost Converter Switch for MPPT

\section{5: Boost Converter Operation}

Figure 3-12 illustrates the basic block diagram of the Boost Converter. DC-DC converters can operate in three conduction modes: Continuous Conduction Mode (CCM), Discontinuous Conduction Mode (DCM), and Boundary Conduction Mode (BCM) [32]. In Continuous Conduction Mode, the inductor current remains positive throughout the switching period. In Discontinuous Conduction Mode, the inductor current reaches zero for portion of the switching period. In Boundary Conduction Mode, the inductor current is at the edge of the CCM before going to the DCM (special case of CCM). Figure 3-13 illustrates the three different conduction modes of the DC-DC converters. Since the Boost Converter will be connected to the PV array (constant current source), the desired mode of operation for the converter is the Continuous Conduction Mode. 


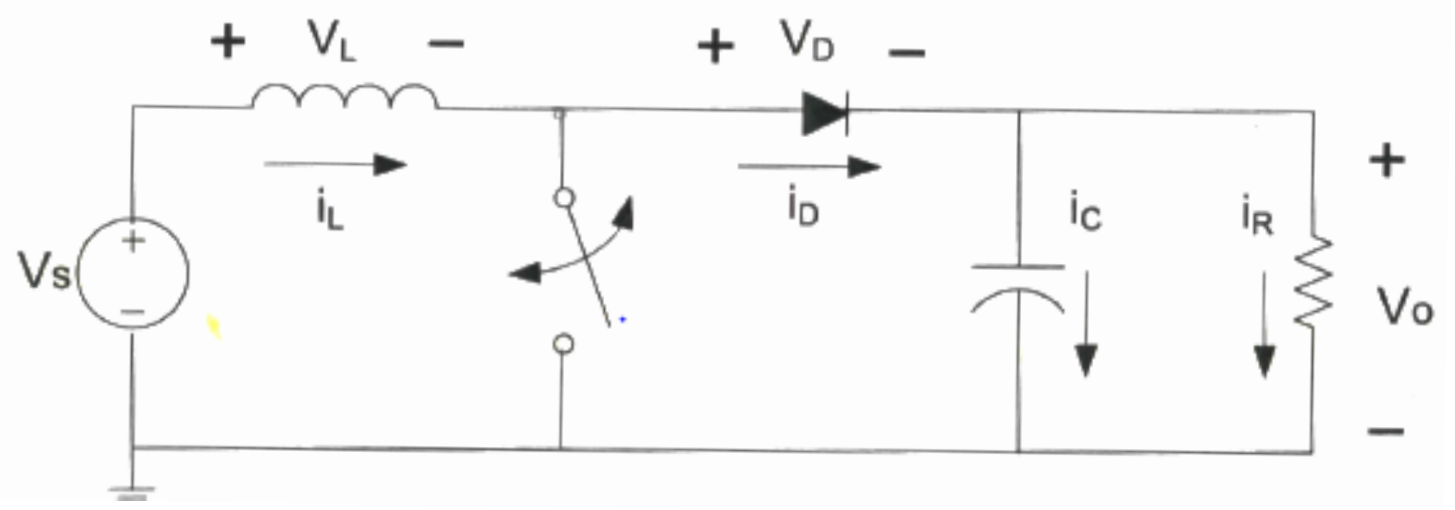

Figure 3-12: Boost Converter Block Diagram [32]

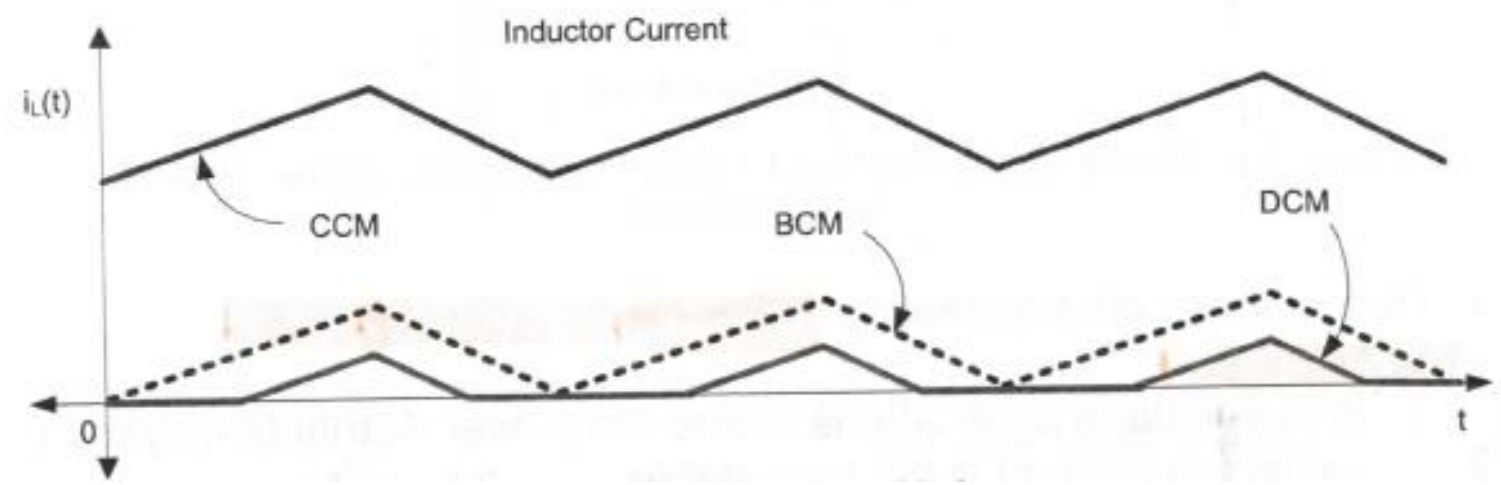

Figure 3-13: Conduction Modes of DC-DC Converters [32]

In the CCM mode, boost converter has two states per switching cycle. During the switch ON state (Figure 3-14), switch is forward biased and diode is reversed biased. The current flows through the inductor in clockwise direction and the inductor stores energy in its magnetic field. The polarity on the left side of the inductor is positive during this state (storing energy). During the switch OFF state (Figure 3-15), switch is open, and 
diode is forward biased, which increases the impedance of the circuit. Consequently the inductor resists the change in the circuit current due to higher impedance; thus the polarity of the inductor is reversed (positive polarity on the right side of the inductor). As a result two sources in series supply the load at higher voltage and charge the output capacitor simultaneously. Also the output capacitor is sized to supply sufficient power to the load during the switch OFF state [33].

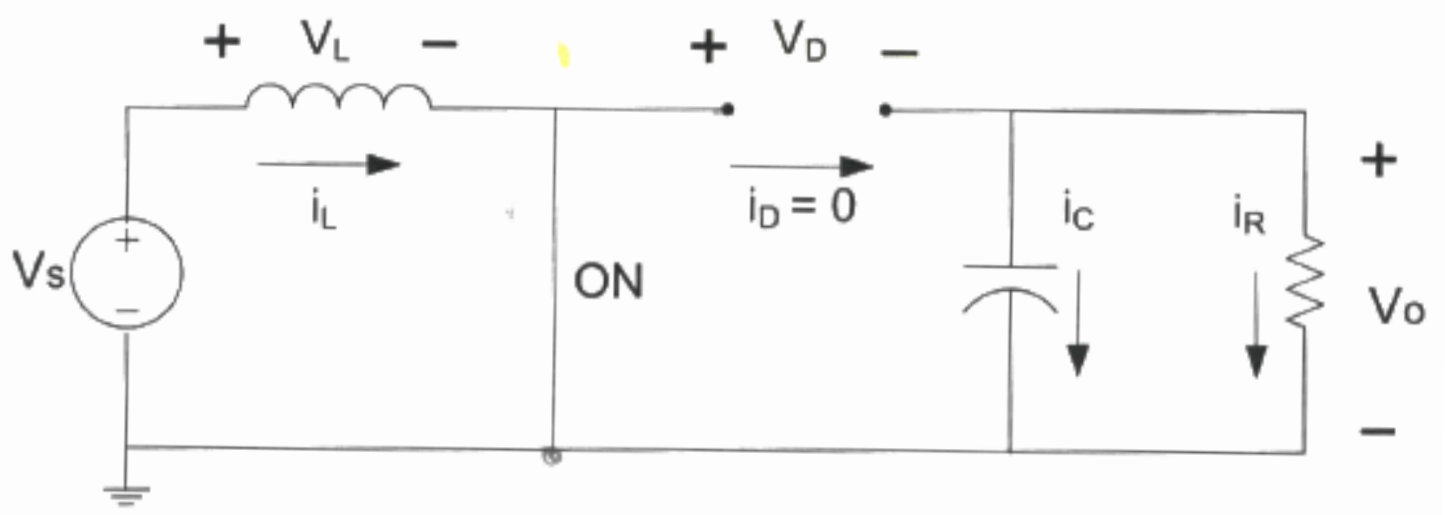

Figure 3-14: Boost Converter CCM Switch ON State [32]

The voltage across the inductor during switch ON state can be written as:

$$
V_{L}=V_{S}=L \frac{d_{i_{L}}}{d t} \text { or } \frac{d_{i_{L}}}{d t}=\frac{V_{S}}{L}
$$

The increasing inductor current during the switch $\mathrm{ON}$ state is given by:

$$
\frac{d_{i_{L}}}{d t}=\frac{\Delta i_{L}}{\Delta t}=\frac{\Delta i_{L}}{D T}=\frac{V_{S}}{L}
$$




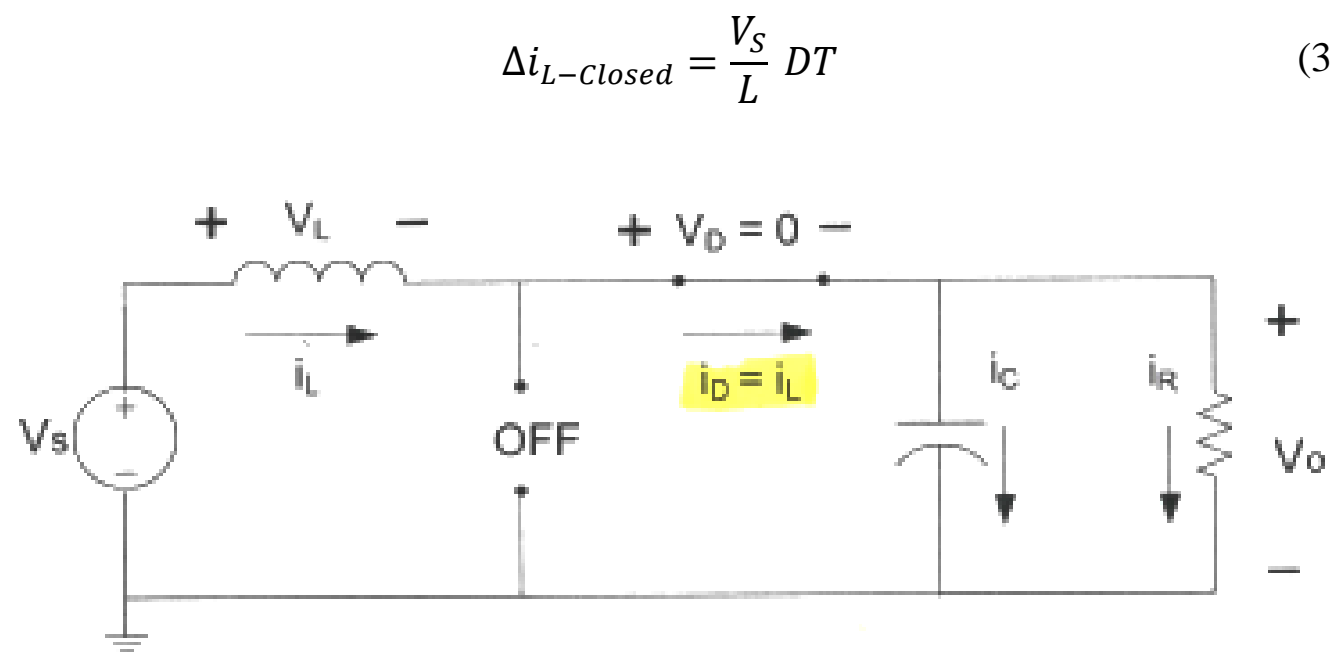

Figure 3-15: Boost Converter CCM Switch OFF State [32]

The voltage across the inductor during switch OFF is calculated as:

$$
\begin{gathered}
V_{L}=V s-V_{O} \\
V_{L}=L \frac{d i_{L}}{d t} \text { or } \frac{d i_{L}}{d t}=\frac{V_{S}-V_{O}}{L}
\end{gathered}
$$

The change in the inductor current is computed as:

$$
\begin{gathered}
\frac{d i_{L}}{d t}=\frac{\Delta i_{L}}{\Delta t}=\frac{\Delta i_{L}}{(1-D) T}=\frac{V_{S}-V_{O}}{L} \\
\Delta i_{L-\text { open }}=\frac{\left(V_{S}-V_{O}\right)(1-D) T}{L}
\end{gathered}
$$


As stated earlier, in steady state conditions the change, when inductor current is increasing (switch ON) and decreasing (Switch OFF), are equal. This implies that the net change in inductor current over one period is zero. Therefore in CCM mode the output voltage of the Boost Converter can be equated to:

$$
\begin{gathered}
\Delta i_{L-\text { Closed }}+\Delta i_{L-\text { open }}=0 \\
\frac{V_{S} D T}{L}+\frac{\left(V_{S}-V_{O}\right)(1-D) T}{L}=0 \\
\overline{V_{O}}=\frac{V_{S}}{1-D}
\end{gathered}
$$

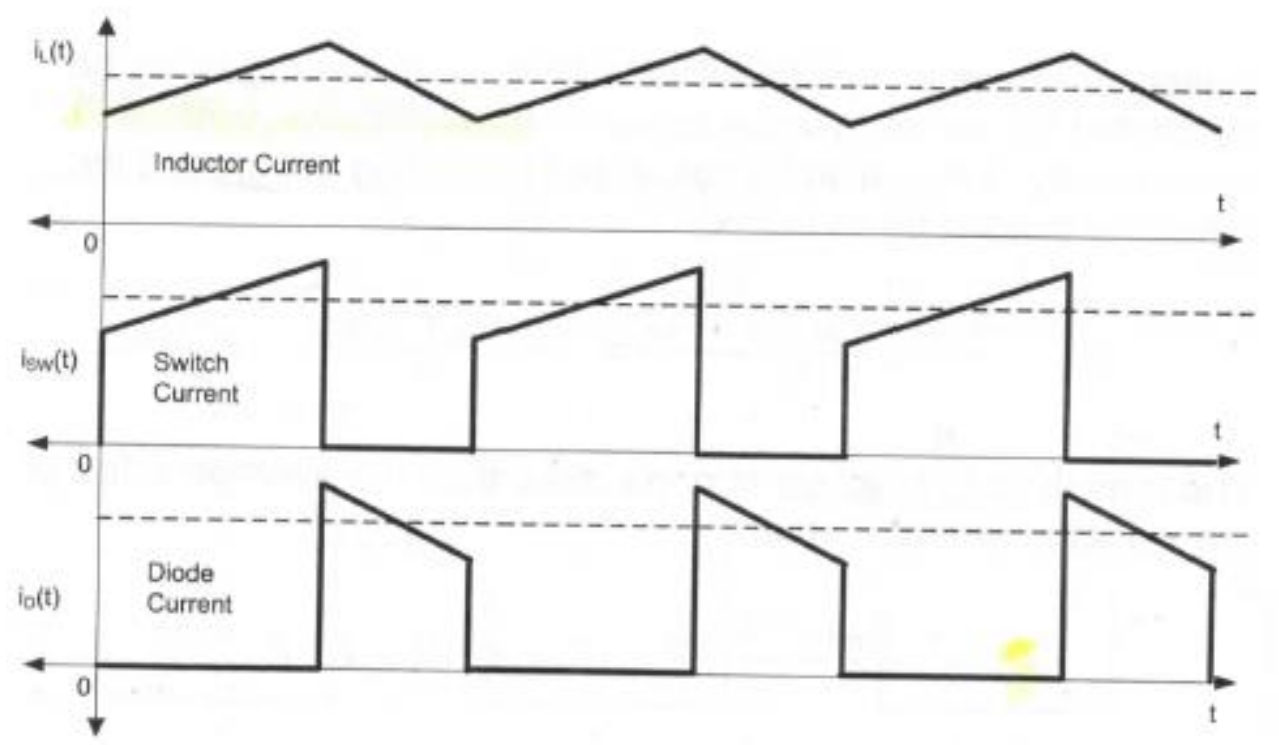

Figure 3-16: Boost Converter Inductor, Switch and Diode Current [32]

The Boost Converter waveforms in CCM are illustrated in Figure 3-16. The waveform $I_{S w(t)}$ represents, the current through the switch during $T_{O N}$, and waveform $I_{D(t)}$

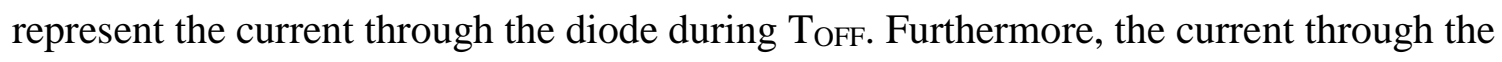
inductor $\mathrm{I}_{\mathrm{L}(\mathrm{t})}$ is equal to the combination of the switch and diode currents. 


\subsection{1: Boost Converter PSCAD Implementation}

Figure 3-17 illustrates the block diagram of Boost Converter implemented in PSCAD. An input capacitor is used for a stable voltage input from the PV array. The duty cycle of the switch is controlled by the MPPT controller shown in Figure 3-11. The MPPT varies the duty cycle according to the solar irradiance, temperature and load conditions in order to extract maximum power out of the PV array. The switching frequency of the DC-DC converter can be selected from a range starting at $5 \mathrm{kHz}$ to over $100 \mathrm{kHz}$. A higher switching frequency requires smaller energy storage components (inductor and capacitor), which makes the converter compact. However, the trade-off is that the simulation runs very slow because of the lower time step required by high switching frequency. As a result, switching frequency of $20 \mathrm{kHz}$ was selected to keep the balance between the two trade-offs.

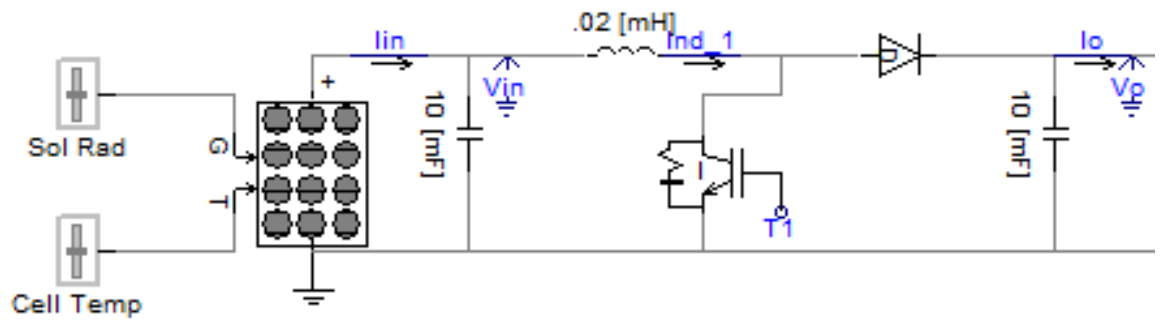

Figure 3-17: Boost Converter connected to the PV Array in PSCAD

The critical inductance that yields Continuous Conduction Mode is determined from the minimum value of inductor current $\mathrm{I}_{\mathrm{L}-\mathrm{min}}$ as:

$$
L_{C}=\frac{D(1-D)^{2} R}{2 f}
$$


In 3-21 "R" represents the load resistance. Minimum of five DC houses will be consuming $2.5 \mathrm{~kW}$ of power almost entirely. Load in terms of resistance for five houses is calculated to be:

$$
R=\frac{V^{2}}{P}=\frac{48^{2}}{2500}=.9216 \Omega
$$

And, for a 50\% duty cycle the Critical inductance is calculated to be:

$$
L_{C}=\frac{.5(1-.5)^{2} * .9218}{2 * 20 \times 10^{3}}=2.88 \mu H
$$

The duty cycle of the converter varies according to the weather and load conditions. Therefore, a higher value for the inductor is preferred to ensure that the converter is working in CCM mode at all time. The inductor of $20 \mu \mathrm{H}$ was tested and chosen to keep the converter in CCM mode under varying weather and load conditions.

The output capacitor value is determined by:

$$
C=\frac{D}{R f} \times \frac{V_{O}}{\Delta V_{O}}
$$

A $50 \%$ duty cycle at $25 \mathrm{~V}$ input voltage will boost the output voltage to $50 \mathrm{~V}$, and the output capacitor required in this case would be:

$$
C=\frac{.5}{.1884 * 20 \times 10^{3}} \times \frac{50}{1}=6.7 \mathrm{mF}
$$

The output voltage ripple has an inverse relationship with the output capacitor value, so a lower output ripple will require a bigger capacitor. As mentioned, this 
converter will have varying duty cycle according to the different weather and load conditions. A $10 \mathrm{mf}$ capacitor was chosen for different operating conditions.

\section{6: $\quad$ Buck Converter Operation}

As mentioned earlier, the second DC-DC converter in the system needs to convert the varying output voltage of the Boost Converter to a stable 48V DC bus distribution voltage. Additionally this converter must have low output current ripple, so smooth power is delivered to the DC bus. The Buck Converter topology fulfills both of these requirements. It has low output current ripple due to the inductor's location in the circuit, as illustrated in Figure 3-18 [32]. The cascading of Boost and Buck converter provides good input and output current characteristics. As mentioned in the previous section, the desired mode of operation for these converters is the Continuous Conduction Mode. Therefore, all the following equations are derived in the Continuous Conduction Mode.

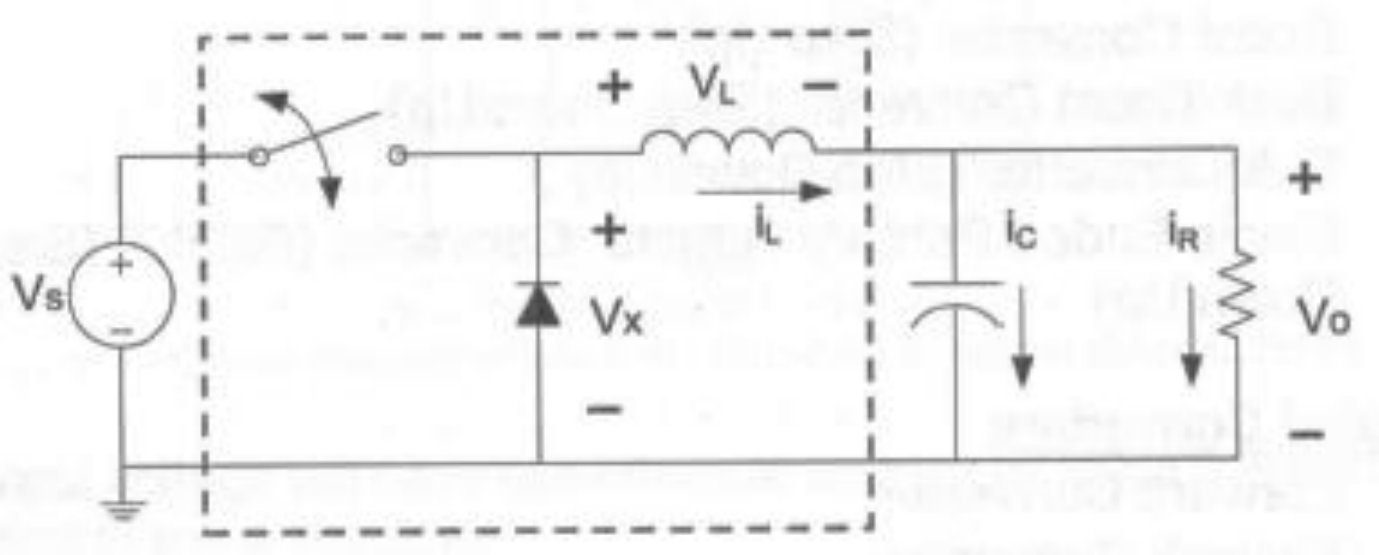

Figure 3-18: Buck Converter Block Diagram [32] 
Similar to Boost, Buck converter also has two states in the Continuous

Conduction Mode: Switch ON and Switch OFF. In the switch ON state, the diode is reverse biased (Figure 3-19), and the voltage across the inductor is:

$$
V_{L}=V_{S}-V_{O}
$$

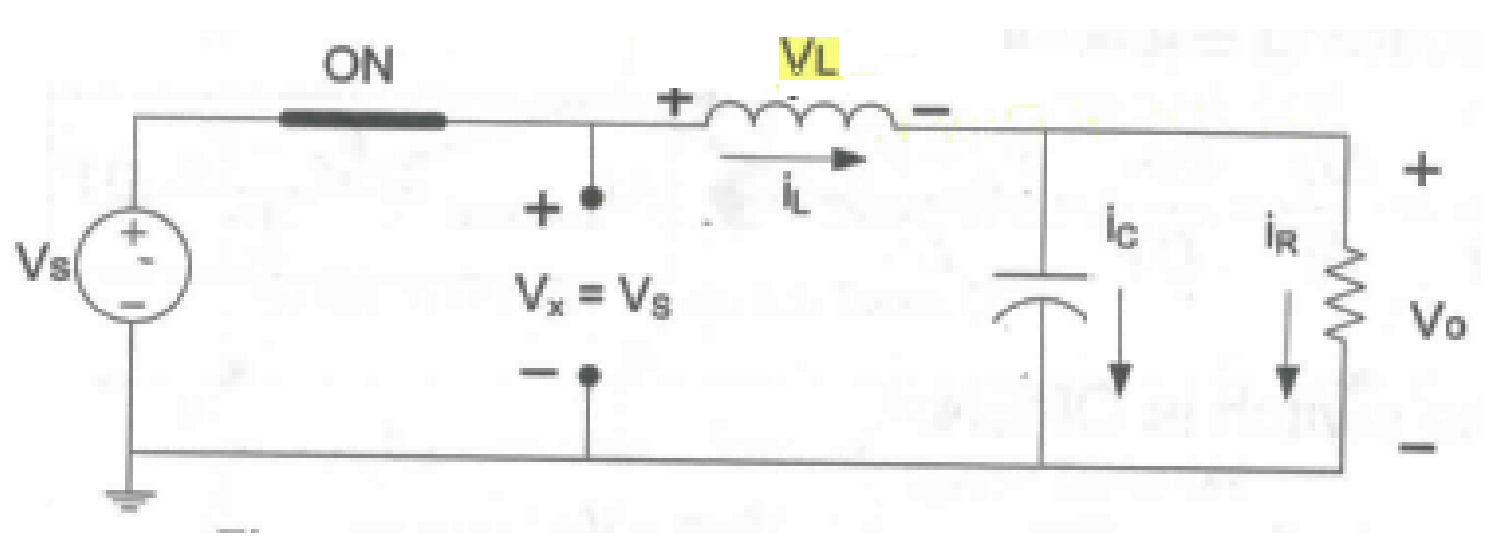

Figure 3-19: Buck Converter CCM Switch ON State [32]

The change in the inductor current is calculated as:

$$
\begin{gathered}
\frac{d i_{L t}}{d t}=\frac{\Delta i_{L}}{\Delta t}=\frac{\Delta i_{L}}{D T}=\frac{V_{S}-V_{O}}{L} \\
\Delta i_{L-\text { closed }}=\frac{\left(V_{S}-V_{O}\right)}{L} D T
\end{gathered}
$$

The second state of the Buck converter is illustrated in Figure 3-20. In this state switch is turned off and the voltage across inductor is:

$$
V_{L}=-V_{0}=L \frac{d i_{L}}{d t}
$$




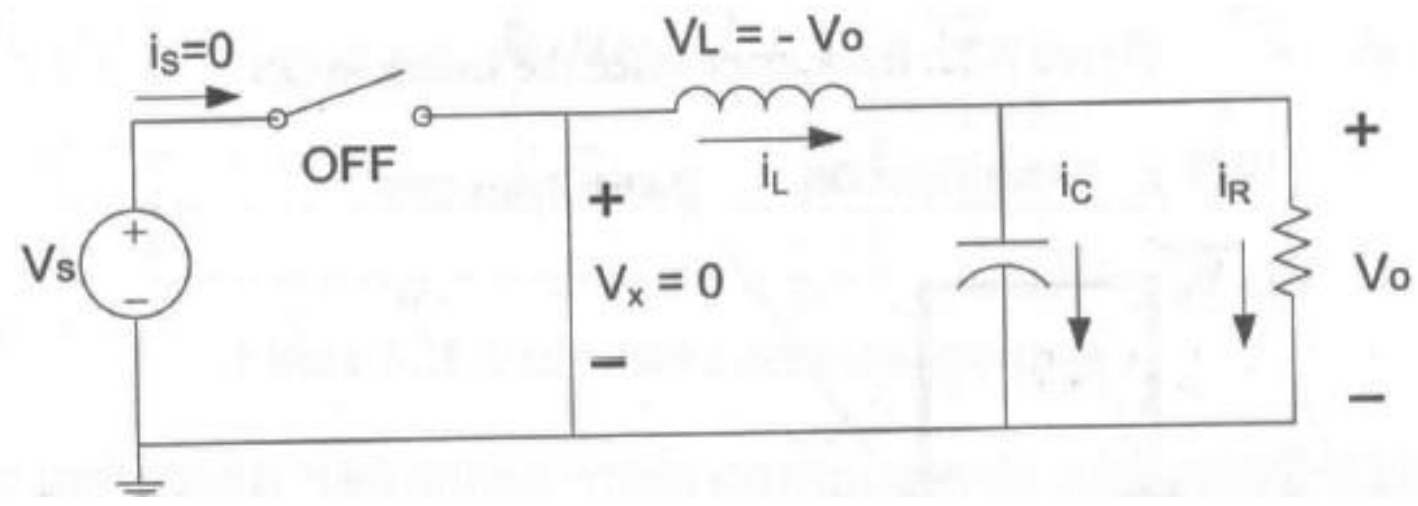

Figure 3-20: Buck Converter CCM Switch OFF State [32]

The change in the inductor current is computed as:

$$
\begin{gathered}
\frac{\Delta i_{L}}{t_{\text {off }}}=\frac{\Delta i_{L}}{T-D T}=\frac{\Delta i_{L}}{(1-D) T}=-\frac{V_{O}}{L} \\
\Delta i_{L-\text { open }}=-\frac{V_{O}}{L}(1-D) T
\end{gathered}
$$

In steady state operation the net change in the inductor current is zero. Therefore the output voltage of the Buck Converter is:

$$
\begin{gathered}
\Delta i_{L-1 \text { period }}=\Delta i_{L-\text { closed }}+\Delta i_{L-\text { open }}=0 \\
0=\frac{V_{S}-V_{O}}{L} D T-\frac{V_{O}}{L}(1-D) T \\
0=\frac{V_{S}}{L} D T-\frac{V_{O}}{L} D T-\frac{V_{O}}{L} T+\frac{V_{o}}{L} D T \\
V_{o}=D V_{S}
\end{gathered}
$$




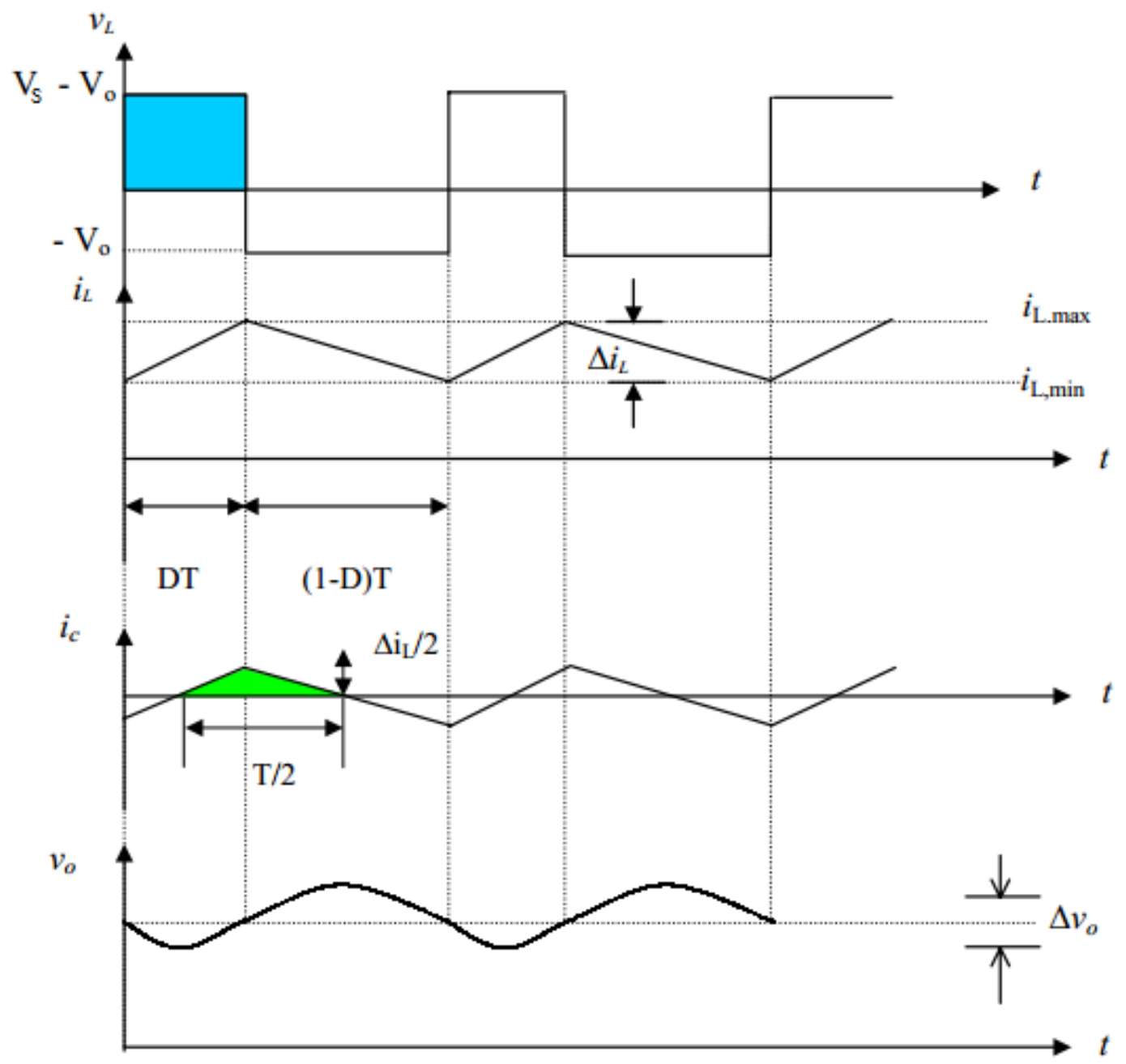

Figure 3-21: Buck Converter CCM Waveforms [34]

The Buck Converter waveforms are shows in Figure 3-21. As mentioned earlier, when the switch is ON, the inductor current increases linearly and capacitor is charged. And, when the switch is OFF, the inductor current decrease linearly and capacitor discharges to supply the load. The net change in the inductor current in the steady state is zero. The output voltage ripple is a function of the output capacitor. A bigger capacitor at the output will result in low ripple in the output voltage ripple [32]. 


\subsection{1: Buck Converter PSCAD implementation}

In PSCAD the Buck Converter is cascaded with the Boost Converter as shown in Figure 3-22. The output voltage of the Buck Converter is regulated at $48 \mathrm{~V}$ while the input voltage varies depending on the solar irradiance, temperature and load. Figure 3-23 illustrates the PI controller used for the output voltage regulation. In order to get a regulated $48 \mathrm{~V}$ at the $\mathrm{DC}$ bus, the controller compares the output voltage of the Buck Converter (DC bus voltage) to the reference $48 \mathrm{~V}$. If the output voltage is lower than $48 \mathrm{~V}$, the switch turns on to charge the output capacitor; if the output voltage is higher than $48 \mathrm{~V}$, the switch turns off to discharge the output capacitor. The switching frequency of the converter is $20 \mathrm{kHz}$.

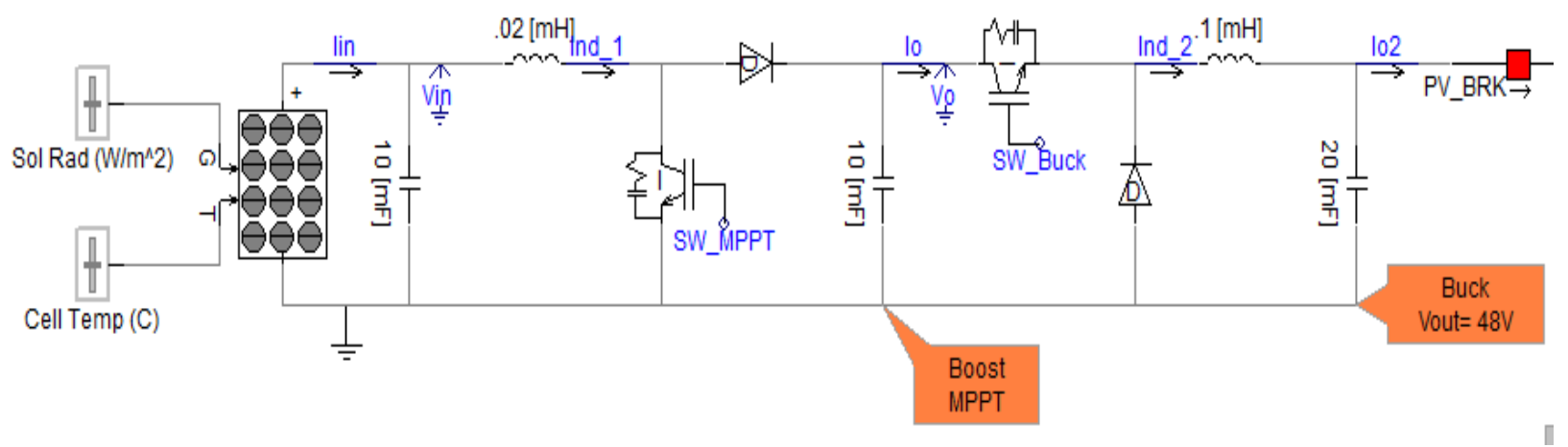

Figure 3-22: Buck Converter Cascaded with Boost Converter in PSCAD 


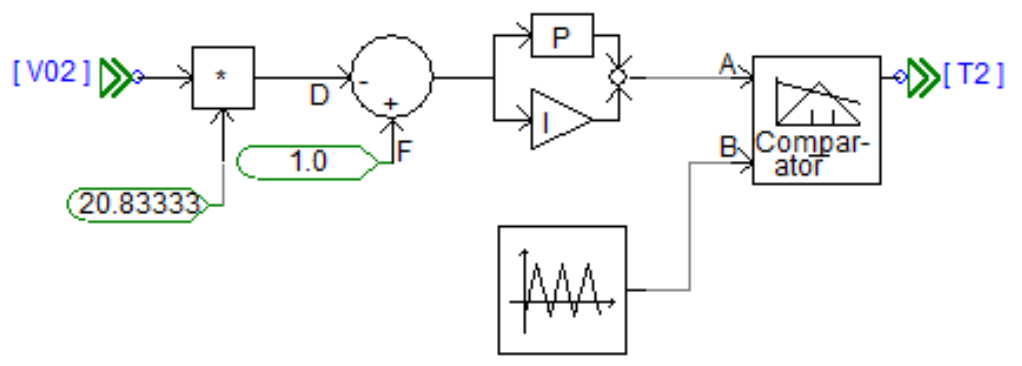

Figure 3-23: Buck Converter Switch Controller for Regulating Output Voltage at 48V

The critical inductance of the converter is computed as:

$$
\begin{gathered}
L_{C}=\frac{(1-D) R_{\max }}{2 f} \\
L_{C}=\frac{(1-.5) * .9218}{2 * 20000}=.011 \mathrm{mH}
\end{gathered}
$$

But a $.1 \mathrm{mH}$ was selected because the load resistance can go higher and duty cycle can go lower under different test conditions.

The minimum capacitor required at the output is computed as:

$$
\begin{gathered}
C_{O}=\frac{1-D}{\frac{\Delta V}{V_{o}} 8 L f^{2}} \\
C_{o}=\frac{1-.2}{\frac{1}{48} 8(.0001)(20000)^{2}}=.12 m f
\end{gathered}
$$




\section{7: Battery Bank}

PV power generation varies with the amount of sunlight shining on the panels at an instance, which results in lack of power generation during night time and cloudy weather. At such times, a battery bank is needed in order to provide smooth power to the load continuously. There are four major types of rechargeable batteries used as energy storing devices: Lead Acid, Nickel-51Cadmium (NiCD), Nickel-metal-hydride (NiMH), Lithium-ion (Li-ion). Figure 3-25 shows the discharge characteristics of an individual cell for the batteries.

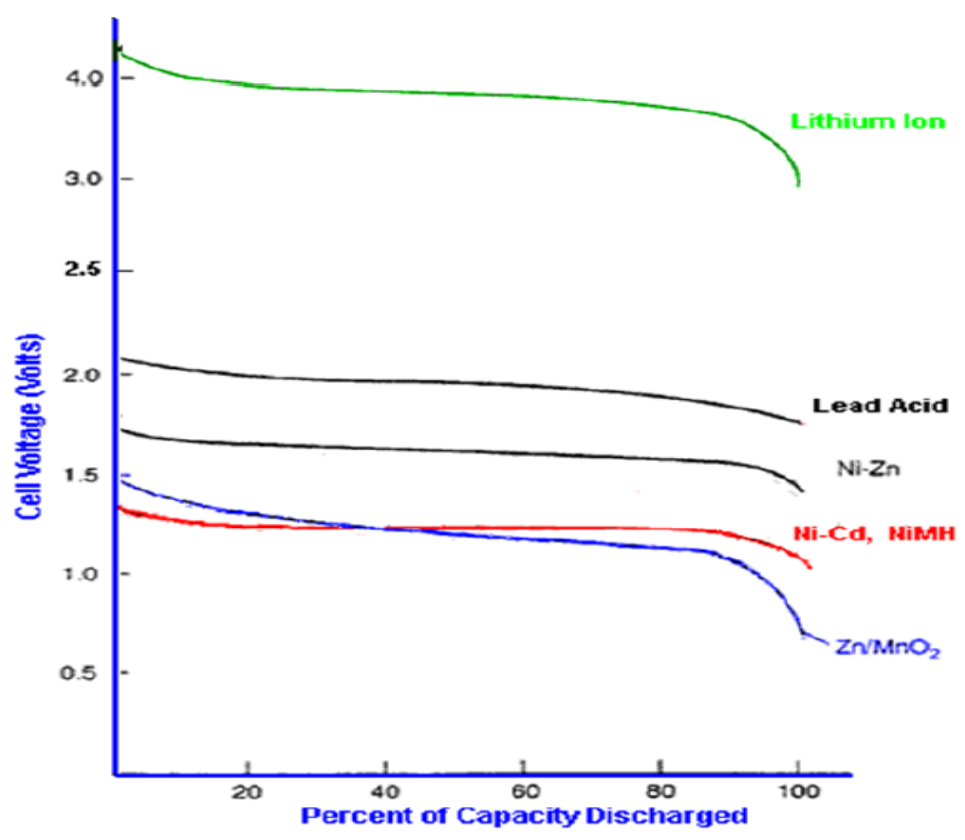

Figure 3-25: Cell Discharge Characteristics of Four Battery Types

In order to determine the optimal battery type, the major attributes to focus on are the specific energy, years of service life, load characteristics, price, safety, self-discharge, environmental issues, and disposal. $\mathrm{NiCD}, \mathrm{NiMH}$, and Li-ion batteries are usually used in 
critical and extreme temperature applications [23]. However the reason they are not likely candidates for use in PV systems is because their high initial costs and unavailability offset their advantageous characteristics.

Lead Acid batteries are one of the oldest rechargeable battery systems created by French Physicist Gaston Plante in 1859 [24]. Their low cost, high tolerance to overcharge and over-discharge characteristics make them ideal for isolated PV systems. There are three different types of lead acid batteries available in the market today: flooded leadacid, gelled electrolyte, and absorbed glass mat (AGM). Gelled electrolyte and AGM are also commonly referred to as sealed or valve-regulated lead acid batteries (VRLA). The advantages and disadvantages of these two different battery types are compared in Table 3-2.

Table 3-2: Comparison of Flooded Lead-Acid and VRLA Battery Types [23]

\begin{tabular}{|c|c|c|}
\hline Battery Type & Advantages & Disadvantages \\
\hline \multicolumn{3}{|l|}{ Flooded Lead-Acid } \\
\hline Lead-Antimony & $\begin{array}{l}\text { low cost, wide availability, good } \\
\text { deep cycle and high temperature } \\
\text { performance, can replenish } \\
\text { electrolyte }\end{array}$ & high water loss and maintenance \\
\hline Lead-Calcium Open Vent & $\begin{array}{l}\text { low cost, wide availability, low } \\
\text { water loss, can replenish } \\
\text { electrolyte }\end{array}$ & $\begin{array}{l}\text { poor deep cycle performance, } \\
\text { intolerant to high temperatures } \\
\text { and overcharge }\end{array}$ \\
\hline Lead-Calcium Sealed Vent & $\begin{array}{l}\text { low cost, wide availability, low } \\
\text { water loss }\end{array}$ & $\begin{array}{l}\text { poor deep cycle performance, } \\
\text { intolerant to high temperatures } \\
\text { and overcharge, can not replenish } \\
\text { electrolyte }\end{array}$ \\
\hline $\begin{array}{l}\text { Lead Antimony/Calcium } \\
\text { Hybrid }\end{array}$ & medium cost, low water loss & $\begin{array}{l}\text { limited availability, potential for } \\
\text { stratification }\end{array}$ \\
\hline \multicolumn{3}{|c|}{ Captive Electrolyte Lead-Acid } \\
\hline Gelled & $\begin{array}{l}\text { medium cost, little or no } \\
\text { maintenance, less susceptible to } \\
\text { freezing, install in any orientation }\end{array}$ & $\begin{array}{l}\text { fair deep cycle performance, } \\
\text { intolerant to overcharge and high } \\
\text { temperatures, limited availability }\end{array}$ \\
\hline Absorbed Glass Mat & $\begin{array}{l}\text { medium cost, little or no } \\
\text { maintenance, less susceptible to } \\
\text { freezing, install in any orientation }\end{array}$ & $\begin{array}{l}\text { fair deep cycle performance, } \\
\text { intolerant to overcharge and high } \\
\text { temperatures, limited availability }\end{array}$ \\
\hline
\end{tabular}


These Gelled and AGM (VRLA) batteries are designed to minimize the required maintenance over the life of the battery. In the small PV systems, VRLAs are the most popular because of their low maintenance requirements, even though their cost is higher than the Flooded Lead-Acid batteries. Other differentiating attributes include the impossibility of adding an electrolyte to the VRLA batteries due to their seal construction type. The sealed construction makes VRLA batteries extremely intolerant to overcharging and high temperatures [23]. Hence, the Flooded Lead-acid batteries are the most ideal battery type for the centralized DC House distribution system. In the next section, the implementation of Lead-acid battery model is discussed.

\subsection{1: Battery Bank PSCAD Implementation}

The battery is modeled by a controlled voltage source in series with a constant resistance, as shown in Figure 3-26.

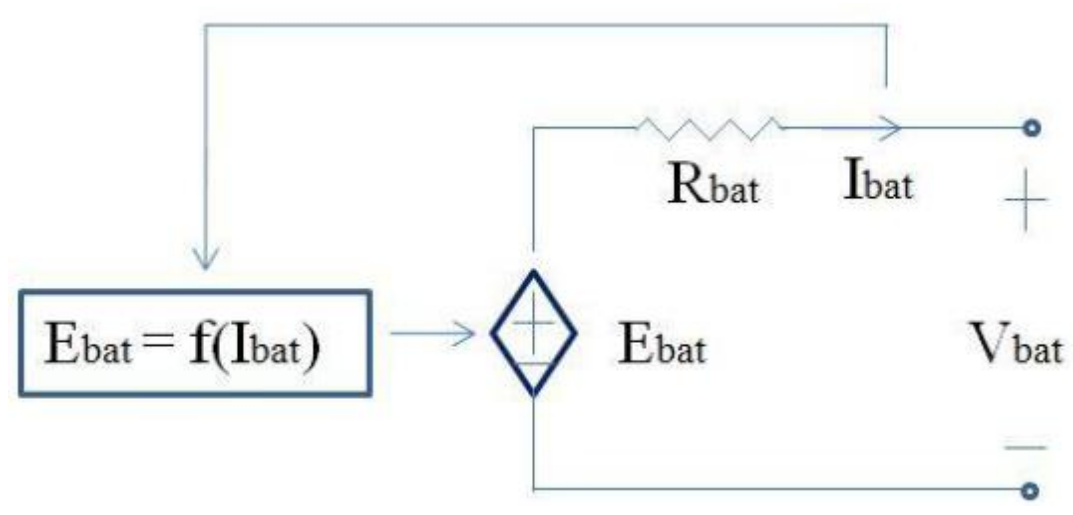

Figure 3-26: Battery Equivalent Circuit Diagram [18] 
This basic equivalent battery circuit is represented by shepherd's equation as:

$$
E_{b a t}=E_{O}-K * \frac{(1-S O C)}{S O C} * Q+A e^{-B(1-S O C) Q}
$$

The voltage at the battery terminal is calculated as:

$$
V_{b a t}=E_{b a t}-R_{b a t} * I_{b a t}
$$

where:

$$
\begin{aligned}
& E_{b a t} \text { : internal voltage }(V) \\
& E_{0} \text { : battery voltage constant }(V) \\
& \text { K: polarization constant }(\mathrm{V} / \mathrm{Ah}) \text { or polarization resistance }(\Omega) \\
& \text { SOC : State of charge }(\%) \\
& \text { Q: battery capacity }(\mathrm{Ah})
\end{aligned}
$$
A: exponential Zone amplitude (V)
B: exponential zone time constant inverse (1/Ah)
$\mathrm{V}_{\text {bat: }}$ terminal voltage $(\mathrm{V})$
$\mathrm{I}_{\text {bat: battery current }(\mathrm{A})}$

Figure 3-27 illustrate the custom battery component available in PSCAD, which implements equation 3-46.

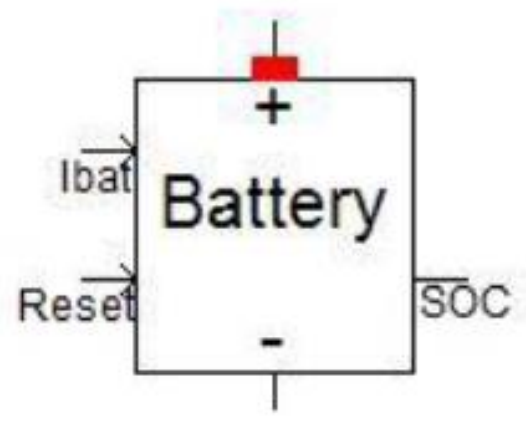

Figure 3-27: Battery Custom Component in available in PSCAD 
where:

- Ibat: The current of the battery, input signal.

- Reset: The control signal used to control charge or discharge of the battery, input signal.

- SOC: State of charger, output signal

The five battery type options available in PSCAD model are: Li-ion, Lead acid, $\mathrm{Ni}-\mathrm{Cd}, \mathrm{Ni}-\mathrm{MH}$ and User defined. As discussed in the previous section, Lead-acid battery type is the optimum choice for the isolated PV backup system. The parameters of the Lead-acid model are illustrated in Figure 3-28.

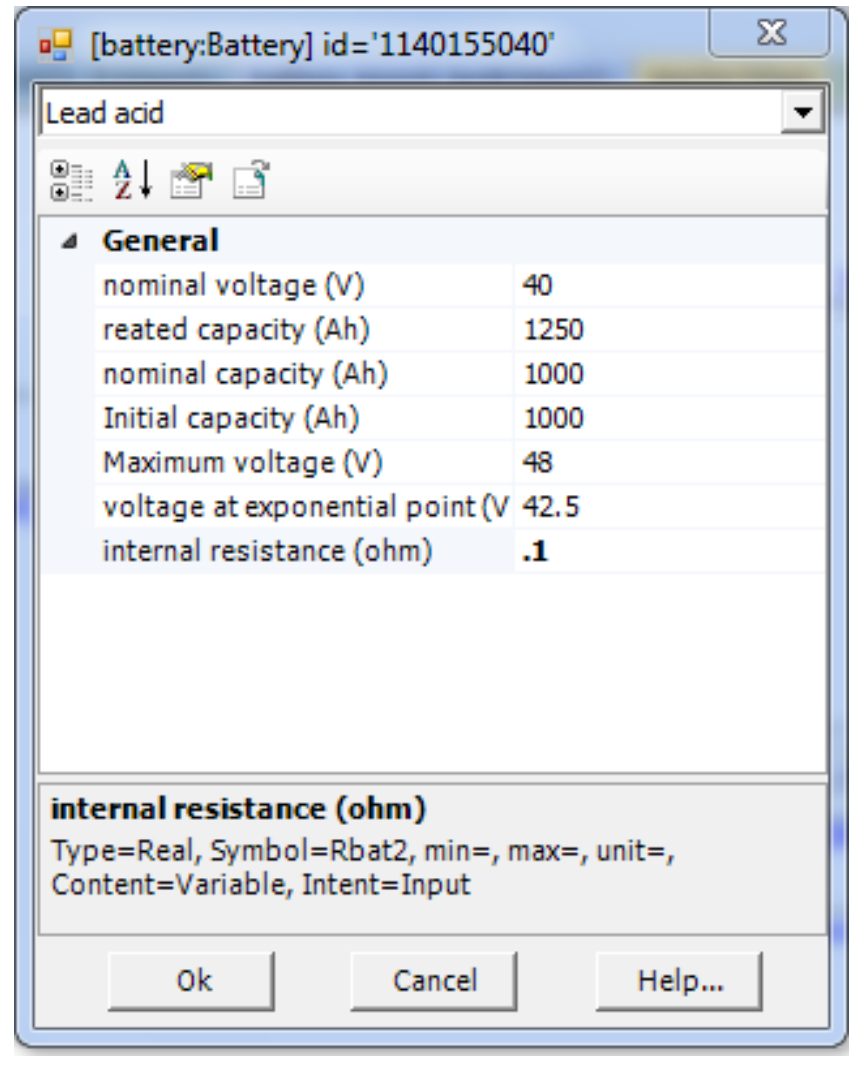

Figure 3-28: Lead-Acid Battery Parameters 
- Nominal Voltage (V): End of the linear zone of the discharge characteristics

- Rated Capacity (Ah): Rated capacity of the battery

- Initial Capacity (Ah): Initial condition for the simulation and does not affect the discharge curve

- Nominal capacity (Ah): The amount of current that can be extracted from the battery before it needs to recharge

- Voltage at exponential point (V): The exponential point corresponds to the end of the exponential zone

- Maximum Voltage (V): Battery voltage when its fully charged

- Internal Resistance $(\Omega)$ : Internal resistance of the battery

The voltage of battery cell varies in accordance with its charge state (Figure 325). Similarly, the terminal voltage of the battery bank will decrease as its SOC (state of charge) goes down. But the battery bank needs supply power to the load consistently at $48 \mathrm{~V}$ during the non-generation periods. A DC-DC converter with regulated output helps to meet this design requirement. Figure 3-29 illustrates the battery bank design implemented in PSCAD. The top path is used for charging the battery and it is discharged through the bottom path. Boost Converter (sub-module "Boost-Bat1") stepsup the battery terminal voltage to $48 \mathrm{~V}$ DC Bus voltage when the load is supplied from the battery. Figure3-30 illustrates the Boost Converter and controller with-in the submodule. 


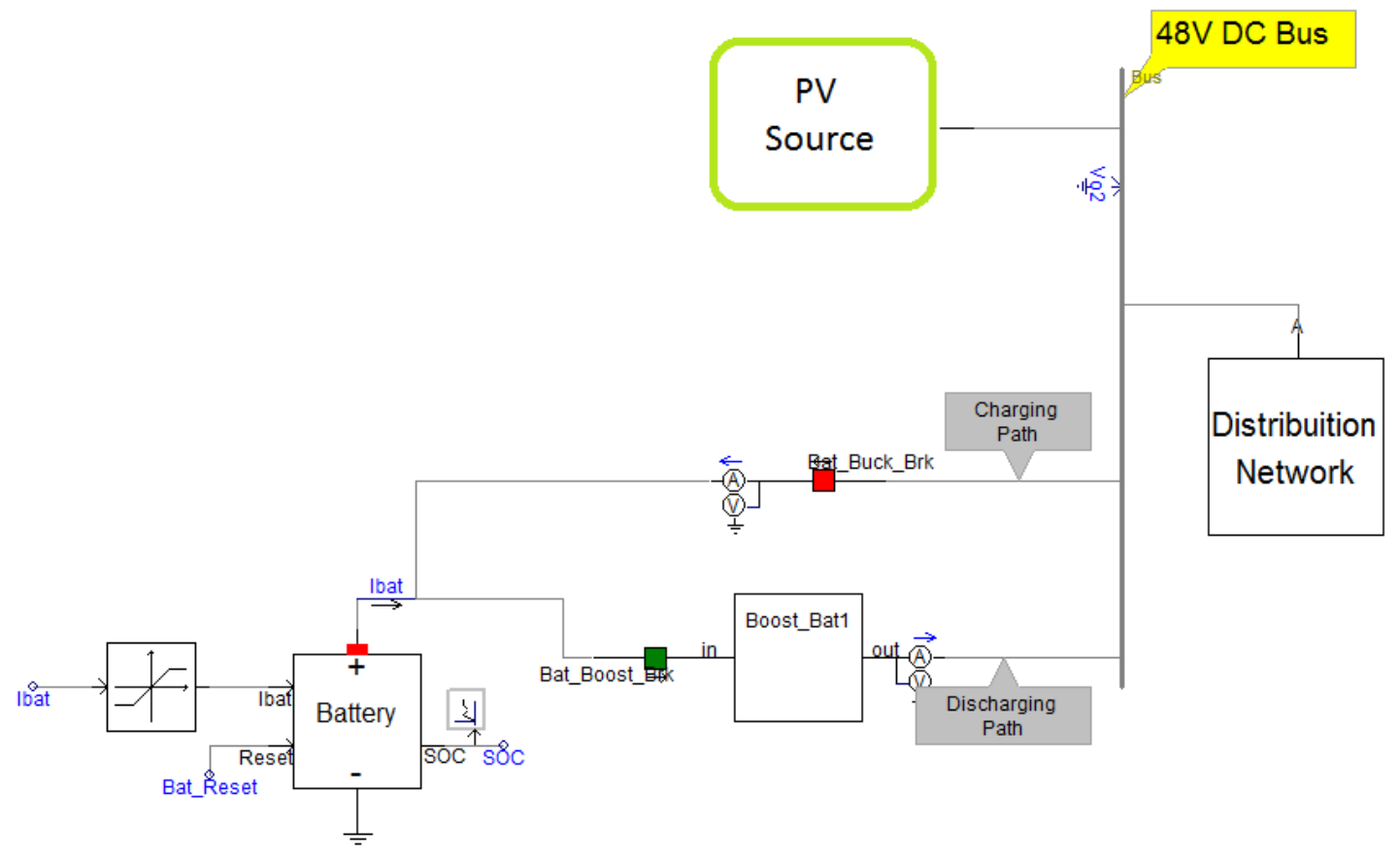

Figure 3-29: Complete Battery Bank Design
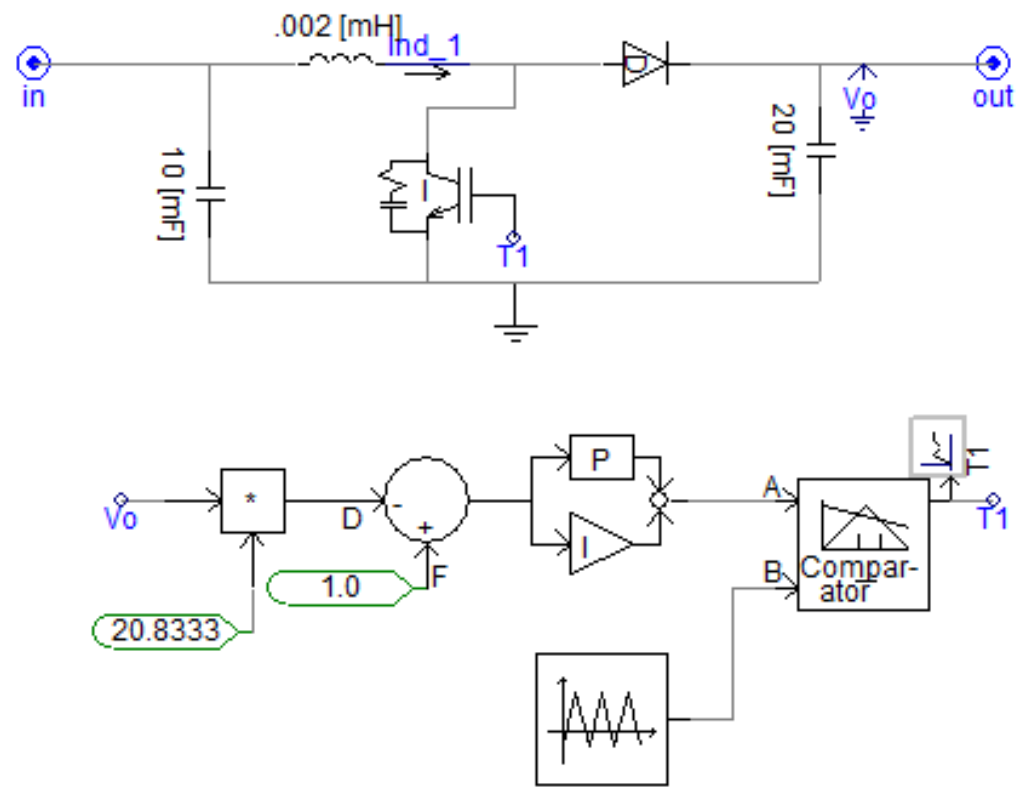

Figure 3-30: Boost Converter (top) and Controller (bottom) within the Sub-Module Battery Cascaded 


\section{8: Distribution Network}

The centralized distribution network for the DC houses is illustrated in Figure 331. This network consists of overhead distribution cables, five feeders and a total of 25 DC houses. The layout is modeled in PSCAD using common feeder characteristics that system planners use in suburban residential regions [15]. Figure 32 illustrates a magnified view of individual feeder with five houses. A single DC House load can be varied from 100-500W.

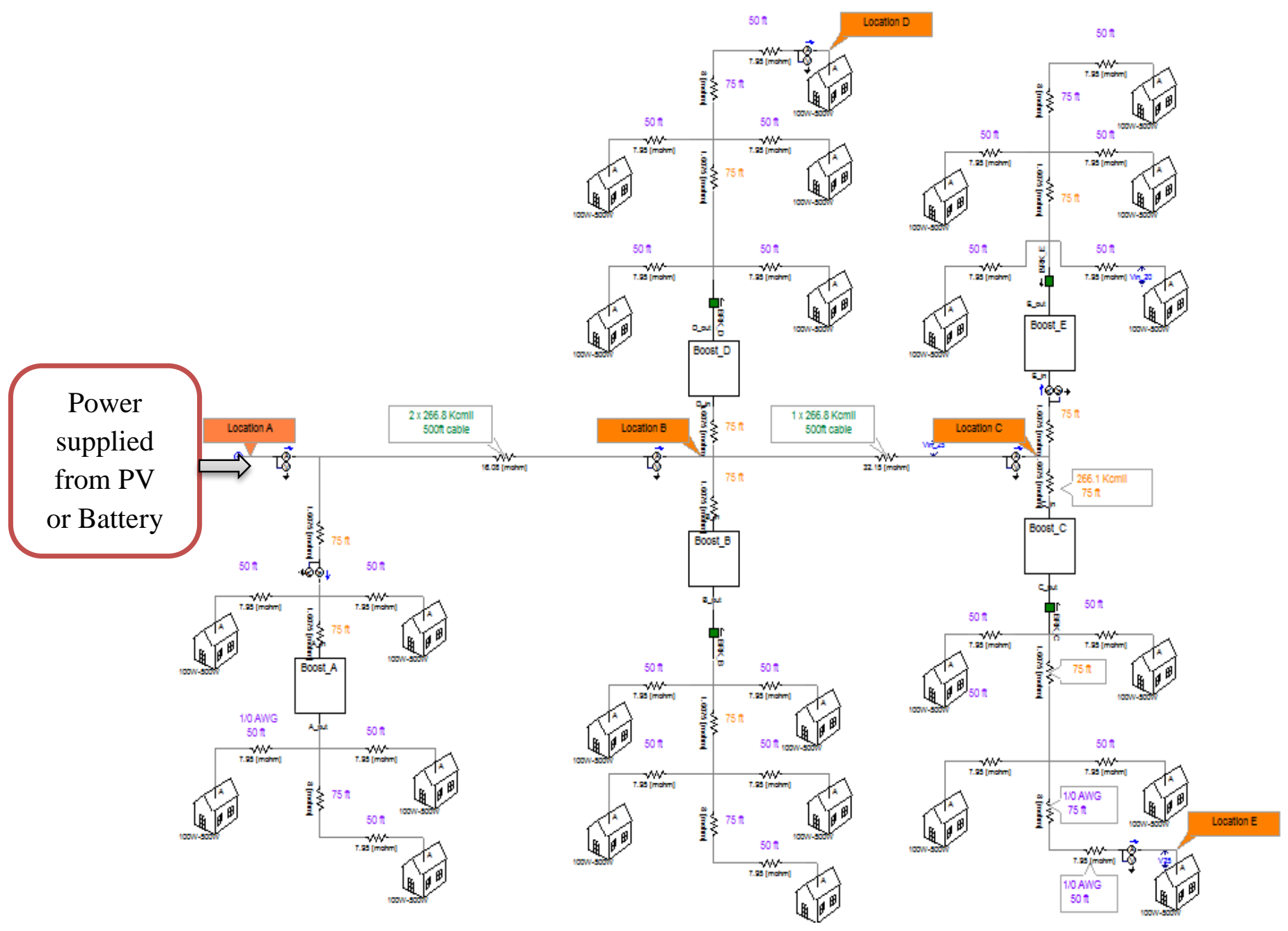

Figure 3-31: Distribution Network Design for 25 DC Houses 


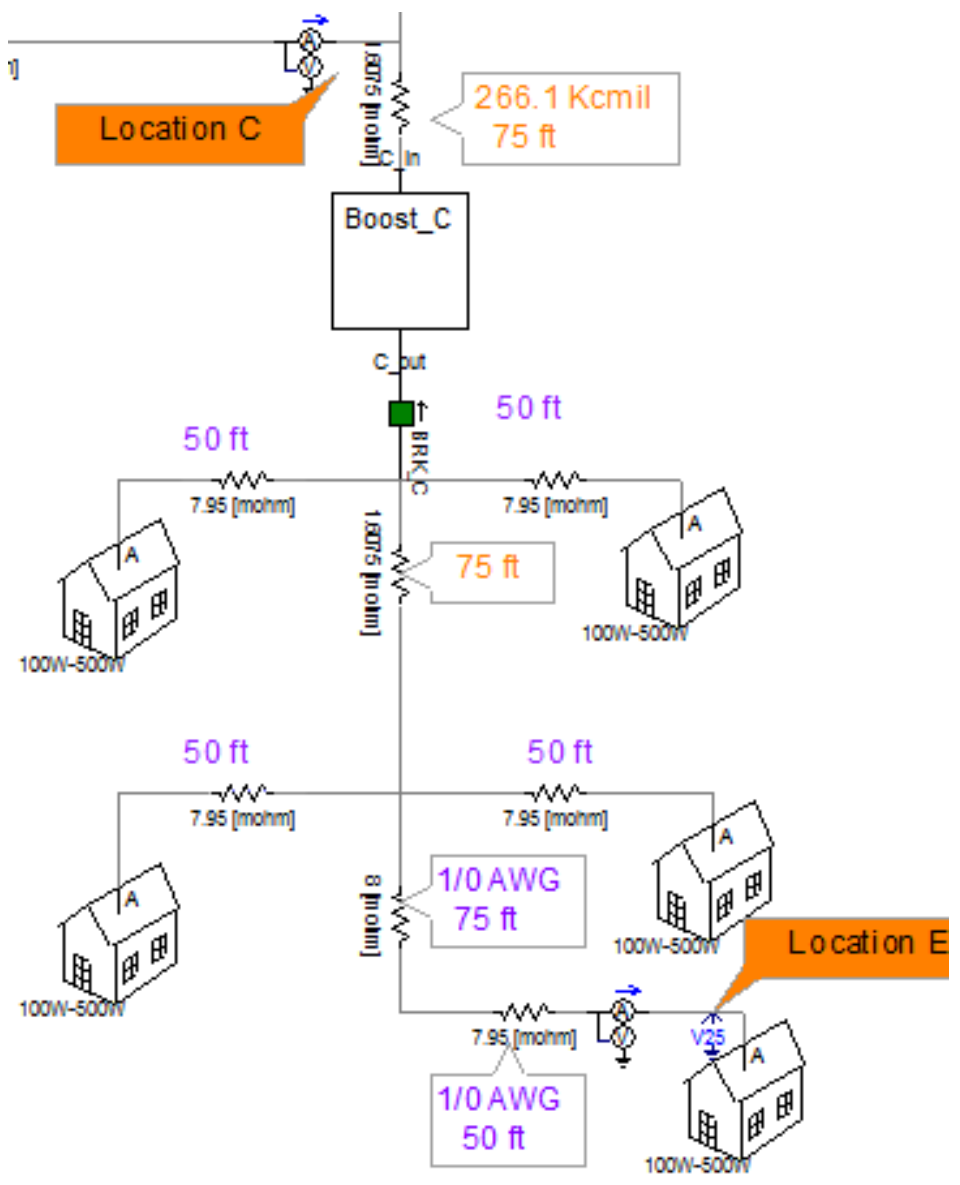

Figure 3-32: Magnified view of Feeder C Supplying Power to 5 DC Houses

Figure 3-33 shows the power flow in a basic DC circuit. The power loss in a DC circuit is directly proportional to the conductor resistance and the amount of current flowing through the conductor as shown by following equation:

$$
P_{\text {Loss }}=P_{\text {source }}-P_{\text {Load }}=V_{D C} * I-V_{2} * I=I^{2} * R
$$




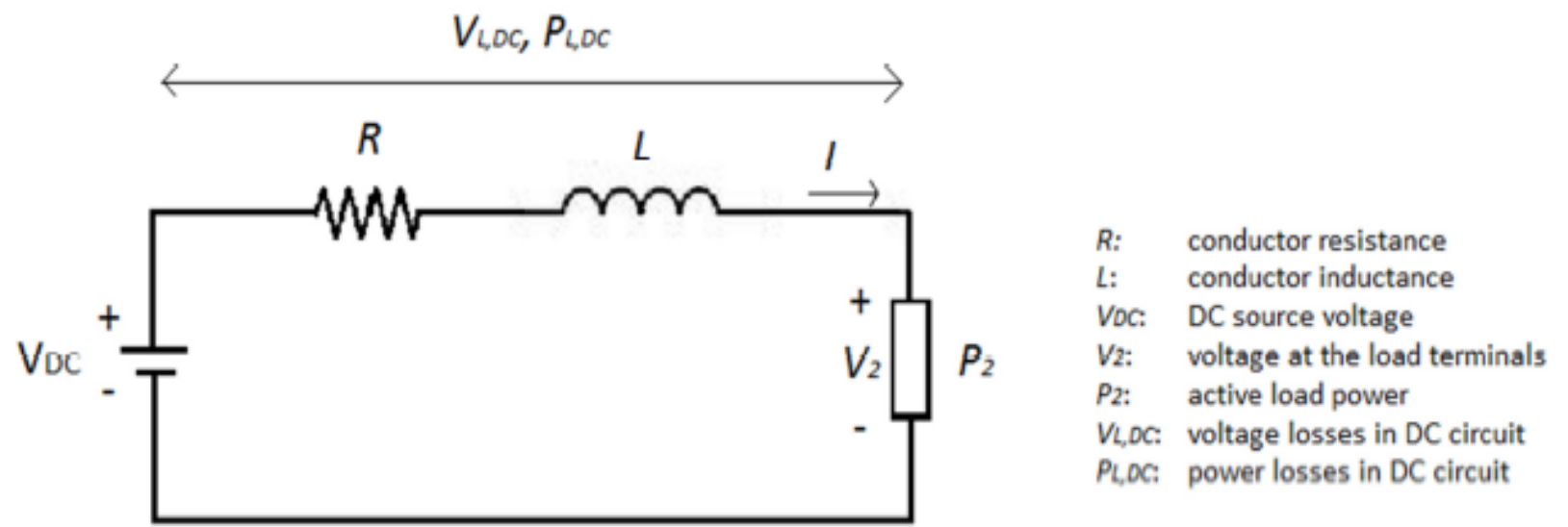

Figure 3-33: DC Equivalent Circuit Diagram [8]

At full load, the minimum current will be:

$$
I_{\text {full-load }}=\frac{P}{V_{D C-B u s}}=\frac{25 * 500}{48}=260.42 \mathrm{~A}
$$

Equation 3-49 shows distribution network will have high currents due to the low distribution voltage, therefore minimum resistance is desired in the distribution conductors in order to minimize distribution loses. Aluminum Conductor Steel Reinforced (ACSR) cables are frequently used for overhead power distribution. Their performance is highly reliable for many years even under adverse weather conditions. Table 3-3 shows the characteristics of the different ACSR cables. Waxing conductor at $266.9 \mathrm{kcmill}$ is selected based on the ampacity rating, DC resistance, and cost. The cable distances labeled in orange (Figure 3-31) corresponds to Waxwing conductor type. The 
cable distance labeled in purple corresponds to Raven $1 / 0 \mathrm{AWG}$ which is selected to connect a single DC House to the distribution network.

Table 3-3: ASCR Conductor Specifications Chart

\begin{tabular}{|c|c|c|c|c|c|c|c|c|c|c|c|c|c|c|c|}
\hline \multicolumn{16}{|c|}{ ACSR \& All Aluminum Cable Specification Chart } \\
\hline \multirow{3}{*}{ Code Word } & \multirow{3}{*}{$\begin{array}{c}\text { Size } \\
\text { (AWG } \\
\text { or } \\
\text { kcmil) }\end{array}$} & \multirow{3}{*}{$\begin{array}{l}\text { Strand- } \\
\text { ing } \\
\text { (Al/Stl) }\end{array}$} & \multicolumn{4}{|c|}{ Diameter (ins.) } & \multirow{2}{*}{\multicolumn{3}{|c|}{$\begin{array}{l}\text { Weight Per } 1000 \mathrm{ft} . \\
\text { (lbs.) }\end{array}$}} & \multirow{2}{*}{\multicolumn{2}{|c|}{ Content (\%) }} & \multirow{3}{*}{$\begin{array}{l}\text { Rated } \\
\text { Strength } \\
\text { (lbs.) }\end{array}$} & \multicolumn{2}{|c|}{$\begin{array}{l}\text { Resistance } \\
\text { OHMS/1000 ft. }\end{array}$} & \multirow{3}{*}{$\begin{array}{c}\text { Allowable } \\
\text { Ampacity+ } \\
\text { (Amps) }\end{array}$} \\
\hline & & & \multicolumn{2}{|c|}{ Individual Wires } & \multirow{2}{*}{$\begin{array}{l}\text { Steel } \\
\text { Core }\end{array}$} & \multirow{2}{*}{$\begin{array}{c}\text { Complete } \\
\text { Cable }\end{array}$} & & & & & & & DC@ & AC@ & \\
\hline & & & $\mathrm{Al}$ & Stl & & & $\mathrm{Al}$ & Stl & Total & $\mathrm{Al}$ & Stl & & $20^{\circ} \mathrm{C}$ & $75^{\circ} \mathrm{C}$ & \\
\hline $\begin{array}{c}\text { Turkey } \\
\text { Swan } \\
\text { Swanate } \\
\text { Sparrow } \\
\text { Sparate }\end{array}$ & $\begin{array}{l}6 \\
4 \\
4 \\
2 \\
2 \\
\end{array}$ & $\begin{array}{l}6 / 1 \\
6 / 1 \\
7 / 1 \\
6 / 1 \\
7 / 1 \\
\end{array}$ & $\begin{array}{l}.0661 \\
.0834 \\
.0772 \\
.1052 \\
.0974 \\
\end{array}$ & $\begin{array}{c}.0661 \\
.0834 \\
.103 \\
.1052 \\
.1298 \\
\end{array}$ & $\begin{array}{l}.0661 \\
.0834 \\
.103 \\
.1052 \\
.1298 \\
\end{array}$ & $\begin{array}{l}.198 \\
.25 \\
.257 \\
.68 \\
.325 \\
\end{array}$ & $\begin{array}{l}24 \\
39 \\
39 \\
62 \\
62 \\
\end{array}$ & $\begin{array}{l}12 \\
18 \\
28 \\
29 \\
45 \\
\end{array}$ & $\begin{array}{c}36 \\
57 \\
67 \\
91 \\
107 \\
\end{array}$ & $\begin{array}{c}67.88 \\
67.87 \\
58.1 \\
67.9 \\
58.12 \\
\end{array}$ & $\begin{array}{c}32.12 \\
32.12 \\
41.9 \\
32.1 \\
41.88 \\
\end{array}$ & $\begin{array}{l}1190 \\
1860 \\
2360 \\
2850 \\
3460 \\
\end{array}$ & $\begin{array}{l}.641 \\
.403 \\
.399 \\
.254 \\
.251 \\
\end{array}$ & $\begin{array}{l}.806 \\
.515 \\
.519 \\
.332 \\
.338 \\
\end{array}$ & $\begin{array}{l}105 \\
140 \\
140 \\
184 \\
184 \\
\end{array}$ \\
\hline $\begin{array}{c}\text { Robin } \\
\text { Raven } \\
\text { Quail } \\
\text { Pigeon } \\
\text { Penguin }\end{array}$ & $\begin{array}{c}1 \\
1 / 0 \\
2 / 0 \\
3 / 0 \\
4 / 0\end{array}$ & $\begin{array}{l}6 / 1 \\
6 / 1 \\
6 / 1 \\
6 / 1 \\
6 / 1 \\
\end{array}$ & $\begin{array}{l}.1181 \\
.1327 \\
.1489 \\
.1672 \\
.1878\end{array}$ & $\begin{array}{l}.1181 \\
.1327 \\
.1489 \\
.1672 \\
.1878\end{array}$ & $\begin{array}{l}.1181 \\
.1327 \\
.1489 \\
.1672 \\
.1878\end{array}$ & $\begin{array}{l}.354 \\
.398 \\
.447 \\
.502 \\
.563\end{array}$ & \begin{tabular}{|c|c|}
78 \\
99 \\
124 \\
156 \\
197
\end{tabular} & $\begin{array}{l}37 \\
47 \\
59 \\
74 \\
93\end{array}$ & $\begin{array}{l}115 \\
145 \\
183 \\
230 \\
291\end{array}$ & $\begin{array}{l}67.88 \\
67.89 \\
67.88 \\
67.87 \\
67.89\end{array}$ & $\begin{array}{l}32.12 \\
32.11 \\
32.12 \\
32.13 \\
32.12\end{array}$ & $\begin{array}{l}3550 \\
4380 \\
5310 \\
6620 \\
8350\end{array}$ & $\begin{array}{l}.201 \\
.159 \\
.126 \\
.100 \\
.0795\end{array}$ & $\begin{array}{l}.268 \\
.217 \\
.176 \\
.144 \\
.119\end{array}$ & $\begin{array}{l}212 \\
242 \\
276 \\
315 \\
357\end{array}$ \\
\hline $\begin{array}{c}\text { Waxwing } \\
\text { Partridge } \\
\text { Ostrich } \\
\text { Merlin } \\
\text { Linnet }\end{array}$ & $\begin{array}{c}266.8 \\
266.8 \\
300 \\
336.4 \\
336.4 \\
\end{array}$ & $\begin{array}{l}18 / 1 \\
26 / 7 \\
26 / 7 \\
18 / 1 \\
26 / 7 \\
\end{array}$ & $\begin{array}{l}.1217 \\
.1013 \\
.1074 \\
.1367 \\
.1137\end{array}$ & $\begin{array}{l}.1217 \\
.1013 \\
.1074 \\
.1367 \\
.1137\end{array}$ & $\begin{array}{l}.1217 \\
.1013 \\
.1074 \\
.1367 \\
.1137\end{array}$ & $\begin{array}{l}.609 \\
.642 \\
.68 \\
.684 \\
.72 \\
\end{array}$ & $\begin{array}{l}250 \\
251 \\
283 \\
315 \\
317\end{array}$ & $\begin{array}{c}39 \\
115 \\
130 \\
49 \\
146 \\
\end{array}$ & $\begin{array}{l}289 \\
367 \\
412 \\
365 \\
462 \\
\end{array}$ & $\begin{array}{c}86.43 \\
68.51 \\
68.51 \\
86.43 \\
68.5\end{array}$ & $\begin{array}{c}13.57 \\
31.49 \\
31.49 \\
13.57 \\
31.5\end{array}$ & $\begin{array}{c}6880 \\
11300 \\
12700 \\
8680 \\
14100 \\
\end{array}$ & $\begin{array}{l}.0643 \\
.0637 \\
.0567 \\
.0510 \\
.0505\end{array}$ & $\begin{array}{l}.0787 \\
.0779 \\
.0693 \\
.0625 \\
.0618\end{array}$ & $\begin{array}{l}449 \\
475 \\
492 \\
519 \\
529\end{array}$ \\
\hline $\begin{array}{c}\text { Oriole } \\
\text { Chickadee } \\
\text { Brant } \\
\text { Ibis } \\
\text { Lark }\end{array}$ & $\begin{array}{l}336.4 \\
397.5 \\
397.5 \\
397.5 \\
397.5\end{array}$ & $\begin{array}{l}30 / 7 \\
18 / 1 \\
24 / 7 \\
26 / 7 \\
30 / 7 \\
\end{array}$ & $\begin{array}{l}.1059 \\
.1486 \\
.1287 \\
.1236 \\
.1151\end{array}$ & $\begin{array}{l}.1059 \\
.1486 \\
.0858 \\
.0962 \\
.1151\end{array}$ & $\begin{array}{l}.3177 \\
.1486 \\
.2574 \\
.2885 \\
.3453\end{array}$ & $\begin{array}{l}.741 \\
.743 \\
.772 \\
.783 \\
.806 \\
\end{array}$ & $\begin{array}{l}318 \\
373 \\
374 \\
374 \\
375\end{array}$ & \begin{tabular}{c|}
209 \\
58 \\
137 \\
172 \\
247
\end{tabular} & $\begin{array}{l}526 \\
431 \\
511 \\
546 \\
622\end{array}$ & $\begin{array}{l}60.35 \\
86.43 \\
73.21 \\
68.51 \\
60.35\end{array}$ & $\begin{array}{l}39.65 \\
13.57 \\
26.79 \\
31.49 \\
39.65\end{array}$ & $\begin{array}{c}17300 \\
9940 \\
14600 \\
16300 \\
20300 \\
\end{array}$ & $\begin{array}{l}.0502 \\
.0432 \\
.0430 \\
.0428 \\
.0425\end{array}$ & $\begin{array}{l}.0613 \\
.0529 \\
.0526 \\
.0523 \\
.0519\end{array}$ & $\begin{array}{l}535 \\
576 \\
584 \\
587 \\
594\end{array}$ \\
\hline $\begin{array}{c}\text { Pelican } \\
\text { Flicker } \\
\text { Hawk } \\
\text { Hen } \\
\text { Osprey }\end{array}$ & $\begin{array}{c}477 \\
477 \\
477 \\
477 \\
556.5\end{array}$ & \begin{tabular}{l|}
$18 / 1$ \\
$24 / 7$ \\
$26 / 7$ \\
$30 / 7$ \\
$18 / 1$
\end{tabular} & $\begin{array}{l}.1628 \\
.141 \\
.1354 \\
.1261 \\
.1758\end{array}$ & $\begin{array}{l}.1628 \\
.094 \\
.1053 \\
.1261 \\
.1758\end{array}$ & $\begin{array}{l}.1628 \\
.2819 \\
.316 \\
.3783 \\
.1758\end{array}$ & $\begin{array}{l}.814 \\
.846 \\
.858 \\
.883 \\
.879\end{array}$ & $\begin{array}{l}447 \\
449 \\
449 \\
450 \\
522\end{array}$ & $\begin{array}{c}70 \\
164 \\
207 \\
296 \\
82\end{array}$ & $\begin{array}{l}517 \\
614 \\
656 \\
746 \\
603\end{array}$ & $\begin{array}{l}86.45 \\
73.21 \\
68.51 \\
60.35 \\
86.43\end{array}$ & $\begin{array}{l}13.56 \\
26.79 \\
31.49 \\
39.65 \\
13.57\end{array}$ & $\begin{array}{l}11800 \\
17200 \\
19500 \\
23800 \\
13700\end{array}$ & $\begin{array}{l}.0360 \\
.0358 \\
.0356 \\
.0354 \\
.0308\end{array}$ & $\begin{array}{l}.0442 \\
.0439 \\
.0436 \\
.0433 \\
.0379\end{array}$ & $\begin{array}{l}646 \\
655 \\
659 \\
666 \\
711\end{array}$ \\
\hline
\end{tabular}

The DC resistance of the conductors leads to voltage drop in the network that varies with the distance and the amount of current flowing in the cable $\left(V_{\text {drop }}=I \times R_{\text {cable }}\right)$. Therefore, DC-DC converters are required at strategic locations in the distribution network in order to boost the voltage back to $48 \mathrm{~V}$. Boost Converter typology is selected and its output voltage is regulated at $48 \mathrm{~V}$ with the PI controller as shown in Figure 3-34. The distribution network layout (Figure 3-31) shows the boost converter and controller sub-module placed at strategic locations. 

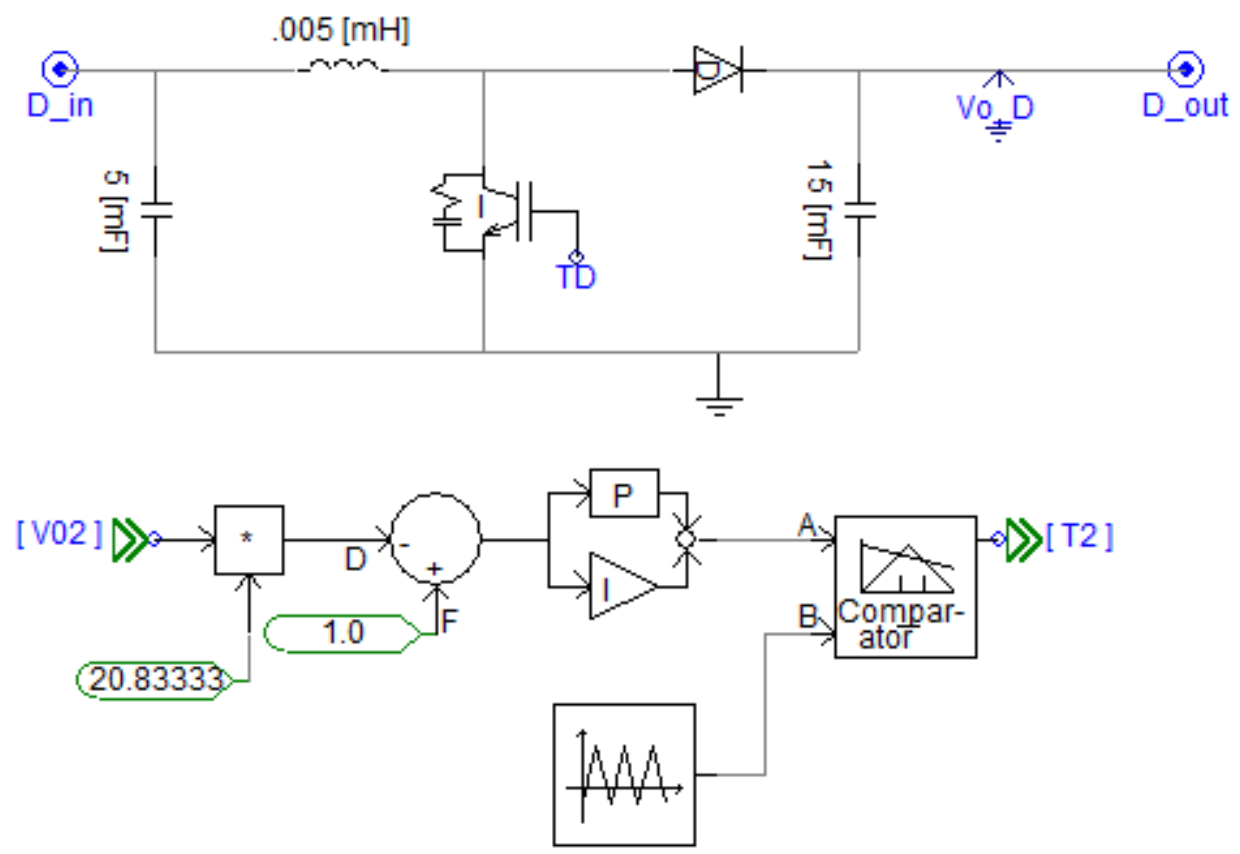

Figure 3-34: Boost Converter (top), and its Switch Controller (bottom) used in Distribution Network This completes the basic model for Centralized Distribution Network for DC House Project. Next chapter will focus on performance evaluation of the proposed design. 


\section{Chapter 4}

\section{System Validation}

In this chapter, the proposed design model for the centralized DC distribution network is validated. First, the operation of the Boost Converter and the MPPT controller is validated under varying solar radiation, temperature, and load. Then the operation of the Buck Converter is verified. The next steps involve the testing of the voltage stability of the network under different circumstances and the verification of battery charging with excessive PV power. Lastly, the PV source is turned off and battery bank is used to supply power to load to emulate night and cloudy conditions.

\section{1: MPPT and Boost Converter Validation}

The I-V (current versus voltage) characteristics of the PV module are nonlinear as shown in Figure 3-8. The operating voltage of the PV module determines the amount of power generated by the PV module. The maximum power is extracted from the PV when the module's operating voltage is around the knee of the I-V curve. For example, if the $\mathrm{PV}$ module is operating at $25 \mathrm{~V}$, then it generates close to $45 \mathrm{~W}$. Instead if the same PV module is operating at $5 \mathrm{~V}$, then it generates only $10 \mathrm{~W}$ (Figure $3-8$ ). Therefore, the desired operating voltage is around the knee of the module's I-V curve, where the maximum PV power is utilized. The maximum power extraction is achieved by dynamically alternating the duty cycle of the Boost Converter (Figure 4-1), which forces 
the PV array to operate around the knee of the I-V curve. Boost Converter's duty cycle is controlled by a maximum power point controller, which alternates the converter's duty cycle in accordance with three parameters: solar radiation, temperature and load. Next, three simulation test case results are presented. These depict the behavior of three different scenarios where $\mathrm{V}_{\mathrm{mpp}}$ of the array alters and MPPT controller's response to the variations is analyzed.

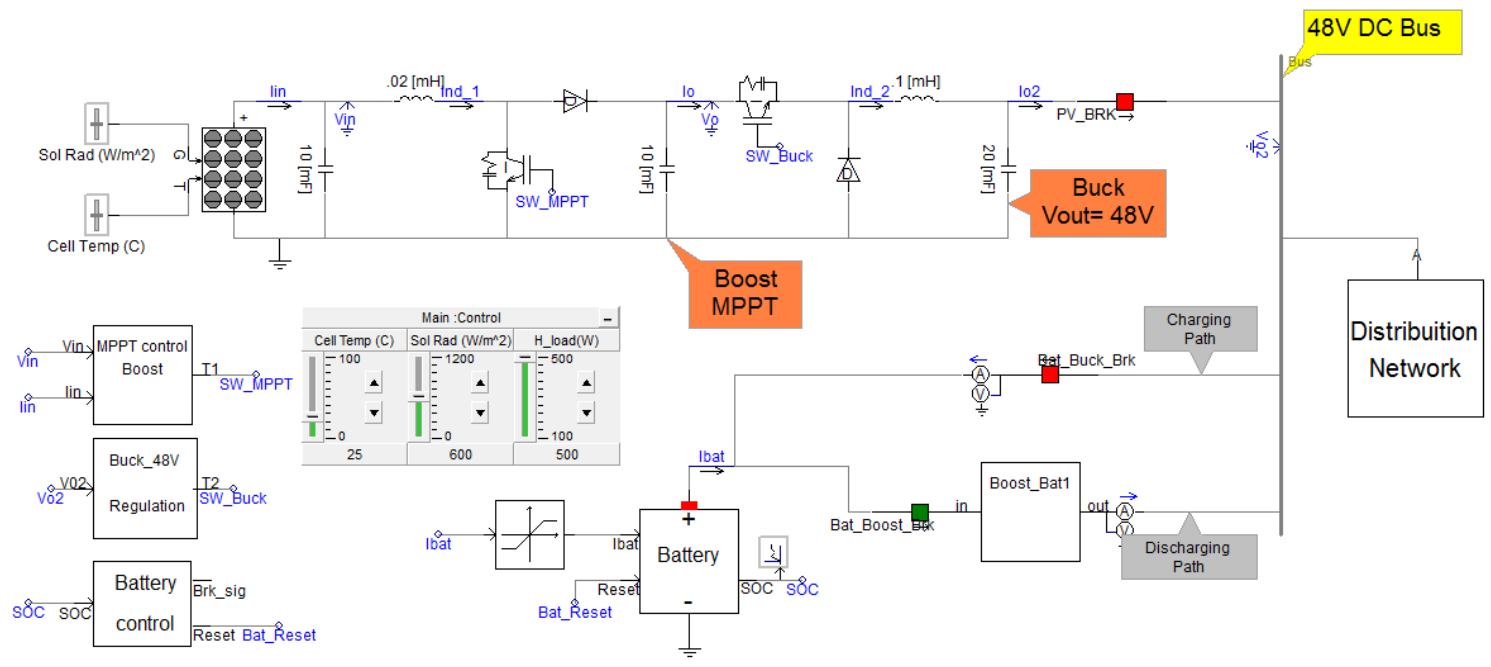

Figure 4-5: Complete System Design Implemented in PSCAD

Figure 4-2 shows the I-V characteristics of PV module with varying irradiance and temperature. Solar radiation primarily influences the output current of the PV module, while temperature mainly changes the output voltage of the PV module. These two parameters alternate the $\mathrm{V}_{\mathrm{mpp}}$ of the PV module dynamically. 


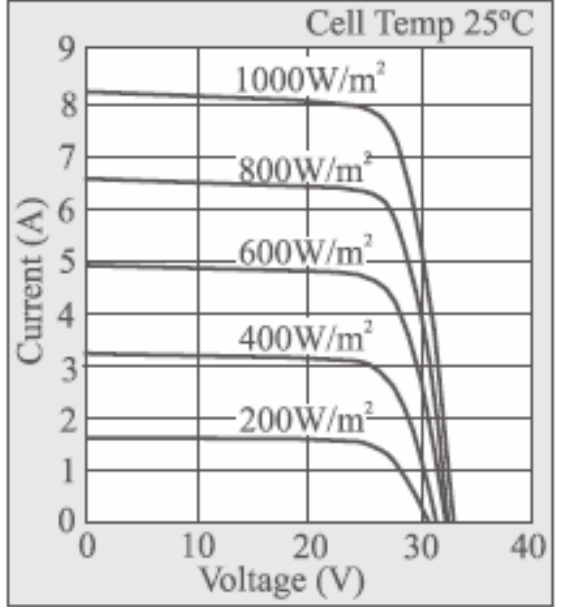

(a)

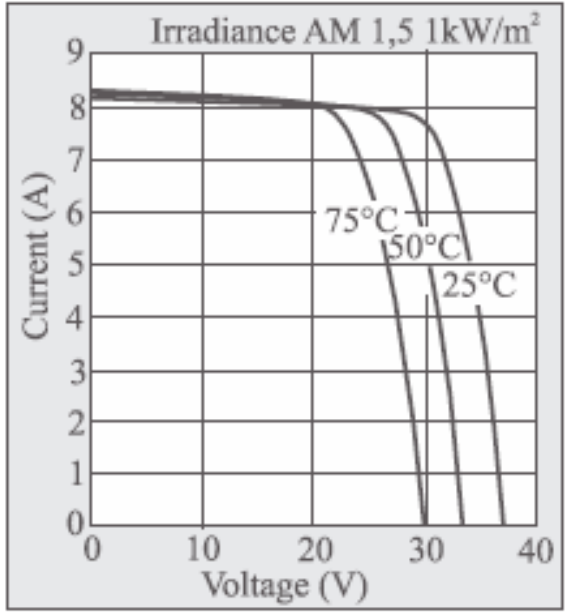

(b)

Figure 4-6: PV Module I-V Characteristic with Varying Solar Radiation (left) and Temperature (right) [35]

As the temperature increases, the $\mathrm{V}_{\text {mpp }}$ point of the PV module shifts to the left on the I-V curve (Figure 4-2) which needs to be tracked by the MPPT controller. In order to verify the response of the MPPT controller to temperature variations, the first test case is performed with the system operating at full load (25 DC houses consuming 500W each) while the temperature is varied from $5^{\circ} \mathrm{C}$ to $45^{\circ} \mathrm{C}$ in increments of $10^{\circ} \mathrm{C}$. The results of this simulation test case are shown in Figure 4-3. 


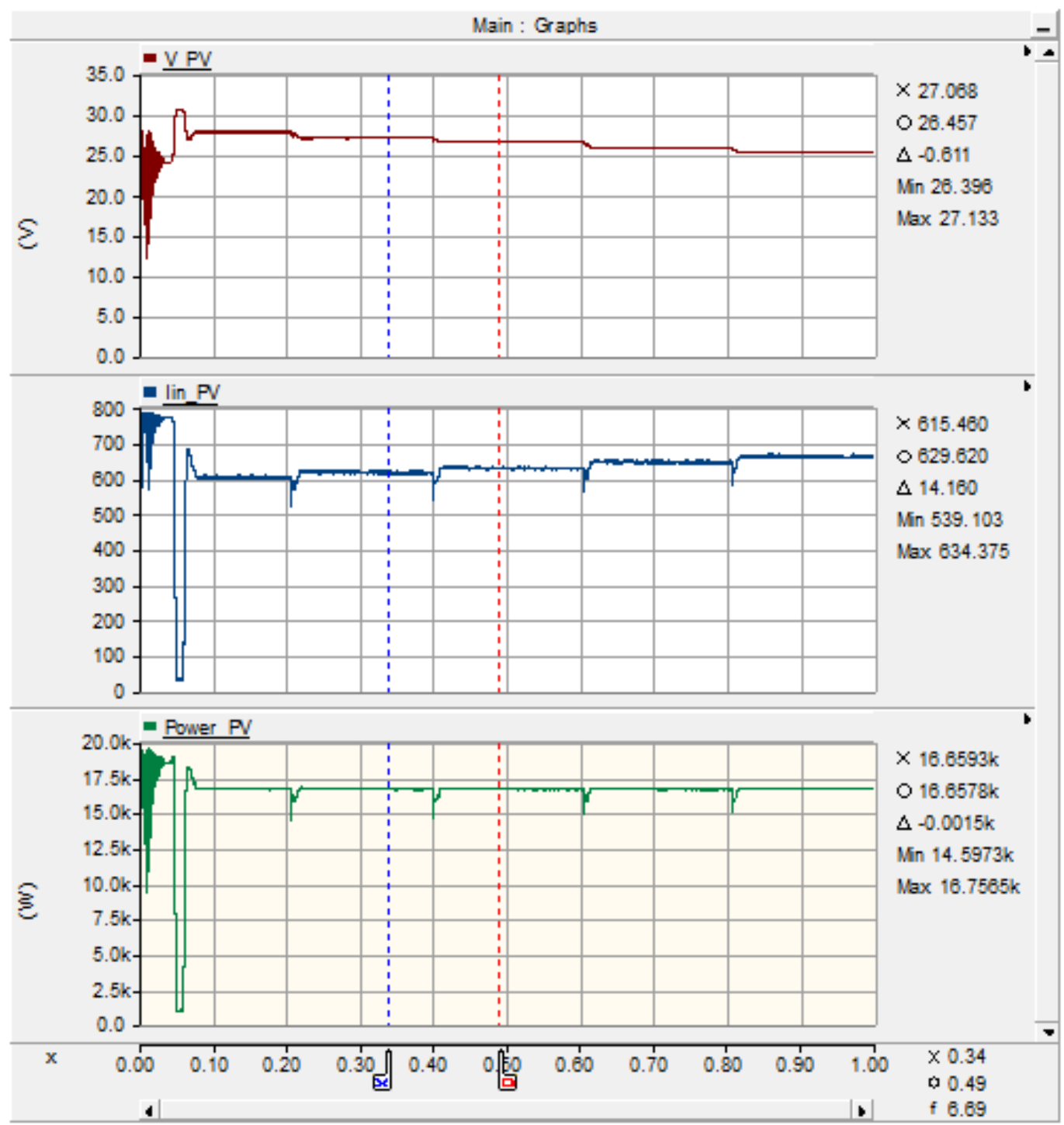

Figure 4-7: PV Array output Voltage (top), Current (middle), and Power (bottom) with Varying Temperature

Table 4-5: PV Output Voltage, Current, and Power with Varying Temperature

\begin{tabular}{|c|c|c|c|c|}
\hline Time (seconds) & Temperature $\left({ }^{\circ} \mathrm{C}\right)$ & Vmpp $(\mathrm{V})$ & $\begin{array}{c}\text { Current } \\
(\mathrm{A})\end{array}$ & Power $(\mathrm{kW})$ \\
\hline 0.1 & 5 & 27.6 & 608 & 16.8 \\
\hline 0.3 & 15 & 26.9 & 624 & 16.79 \\
\hline 0.5 & 25 & 26.3 & 638 & 16.8 \\
\hline 0.7 & 35 & 25.8 & 651 & 16.8 \\
\hline 0.9 & 45 & 25.15 & 668 & 16.8 \\
\hline
\end{tabular}


Table 4-1 summarizes the PV voltage, current, and power measurements with incrementing temperature. The voltage operating point of the PV array shifted to the left with increasing temperature as anticipated. The dips in the current and power graph represent the response time of the MPPT controller between the temperature change and the implementations of the necessary modifications to the Boost Converter's duty cycle.

For the second simulation test case, solar radiation is varied from $400 \mathrm{~W} / \mathrm{m}^{2}$ to $1000 \mathrm{~W} / \mathrm{m}^{2}$ in steps of $200 \mathrm{~W} / \mathrm{m}^{2}$, while temperature remains constant at $25^{\circ} \mathrm{C}$. The results of the simulation test case are shown in Figure 4-4. 


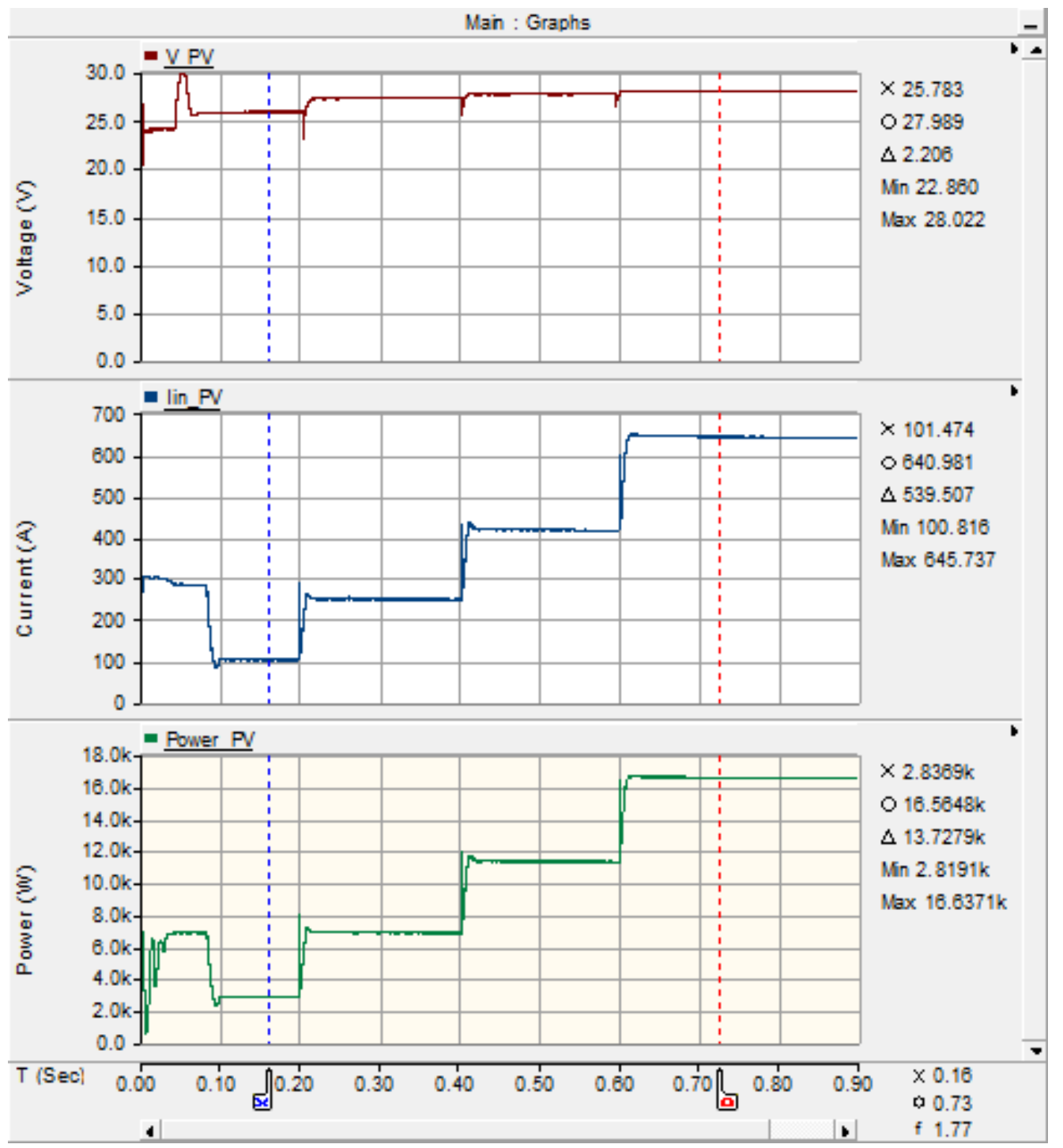

Figure 4-8: PV Array output Voltage (top), Current (middle), and Power (bottom) with Varying Solar Irradiance

Table 4-6: PV Output Voltage, Current, and Power with Varying Irradiance

\begin{tabular}{|c|c|c|c|c|}
\hline $\begin{array}{c}\text { Time } \\
(\text { seconds })\end{array}$ & $\begin{array}{c}\text { Irradiance } \\
\left(\mathrm{W} / \mathrm{m}^{2}\right)\end{array}$ & PV V & PV current (A) & PV power (kW) \\
\hline 0.15 & 400 & 25.9 & 109 & 2.83 \\
\hline 0.35 & 600 & 26.4 & 273 & 7.21 \\
\hline 0.55 & 800 & 27.1 & 428 & 11.6 \\
\hline 0.75 & 1000 & 27.8 & 604 & 16.8 \\
\hline
\end{tabular}


Table 4-2 summarizes the PV voltage, current and power measurements with incremented solar radiation. The power generating capability of the PV array increases with incrementing solar radiation. As the solar radiation is increased, PV array is able to generate more current and it voltage operating point moves slightly to the right as anticipated by Figure 4-2.

For the third simulation test case, the load is varied while the other two parameters remain constant at $800 \mathrm{~W} / \mathrm{m}^{2}$ and $25^{\circ} \mathrm{C}$. Figure $4-5$ shows that when the load is increased, the voltage operating point shifts to the left on the I-V curve. Figure 4-6 shows the results from the third simulation test case where the load of the individual DC house is varied from $100 \mathrm{~W}$ to $500 \mathrm{~W}$ in steps of $100 \mathrm{~W}$. As expected, the PV voltage drops as its output power increases.

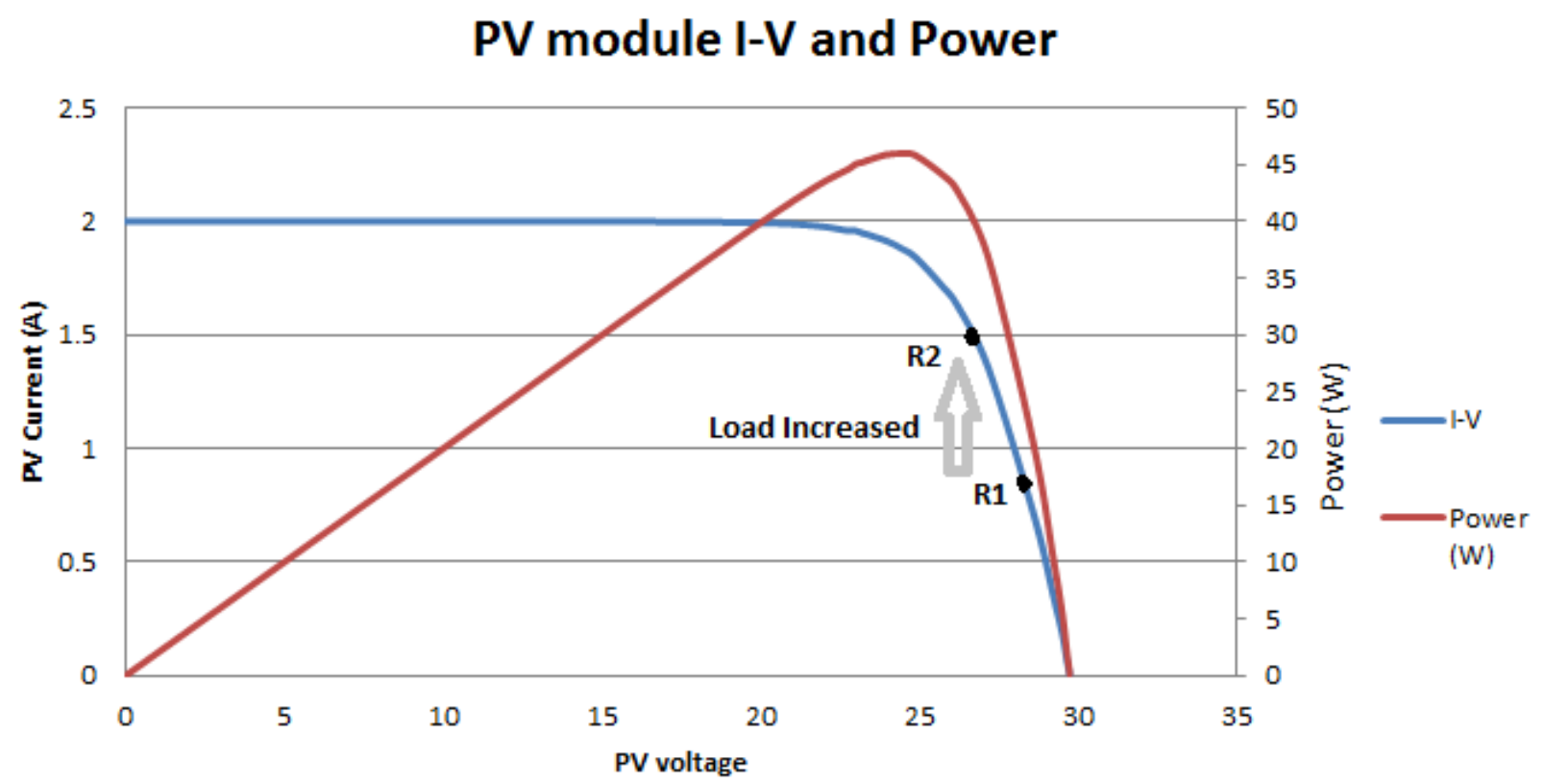

Figure 4-5: PV Array Voltage Operating Point as the Load Increases 


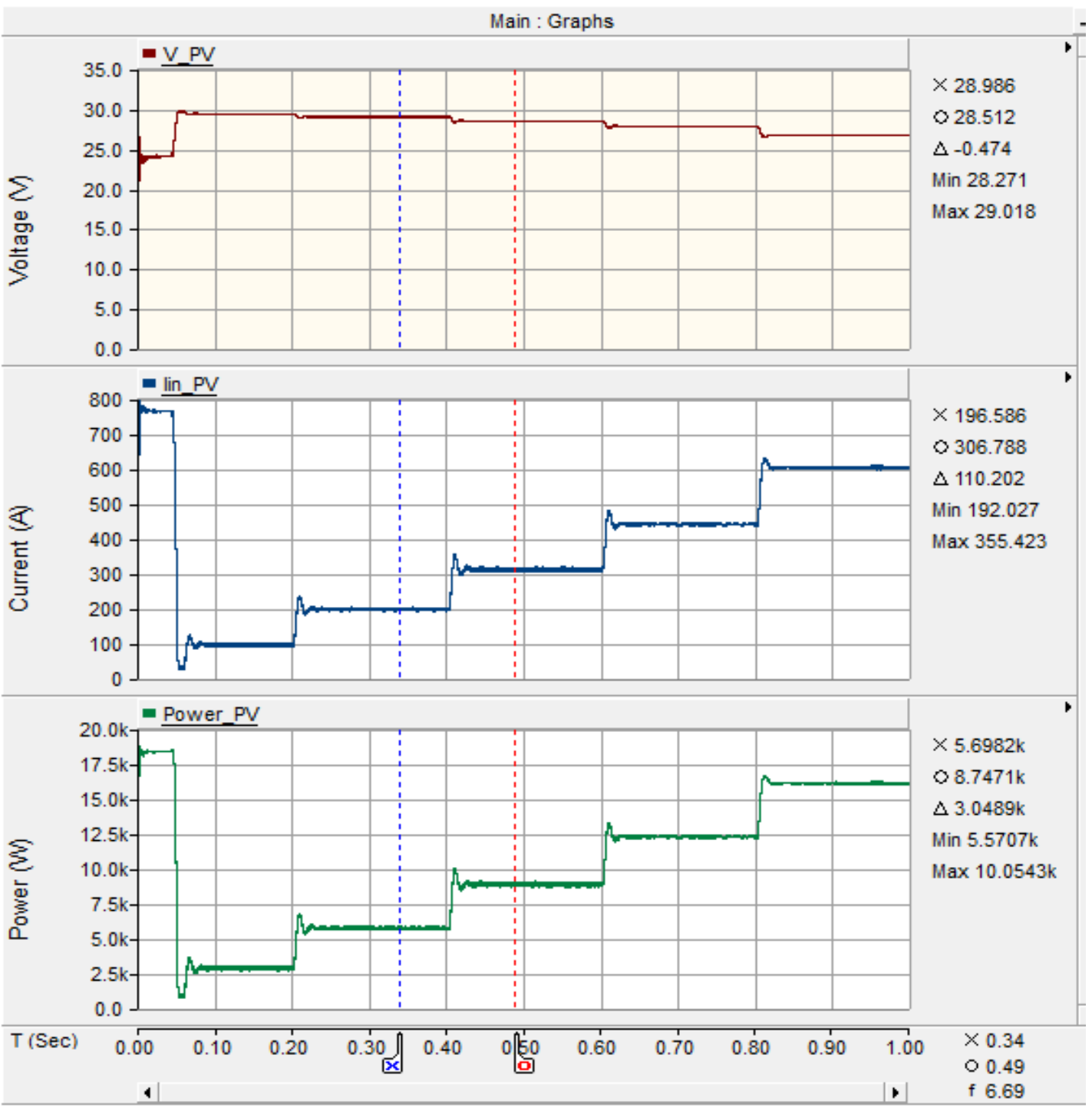

Figure 4-6: PV Array operating Voltage (top), Current (middle), and Power (bottom) with Varying Load

Table 4-3: PV Output Voltage, Current and Power with Varying Load

\begin{tabular}{|c|c|c|c|c|}
\hline Time (seconds) & House Load (W) & Vmpp (V) & $\begin{array}{c}\text { Current } \\
(\mathrm{A})\end{array}$ & Power (kW) \\
\hline 0.15 & 100 & 29.37 & 95 & 2.8 \\
\hline 0.25 & 200 & 28.98 & 196 & 5.68 \\
\hline 0.45 & 300 & 28.46 & 318 & 9.05 \\
\hline 0.65 & 400 & 27.85 & 442 & 12.31 \\
\hline 0.85 & 500 & 26.70 & 614 & 16.4 \\
\hline
\end{tabular}


Data from Table 4-3 show that the $\mathrm{V}_{\mathrm{mpp}}$ (operating point of the PV array) moves to the left with increasing load as predicted.

Figure 4-7 depicts the input (PV voltage) and output voltage of the Boost Converter as the load is increased at standard operating conditions $\left(800 \mathrm{~W} / \mathrm{m}^{\wedge} 2 @ 25^{\circ} \mathrm{C}\right)$. The output voltage of the Boost Converter is dependent upon its duty cycle, which is controlled by the MPPT controller. Table 4-4 summarizes the input and output voltages and duty cycle of the Boost Converters. The duty cycle of the converter is calculated according to equation 4-1. The duty cycle of the converter decreases as the load increases which accounts for more power transferred to the output. 


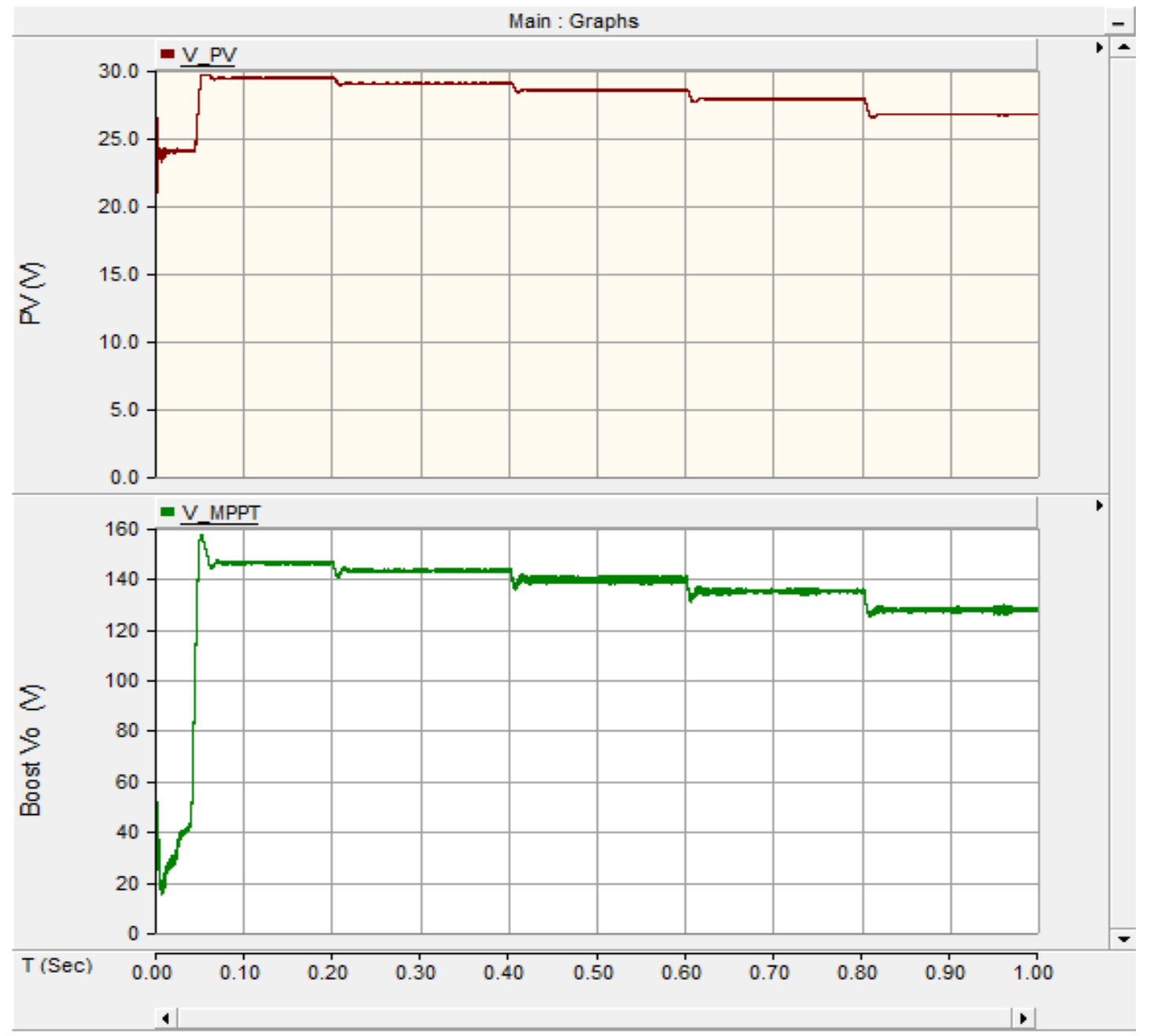

Figure 4-7: Boost Converter Input and Output Voltages with increasing Load

Table 4-4: Summary of the Boost Converter Voltages and Duty Cycle with Increasing Load

\begin{tabular}{|c|c|c|c|c|}
\hline Time (seconds) & Load & Vmpp (V) & Boost Vo (V) & Duty Cycle (\%) \\
\hline 0.15 & 100 & 29.37 & 147.3 & 80.1 \\
\hline 0.25 & 200 & 28.98 & 143.9 & 79.9 \\
\hline 0.45 & 300 & 28.46 & 139.29 & 79.56 \\
\hline 0.65 & 400 & 27.85 & 134.47 & 79.29 \\
\hline 0.85 & 500 & 26.70 & 126.4 & 78.87 \\
\hline
\end{tabular}

$$
\% \text { Duty Cycle } \text { Boost }=\left(1-\frac{V_{P V}}{V_{\text {oBoost }}}\right) \times 100 \%
$$


The Continuous Conduction mode of the converter is verified by Figure 4-8. The top graph (Figure 4-8) shows the increasing current through the inductor as the load increases. The bottom graph displays a magnified view of the charging and discharging of the inductor at full load $(500 \mathrm{~W})$. The inductor is charging for approximately $80 \%$ of the total period and discharging for about $20 \%$ of the total period as it was calculated from the input and output voltages of the converter (Table 4-4). Next, the operation of the Buck Converter is verified.

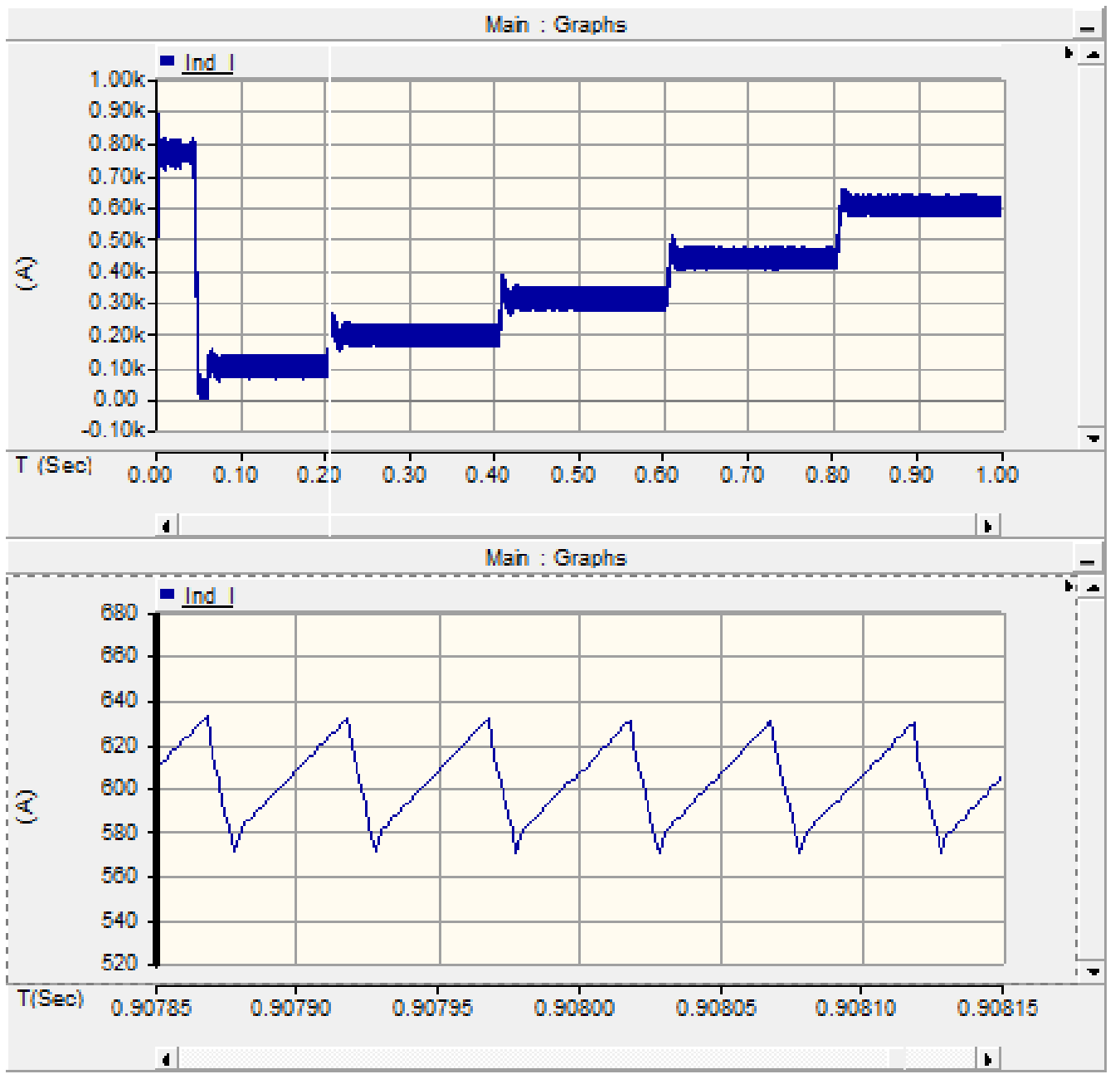

Figure 4-8: Boost Converter Inductor Current (top) and Magnified View of Inductor Current at Full Load (bottom) 


\section{2: Buck Converter Validation}

The Buck converter needs to step-down its input voltage (which is the output voltage of the Boost Converter) to 48V DC bus voltage. Thus, the Buck Converter's output is dynamically regulated at $48 \mathrm{~V}$ by the PI controller. Figure $4-9$ depicts the input and output voltages of the Buck Converter with increasing load. The graph data is summarized in Table 4-5 and verify that the Buck Converter is regulating its output voltage at $48 \mathrm{~V}$ (also the DC bus voltage) with varying input voltage as might be the case in many situations.

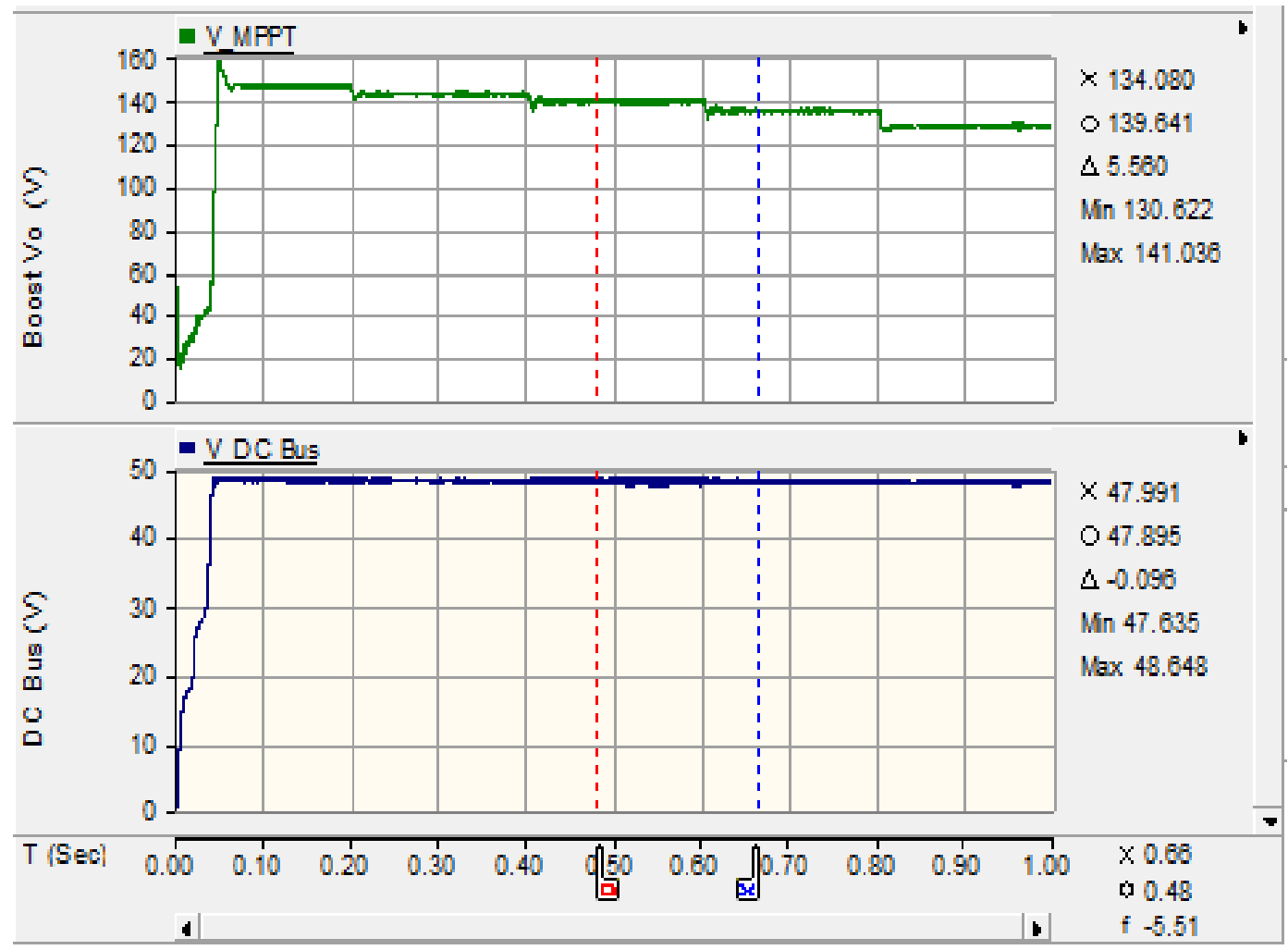

Figure 4-9: Buck Converter Input and Output Voltages with increasing Load 
Table 4-5: Summary of the Buck Converter Voltages and Duty Cycle with Increasing Load

\begin{tabular}{|c|c|c|c|c|}
\hline Time (seconds) & Load & $\begin{array}{c}\text { Buck Vin or } \\
\text { Boost Vo (V) }\end{array}$ & $\begin{array}{c}\text { Buck Vo or } \\
\text { DC Bus (V) }\end{array}$ & Duty Cycle (\%) \\
\hline 0.15 & 100 & 147.3 & 48.38 & 32.84 \\
\hline 0.25 & 200 & 143.9 & 48.26 & 33.54 \\
\hline 0.45 & 300 & 139.29 & 48.15 & 34.57 \\
\hline 0.65 & 400 & 134.47 & 48.06 & 35.74 \\
\hline 0.85 & 500 & 126.4 & 48.02 & 37.99 \\
\hline
\end{tabular}

$$
\% \text { Duty Cycle } \text { Buck }=\left(\frac{V_{o}}{V_{\text {in }}}\right) \times 100 \%
$$

Figure 4-10 illustrates the output power of the PV array and the output power of the Buck Converter. Table 4-6 summarizes the data from the power graphs and the efficiency of the converter is calculated according to equation 4-3. The efficiency of the converter increases with increasing load as expected except at the full load.

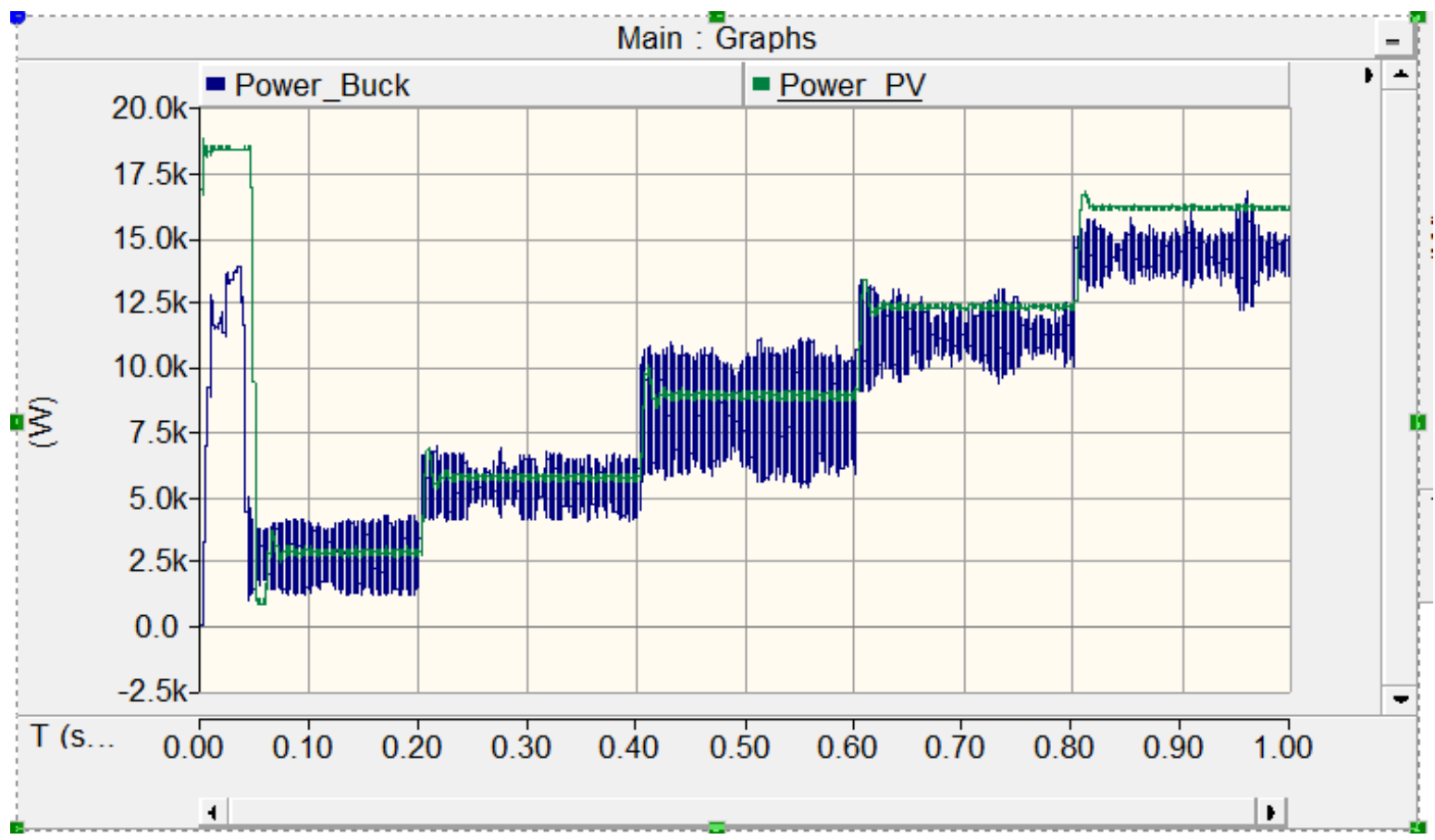

Figure 4-10: PV Output Power (green) and Buck Converter Output Power (blue) with Varying Load 
Table 4-6: Efficiency Summary of the Buck and Boost Converters with Increasing Load

\begin{tabular}{|c|c|c|c|c|}
\hline Time (seconds) & Load $(\mathrm{kW})$ & PV Pout $(\mathrm{kW})$ & Buck Pout $(\mathrm{kW})$ & Efficiency (\%) \\
\hline 0.1 & 2.5 & 2.96 & 2.63 & 88.85 \\
\hline 0.3 & 5 & 5.85 & 5.3 & 91.45 \\
\hline 0.5 & 7.5 & 8.87 & 8.2 & 92.45 \\
\hline 0.7 & 10 & 12.1 & 11.31 & 93.47 \\
\hline 0.9 & 12.5 & 16.01 & 14.8 & 92.44 \\
\hline
\end{tabular}

$$
\text { Efficiency }=\frac{\text { Buck } P_{\text {out }}}{P V P_{\text {out }}} \times 100 \%
$$

\section{3: Voltage Stability of the Distribution Network}

Figure 4-11 depicts the centralized power distribution model of the 25 houses. As mentioned in the previous chapter, the resistors in the layout represent the DC resistances of the cable conductors. The farthest house in the layout will see the maximum voltage drop due to the resistive loses of the conductors. Therefore, the Boost Converters are needed to boost the decreased bus voltage back to $48 \mathrm{~V}$ before it can be distributed to the DC Houses. Next, voltage drop and stability of the distribution layout is tested under different operating conditions. 


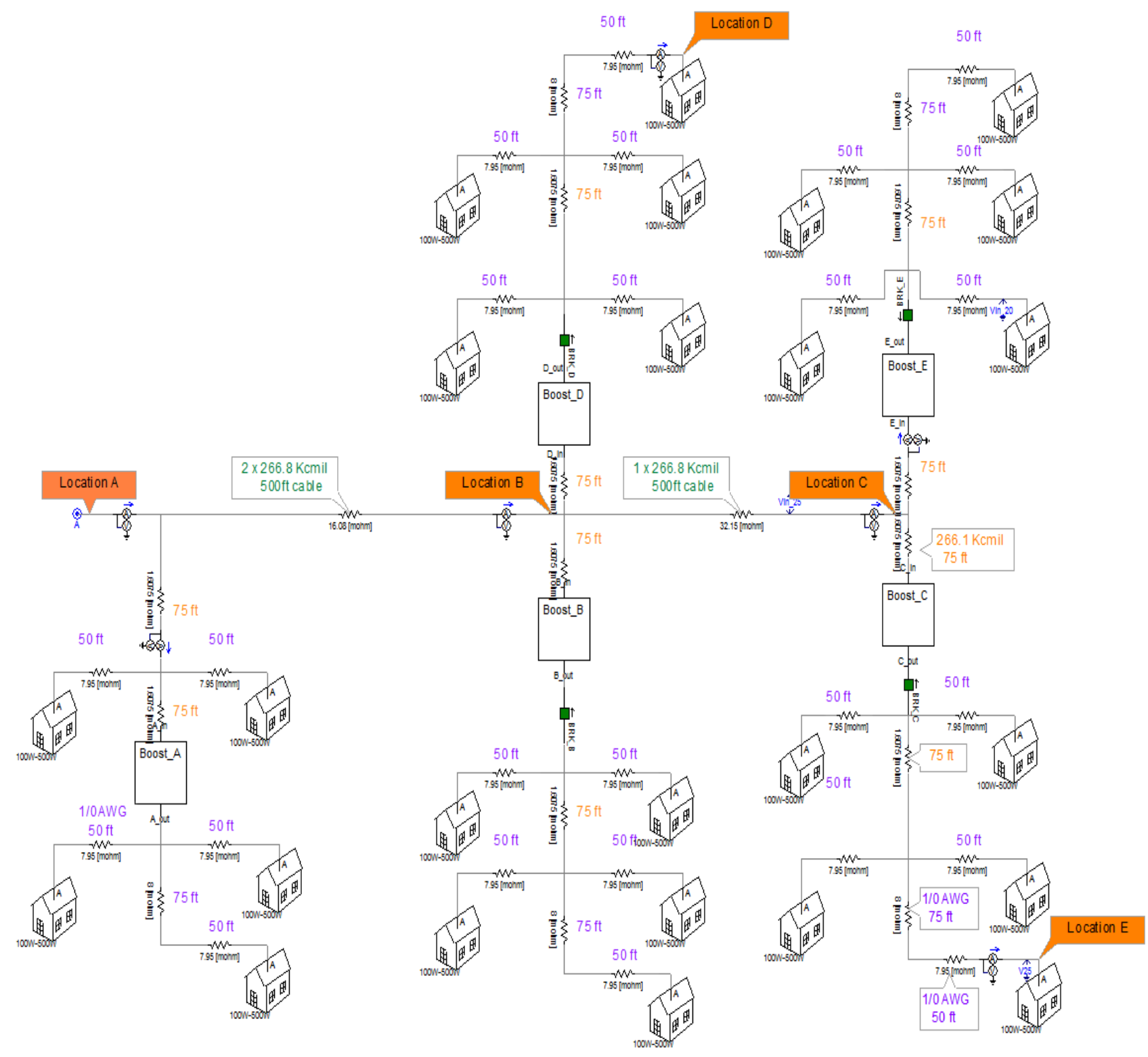

Figure 4-11: Centralized Distribution Network Design for 25 DC Houses 


\subsection{1: Full Load}

Figure 4-12 illustrates the voltages at five different locations when the system is operating at full load (500W) and PV array is generating power at standard operating conditions $\left(800 \mathrm{~W} / \mathrm{m}^{\wedge} 2\right.$ and $\left.25^{\circ} \mathrm{C}\right)$.

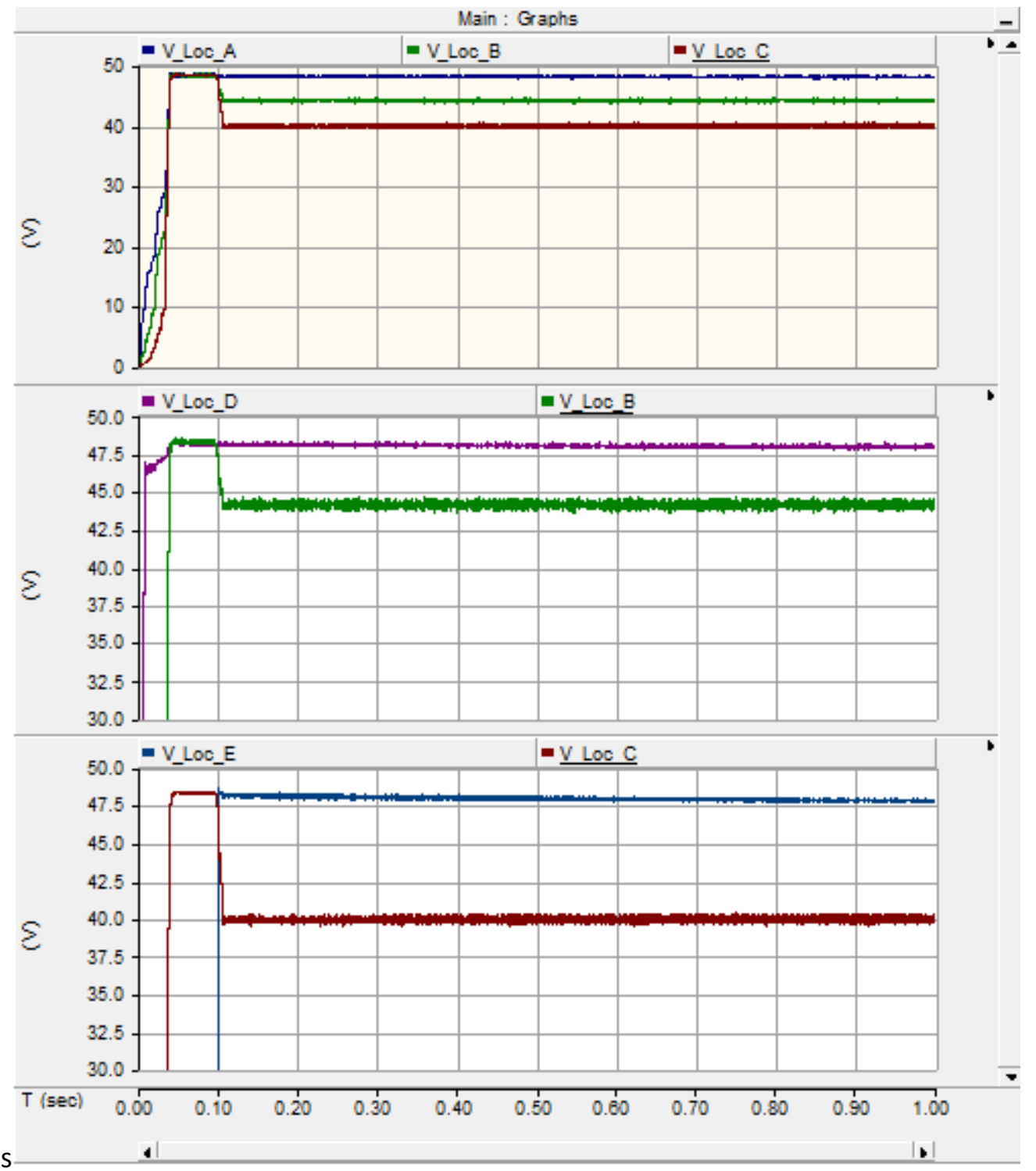

Figure 4-12: Voltages at Five locations in the Distribution Network at Full Load 
The top graph (Figure 4-12) shows voltages across the main distribution conductor. The voltage at location A (which is at same location as source) is averaging around $48.7 \mathrm{~V}$. Location B is $500 \mathrm{ft}$ away from the main source. Two Waxwing $(2 \times 266.1$ kcmil) conductors are used to transmit power across this distance. There is a $4 \mathrm{~V}$ drop across the Waxwing conductors due to its DC resistance, and the voltage at location B is $44 \mathrm{~V}$. Location $\mathrm{C}$ is at 500ft from location B and only one Waxwing $(1 \times 266.1 \mathrm{kcmil})$ is used to transmit power across this distance because it carries only about half as much current as the first conductors. Moreover, the voltage at location $\mathrm{C}$ is around $40 \mathrm{~V}$. This portrays that these voltage drops are dependent upon three variables: distance, load, and cable resistance.

The middle graph (Figure 4-12) depicts the voltage difference between Location B (beginning of Feeder D) and the voltage supplied to the individual house at location D (at the end of the Feeder D). The voltage from location B is boosted back to $48 \mathrm{~V}$ by the Boost Converter and distributed to the DC Houses in Feeder D. Similarly, voltage at location C is boosted back to $48 \mathrm{~V}$ and is distributed to the DC Houses in Feeder C, as depicted in bottom graph of Figure 4-12.

Figure 4-13 shows the current in the main conductors and into the two individual houses at Locations D and E. As anticipated location A conducts the maximum current of about $310 \mathrm{~A}$, followed by location B current of about $260 \mathrm{~A}$, and then the current at location $\mathrm{C}$ is about $130 \mathrm{~A}$. The individual houses are supplied with $10.4 \mathrm{~A}$, which proves that they are consuming about $500 \mathrm{~W}$ when operating at $48 \mathrm{~V}$. The current ripple significantly depends on the inductor value of the Buck Converter (on the source side). 
The inductor with lower value closer to the boundary conduction mode leads to higher ripple in the system.

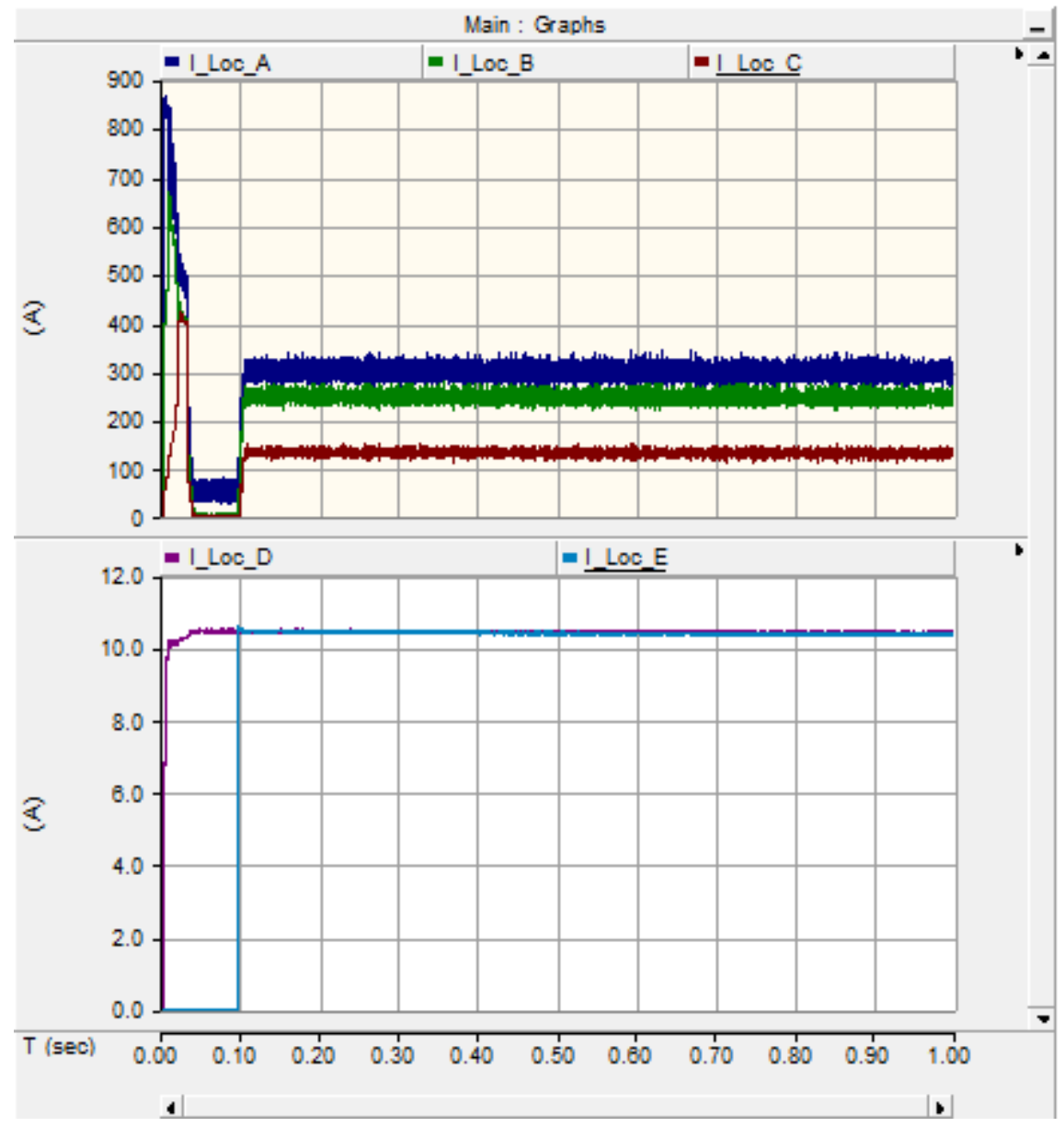

Figure 4-13: Current at Five Locations in the Distribution Network at Full Load

Figure 4-14 depicts the power flow in the distribution network. The bottom graph (Figure 4-14) validates that the individual houses are consuming about 500W. In the steady state (around .2 seconds), the source is supplying approximately $14.6 \mathrm{~kW}$ and all of the houses combined are consuming little over $12.5 \mathrm{~kW}$. So, approximately $2 \mathrm{~kW}$ of 
power is consumed by the distribution network, mainly by the losses in the distribution cables. These losses can be minimized by decreasing the distance if possible, or by using higher gauge cables which will have less resistance.

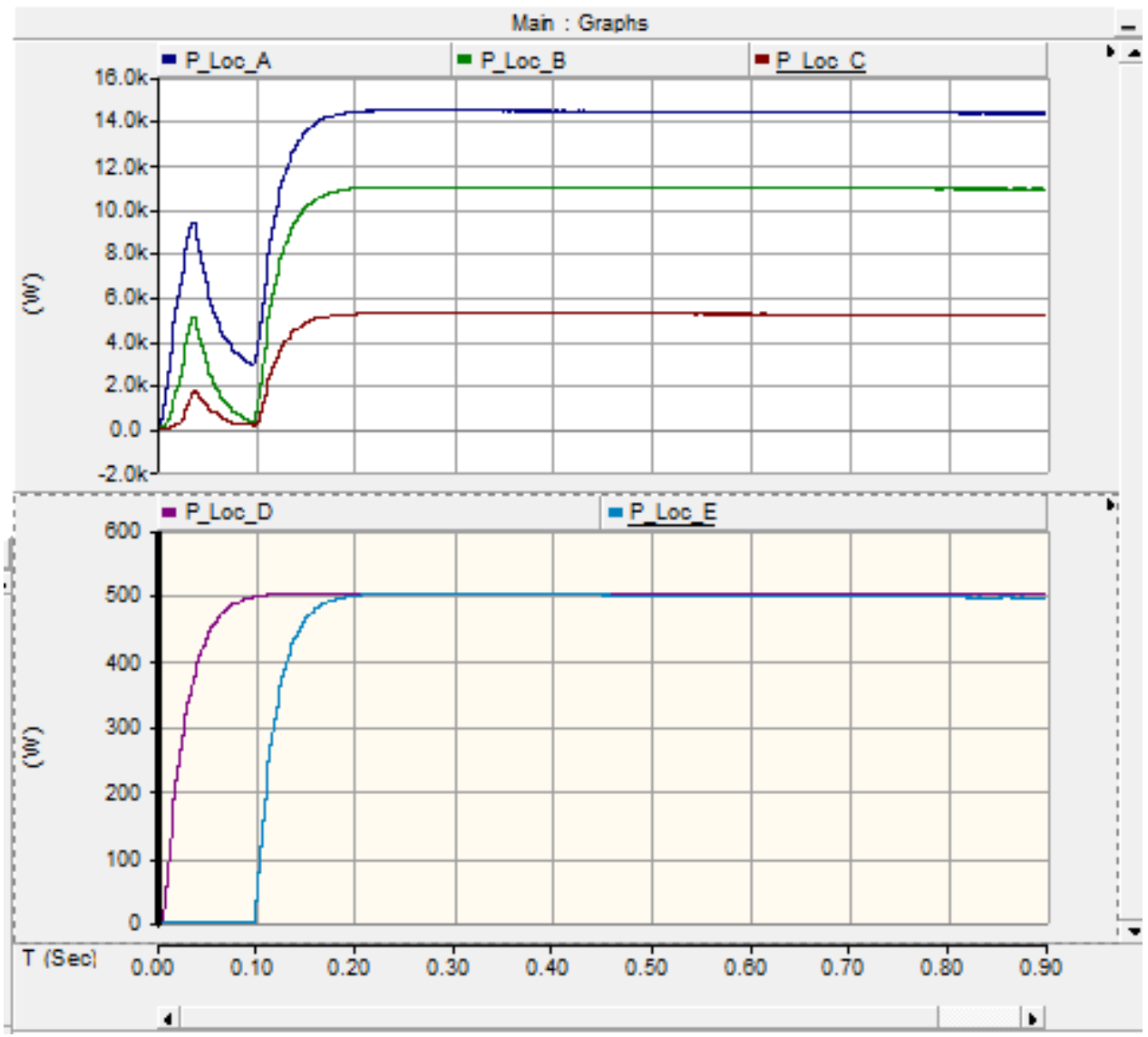

Figure 4-14: Power in the main DC Distribution Cable (Top) and Power delivered to 2 individual Houses (bottom) 


\subsection{2: Varying Load}

In the second simulation test, the house load is incremented from $100 \mathrm{~W}$ to $500 \mathrm{~W}$ in steps of 50W every 0.1 seconds. Figure 4-15 illustrates voltage measurements of the network as the load is varied. Higher load yields higher current in the system which contributes to higher voltage drops across the distribution conductors $\left(\mathrm{V}_{\text {drop }}=\mathrm{I}^{*} \mathrm{R}_{\text {cable }}\right)$.

However, the dynamic response of the Boost Converters keeps the distributed house voltage close to $48 \mathrm{~V}$ ( $\pm 0.5 \mathrm{~V}$ ) consistently, as depicted on the bottom two graphs of Figure 4-15.

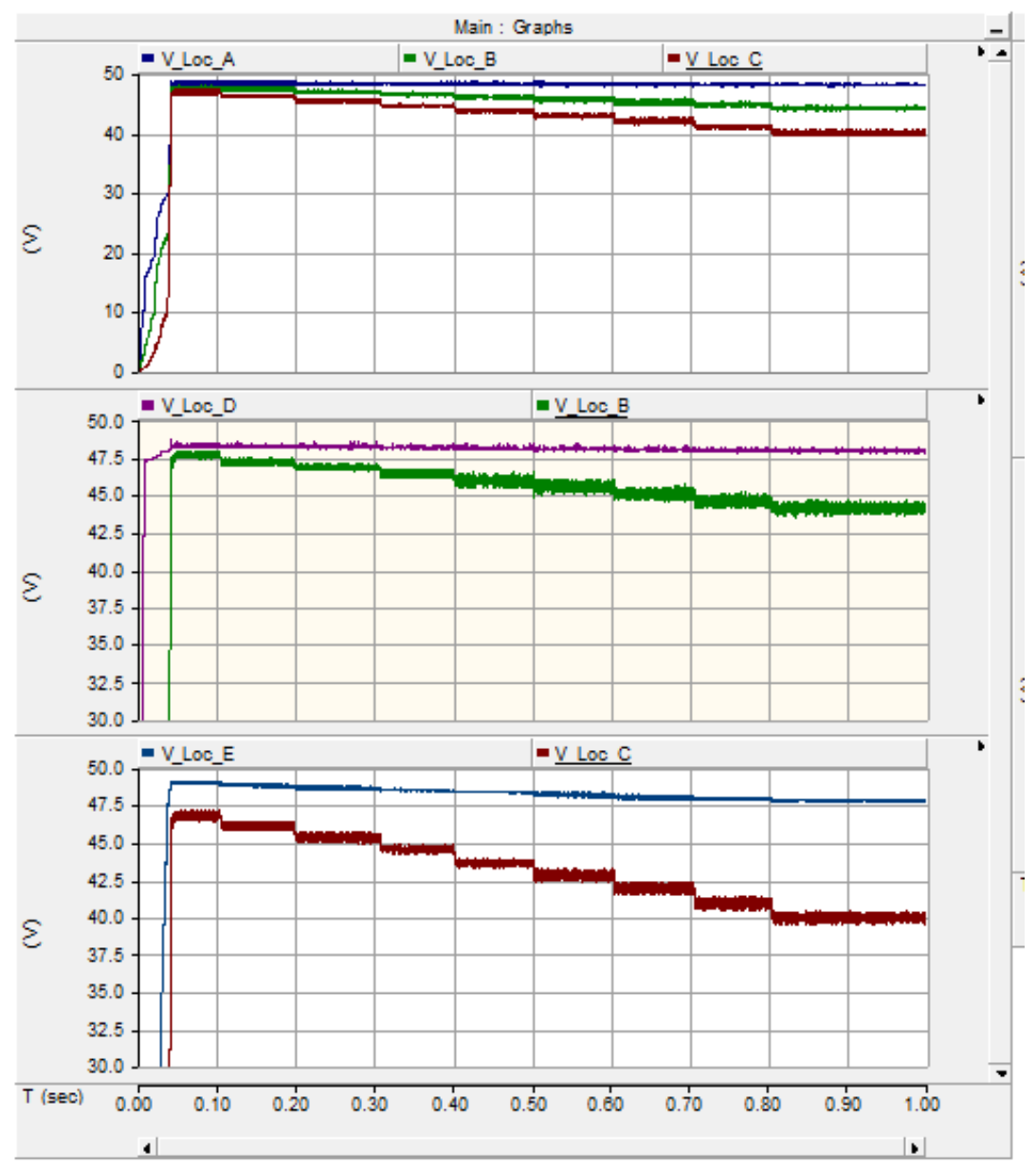

Figure 4-15: Voltage Measurements as Load is incremented from $100 \mathrm{~W}$ to $500 \mathrm{~W}$ in steps of $50 \mathrm{~W}$ 
The current flow in the system increases in accordance with the load, as depicted in Figure 4-16. The current ripple increases as the amount of current in the system increases.

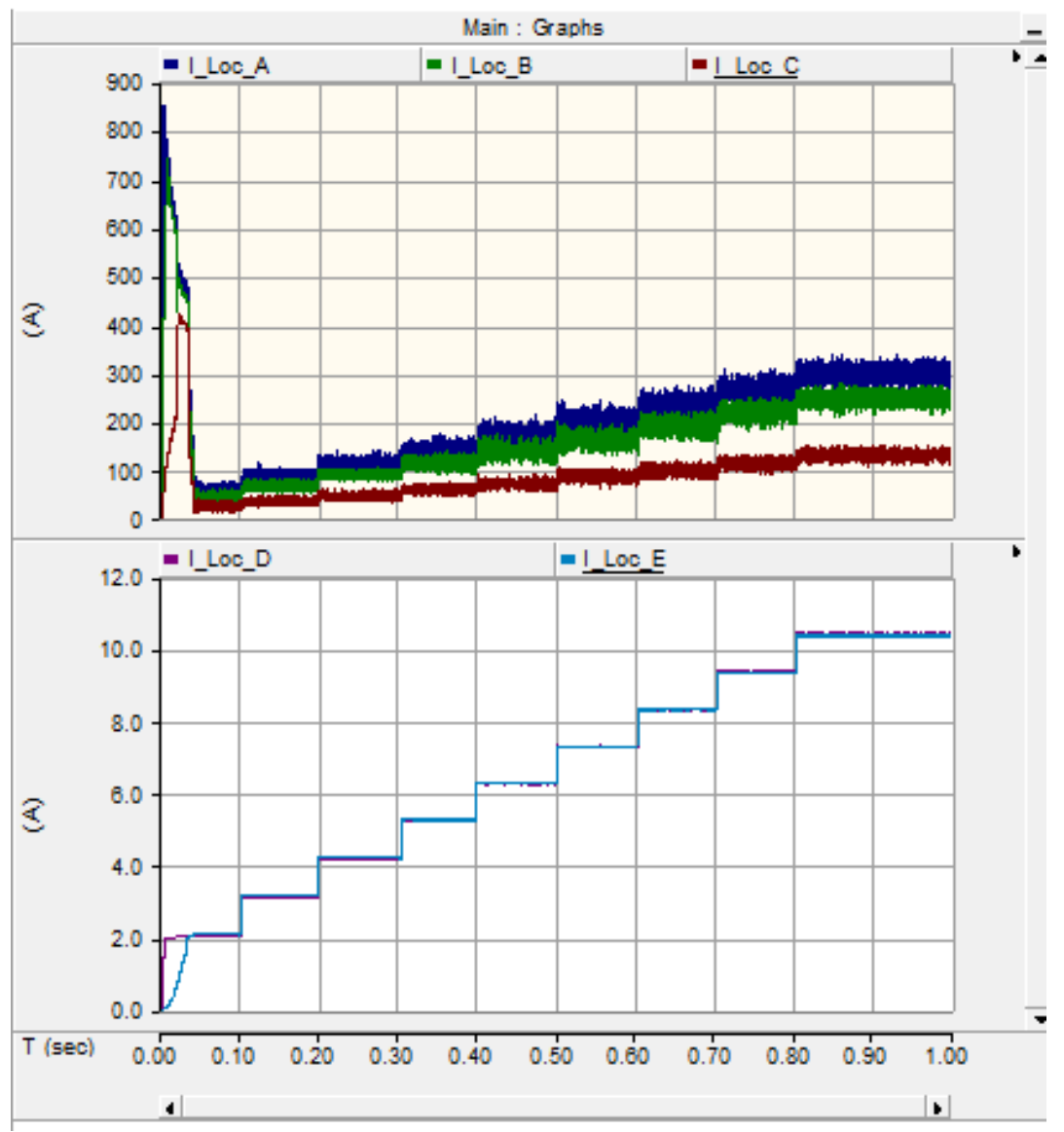

Figure 4-16: Current Measurements at Five Locations as load is incremented from 100W to 500W in steps of $50 \mathrm{~W}$

Figure 4-17 depicts the power flow increases with the increasing load. The losses in the distribution network increase as well with the increasing current $\left(\mathrm{P}_{\text {loss }}=\mathrm{I}^{2} * \mathrm{R}_{\text {cable }}\right)$. Next, the number of houses operating at full load is incremented from 5 to 25 in step of 5 . 


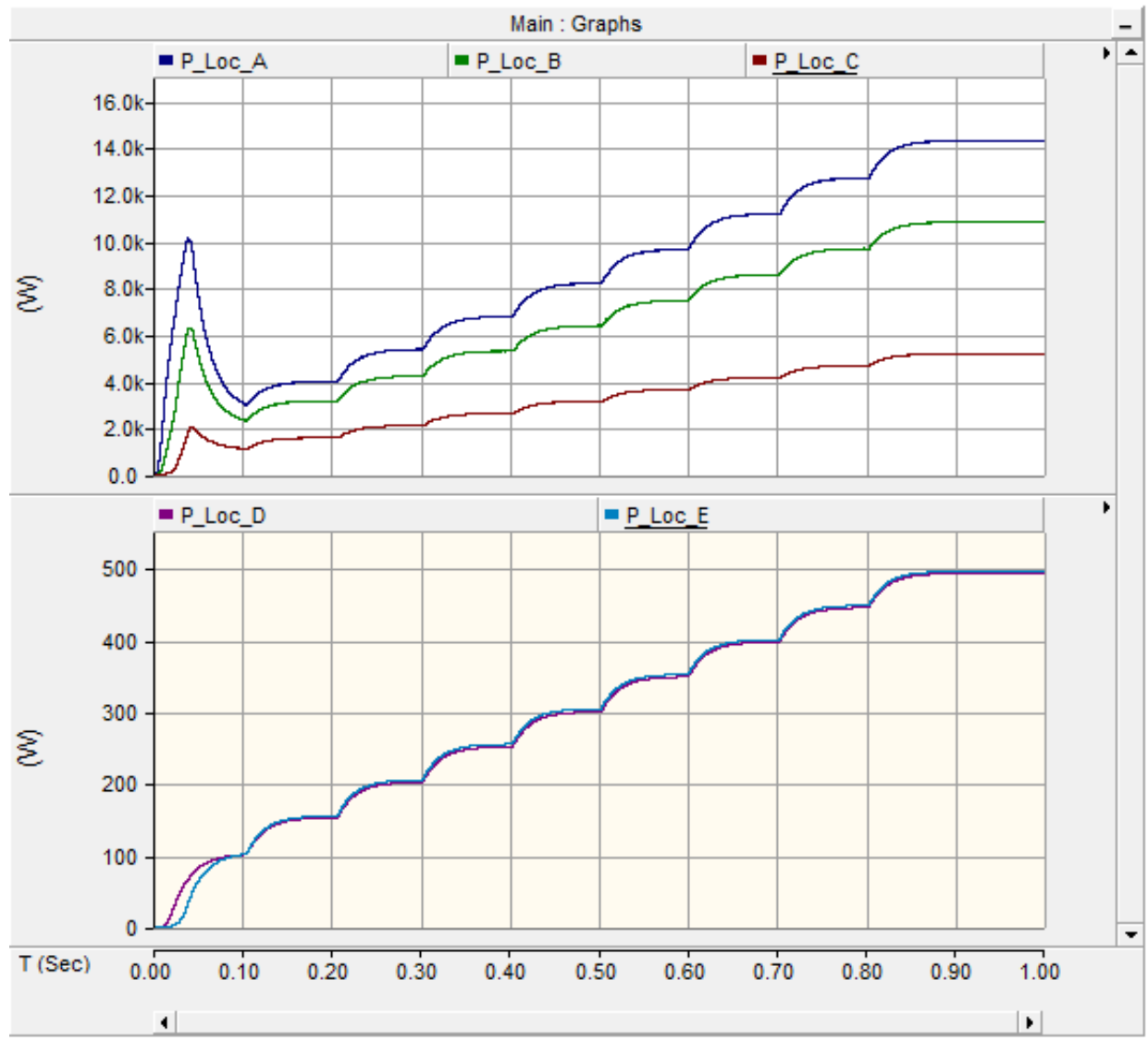

Figure 4-17: Power measurements at 5 different locations as load incremented from $100 \mathrm{~W}$ to $500 \mathrm{~W}$ in steps of $50 \mathrm{~W}$

\subsection{3: Varying Number of Houses Operating}

Figure 4-18 shows voltage stability in the network as the number of houses consuming power at full load is increased from 5 to 25 in steps of 5. Table 4-7 summarizes the voltage measurements at the five locations in the system. The current in the system increases in accordance with the number of houses consuming power, which leads to the voltage drops at locations B and C. These voltage drops are compensated by the Boost Converters and the voltage at locations D and $\mathrm{E}$ is kept stable at $48 \mathrm{~V}$. 
Similarly, Figure 4-19 and 4-20 show the current and power flow in the system with five houses added to the network every 0.2 seconds.

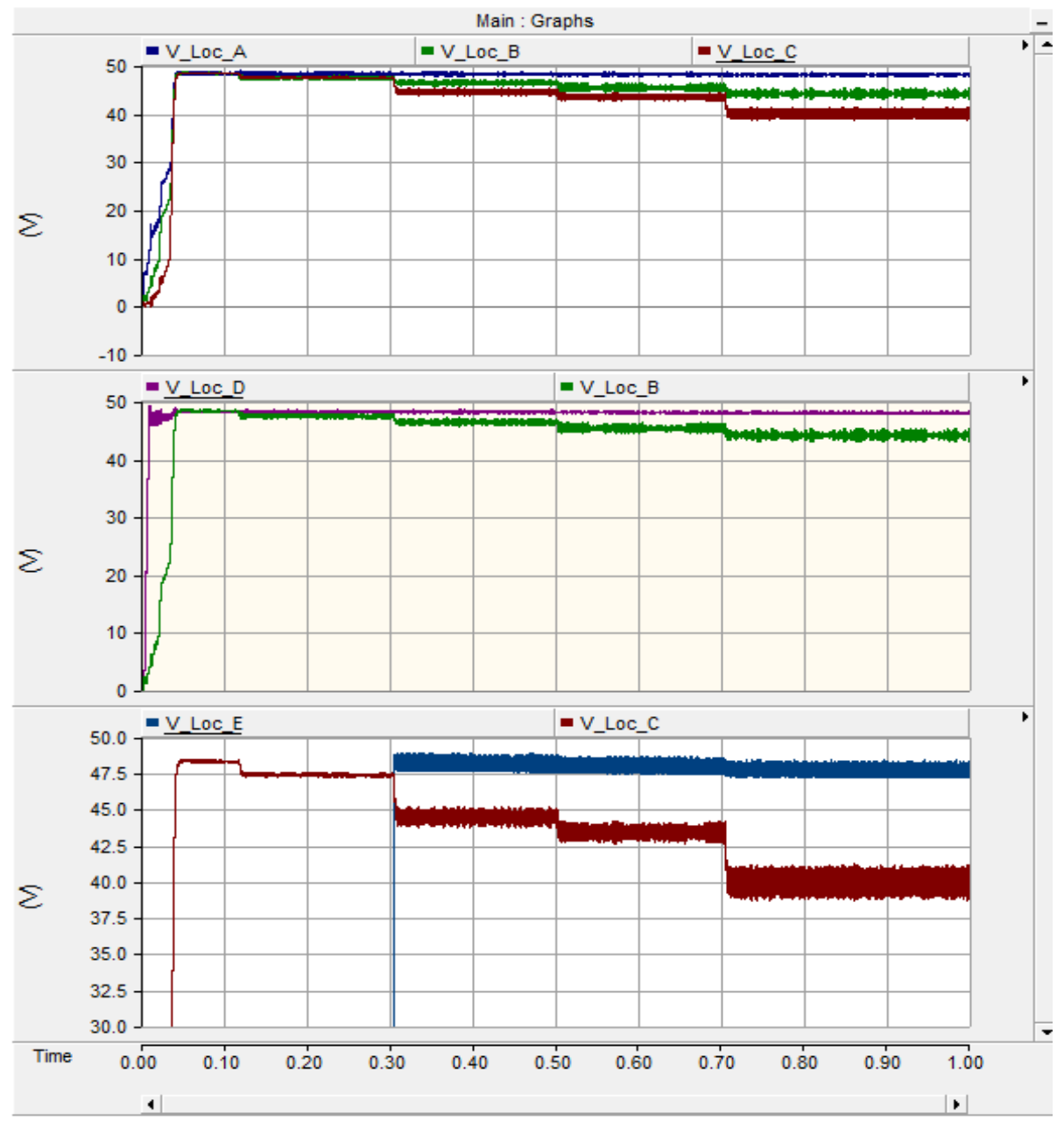

Figure 4-18: Voltage Measurements at Five Locations as Number of Houses is incremented

Table 4-7: Distribution Network Voltages with 5 to 25 Houses at 500W

\begin{tabular}{|c|c|c|c|c|c|c|}
\hline Time $(\mathrm{sec})$ & Houses & $\begin{array}{c}\text { Location A } \\
(\mathrm{V})\end{array}$ & $\begin{array}{c}\text { Location B } \\
(\mathrm{V})\end{array}$ & $\begin{array}{c}\text { Location C } \\
(\mathrm{V})\end{array}$ & $\begin{array}{c}\text { Location D } \\
(\mathrm{V})\end{array}$ & $\begin{array}{c}\text { Location E } \\
(\mathrm{V})\end{array}$ \\
\hline 0.1 & 5 & 48.7 & 48.2 & 48.2 & 48.4 & 48.3 \\
\hline 0.2 & 10 & 48.5 & 47.1 & 47.5 & 48.2 & 48.2 \\
\hline 0.4 & 15 & 48.2 & 46.2 & 44.5 & 48.1 & 48 \\
\hline 0.6 & 20 & 48 & 45.2 & 43.1 & 47.9 & 47.9 \\
\hline 0.8 & 25 & 47.8 & 44.1 & 40.1 & 47.8 & 47.7 \\
\hline
\end{tabular}




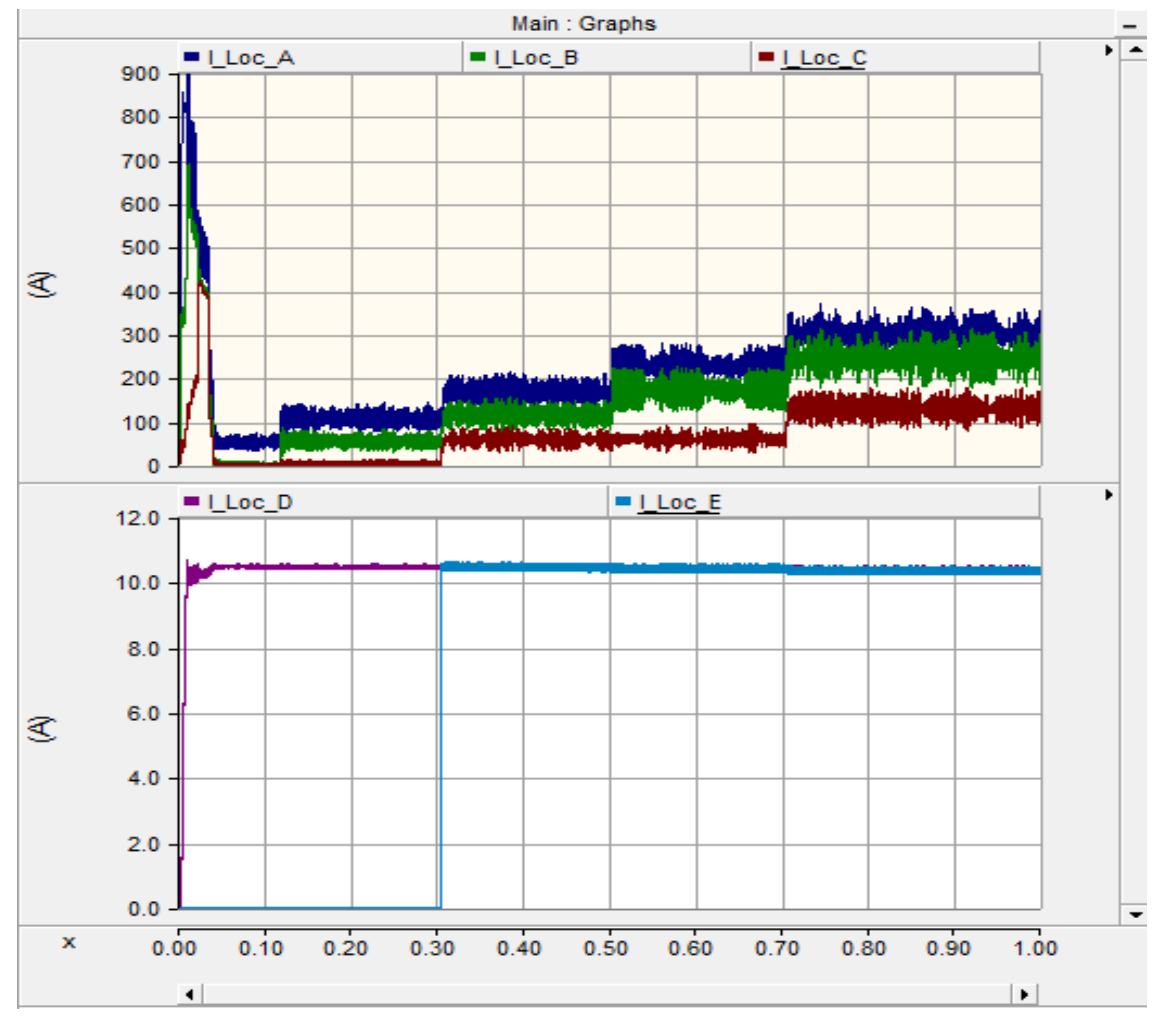

Figure 4-19: Current Measurements at Five Locations as Number of Houses is incremented

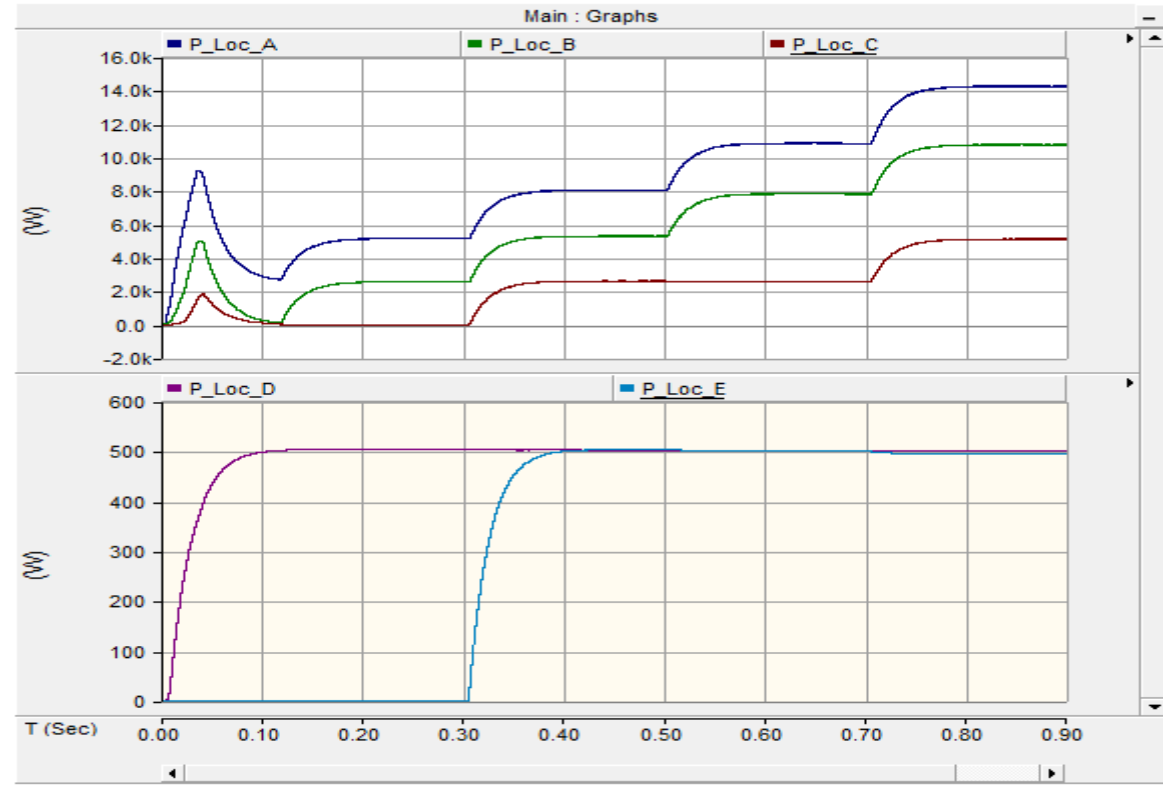

Figure 4-20: Power Measurements at Five Locations as Number of Houses is incremented 


\section{4: PV Charging the Battery and Supplying the Load}

Figure 4-21 illustrates the peak sun hour power generation capacity of the PV source. During the peak sun hours, the PV array produces more power than the load demands and this excess power is used to charge the battery bank.

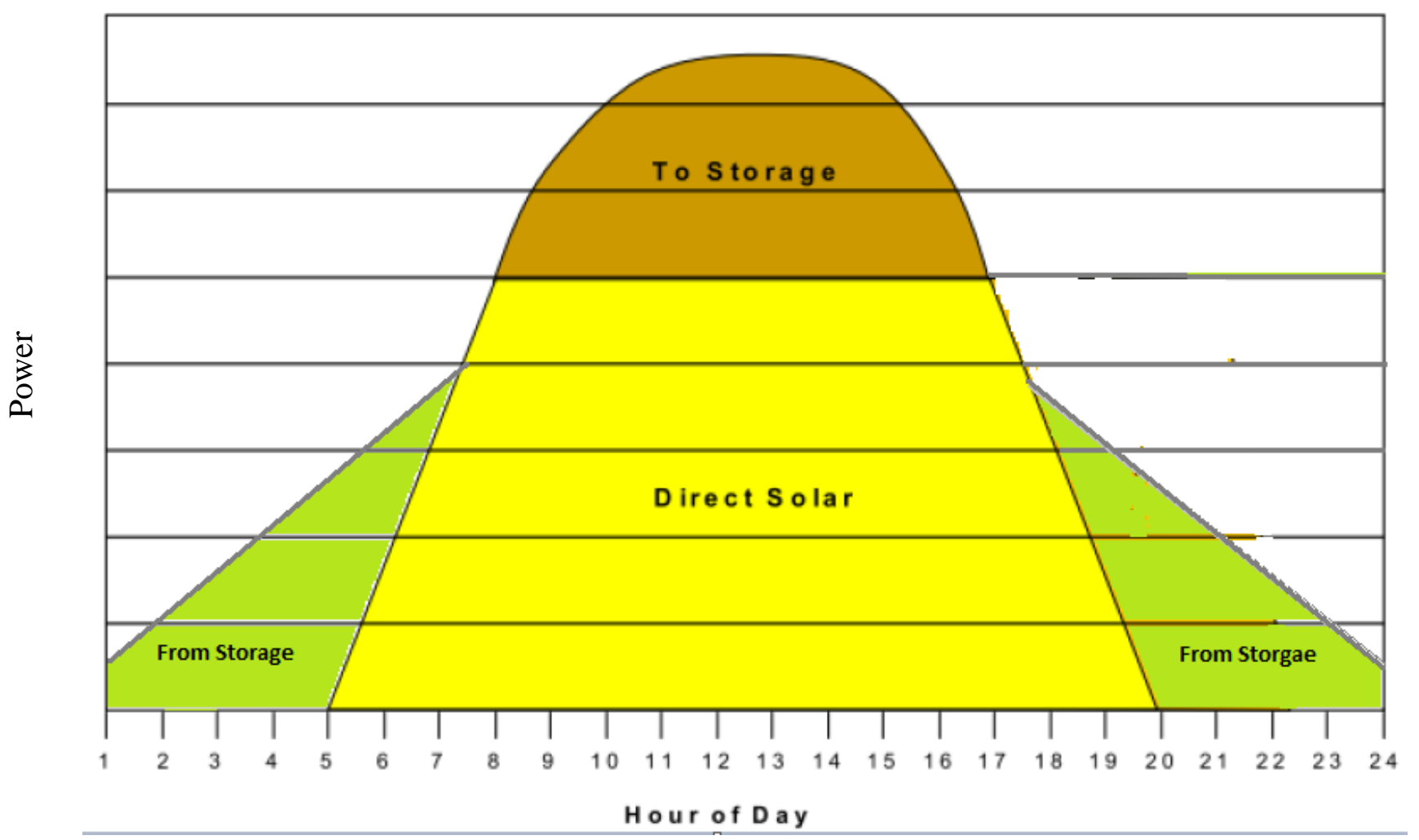

Figure 4-21: Battery Storage during Peak Sun Hours (dark yellow) and Battery Supplying Load (green)

For night time operation (approximately14 hours of non-generation period), battery bank will require approximately $48 \mathrm{kWh}$ of energy in order to supply the DC houses, which will consume 100W-150W each. A test case is run where the excess power from the PV array during peak sun hours is used to charge the battery bank. Figure 4-22 shows that $6.8 \mathrm{~kW}$ of energy is supplied to the battery and at this rate, 7 peak sun hours 
will provide the battery bank with enough energy to last through the night time. Figure 423 illustrates the battery current and voltage.

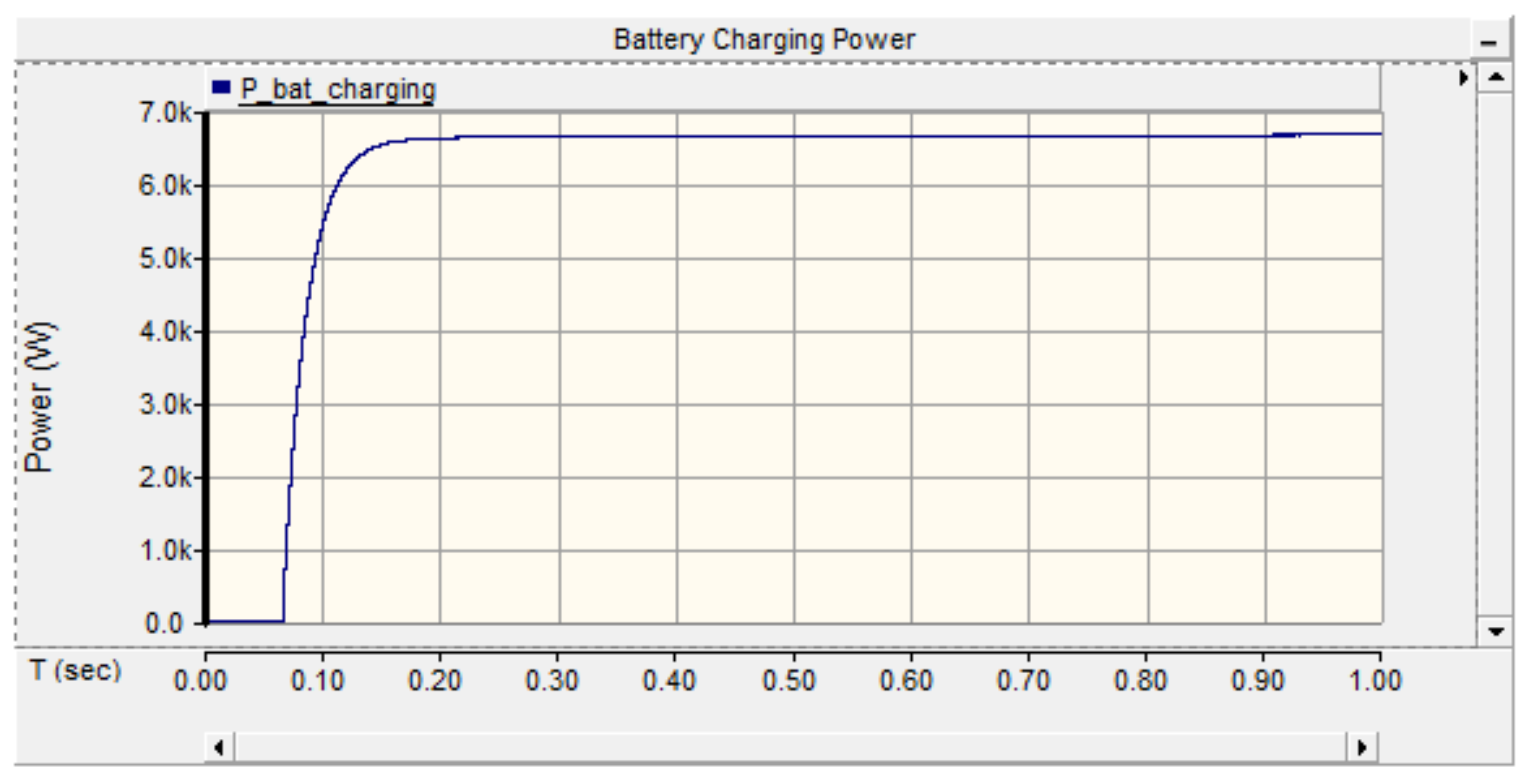

Figure 4-22: Power Supplied to the Battery from PV Array

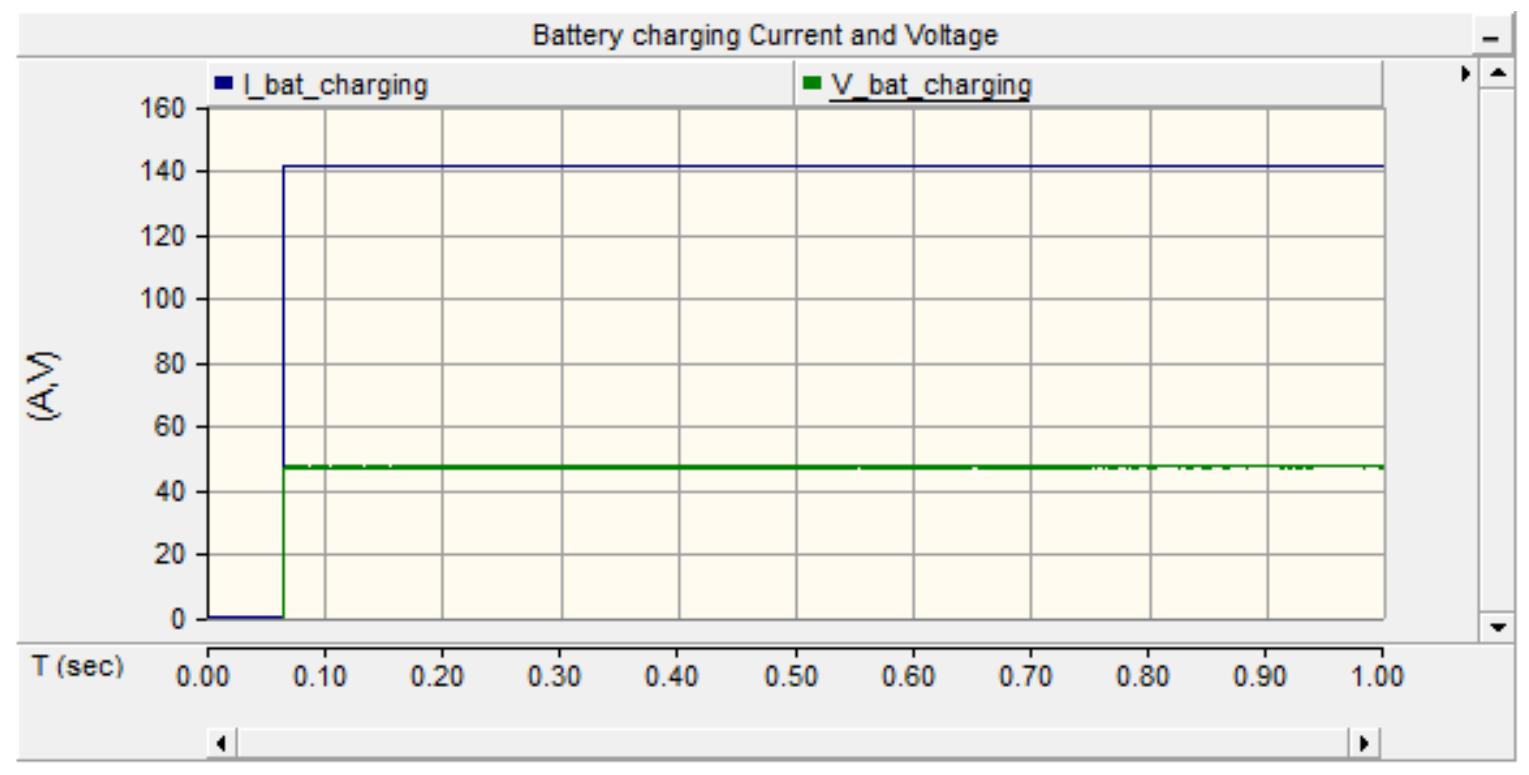

Figure 4-23: Battery Current (blue) and Voltage (green) 
Figure 4-24 illustrates the voltage stability in the network while the battery bank is charging. Figures 4-25 and 4-26 show the current and power in the network and verify that the operation of the distribution network is not compromised when the batteries are charging.

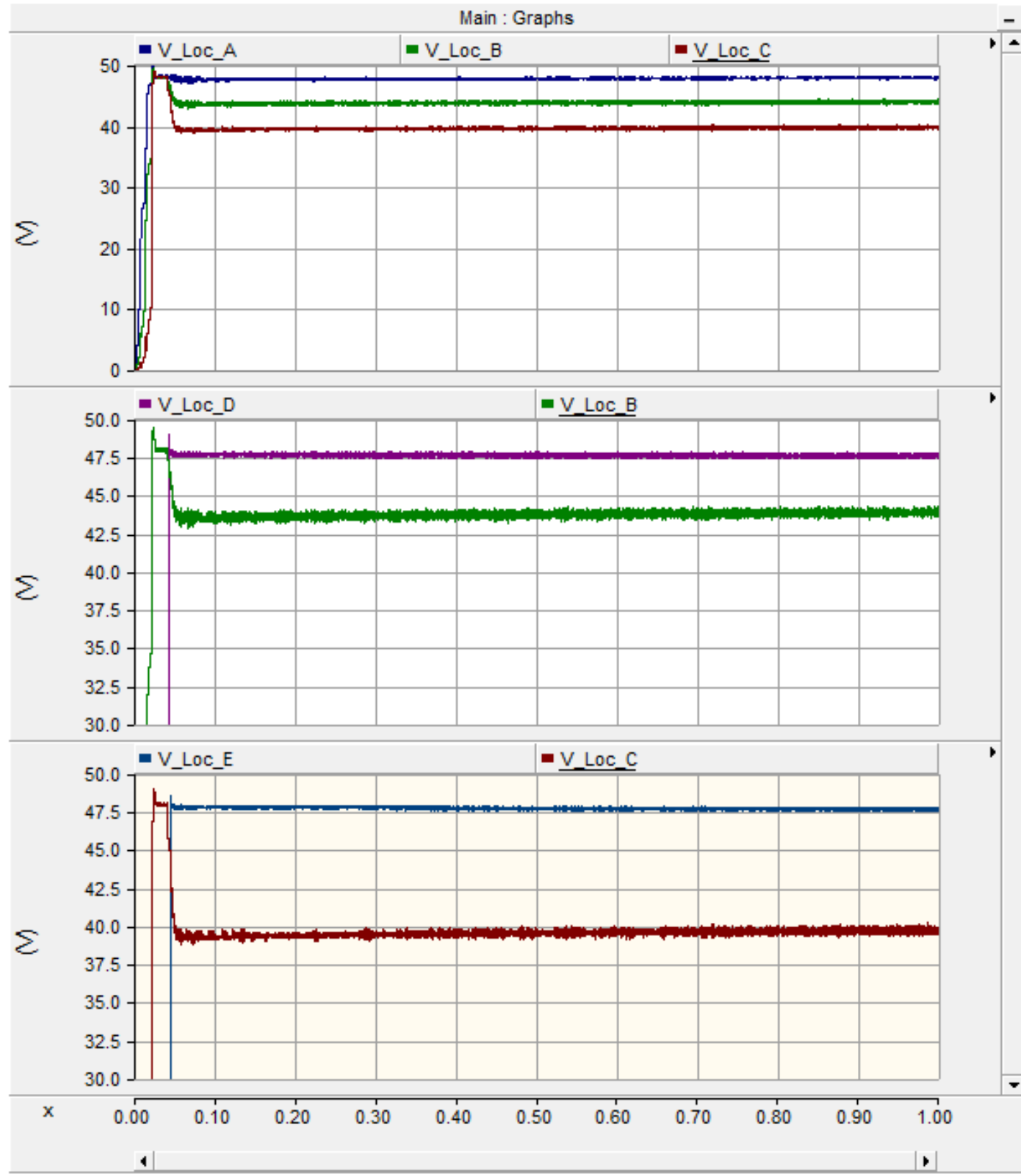

Figure 4-24: Voltage Measurements of the Distribution Network at Five Locations While the Battery Bank is being charged 


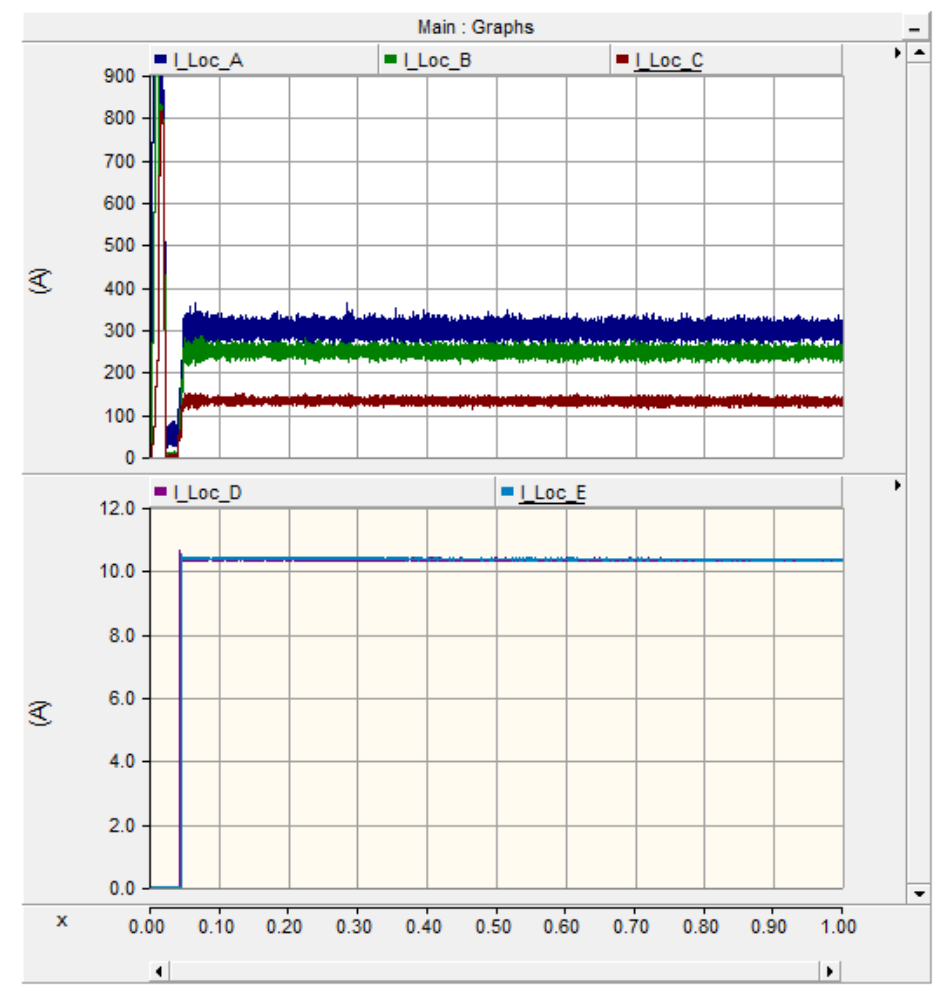

Figure 4-25: Current Measurements of the Distribution Network at Five Locations While the Battery Bank is being charged

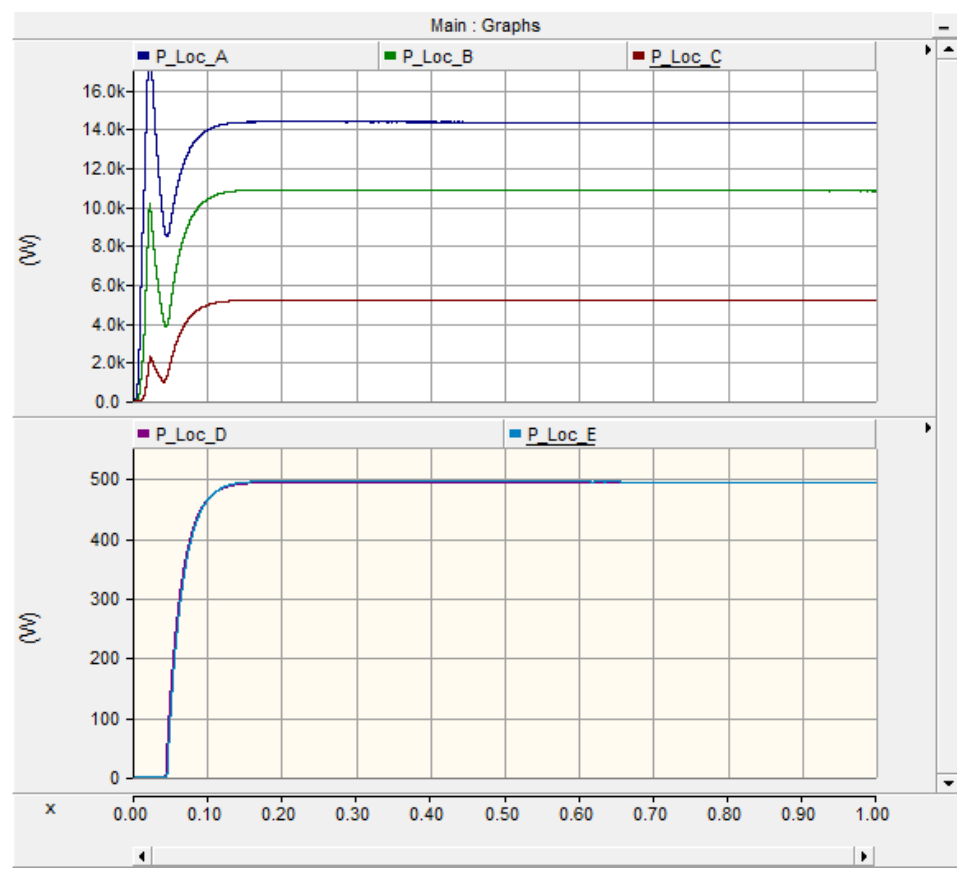

Figure 4-26: Power Measurements of the Distribution Network at Five Locations While the Battery Bank is being charged 


\section{5: Battery Bank Supplying the Load}

\subsection{1: Varying Load}

Similar to the test case in section 4.3.2, the load is varied from $100 \mathrm{~W}$ to $500 \mathrm{~W}$ with steps of 50W every 0.1 seconds; however, the load is supplied from the battery bank instead of PV (emulating night time or cloudy weather conditions). The input parameters of the battery bank are shown in Figure 3-38 (previous chapter). Figure 4-27 shows the voltage stability in the network as the load is increased. The DC bus voltage is regulated at $48 \mathrm{~V}$ by the Boost Converter, which is cascaded with the battery bank (Figure 4-1). The voltage for the DC Houses (Locations D and E) is observed at 48V. Figures 4-28 and 429 show the current and power flow in the network with the increasing load.

Furthermore, Figure 4-30 shows the decreasing SOC (state of charge) of the battery with time, which shows that power is being drawn from the battery. This test case verifies that the battery bank is able to provide smooth power to the DC Houses during nongeneration periods. 


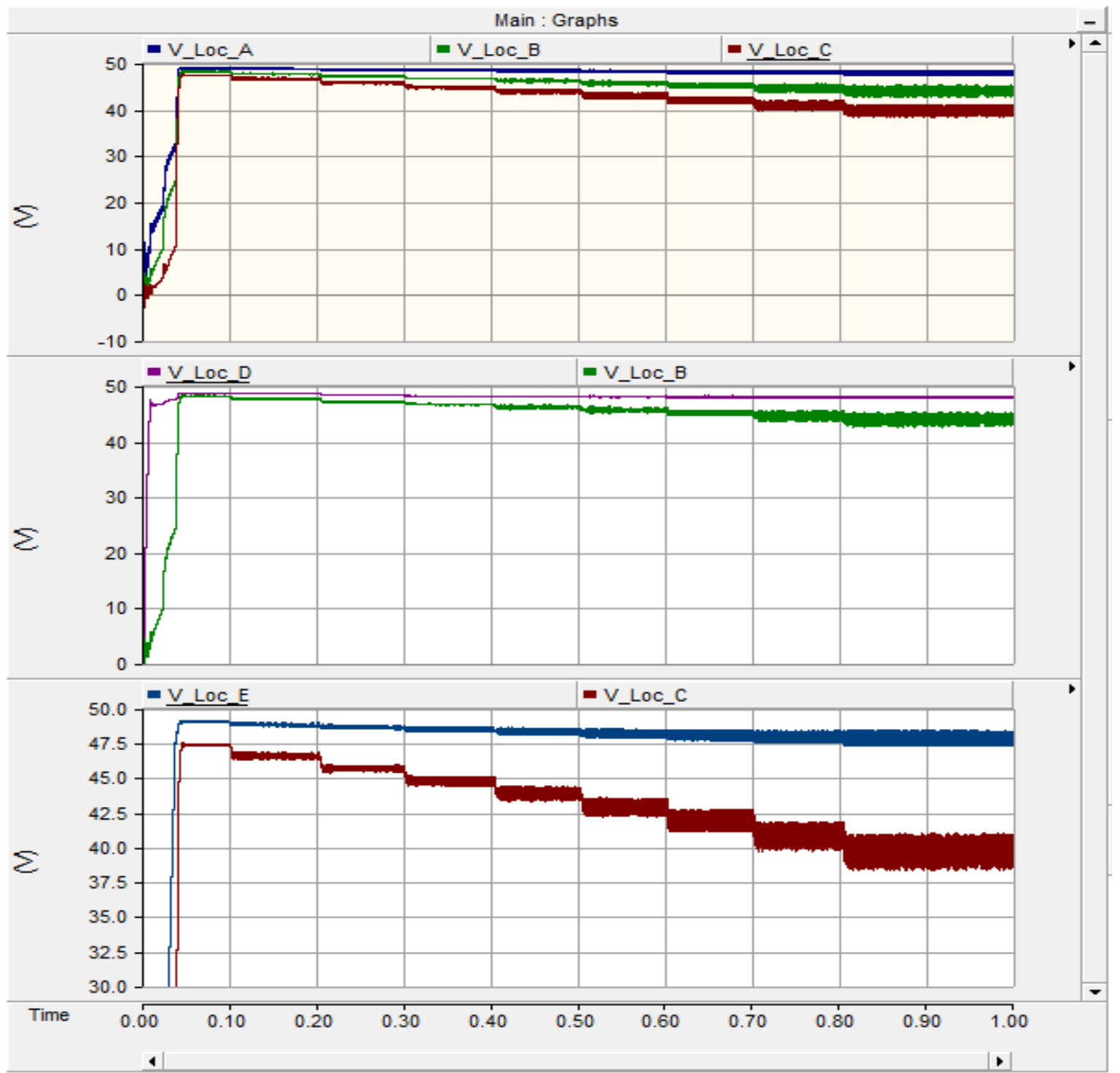

Figure 4-27: Voltage Measurements of Distribution Network at Five Locations as Load is increased from $100 \mathrm{~W}$ to $500 \mathrm{~W}$ in steps of $50 \mathrm{~W}$ (Powered from Battery) 


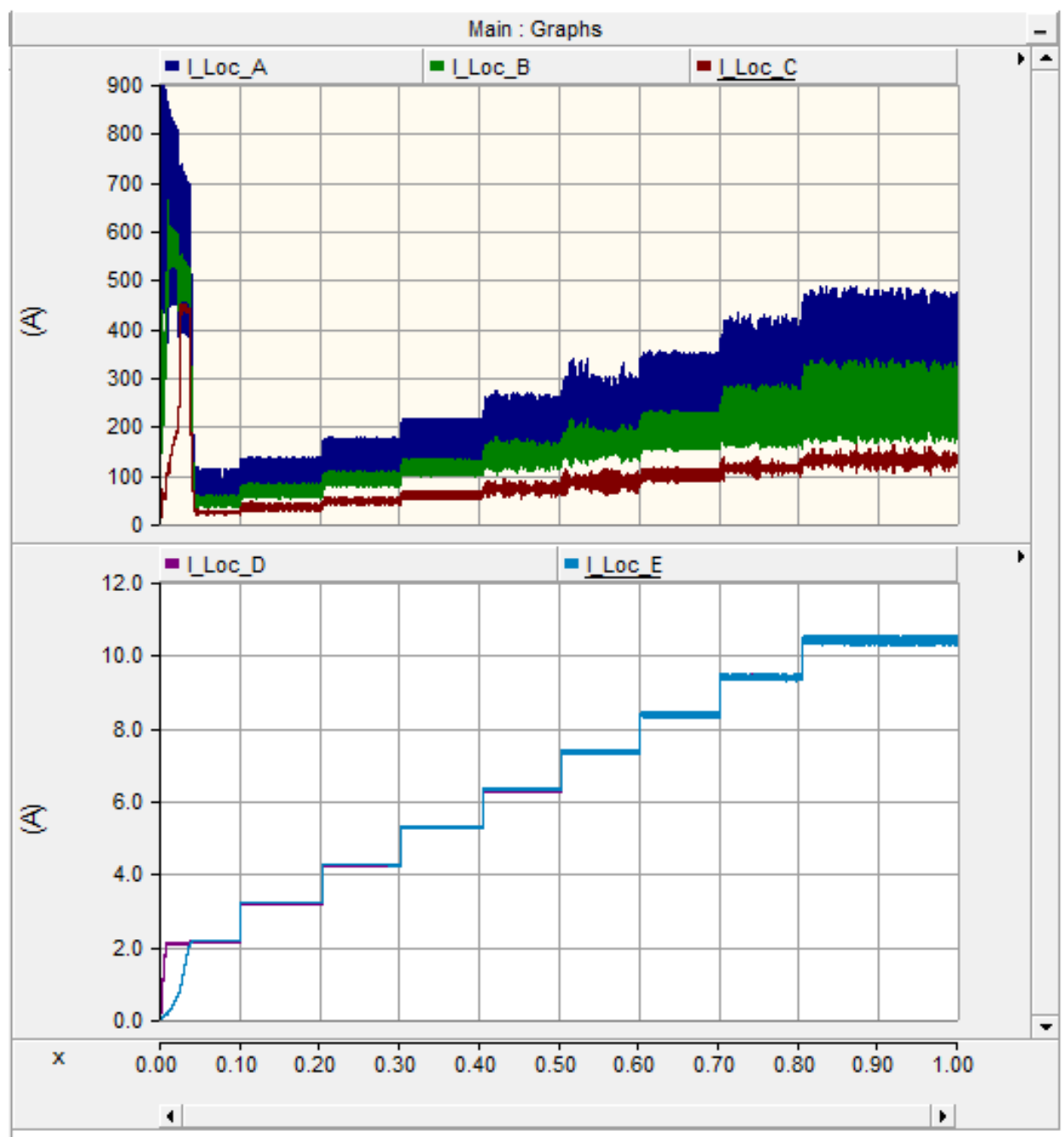

Figure 4-28: Current Measurements of Distribution Network at Five Locations as Load is increased from $100 \mathrm{~W}$ to $500 \mathrm{~W}$ in steps of 50W (Powered from Battery) 


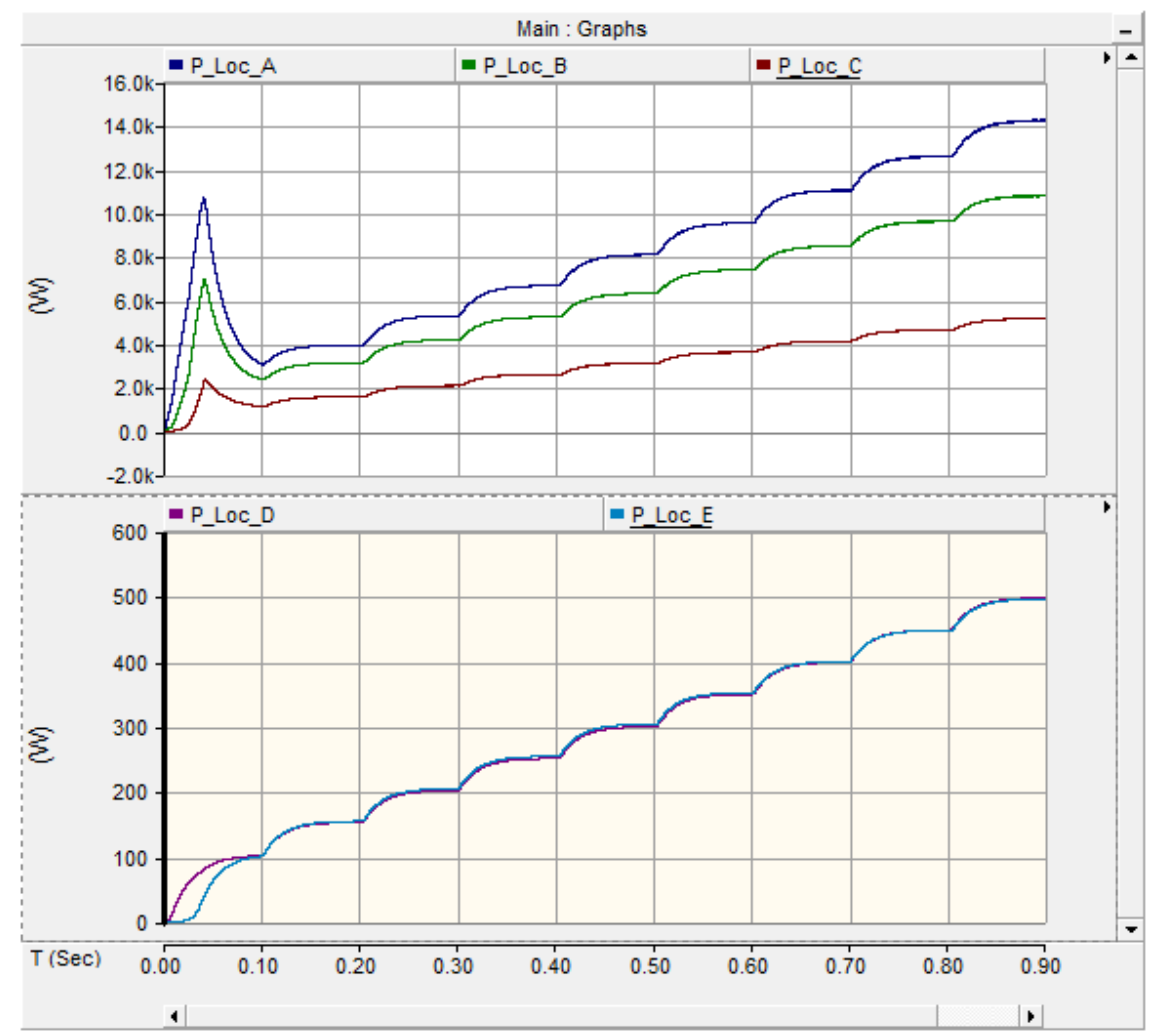

Figure 4-29: Power Measurements of Distribution Network at Five Locations as Load is increased from $100 \mathrm{~W}$ to $500 \mathrm{~W}$ in steps of 50W (Powered from Battery)

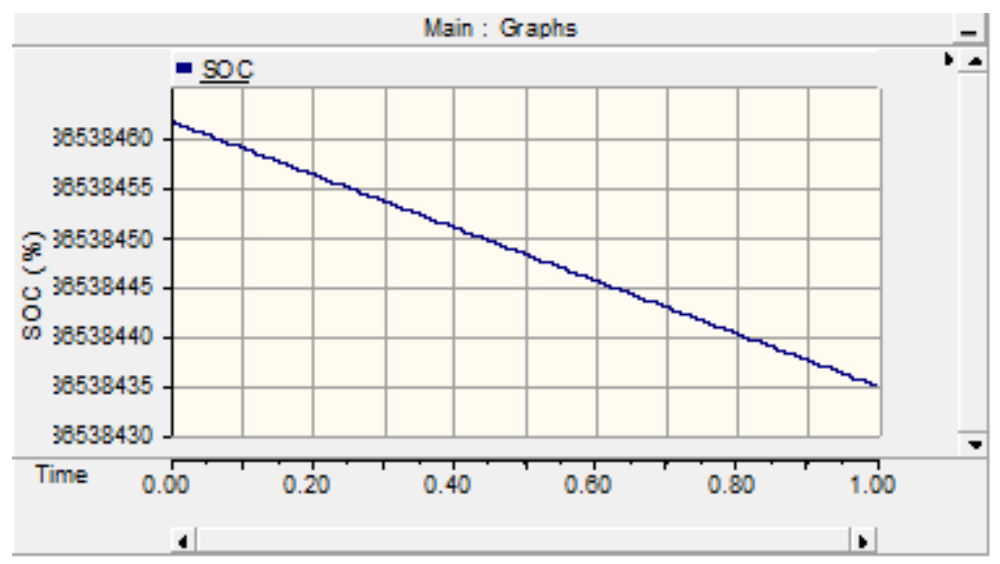

Figure 4-30: Battery Bank State of Charge (SOC) 


\subsection{2: Varying Number of Houses Operating}

In this test case, the number of houses consuming power is increased from 5 to 25 in steps of 4 every .2 seconds. Figure 4-31 shows voltage stability in the network as the number of houses consuming power is increased. As more houses starts consuming power, the voltage at locations B and C dropped. But Boost Converters keep the distributed house voltage at 48V (Locations D and E). Similarly Figures 4-32 and 4-33 show the current and power flow in the network. This test case verifies that the battery bank is able to provide smooth power as the number of houses consuming power increase.

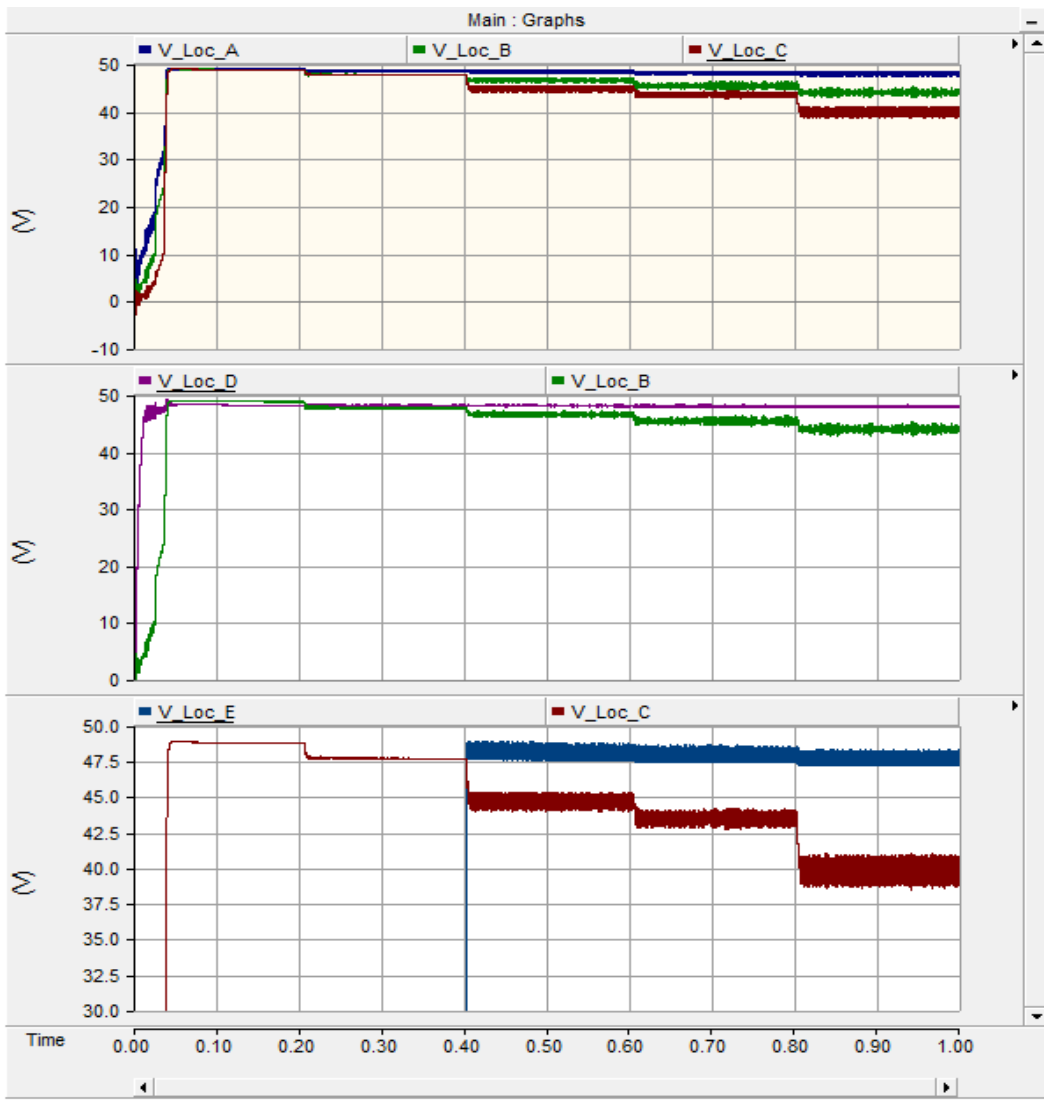

Figure 4-31: Voltage Measurements of Distribution Network at Five Locations as number of houses is incremented (Powered from Battery) 


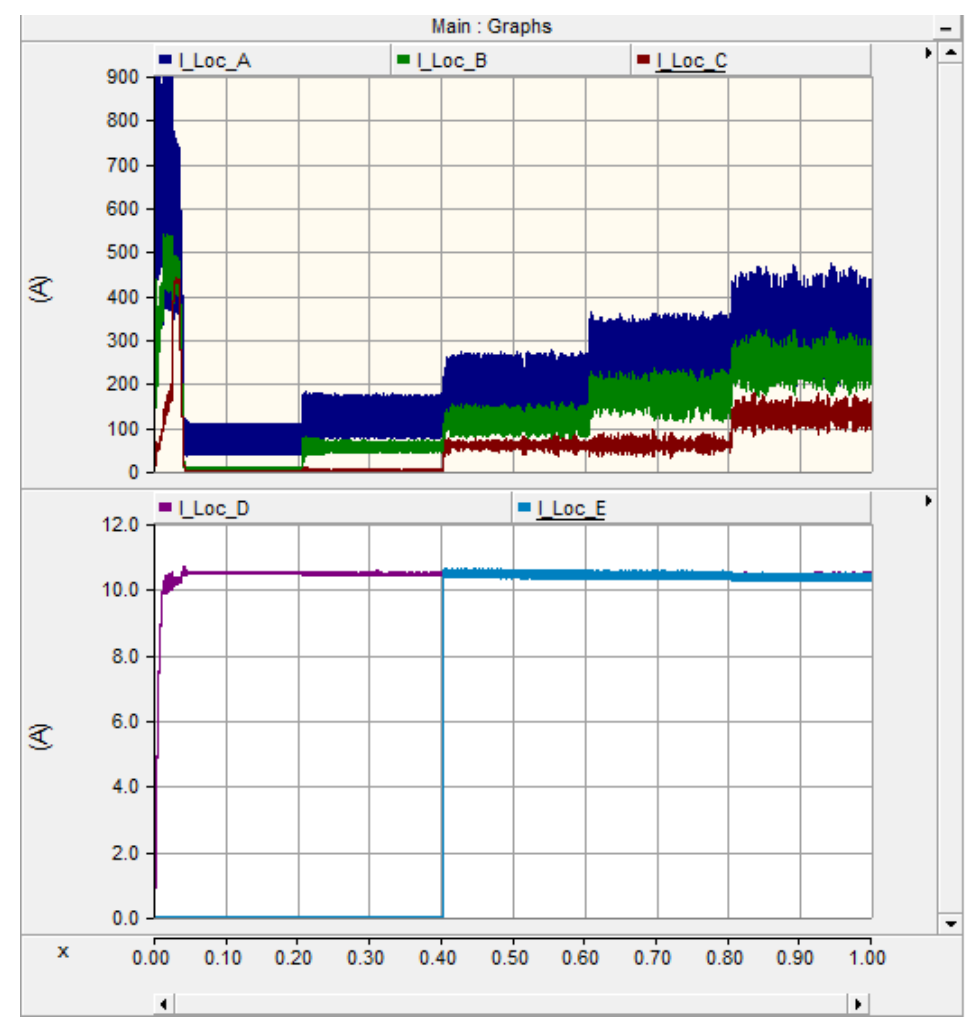

Figure 4-32: Current Measurements of Distribution Network at Five Locations as number of houses is incremented (Powered from Battery)

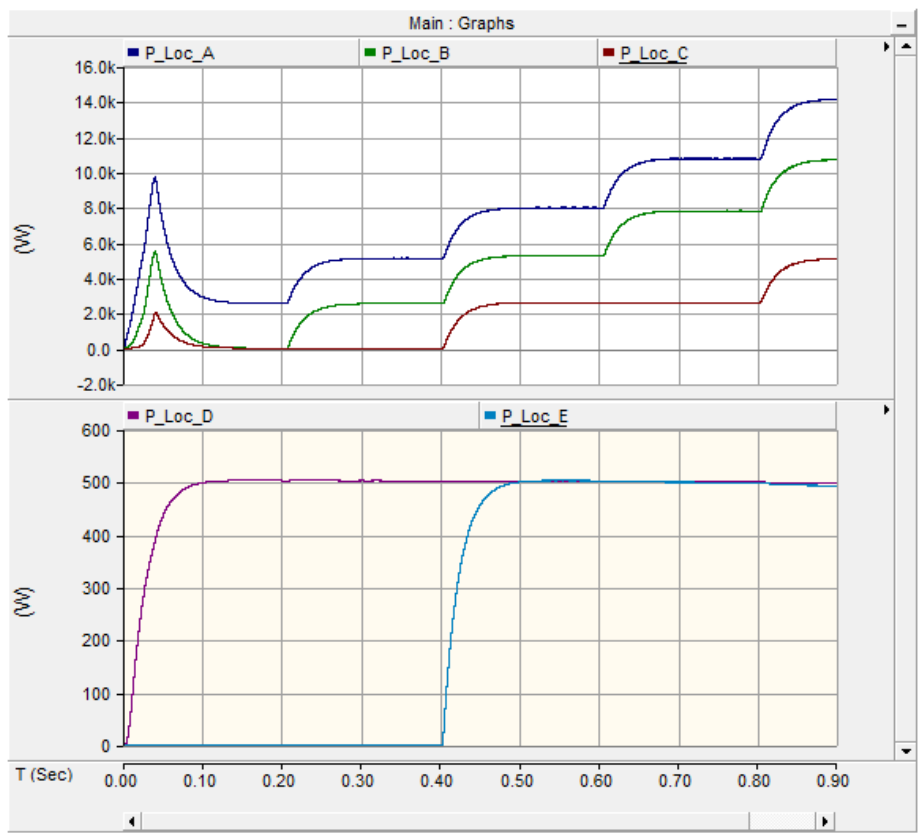

Figure 4-33: Power Measurements of Distribution Network at Five Locations as number of houses is incremented (Powered from Battery) 


\section{6: $\quad$ System Cost Analysis}

The major factor driving the growth of the renewable energy sources such as photovoltaic is their competitive cost, which has been decreasing for the past two decades. The DC distribution method is chosen for our system because it is more efficient and requires fewer components than an $\mathrm{AC}$ distribution method. In the following sections, a DC vs. AC distribution cost analysis is performed for a system that could range from $10 \mathrm{~kW}$ to $100 \mathrm{~kW}$.

\subsection{1: PV Array and MPPT Charge Controller Cost}

The adequate sizing of $\mathrm{PV}$ array is important to prolong the life of the system components, house appliances, and battery bank. PV array sizing is based on the lowest insolation month (critical month) of the place where system will be implemented. Since the DC house project is to be mainly used in developing countries, the insolation data of Jakarta, Indonesia, will provide for system sizing. From the data in Figure 4-34, it is clear that the lowest insolation month in Jakarta is January when the average insolation is 4.25 $\mathrm{kWh} / \mathrm{m}^{2} /$ day.

\begin{tabular}{|c|c|c|c|c|c|c|c|c|c|c|c|c|}
\hline Variable & $\mathbf{I}$ & II & III & IV & $\mathrm{V}$ & VI & vII & VIII & LX & $\mathrm{X}$ & XI & XII \\
\hline Insolation, $\mathbf{k W h} / \mathrm{m}^{2} / \mathrm{day}$ & 4.25 & 4.75 & 5.19 & 5.22 & 5.10 & 4.93 & 5.26 & 5.92 & 6.29 & 5.81 & 5.00 & 4.45 \\
\hline Clearness, $0-1$ & 0.40 & 0.45 & 0.50 & 0.53 & 0.56 & 0.57 & 0.60 & 0.63 & 0.62 & 0.55 & 0.47 & 0.43 \\
\hline Temperature, ${ }^{\circ} \mathrm{C}$ & 26.08 & 26.03 & 26.26 & 26.75 & 27.01 & 26.92 & 26.54 & 26.45 & 26.49 & 26.47 & 26.39 & 26.27 \\
\hline Wind speed, $\mathbf{m} / \mathbf{s}$ & 3.19 & 3.15 & 2.41 & 2.65 & 3.60 & 4.05 & 5.00 & 5.06 & 4.34 & 3.17 & 2.72 & 2.63 \\
\hline Precipitation, mm & 406 & 298 & 245 & 195 & 173 & 100 & 77 & 77 & 93 & 146 & 174 & 225 \\
\hline Wet days, d & 16.9 & 13.8 & 15.5 & 15.5 & 13.7 & 11.5 & 8.6 & 7.9 & 8.0 & 12.3 & 17.0 & 18.4 \\
\hline
\end{tabular}

Figure 4-34: Jakarta Indonesia Monthly Insolation [36] 
The total daily energy demand for the system is based on 4 hours at full load, 12 hours at $60 \%$ of the load and 8 hours at $30 \%$ of load (night). Total energy demand for a $10 \mathrm{~kW}$ system is calculated using:

$$
\begin{aligned}
\frac{\text { Energy demand }}{\text { day }} & =10 \mathrm{~kW} \times 4 h r s+6 \mathrm{~kW} \times 12 \mathrm{hrs}+3 \mathrm{~kW} \times 8 \mathrm{hrs} \\
& =136 \mathrm{kWh}
\end{aligned}
$$

These energy demand calculations take into consideration the energy required to charge the battery bank. Table 4-8 shows the PV array sizing and cost calculations based on $85 \%$ system efficiency.

\begin{tabular}{|c|c|}
\hline \multicolumn{2}{|l|}{ PV Sizing_Insolation_ $4.25 \mathrm{~W} / \mathrm{m}^{\wedge} 2$} \\
\hline & $10 \mathrm{kw}$ system \\
\hline & Max eff \\
\hline C1 Total energy demand per day $\left(\mathrm{C}^{*} 48\right)(\mathrm{W})$ & 136000.00 \\
\hline C2 System efficieny & 0.85 \\
\hline C3 Required array output per day (W) (C1/ C2) & 160000.0 \\
\hline C4 Selected PV module max power voltage at STC (x.85) & 36.08 \\
\hline C5 Selected PV module guaranteed power output at STC & 285 \\
\hline C6 Peek sum hours at design tilt for design month & 4.25 \\
\hline C7 Energy output per module per day ( $\mathrm{C} 5 \mathrm{xC} 6)$ & 1211.25 \\
\hline \multicolumn{2}{|l|}{ C8 Module energy output at operating temperature (DFxC7) } \\
\hline \multicolumn{2}{|l|}{ DF $=0.80$ for hot climates and critical applications. } \\
\hline DF $=0.90$ for moderate climates and non-critical applications. & 1090.125 \\
\hline \multirow{2}{*}{ C9 Number of modules required to meet energy requirements ( $\mathrm{C} 3 / \mathrm{C}$} & 146.77 \\
\hline & 147.00 \\
\hline C10 Number of modules required per string (A2 / C4) & 2 \\
\hline C11 Number of strings in parallel $(\mathrm{Cg} / \mathrm{C} 10)$ rounded & 74 \\
\hline C12 Number of modules to be purchased (C10 x C11) & 148 \\
\hline Invdividual Panel Price & 193.80 \\
\hline Total Cost & $\$ \quad 28,682.40$ \\
\hline
\end{tabular}

Table 4-8: PV Array Sizing and Cost Calculations 
JAP6- 285W solar module is selected for the system due to its competitive price per watt (Appendix A). Table 4-9 summarizes the cost for a system ranging from $10 \mathrm{~kW}$ to $100 \mathrm{~kW}$ with $85 \%$ and $75 \%$ system efficiencies. The data from the table are plotted in Figure 4-35. The plot shows that improving the system efficiency is significant in reducing the high initial cost for a PV system.

Table 4-9: Summary of PV Cost for $85 \%$ and $75 \%$ System Efficiency

\begin{tabular}{|c|rr|rr|}
\hline System kW & \multicolumn{2}{|c|}{$\mathbf{8 5 \%}$ eff } & \multicolumn{2}{c|}{$\mathbf{7 5 \%}$ eff } \\
\hline 10 & $\$ 28,682.40$ & $\$$ & $32,558.40$ \\
\hline 20 & $\$$ & $56,977.20$ & $\$$ & $64,729.20$ \\
\hline 30 & $\$$ & $85,659.60$ & $\$$ & $96,900.00$ \\
\hline 40 & $\$ 113,954.40$ & $\$$ & $129,070.80$ \\
\hline 50 & $\$ 142,249.20$ & $\$$ & $161,241.60$ \\
\hline 60 & $\$ 170,931.60$ & $\$$ & $193,800.00$ \\
\hline 70 & $\$ 199,226.40$ & $\$$ & $225,970.80$ \\
\hline 80 & $\$ 227,908.80$ & $\$$ & $258,141.60$ \\
\hline 90 & $\$ 256,203.60$ & $\$$ & $290,312.40$ \\
\hline 100 & $\$ 284,498.40$ & $\$$ & $322,483.20$ \\
\hline
\end{tabular}

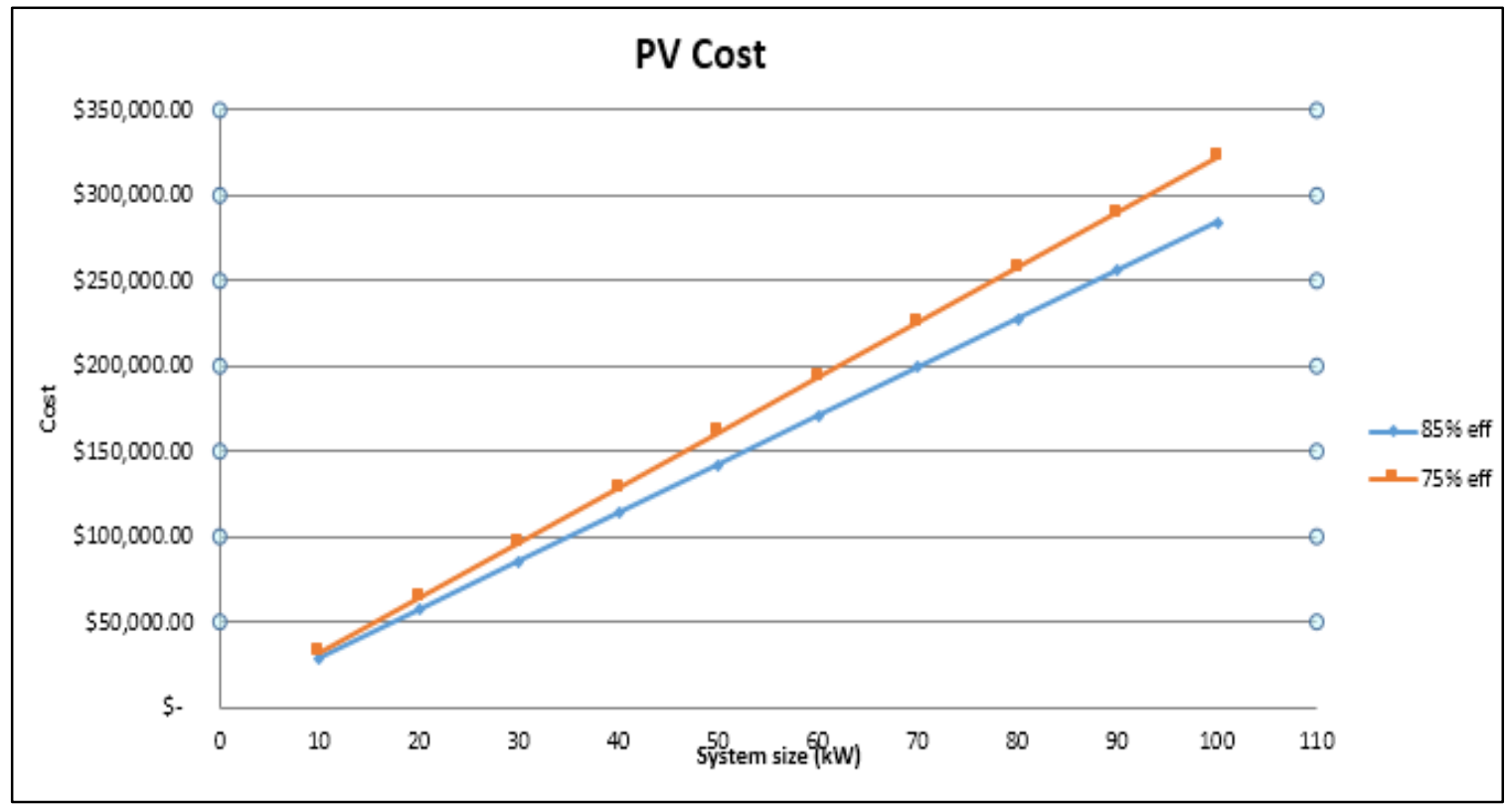


Figure 4-35: DC Distribution PV Cost with $85 \%$ and $75 \%$ Efficiency

The MPPT charge controller selected for the system is Outback FM-80 Flexmax (Appendix B). This charge controller takes the varying voltage from the PV array and produces a stable $48 \mathrm{~V}$ voltage for the DC bus. A Single FM- 80 controller has output power rating of $3840 \mathrm{~W}$ and costs $\$ 584$. Table 4-10 lists the number of controllers required and their corresponding costs.

Table 4-10: MPPT Charge Controller Cost

\begin{tabular}{|c|c|c|}
\hline System kW & $\begin{array}{c}\text { MPPT } \\
\text { controllers } \\
\text { required }\end{array}$ & $\begin{array}{c}\text { Total } \\
\text { Cost }\end{array}$ \\
\hline 10 & 3 & $\$ 1,752$ \\
\hline 20 & 6 & $\$ 3,504$ \\
\hline 30 & 8 & $\$ 4,672$ \\
\hline 40 & 11 & $\$ 6,424$ \\
\hline 50 & 14 & $\$ 8,176$ \\
\hline 60 & 16 & $\$ 9,344$ \\
\hline 70 & 19 & $\$ 11,096$ \\
\hline 80 & 21 & $\$ 12,264$ \\
\hline 90 & 24 & $\$ 14,016$ \\
\hline 100 & 27 & $\$ 15,768$ \\
\hline
\end{tabular}

\subsection{2: Battery Bank Cost}

The storage capacity required for the battery bank depends on the number of days batteries can provide power to the load without recharging. Depth of Discharge (DOD) is the amount of energy drawn from a battery compared to its total storage capacity. For a PV system, two common terms related to DOD are maximum DOD and average daily DOD. Maximum DOD is the maximum amount of charge that can be drawn out of the battery. It is also related to the autonomy capacity required to operate the system loads 
for given number of days with no generation from PV. A system designed with very low DOD will have most of the battery energy available to the load but with a trade-off for longer battery life. The average daily DOD is the amount of energy drawn from battery's full capacity with the average daily load profile. A system designed for longer autonomy periods (more capacity) will have lower average daily DOD. For this system, DOD of $80 \%$ is selected, which is typical for isolated PV storage systems. For the battery bank, Trojan T105-RE Flooded lead-acid battery is selected (Appendix C), which has 225A of capacity with $6 \mathrm{~V}$ terminal voltage. Table 4-11 shows the calculations for the number of batteries required for a $10 \mathrm{~kW}$ to $100 \mathrm{~kW}$ system and their corresponding costs, assuming two days of autonomy storage are required. 
Table 4-11: Battery Bank Sizing for 2 Days of Autonomy Storage

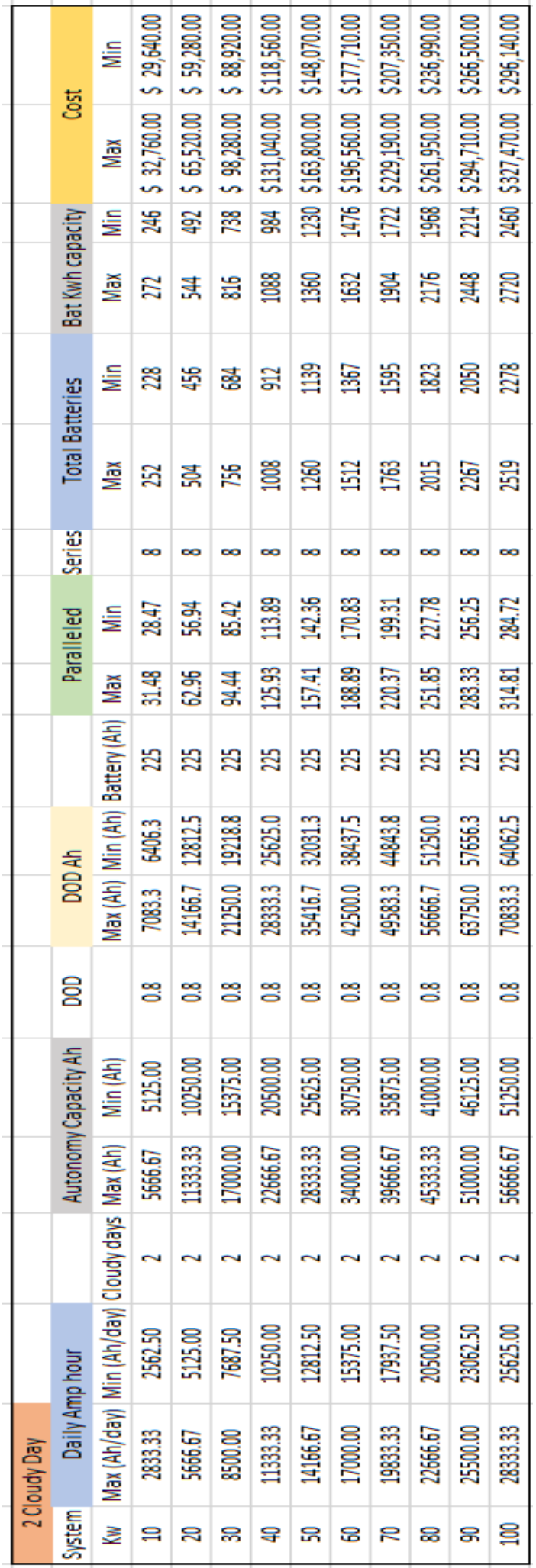


Furthermore, Table 4-12 summarizes the variations in the battery cost as the size of the system and number of days are varied. Data shows that the battery cost is significantly higher as the autonomy storage days are increased. This is because battery prices have not dropped like the PV module prices. Additionally Figure 4-36 shows a 3D graph of the battery cost.

Table 4-12: Battery Cost Varied with System Size and Storage Capacity

\begin{tabular}{|c|c|c|c|c|c|c|}
\hline \multirow{2}{*}{$\begin{array}{l}\text { System } \\
\text { Size (KW }\end{array}$} & \multicolumn{6}{|c|}{ Cloudy day storage } \\
\hline & \multicolumn{2}{|c|}{0 (14 hr night) } & 1 & 2 & 3 & 4 \\
\hline 10 & $\$$ & $5,850.00$ & $\$ 14,820.00$ & $\$ 29,640.00$ & $\$ 44,460.00$ & $\$ 59,280.00$ \\
\hline 20 & $\$$ & $11,570.00$ & $\$ 29,640.00$ & $\$ 59,280.00$ & $\$ 88,920.00$ & $\$ 118,560.00$ \\
\hline 30 & $\$$ & $17,420.00$ & $\$ 44,460.00$ & $\$ 88,920.00$ & $\$ 133,250.00$ & $\$ 177,710.00$ \\
\hline 40 & $\$$ & $23,140.00$ & $\$ 59,280.00$ & $\$ 118,560.00$ & $\$ 177,710.00$ & $\$ 236,990.00$ \\
\hline 50 & $\$$ & $28,990.00$ & $\$ 74,100.00$ & $\$ 148,070.00$ & $\$ 222,170.00$ & $\$ 296,140.00$ \\
\hline 60 & $\$$ & $34,710.00$ & $\$ 88,920.00$ & $\$ 177,710.00$ & $\$ 266,500.00$ & $\$ 355,420.00$ \\
\hline 70 & $\$$ & $40,560.00$ & $\$ 103,740.00$ & $\$ 207,350.00$ & $\$ 310,960.00$ & $\$ 414,570.00$ \\
\hline 80 & $\$$ & $46,280.00$ & $\$ 118,560.00$ & $\$ 236,990.00$ & $\$ 355,420.00$ & $\$ 473,850.00$ \\
\hline 90 & $\$$ & $52,000.00$ & $\$ 133,250.00$ & $\$ 266,500.00$ & $\$ 399,750.00$ & $\$ 533,000.00$ \\
\hline 100 & $\$$ & $57,850.00$ & $\$ 148,070.00$ & $\$ 296,140.00$ & $\$ 444,210.00$ & $\$ 592,280.00$ \\
\hline
\end{tabular}




\section{Battery Cost}

$\$ 600,000.00$

$\$ 500,000.00$

$\$ 400,000.00$

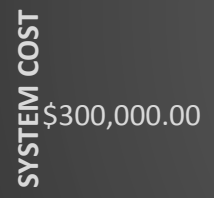

告

$\$ 200,000.00$

$\$ 100,000.00$

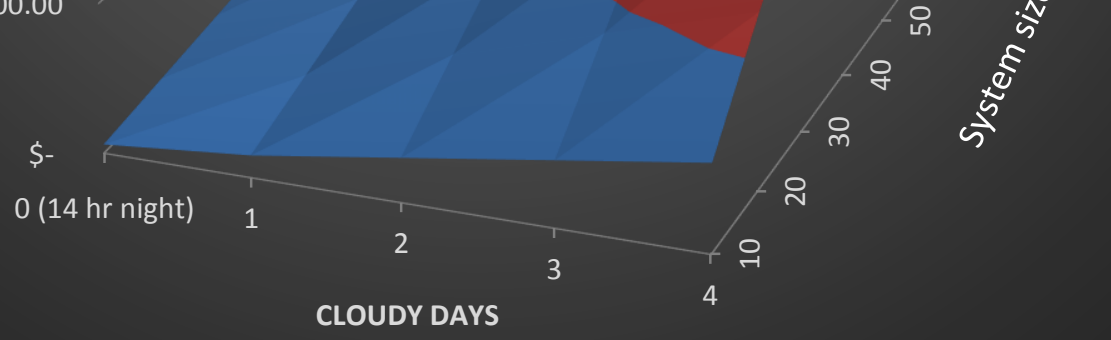

Figure 4-36: Battery Bank Cost with Increasing System Size and Storage Capacity 


\subsection{3: Distribution Cost}

The selection criteria for the distribution conductors is their DC resistance and prices. For the main distribution lines, ASCR Waxing (266.8 kcmil) conductor is chosen and Raven (1/0 AWG) is selected to connect single house to the main conductors. Table 4-13 shows the calculated cost for the $10 \mathrm{~kW}$. Table 4-14 shows the total distribution cost for the wiring and Boost Converter (Appendix D) for a $10 \mathrm{kw}-100 \mathrm{~kW}$ system.

Table 4-13: Distribution Wiring Cost for a $10 \mathrm{~kW}$ System.

\begin{tabular}{|l|l|r|r|r|}
\hline $10 \mathrm{KW}$ Wiring Min Cost & & & \\
& & & & \\
Waxwing & $1 \times 266.8$ & 1.35 & 842.45 & $\$ 1,137.31$ \\
\hline Raven & $1 / 0$. AWG & 1.625 & 370.52 & $\$ 602.10$ \\
\hline & & & Total & $\$ 1,739.40$ \\
\hline
\end{tabular}

Table 4-14: Distribution Wiring and Boost Converter Cost

\begin{tabular}{|c|cc|r|}
\hline \multicolumn{4}{|c|}{ Distribution Cost } \\
\hline $\begin{array}{c}\text { System } \\
\text { Size (KW) }\end{array}$ & $\begin{array}{c}\text { Wiring } \\
\text { Cost }\end{array}$ & $\begin{array}{c}\text { Boost Coverter } \\
\text { Cost }\end{array}$ \\
\hline 10 & $\$$ & $1,739.40$ & $\$ 1,400$ \\
20 & $\$$ & $3,478.81$ & $\$ 2,800$ \\
\hline 30 & $\$$ & $5,218.21$ & $\$ 4,200$ \\
40 & $\$$ & $6,957.61$ & $\$ 5,600$ \\
\hline 50 & $\$$ & $8,697.01$ & $\$ 7,000$ \\
60 & $\$$ & $10,436.42$ & $\$ 8,400$ \\
\hline 70 & $\$$ & $12,175.82$ & $\$ 9,800$ \\
\hline 80 & $\$$ & $13,915.22$ & $\$ 11,200$ \\
\hline 90 & $\$$ & $15,654.62$ & $\$ 12,600$ \\
100 & $\$$ & $17,394.03$ & $\$ 14,000$ \\
\hline
\end{tabular}

Table 4-15 shows the total cost of the Centralized DC Distribution System for the DC House. The battery cost is for the best case scenario, which is only accounting for 
enough storage for the night-time operations. This cost will multiply if more autonomy storage capacity is desired.

Table 4-15: Total DC System Cost

\begin{tabular}{|c|c|c|c|c|c|c|}
\hline \multirow{2}{*}{$\begin{array}{c}\text { System } \\
\text { kW }\end{array}$} & \multirow{2}{*}{$\begin{array}{c}\text { PV } \\
\text { Cost }\end{array}$} & \multirow{2}{*}{$\begin{array}{c}\text { MPPT } \\
\text { Cost }\end{array}$} & \multirow{2}{*}{$\begin{array}{c}\text { Battery } \\
\text { Cost }\end{array}$} & \multicolumn{2}{|c|}{ Distribution } & \multirow[t]{2}{*}{ Total DC cost } \\
\hline & & & & Wiring & Boost & \\
\hline 10 & $\$ 28,682.40$ & $\$ 1,752$ & $\$ 5,850.00$ & $\$ 1,739.40$ & $\$ 1,400$ & $\$ 39,423.80$ \\
\hline 20 & $\$ 56,977.20$ & $\$ 3,504$ & $\$ 11,570.00$ & $\$ 3,478.81$ & $\$ 2,800$ & $\$ 78,330.01$ \\
\hline 30 & $\$ 85,659.60$ & $\$ 4,672$ & $\$ 17,420.00$ & $\$ 5,218.21$ & $\$ 4,200$ & $\$ 117,169.81$ \\
\hline 40 & $\$ 113,954.40$ & $\$ 6,424$ & $\$ 23,140.00$ & $\$ 6,957.61$ & $\$ 5,600$ & $\$ 156,076.01$ \\
\hline 50 & $\$ 142,249.20$ & $\$ 8,176$ & $\$ 28,990.00$ & $\$ 8,697.01$ & $\$ 7,000$ & $\$ 195,112.21$ \\
\hline 60 & $\$ 170,931.60$ & $\$ 9,344$ & $\$ 34,710.00$ & $\$ 10,436.42$ & $\$ 8,400$ & $\$ 233,822.02$ \\
\hline 70 & $\$ 199,226.40$ & $\$ 11,096$ & $\$ 40,560.00$ & $\$ 12,175.82$ & $\$ 9,800$ & $\$ 272,858.22$ \\
\hline 80 & $\$ 227,908.80$ & $\$ 12,264$ & $\$ 46,280.00$ & $\$ 13,915.22$ & $\$ 11,200$ & $\$ 311,568.02$ \\
\hline 90 & $\$ 256,203.60$ & $\$ 14,016$ & $\$ 52,000.00$ & $\$ 15,654.62$ & $\$ 12,600$ & $\$ 350,474.22$ \\
\hline 100 & $\$ 284,498.40$ & $\$ 15,768$ & $\$ 57,850.00$ & $\$ 17,394.03$ & $\$ 14,000$ & $\$ 389,510.43$ \\
\hline
\end{tabular}

\subsection{4: AC System Cost}

In order to justify the DC distribution method a comparison study was prepared for the AC distribution cost. The AC system is less efficient because of the extra conversion stages, which are not required in the DC distribution. The AC system requires an inverter to convert DC to AC on the source side. SMA Sunny Boy 10000TLUS-10 10 $\mathrm{kW}$ inverter is selected (Appendix E). The common AC distribution voltage is $12.4 \mathrm{kV}$, which means transformers are required to step-up the voltage at the source end and stepdown on the house side to supply the house at $120 \mathrm{~V}$. The transformer selected for the AC network is ABB Single phase overhead distribution transformer (Appendix F). Table 416 details the cost analysis for the AC system. The PV cost for the AC system is calculated assuming system efficiency of $75 \%$. The cost for MPPT charge controller and 
battery bank remains unchanged from the DC system. But the wiring cost is half of the DC system because smaller cable conductors are needed for the high voltage distribution.

Table 4-16: Total AC System Cost

\begin{tabular}{|c|c|c|c|c|c|c|c|c|c|c|}
\hline \multirow{2}{*}{$\begin{array}{c}\text { System } \\
\text { kw }\end{array}$} & \multirow{2}{*}{$\begin{array}{l}\text { PV } \\
\text { Cost }\end{array}$} & \multirow{2}{*}{$\begin{array}{l}\text { MPPT } \\
\text { Cost }\end{array}$} & \multirow{2}{*}{\multicolumn{2}{|c|}{$\begin{array}{c}\text { Battery } \\
\text { Cost }\end{array}$}} & \multirow{2}{*}{$\begin{array}{c}\text { Inverter } \\
\text { Cost }\end{array}$} & \multirow{2}{*}{$\begin{array}{c}\text { Transformer } \\
\text { Cost }\end{array}$} & \multicolumn{3}{|c|}{ Distribution } & \multirow{2}{*}{$\begin{array}{c}\text { Total AC } \\
\text { Cost }\end{array}$} \\
\hline & & & & & & & & Wiring & Transformer & \\
\hline 10 & $\$ 32,364.60$ & $\$ 1,752$ & $\$$ & $5,850.00$ & $\$ 3,305$ & $\$ 3,500$ & $\$$ & 869.70 & $\$ 5,000$ & $\$ 52,641.30$ \\
\hline 20 & $\$ 64,535.40$ & $\$ 3,504$ & $\$$ & $11,570.00$ & $\$ 6,610$ & $\$ 5,250$ & $\$$ & $1,739.40$ & $\$ 7,500$ & $\$ 100,708.80$ \\
\hline 30 & $\$ 96,900.00$ & $\$ 4,672$ & $\$$ & $17,420.00$ & $\$ 9,915$ & $\$ 7,000$ & $\$$ & $2,609.10$ & $\$ 10,000$ & $\$ 148,516.10$ \\
\hline 40 & $\$ 129,070.80$ & $\$ 6,424$ & $\$$ & $23,140.00$ & $\$ 13,220$ & $\$ 8,750$ & $\$$ & $3,478.81$ & $\$ 12,500$ & $\$ 196,583.61$ \\
\hline 50 & $\$ 161,241.60$ & $\$ 8,176$ & $\$$ & $28,990.00$ & $\$ 16,525$ & $\$ 10,500$ & $\$$ & $4,348.51$ & $\$ 15,000$ & $\$ 244,781.11$ \\
\hline 60 & $\$ 193,606.20$ & $\$ 9,344$ & $\$$ & $34,710.00$ & $\$ 19,830$ & $\$ 12,250$ & $\$$ & $5,218.21$ & $\$ 17,500$ & $\$ 292,458.41$ \\
\hline 70 & $\$ 225,777.00$ & $\$ 11,096$ & $\$$ & $40,560.00$ & $\$ 23,135$ & $\$ 14,000$ & $\$$ & $6,087.91$ & $\$ 20,000$ & $\$ 340,655.91$ \\
\hline 80 & $\$ 257,947.80$ & $\$ 12,264$ & $\$$ & $46,280.00$ & $\$ 26,440$ & $\$ 15,750$ & $\$$ & $6,957.61$ & $\$ 22,500$ & $\$ 388,139.41$ \\
\hline 90 & $\$ 290,312.40$ & $\$ 14,016$ & $\$$ & $52,000.00$ & $\$ 29,745$ & $\$ 17,500$ & $\$$ & $7,827.31$ & $\$ 25,000$ & $\$ 436,400.71$ \\
\hline 100 & $\$ 322,483.20$ & $\$ 15,768$ & $\$$ & $57,850.00$ & $\$ 33,050$ & $\$ 19,250$ & $\$$ & $8,697.01$ & $\$ 27,500$ & $\$ 484,598.21$ \\
\hline
\end{tabular}

Figure 4-36 graphs the cost difference between the DC and AC distributions. In this figure, the DC system is assumed to be at $85 \%$ efficiency and AC system to be at $75 \%$ efficiency. The cost difference between the two distribution methods grows larger as their efficiency gap increases. 


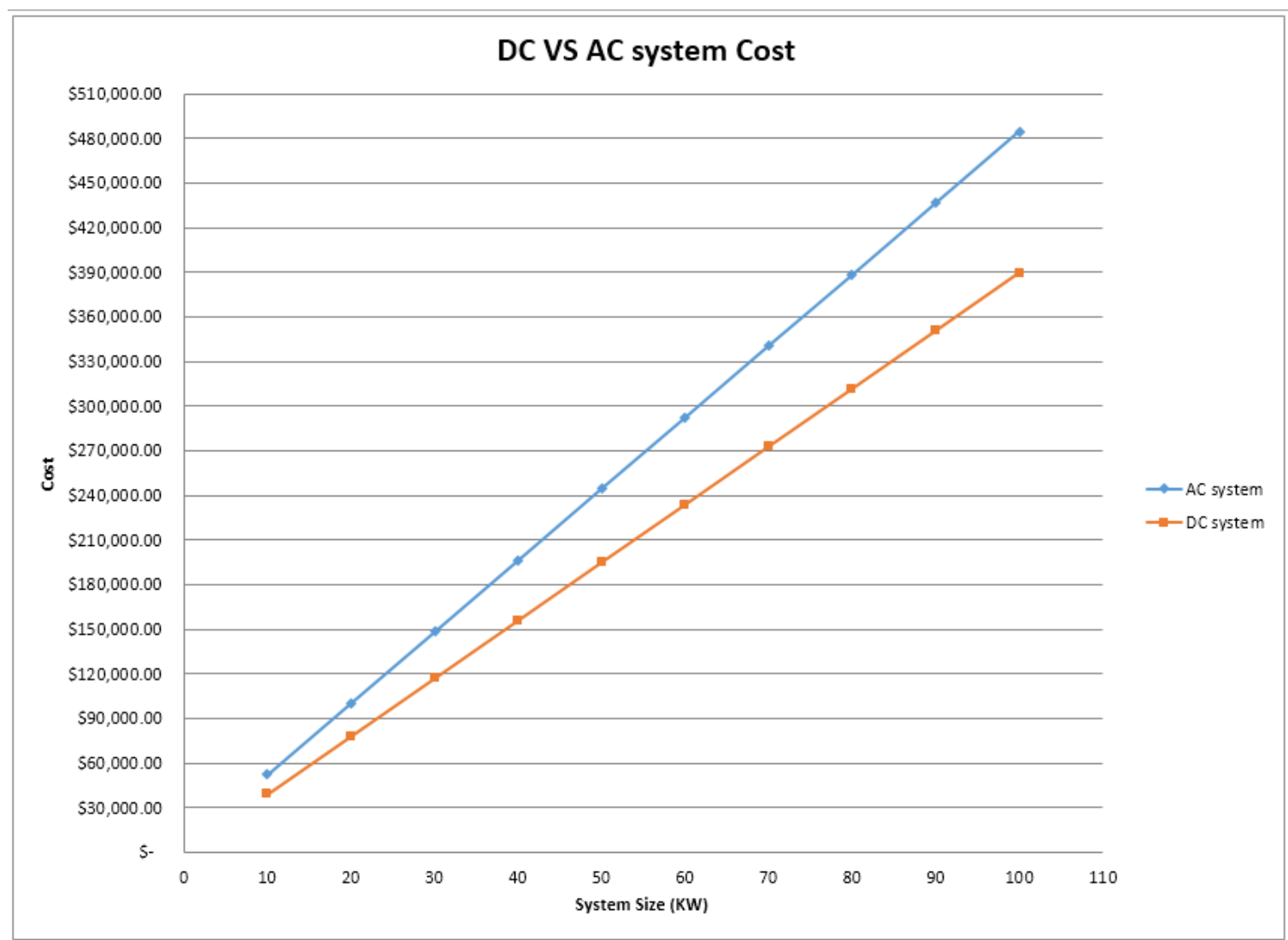

Figure 4-37: DC System Cost at 85\% Efficiency and AC System 75\% Efficiency 


\section{Chapter 5}

\section{Conclusion and Future Work}

\section{1: $\quad$ Summary and Conclusion}

This thesis focuses on the design, modeling, simulation, and performance evaluation of a DC House centralized distribution network. The complete system was modeled in PSCAD. The simulation results proved that the design meets the DC bus voltage stability requirements under different operating conditions. Different variations in the weather patterns can affect the PV generation. Simulation results further verified that the MPPT controller responds to the different weather patterns accordingly. The PV source is kept at its maximum power generating point by the MPPT controller and the buck converter by regulating the DC bus voltage at $48 \mathrm{~V}$. The PV source is able to supply the load and charge the battery bank during the peak sun hours without having any voltage instability at the DC bus. In addition, during night-time operation the battery bank is able to supply the load at stable $48 \mathrm{~V}$.

The distribution network layout was modeled with 25 houses (Figure 4-11). The voltage drops in the network were caused by the resistive losses of the conductors (Figure 4-12). The boost converters in the distribution network kept the voltage supplied to the load at 48V (Figure 4-12). 
The efficiency of the power converters at the source side was observed to range from $88.85 \%$ to $93.47 \%$, based on the load demand (Table 4-6). On the other hand, the efficiency of the distribution network depends on the distance that the network has to cover and the conductor type utilized. The losses in the distribution network can be minimized by choosing higher gauge conductors and reducing the distance if possible.

DC vs. AC cost analysis showed that the isolated DC centralized distribution system is more cost effective of the two systems. The AC distribution is burdened by the extra conversion stages which require extra components and reduce efficiency. Other factors, such as power factor correction and frequency stability, are not relevant in the DC system. The factors together provide for a simple, efficient and cost effective system.

\section{2: $\quad$ Future Work}

For simplicity, this study only included PV renewable source as part of the system but the concept of the DC House includes many other renewable sources such as: wind, hydro, human-powered generator. In the future work these sources can also be integrated into a larger simulation model.

More thorough study can also be performed on the performance of the battery bank by looking at the charge, discharge cycle and the battery health over its life. A battery bank is a heart of isolated this isolated distribution system therefore more thorough study will help improve the performance of the whole system.

This system is at a low voltage distribution which leads to high currents in the network. To ensure reliable operation of the distribution network, it is important to have a 
good protection system. Future simulations could create a protection scheme for the system by integrating current interruption devices in case of faults, relays and proper grounding schemes. Future study should also be conducted to determine the most optimum distribution voltage for the DC house network.

Overall this thesis produced a basic simulation model for the centralized DC house distribution system which will be further built upon in the future. 


\section{References}

[1] International Energy Agency, "CO2 Emissions From Fuel Combustion Highlights," IEA, Paris, 2012 .

[2] McaCarley, Art “ The Carbon Cycle and Global Warming.” Cal Poly San Luis Obispo University. EE 563 Seminar. 15 March 2013

[3] Novus Light Technologies Today, "EPIC Release Photovoltaic Industry Report," 2012. [Online]. Available: http://www.novuslight.com/epic-releasesphotovoltaic-industry-report_N182.html. [Accessed 2013].

[4] K. Liang, "Design of DC Light Bulb for teh DC House Project," California Polytechnic State University, San Luis Obispo, 2012.

[5] J. Kuderna, "RV Basics: 12-Volt DC Systems," RVtravel, [Online]. Available: http://www.rvtravel.com/publish/12-Volt_DC_Systems.shtml. [Accessed 2013].

[6] All About Circuits, "Skin Effect," [Online]. Available: http://www.allaboutcircuits.com/vol_2/chpt_3/6.html. [Accessed 2013].

[7] J. Parmar, "What is Corona Effect," 23 March 2011. [Online]. Available: http://electricalnotes.wordpress.com/2011/03/23/what-is-corona-effect/.

[8] J. Chaidez, "DC House Modeling and System Design," California Polytechnic State University, San Luis Obispo, 2011.

[9] Crowfoot, J., "Design and Modeling of the Cal Poly DC House Power Distribution System," California Polytechnic State University,, San Luis Obispo, 2011.

[10] Pratt, A.; Kumar, P.; Aldridge, T.V., "Evaluation of 400V DC distribution in telco and data centers to improve energy efficiency," Telecommunications Energy Conference, 2007. INTELEC 2007. 29th International

[11] Gab-Su Seo; Jongbok Baek; Kyusik Choi; Hyunsu Bae; Bohyung Cho, "Modeling and analysis of DC distribution systems," Power Electronics and ECCE Asia (ICPE \& ECCE), 2011 IEEE 8th International Conference 
[12] Lim, E.; Liu, S., "Wind Power Generator Design for the DC House Project," California Polytechnic State Univeristy, San Luis Obispo, 2011.

[13] Kwan, D.; Krug, M., "Hydro-Electric Generation System for the DC House Project," California Polytechnic State University, San Luis Obispo, 2011.

[14] Hayes, B.; Goguely, L., "Bicycle Power Generation Design for DC house: Off Grid Energy Solutions," California Polytechnic State UNiversity, San Luis Obispo, 2011.

[15] Tonkoski, R.; Turcotte, D.; EL-Fouly, T. H M, "Impact of High PV Penetration on Voltage Profiles in Residential Neighborhoods," Sustainable Energy, IEEE Transactions

[16] C. K. T. Wong, "A Multiple-Input Single-Output DC-DC Converter for the DC House Project," California Polytechnic State University, San Luis Obispo, 2011.

[17] O. Jong, "Multiple Input Single Output (MISO) DC-DC Converter For the DC House Project," California Polytechnic State University, San Luis Obispo, 2012.

[18] A. Ma, "Modling and Analysis Of a Photovoltaic System with a Distributed Energy Storage System," California Polytechnic State University,, San Luis Obispo, 2012.

[19] S. Jiang, "Battery Component in PSCAD/EMTDC," Manitoba HVDC Research Centre, Winnipeg, 2012.

[20] Taufik, "The DC House Project Promoting Sustainable Innovations in Renewable Energy Technology," California Polytechnic State University, San Luis Obispo.

[21] Rajapakse, A.D.; Muthumuni, D., "Simulation tools for photovoltaic system grid integration studies," Electrical Power \& Energy Conference (EPEC), 2009 IEEE

[22] P. Mars, "Using a Small Solar Cell and a Supercapacitor in a Wireless Sensor," Sensors, 1 July 2010. [Online]. Available: http://www.sensorsmag.com/networking-communications/energyharvesting/using-a-small-solar-cell-and-a-supercapacitor-a-wireless-sen-7310. [Accessed 2013].

[23] J. Dunlop, "Batteries and Charge Charge Control in Stand-Alone Photovoltaic Systems Fundamental and Application," Florida Solar Energy Center, 1997.

[24] Battery University, "Comparison Table of Secondary Batteries," [Online]. Available: 
http://batteryuniversity.com/index.php/learn/article/secondary_batteries. [Accessed 2013].

[25] E. Jones, "Lead Acid Batteries in Critical Applications Flooded vs. VRLA," C\&D Technologies, Inc,.

[26] Hund, T, Dunlop, J. and Farhi, B., "Test Results from the PV Battery Cycle-Life Test Procedure," Photovoltaic System Applications Department Sandia National Laboratories, Albuquerque, NM.

[27] Wholesale Solar, "Battery Bank Sizing Worksheet," [Online]. Available: http://www.wholesalesolar.com/battery_sizing.html. [Accessed 2013].

[28] Kadri,R; Andrei, H.; Gaubert, J.; Ivanovici,T.:, "Modeling of the photovoltaic cell circuit parameters for optimum connection model and real-time emulator with partial shadow conditions," Elsevier, 2011.

[29] Veerachary, M., "Maximum power point tracking parameter selection for higher order converters used in photovoltaic applications," Power Systems, 2009. ICPS '09. International Conference

[30] Esram, T.; Chapman, P.L., "Comparison of Photovoltaic Array Maximum Power Point Tracking Techniques," Energy Conversion, IEEE Transactions

[31] L. Guo, "PSCAD Simulation in a Power Electronics Application Course," Department of Technology Northern Illinois University, 2008.

[32] Taufik, "Introduction to Power Electronics", Notes, San Luis Obispo, 2011.

[33] Wikipedia, "Boost Converter," [Online]. Available: http://en.wikipedia.org/wiki/Boost_converter. [Accessed 2013].

[34] N. Rumzi, "Buck Converter," University Teknologi Malaysia (UTM), [Online]. Available: http://encon.fke.utm.my/nikd/SEM4413/AnalysisConverter-buck.pdf. [Accessed 2013].

[35] Coelho, R. F; Martins, D. C, "An Optimized Maximum Power Point Tracking Method Based on PV Surface Temperature Measurement," Federal University of Santa Catarina, Flrianopolis, Brazil.

[36] NASA, "Jakarta, Indonesia-Insolation," Gaisma, [Online]. Available: http://www.gaisma.com/en/location/jakarta.html. [Accessed 2013]. 


\section{Appendices}
A. JAP6 PV Module Data Sheet
B. FLEXmax Continuous MPPT Controllers Datasheet
C. Trojan T105 Battery Data Sheet
D. Boost Converter for the Distribution network and Battery Bank Specifications
E. SMA SUNNY BOY 10000TL-US Inverter Datasheet
F. ABB Single Phase Overhead Distribution Transformer 


\section{Appendix A}

\section{JAP6 PV Module Data Sheet}

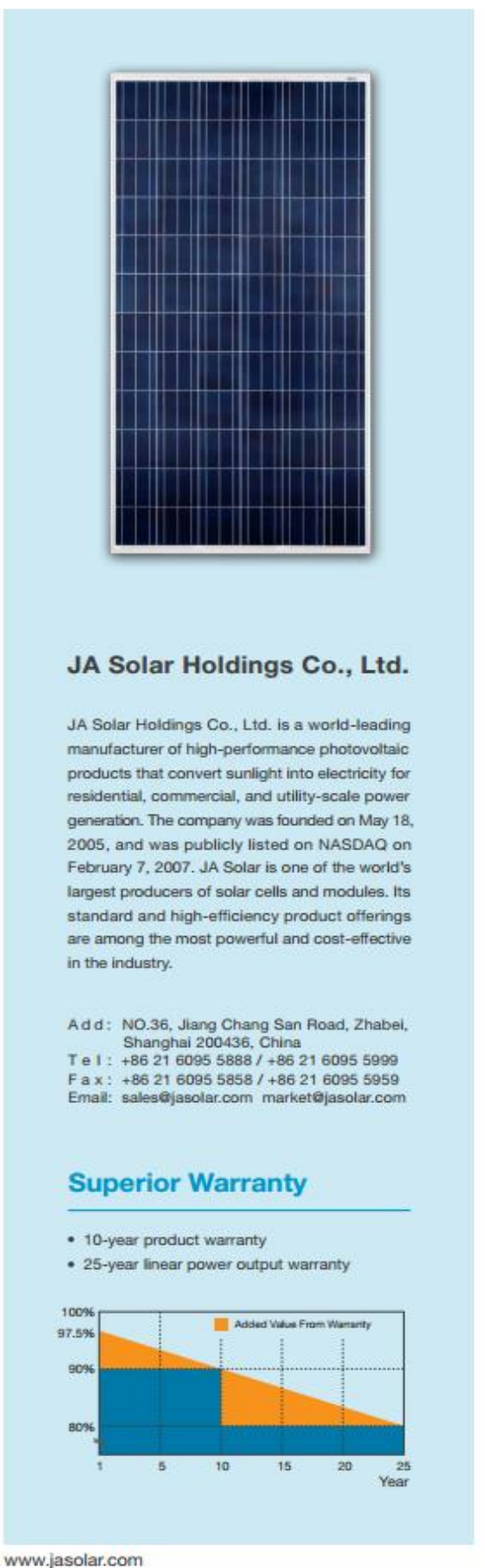

\section{$J A S O L A R$}

$72 / 280-310 / 3 B B$

MULTICRYSTALLINE SILICON MODULE

Key Features

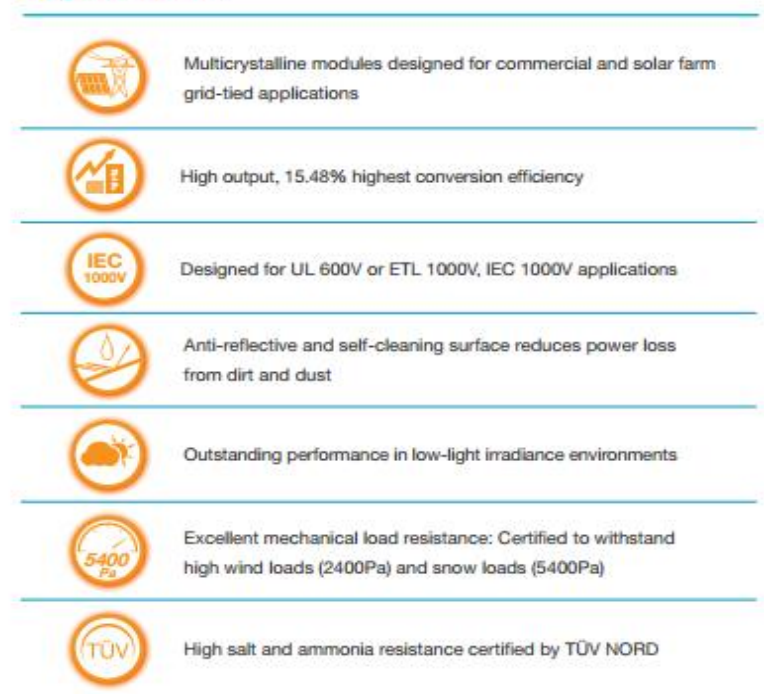

\section{Reliable Quality}

- Positive power tolerance: $0-+5 \mathrm{~W}$

- $100 \%$ EL double-inspection ensures modules are defects free

- Modules binned by current to improve system performance

- Potential Induced Degradation (PID) free

\section{Comprehensive Certificates}

- IEC 61215, IEC 61730, UL1703, CEC Listed, MCS and CE

- ISO 9001: 2008: Quality management systems

- ISO 14001: 2004: Environmental management systems

- BS OHSAS 18001: 2007: Occupational health and safety management systems

- Environmental policy: The first solar company in China to complete Intertek's carbon footprint evaluation program and receive green leaf mark verification for our products

Figure A-1: JAP6 PV Module Datasheet Page 1 


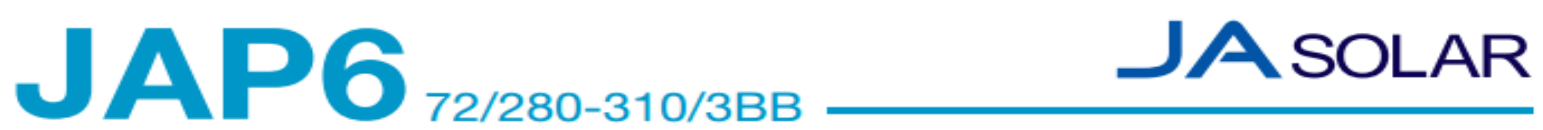

Engineering Drawings
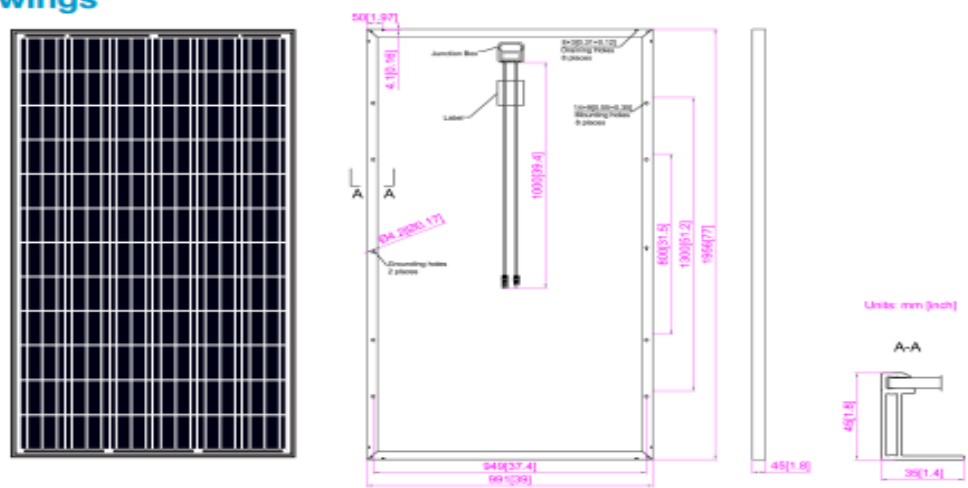

\section{MECHANICAL PARAMETERS}

Cell (mm) Poly $156 \times 156$

Weight (kg)

Dimensions $(\mathrm{L} \times \mathrm{W} \times \mathrm{H})(\mathrm{mm})$

Cable Cross Section Size ( $\left.\mathrm{mm}^{2}\right)$

No. of Cels and Connections

No. of Diodes

Junction Box Connector

Packaging Conflguration
22.5 (approx)

$1956 \times 991 \times 4$

4

$72(6 \times 12)$

3 or 6 ( 2 in paratel $)$

MC4 Compatible

22 Per Pallet

\section{WORKING CONDITIONS}

Maximum System Voltage

Operating Temperature

Maximum Series Fuse

Maximum Static Load, Front (e.g., snow and wind)

$5400 \mathrm{pa}\left(112 \mathrm{lb} / \mathrm{t}^{2}\right)$

NOCT

$47 \pm 2^{\circ} \mathrm{C}$

Application Class

Class A

\section{I-V CURVE}
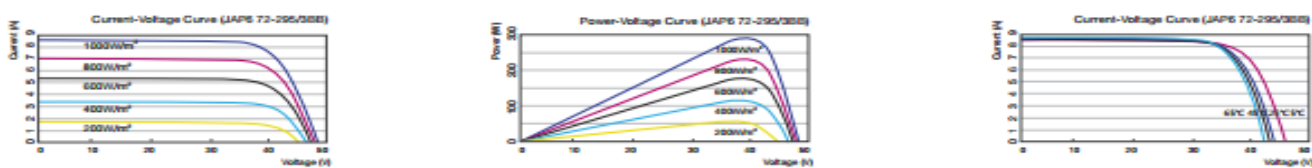

\section{ELECTRICAL PARAMETERS}

TYPE

Fated Maximum Power at STC (M) _ 280

Open Circuit Voltage ( $\mathrm{Voc} / \mathrm{N})$

Maximum Power Voltage ( $\mathrm{Vmp} / \mathrm{M}) \quad 35.99$

Short Circuit Current (lsc/A)

Maximum Power Current (Imp/A)

Module Efticiency [\%]

Power Tolerance $\mathrm{MW}$

Temperature Coefficient of lsc (alsc)

Temperature Coefficient of $\mathrm{Voc}$ (BVoc)

Temperature Coefficient of $\mathrm{Pmax}$ (YPmp) STC

\begin{tabular}{|c|c|c|c|c|c|c|}
\hline $72-28 a / 3 B B$ & LAP6 72-285/3BB & JAPE 72-290/3BB & JAP6 72-296/3BB & JAP6 72-300/3EB & JAP6 $72-305 / 3 B B$ & JAP6 $72-310 / 3 B E$ \\
\hline 280 & 285 & 290 & 295 & 300 & 305 & 310 \\
\hline 45.38 & 45.41 & 45.72 & 45.9 & 46.08 & 46.20 & 46.30 \\
\hline 35.99 & 36.08 & 36.39 & 36.60 & 36.82 & 36.97 & 37.04 \\
\hline 8.29 & 8.38 & 8.42 & 8.48 & 8.53 & 8.60 & 8.69 \\
\hline 7.78 & 7.90 & 7.97 & 8.06 & 8.15 & 8.25 & 8.37 \\
\hline 14.44 & 14.70 & 14.96 & 15.22 & 15.48 & 15.73 & 15.99 \\
\hline & & & $-0-+5 W$ & & & \\
\hline & & & $+0.062 \% / / C$ & & & \\
\hline & & & $-0.330 \% / \mathrm{C}$ & & & \\
\hline 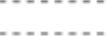 & & 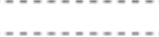 & $0.450 \% / \mathrm{C}$ & $\ldots$ & & \\
\hline & Irradian & $1000 \mathrm{~W} / \mathrm{m}^{2}$, Modo & Temperature $25^{\circ}$ & Air Mass 1.5 & & \\
\hline
\end{tabular}

JA Solar 10.2012

Figure A-2: JAP6 PV Module Datasheet Page 2 


\section{Appendix B}

\section{FLEXmax Continuous MPPT Controllers Datasheet}

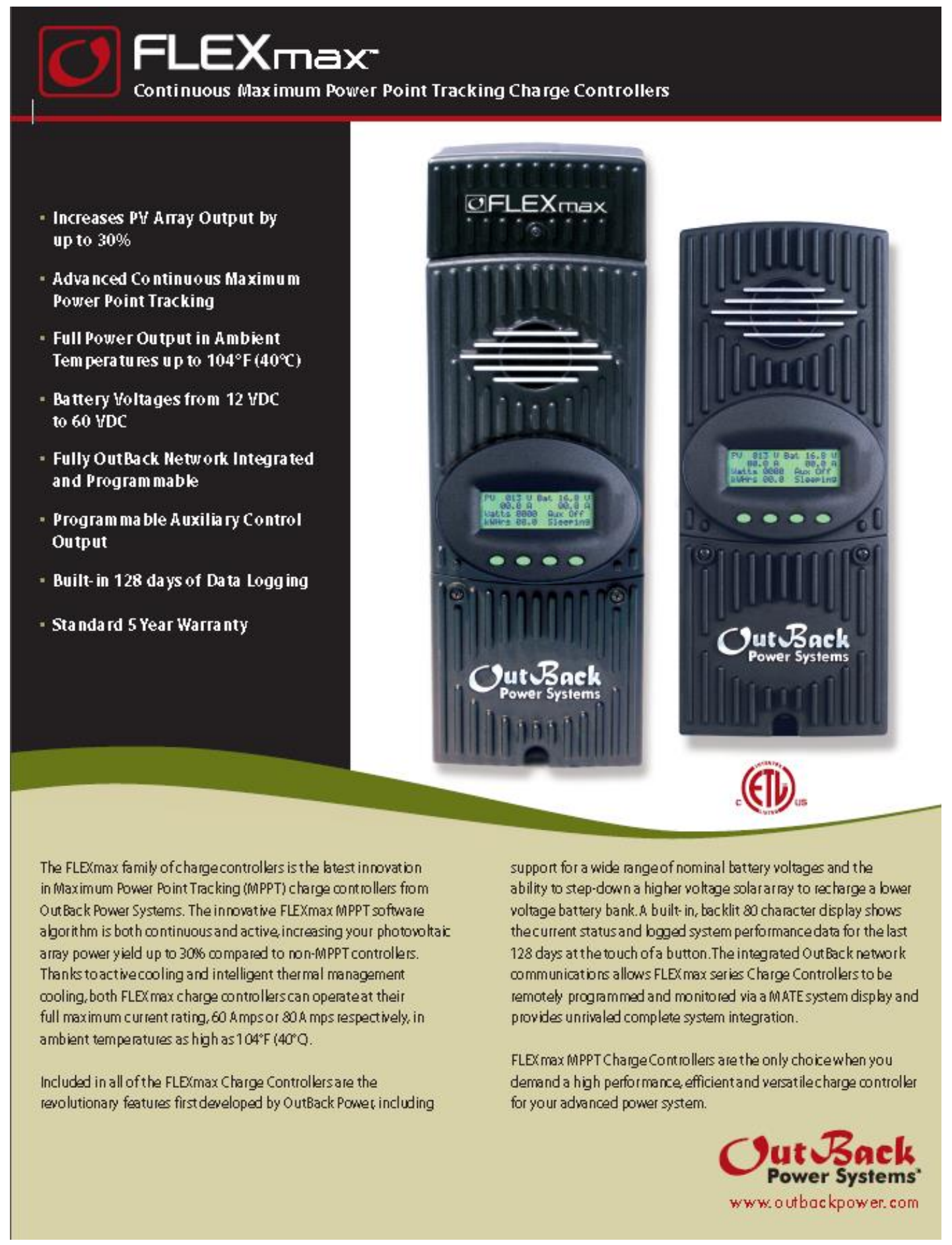

Figure B-1: FLEXmax Continuous MPPT Controllers Datasheet Page 1 


\section{FLEXmax Specifications}

\begin{tabular}{|c|c|c|c|}
\hline \multicolumn{2}{|c|}{ 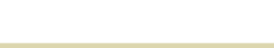 } & OFLEXmax日D - FMso-15ovDC & OFLEXmex-GD - FMEO-1 5OVDC \\
\hline \multicolumn{2}{|c|}{ Nominal Battery Loltages } & $\begin{array}{l}12,2436,48 \text { or } 60 \text { VDC S single model- selectable ví } \\
\text { field programmingat start-up) }\end{array}$ & $\begin{array}{l}12,24,36,48 \text { or } 60 \text { VDC S Single model-selectable ví } \\
\text { field programming at start up) }\end{array}$ \\
\hline \multicolumn{2}{|c|}{ MaximumOutputCurrent } & 80 amps @ $\left.104^{\circ} \mathrm{F}(40)^{\circ} \mathrm{C}\right)$ with adjustable curent limit & 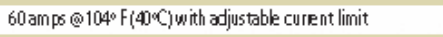 \\
\hline \multicolumn{2}{|c|}{ Maximum Sobr dếrray STC Nameplate } & 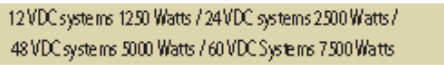 & 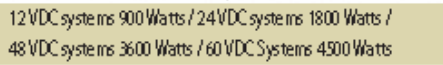 \\
\hline \multicolumn{2}{|c|}{ NECBeormmendedSda AmaySTCNamaqlate } & $\begin{array}{l}\text { 12VDC systems } 1000 \text { Watt } / 240 C \text { systems } 2000 \text { Watts } \\
48 v 0 C \text { systems } 400 \text { Watts / } 60 \text { VOC Systems } 5000 \text { Watts }\end{array}$ & 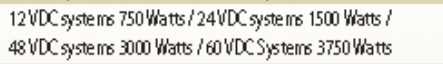 \\
\hline \multicolumn{2}{|c|}{ PWOpen Circuit Vottage(voc) } & $\begin{array}{l}150 v O C \text { absolute maximum coldest conditions/ } 145 v O C \\
\text { start-up and opeating maximum }\end{array}$ & $\begin{array}{l}150 v O C \text { absolue maximum coldst conditions/ } 145 \mathrm{vOC} \\
\text { start-up and operating max imum }\end{array}$ \\
\hline \multicolumn{2}{|c|}{ Standby Pouer Consumption } & Less than 1 Watt typizal & Less than 1 Watttypial \\
\hline \multicolumn{2}{|c|}{ Pouer Conversion Efficiency } & $975 \% @ 80 \mathrm{Mmps}$ in a $48 \mathrm{VDCSystem-Typizal}$ & $98.1 \% @ 60 \mathrm{dmps}$ in at 48 VDCSystem voltage - Typizal \\
\hline \multicolumn{2}{|c|}{ Charging Begubtion } & Five Stages: Bulk, Abrorption, Fost, Silent and Equa leation & Five Stages: Bulk, ú, brorption, Fbet, Silent and Equa lization \\
\hline \multicolumn{2}{|c|}{ Voltoge Regubtion Setpcint } & 10 to 60 voC use r adjustable with password protection & 10 to 60 voC use radjustable with password protection \\
\hline \multicolumn{2}{|c|}{ Equalieation Charging } & $\begin{array}{l}\text { Programmable Voltoge Setpoint and Duration - Automatic } \\
\text { Termination when completed }\end{array}$ & $\begin{array}{l}\text { Pogrammable Voltoge Setpoint and Duration - Automatic } \\
\text { Termination when completed }\end{array}$ \\
\hline \multicolumn{2}{|c|}{ Batery Temperature Compensation } & $\begin{array}{l}\text { Automatic with optional RTS installed } / 5.0 \mathrm{~m} U \text { per }{ }^{\mathcal{C}} \mathrm{Cper} \\
\text { 2W battery cell }\end{array}$ & $\begin{array}{l}\text { Automatic with cptional RTS installad } / 5.0 \mathrm{~m} V \mathrm{per}{ }^{\circ} \mathrm{C} \text { per } \\
2 \mathrm{~V} \text { battery cell }\end{array}$ \\
\hline \multicolumn{2}{|c|}{ VoltogeStep-Down Capability } & $\begin{array}{l}\text { Cancha rge a buer voltage battery froma higher woltage } \\
\text { PV array - Max } 150 v 0 \mathrm{C} \text { in put }\end{array}$ & 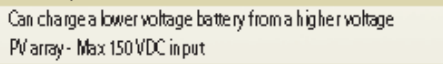 \\
\hline \multicolumn{2}{|c|}{ Programable IusialayContrd Quput } & $\begin{array}{l}\text { 12VOC output signal which can be programmed for different } \\
\text { control applications (Mtex imum of } 02 \text { amps DC) }\end{array}$ & $\begin{array}{l}\text { 12VDCoutput signal which an be programmed for different } \\
\text { control applications (Mtex imum of } 02 \text { amps } D C \text { ) }\end{array}$ \\
\hline \multicolumn{2}{|l|}{ Status Display } & $\begin{array}{l}3.11^{\prime \prime}(8 \mathrm{~cm}) \text { backlit LCDscreen - } 4 \text { lines with } 80 \text { alphan umeric } \\
\text { characters total }\end{array}$ & $\begin{array}{l}3.1^{\prime \prime}(8 \mathrm{~cm}) \text { backit LCD screen - } 4 \text { lines with } 80 \text { alphanumenic } \\
\text { characters btal }\end{array}$ \\
\hline \multicolumn{2}{|c|}{ Remote Disphy and Controller } & QpionalMate or Mate2 uith RS232 Serid Communications Port & OpionalMate or Mat2 2 vith RS232 Serial Communicaions Port \\
\hline \multicolumn{2}{|c|}{ NetworkCabeling } & $\begin{array}{l}\text { Proprietary networksystem using RJ } 45 \text { Modubr Con nectors } \\
\text { with CuT Se Cable( } 8 \text { wires) }\end{array}$ & $\begin{array}{l}\text { Poprietary networksystem using RJ45 Modular Connectors } \\
\text { with CuTSe Cable (8wirs) }\end{array}$ \\
\hline \multicolumn{2}{|l|}{ Deta Logging } & 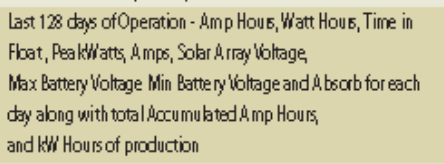 & 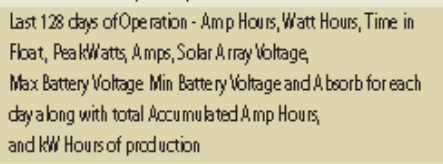 \\
\hline \multicolumn{2}{|c|}{ Hydo Turbine Â pplizations } & Consult factory for ap proved Turbines & Consult tactory for ap poved Turbines \\
\hline \multicolumn{2}{|c|}{ Positive Ground Ápplizations } & $\begin{array}{l}\text { Requies two Pole Breakers for switching both positive and } \\
\text { Negative Conductos on both Solar r. rray } \\
\text { and Batery Connections (HUB } 4 \text { and HUB } 10 \text { can not be used } \\
\text { br use in positive gound applizations) }\end{array}$ & $\begin{array}{l}\text { Requires two Pole Bealers for switching both poritive and } \\
\text { Negative Conductors on both Solar A. rray } \\
\text { and Battery Connections (HUB } 4 \text { and HUB } 10 \text { can not be used } \\
\text { for use in positive gound a ppliactions) }\end{array}$ \\
\hline \multicolumn{2}{|c|}{ Operating Temperatue Pange } & $\begin{array}{l}\text { Minimum- } 40^{\circ} \text { to maximum } 60^{\circ} \mathrm{C}(\text { Pone r capacity of the } \\
\text { controller is automatisally derated when operated above } 40^{\circ} \mathrm{C}\end{array}$ & $\begin{array}{l}\text { Minimum- } 40^{\circ} \text { to maximum } 60^{\circ} \mathrm{C} \text { (Pouer capacity of the } \\
\text { controller is automatically derated when operted above } 40^{\circ} \mathrm{C}\end{array}$ \\
\hline \multicolumn{2}{|c|}{ Environmental Räting } & Indoor Type 1 & Indoor Type 1 \\
\hline \multicolumn{2}{|c|}{ ConduitKnockouts } & $\begin{array}{l}\text { One 1" (35mmion the back One1"(35mm) on the left side; } \\
\text { Two 1"(35mm) on the bottom }\end{array}$ & $\begin{array}{l}\text { One 1" (35mmion the back; One1" (35 mm) on the left side; } \\
\text { Two 1"(35mm) on the bottom }\end{array}$ \\
\hline & & Standard 5 year / A vaila ble 10 Year & Standand 5 year / A vailable 10 Year \\
\hline \multirow{2}{*}{ Weight } & - Unit & $12.20 \mathrm{lbs}(5.56 \mathrm{lg})$ & $1165 \mathrm{lts}(5,3 \mathrm{~kg})$ \\
\hline & $\begin{array}{l}\text {-Shipping } \\
\text {-Unit }\end{array}$ & $\begin{array}{l}15.75 \mathrm{lbs}(7.10 \mathrm{~kg}) \\
1625^{\prime \prime} \times 5.75^{\prime \prime} \times 4^{\prime \prime}(413 \times 14 \times 10 \mathrm{~cm}) \cdot(\mathrm{H} \times \mathrm{W} \times \mathrm{D})\end{array}$ & $\begin{array}{l}14.55 \mathrm{lbs}(6.4 \mathrm{~kg}) \\
135 \times 5.75 \times 4^{\prime \prime}(40 \times 14 \times 10 \mathrm{~cm})\end{array}$ \\
\hline Dimensions & -Shipping & $21^{\prime \prime} \times 105^{\prime \prime} \times 9.75^{\prime \prime}(53 \times 27 \times 25 \mathrm{~cm})$ & $18 \times 11 \times 8^{\prime \prime}(46 \times 30 \times 20 \mathrm{~cm})$ \\
\hline \multicolumn{2}{|l|}{ Options } & 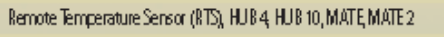 & 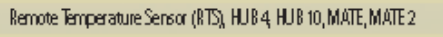 \\
\hline \multicolumn{2}{|c|}{ Menu Languages } & English \& Spanish & English \& Spanish \\
\hline
\end{tabular}

\section{Out Back}

Main office:

1900962 nd AvenueNE

Arrlington, WA 98223 USA.

Phone: (360) 435.6030

Fax: (360) 435.6019

www.outbackpower.com
European office:

C Castell $\delta, 17$

08830 - Sant Boi de Llobregat

BARCELONA, España

Phone: +34.93 .654 .9568$
OFLEXmex-6D - FMEO-1 5OVD fiet programming at start up)

60 amps $\left.104^{\circ} \mathrm{F}(4)\right)^{\circ} \mathrm{C}$ ) with adjustable curent limit 12 WOCsystems 900Watts/24WOCSystems 1800 Watts ? (a) 12 WOCsystems 750 Whats/24WOCSystems 1500 Watts / start-up and opeating maximum

ine Stage: Bulk, d. 10 to 60 vo user a justable with passuond protect tin $2 \mathrm{~V}$ battery cell

Gan charge a buter voltage battery froma higher woltose control applizations (Matimum of 02 amps DO characters btal

Opional Mate a Mat2 2uith RS222Seria Communicaions fort Poprietary networksystem usimg R/45 Modular Connecto with CATSeCable(8wires)

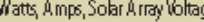
mulated a mp Hours both positiveand HUB 10 can not be used controller i automatically derated when operated abone $40^{\circ} \mathrm{O}$

mmion the leftsid

$135 \times 575 \times 4$ "1130 $\times 14 \times 10 \mathrm{~cm}$ English \& Spanish

Figure B-2: FLEXmax Continuous MPPT Controllers Datasheet Page 2 


\section{Appendix C}

Trojan T105 Battery Data Sheet

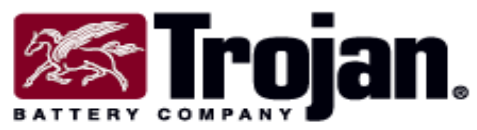

T105-RE DATA SHEET

MODEL:

T105-RE with Bayonet Cap

DIMENSIONS: inches (mm)

BATTERY: Flooded/wetlead-acid battery

COLOR: Maroon (case/cover)

MATERIAL: Polypropylene

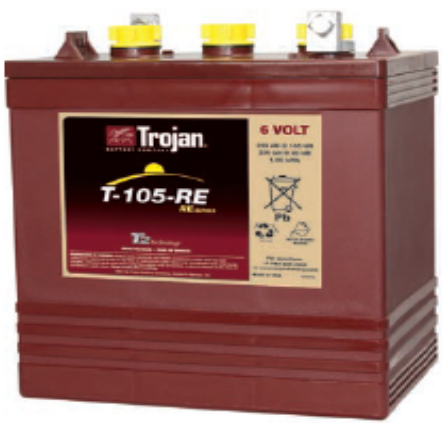

\section{RESERIES}

PRODUCT SPECIFICATION|WITH T2 TECHNOLOGY YM

\begin{tabular}{|c|c|c|c|c|c|c|c|c|c|c|}
\hline \multirow{2}{*}{$\begin{array}{c}\text { BOI } \\
\text { GPOUP } \\
\text { SIIE }\end{array}$} & \multirow[t]{2}{*}{ IVPE } & \multicolumn{3}{|c|}{ 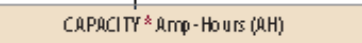 } & \multirow{2}{*}{$\begin{array}{c}\text { ENERGY (kWh) } \\
100 \text {-Hr linte }\end{array}$} & \multirow{2}{*}{$\begin{array}{c}\text { TERMAlNAL } \\
\text { Type }\end{array}$} & \multicolumn{3}{|c|}{ DIMANENDNSEE Inches (immi) } & \multirow{2}{*}{$\underset{(\mathrm{kg})}{\text { WE }}$} \\
\hline & & S.Hr Rate & 20 -Hr Rate & 100-Hr Rate & & & Length & With & Height ${ }^{c}$ & \\
\hline \multicolumn{11}{|c|}{6 VOLT DEEP CYCLE BAT TERY } \\
\hline $6 \mathrm{GCH}$ & T105-RE & 185 & 225 & 250 & 1.50 & 5 & $10-3 / 8(34)$ & 3-1/8(181) & $11-3 / 4,299$ & $67(300)$ \\
\hline
\end{tabular}

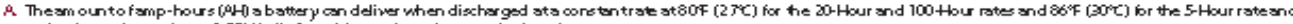

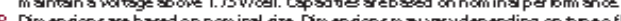

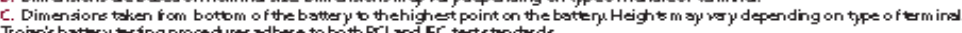

CHARGING INSTRUCTIONS

CHARGER VOLTAGE SETTINGS (AT $77^{\circ} \mathrm{F} / 25^{\circ} \mathrm{C}$ )

\begin{tabular}{|l|c|c|c|c|c|} 
System Voltage & $6 \mathrm{~V}$ & $12 \mathrm{~V}$ & $24 \mathrm{~W}$ & $36 \mathrm{~V}$ & $48 \mathrm{~V}$ \\
\hline
\end{tabular}

\begin{tabular}{|l|c|c|c|c|c|}
\hline Daily Chame & $7.2-7.35$ & $14.4-14.7$ & $28.8-29.4$ & $43.2-44.1$ & $57.6-58.8$ \\
\hline Float & 6.60 & 13.2 & 26.4 & 396 & 52.8 \\
\hline Equalize & 7.75 & 15.5 & 310 & 46.5 & 62.0 \\
\hline
\end{tabular}

$028 \mathrm{VPC}$ for every $10^{\circ} \mathrm{F}\left(5.55^{\circ} \mathrm{O}\right.$ aboure or below $77^{\circ} \mathrm{F}\left(25^{\circ} \mathrm{C}\right)$ iadd 028 VPC for every $10^{\circ} \mathrm{F}$ $\left(5.55^{\circ} \mathrm{O}\right.$ below $77^{\circ} \mathrm{F}$ and subtract $028 \mathrm{VPC}$ for every $10^{\circ} \mathrm{C}$ above $77^{\circ} \mathrm{F}$.

CHARGING TEMPERATURE COMPENSATION

$028 \mathrm{VPC}$ for every $10^{\circ} \mathrm{F}\left(5.55^{\circ} \mathrm{O}\right.$ aboure or below $77^{\circ} \mathrm{F}\left(25^{\circ} \mathrm{C}\right)$ (add $028 \mathrm{VPC}$ for every

$10^{\circ} \mathrm{F}\left(5.55^{\circ} \mathrm{C}\right)$ be bow $77^{\circ} \mathrm{F}$ and subtact $028 \mathrm{VPC}$ forevery $10^{\circ} \mathrm{C}$ abore $\left.77^{\circ} \mathrm{F}\right)$

\section{OPERATIONAL DATA}

\begin{tabular}{|l|l|}
\hline Operatung Temperature & Self-discharge \\
\hline $\begin{array}{l}4^{\circ} \mathrm{F} \text { to } 113^{\circ} \mathrm{F}\left(-20^{\circ} \mathrm{C} \text { to }+45^{\circ} \mathrm{C}\right) \text {. At temperatures } \\
\text { bebow } 32^{\circ} \mathrm{F}\left(0^{\circ} \mathrm{O} \text { maintain a state of charge }\right. \\
\text { greater than } 60 \% .\end{array}$ & $\begin{array}{l}5-15 \% \text { per month depending on } \\
\text { storage temperature conditions. }\end{array}$ \\
\hline
\end{tabular}

Figure C-1: Trojan T105 Battery Data Sheet Page 1 


\section{T105-RE DATA SHEET}

BATTERY DIMENSIONS (shown with LT)

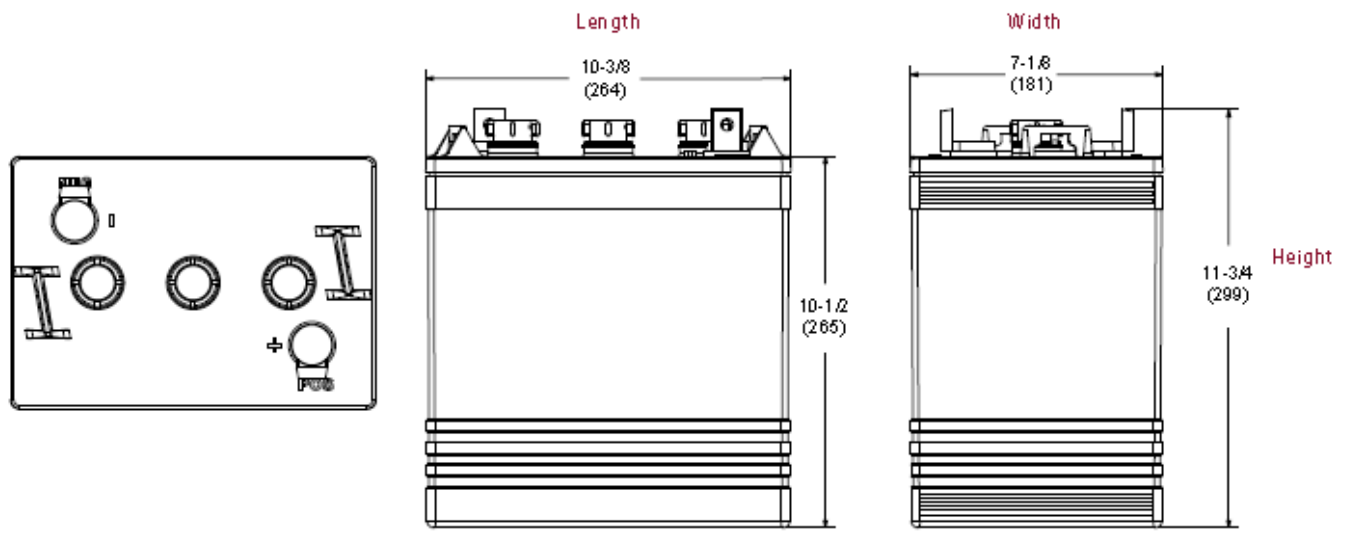

TROJANT 105-RE PERFORMANCE

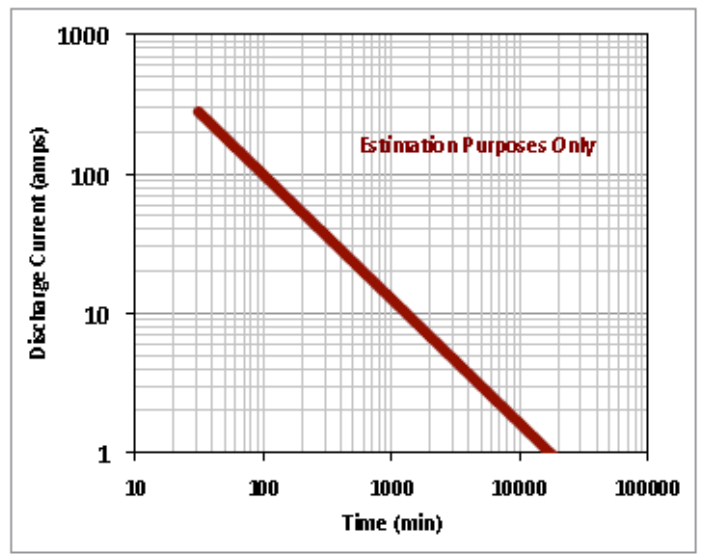

PERCENT CAPACITYVS. TEMPERATURE

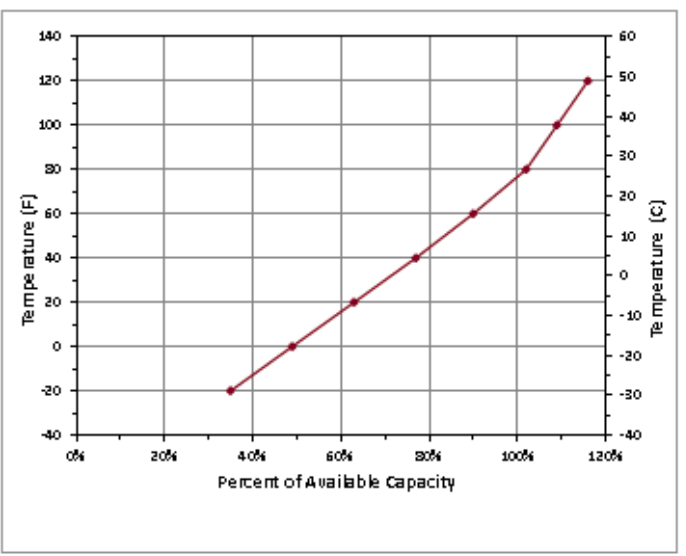

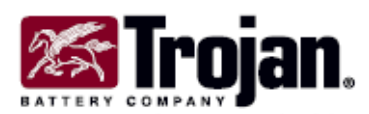

Clean energy for life.

Trojan batteries are available worldwide through Trojan's Mlaster Distribut or Network. We offer outstanding tectinical support, provided by full-t imeapplictionengineers.

For a Trojan Master Distributor near you, call 800.423 .6569 or +1.562 .236 .3000 or visit www.trojanbattery.com 12380 Clark Street, Santa Fe Springs, CA $90670+$ USA

Figure C-2: Trojan T105 Battery Data Sheet Page 2 


\section{Appendix D}

Boost Converter for the Distribution network and Battery Bank Specifications

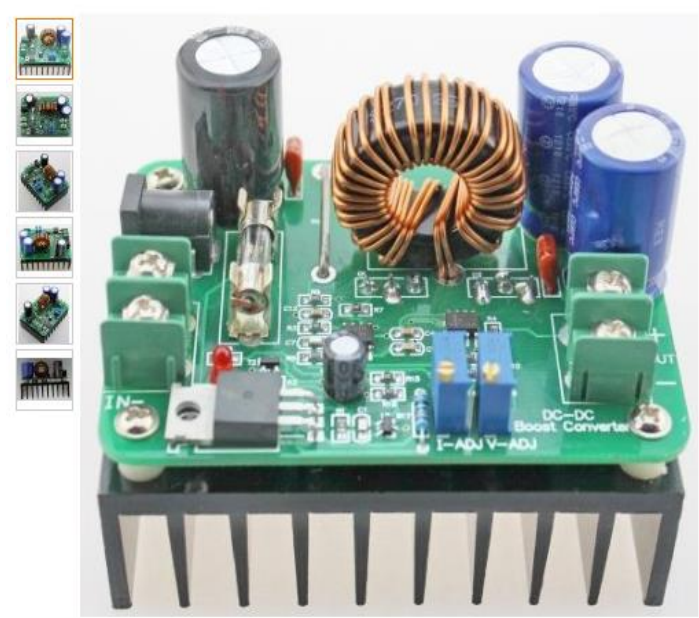

500W 600W 10A 10 60V to 12 80V DC-DC Switching Boost Converter Power Supply DIY

by BlueSolar

Be the first to review this item

Available from these sellers.

1 new from $\$ 28.10$

Share $\square+\mathbf{f} \otimes$

\section{Product Description}

Specification:

Module Properties: Step-up / Boost DC-DC Converter

Input Voltage: DC $10 \sim 60 \mathrm{~V}$

Output Voltage: DC $12 \sim 80 \mathrm{~V}$ ( adjustable, O/p Voltage $>\mathrm{I} / \mathrm{p}$ Voltage by $2 \mathrm{~V}$ )

Output Current: 10A Max

Input Current: 15 A Max( Under normal circumstances please 12A Current )

The minimum voltage difference: $2 \mathrm{~V}$

Output Power: input 12V Max 120W, in 24V Max 240W, in 60V Max 600W ( $\mathrm{P}=\mathrm{U} * \mathrm{I}$ )

Efficiency: $95 \%$ Max (eg input :30V output: $40 \mathrm{~V}$ 5A n: $93 \%$ )

Output Short-circuit Protection : yes

Input Reverse Protection: None

Size: $85 \times 63 \times 64 \mathrm{~mm}\left(\mathrm{~L}^{*} \mathrm{~W} \mathrm{~W}^{*} \mathrm{H}\right)$

Weight: $250 \mathrm{~g}$

Figure D-1: Boost Converter for the Distribution network and Battery Bank description 


\section{Appendix E}

SMA SUNNY BOY 10000TL-US Inverter Datasheet

\section{SMA}

\section{SUNNY BOY 8000TL-US / 9000TL-US / 10000TL-US}

\section{ra}

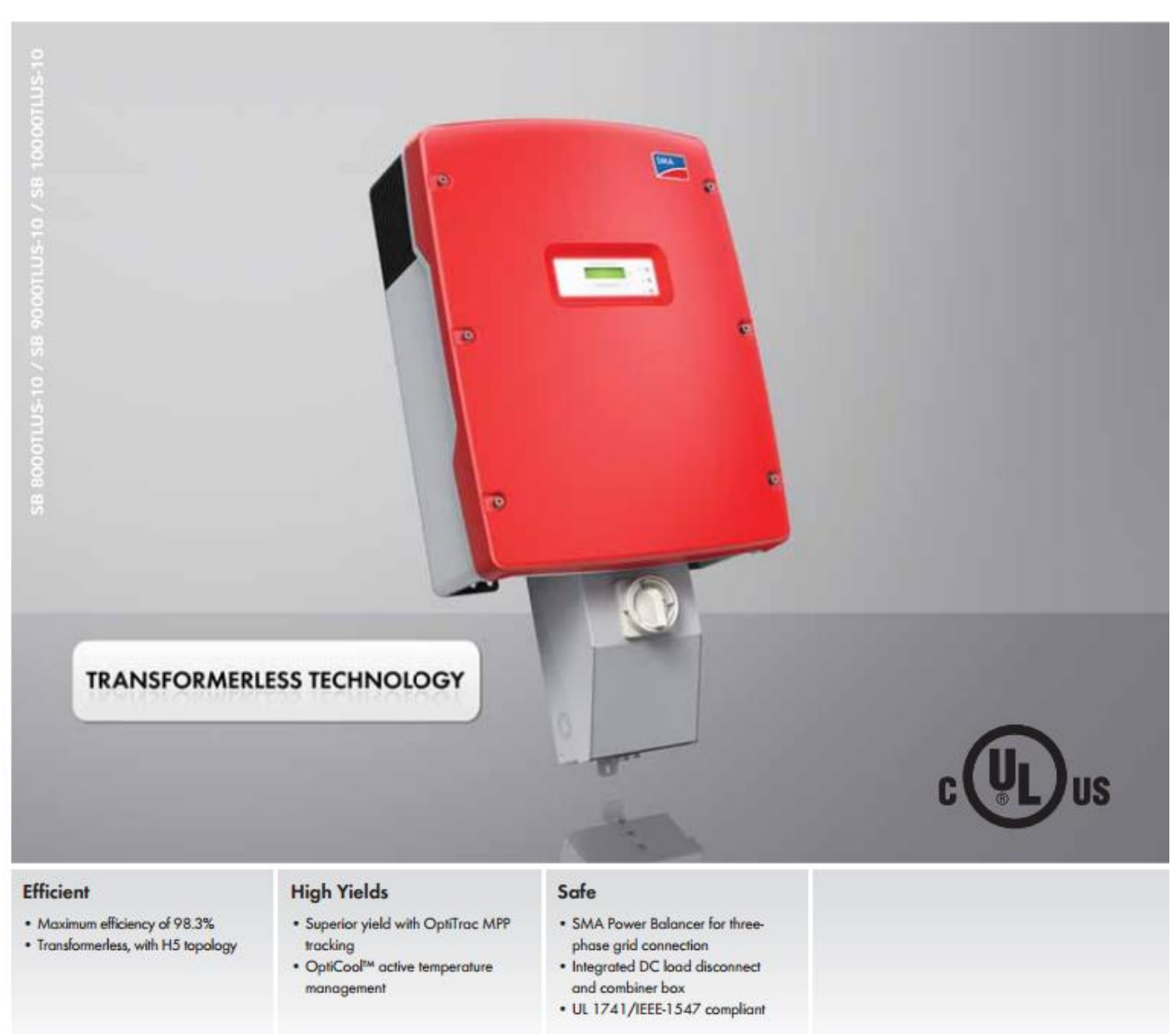

SUNNY BOY 8000TL-US / 9000TL-US / 10000TL-US

Transformerless design, maximum yields

The new Sunny Boy TL-US series is UL-listed for North America and features SMA's innovative H5 topology, resulting in superior efficiencies of up to 98 percent and unmatched solar yields. The transformerless design reduces weight, increases the speed of payback and provides optimum value for any decentralized, commercial PV system. The Sunny Boy TL-US series for North America is the ideal choice for mid-size and large plants from $24 \mathrm{kWp}$ up to the megawatt range.

Figure E-1: SMA SUNNY BOY 10000TL-US Inverter Datasheet Page 1 


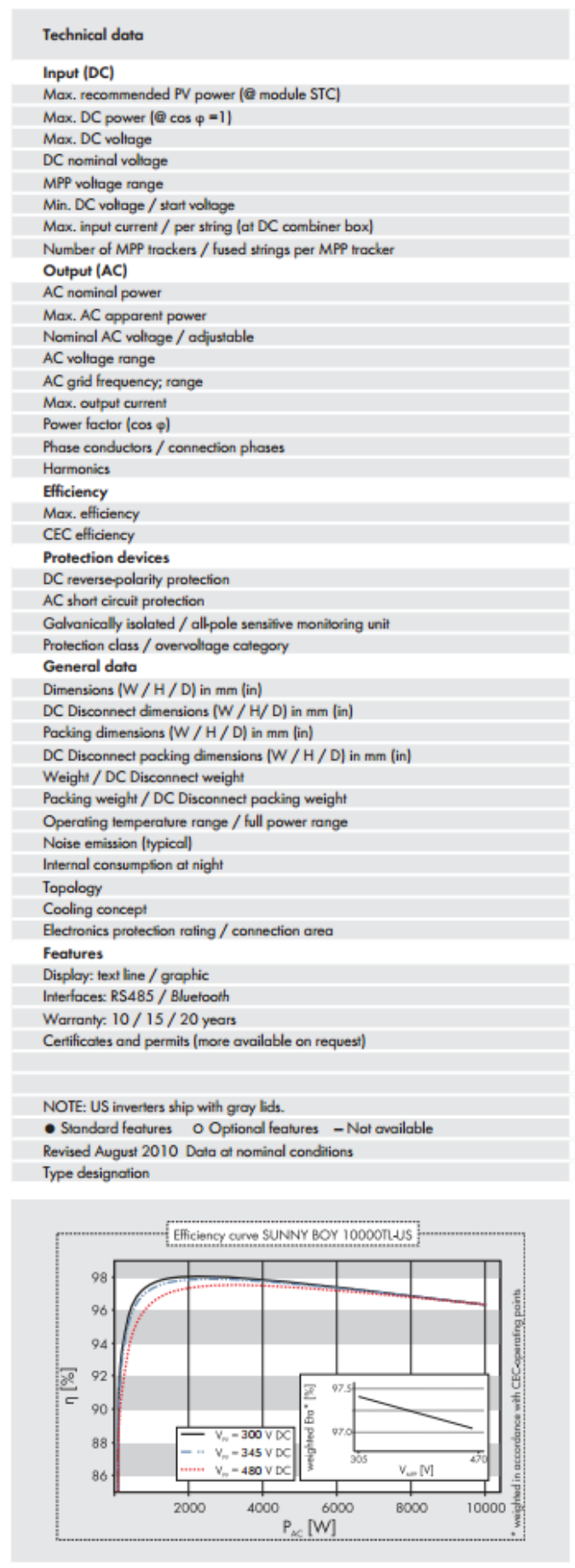

Toll Free +1 8884 SMA USA www.SMA-America.com

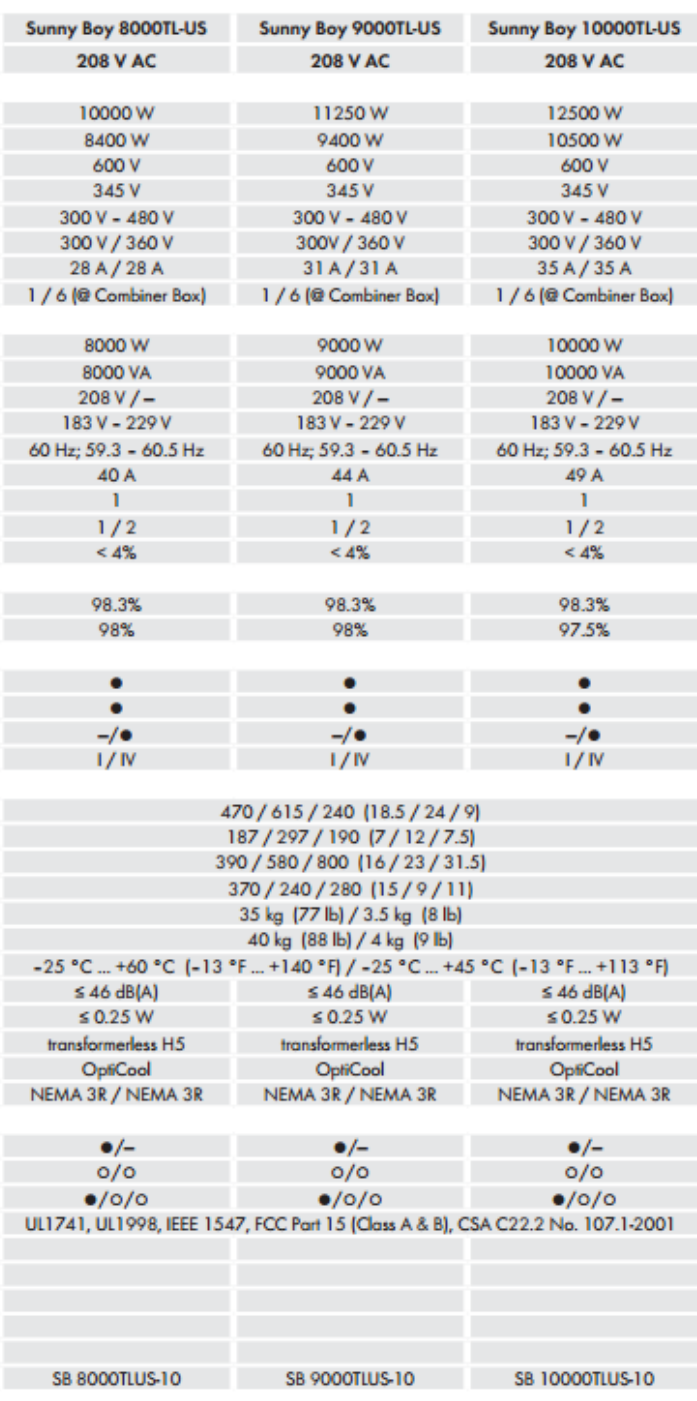

Accessories

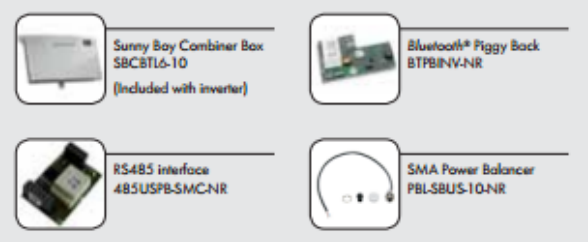

SMA America, LLC

Figure E-2: SMA SUNNY BOY 10000TL-US Inverter Datasheet Page 2 


\section{Appendix F}

ABB Single Phase Overhead Distribution Transformer

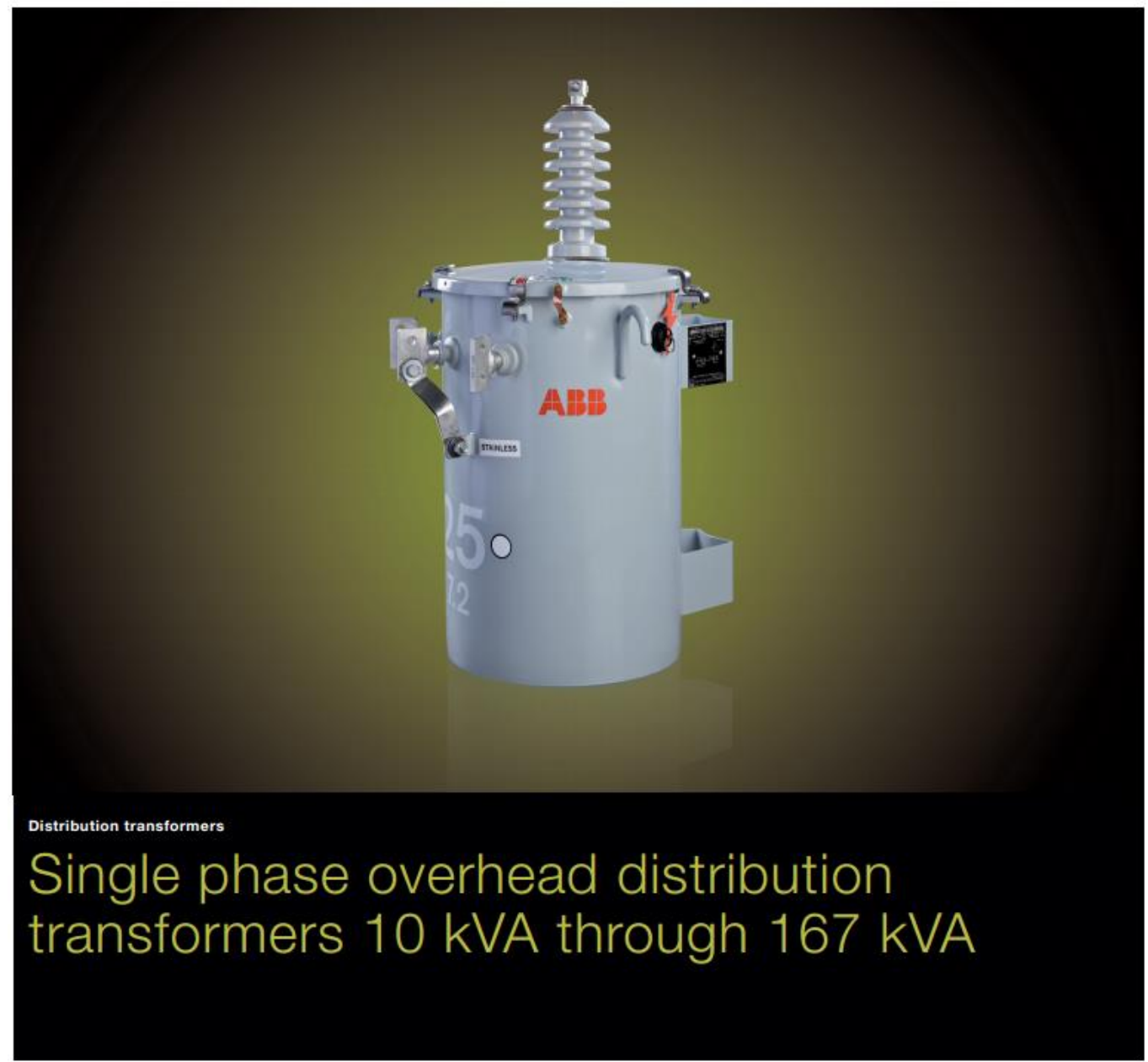

Figure F-1: ABB Single Phase Overhead Distribution Transformer Datasheet Page 1 


\section{Product overview}

Application

The ABB overhead transformer may be used alone for the supply of a single phase load or as one of three units in a bank for the supply of a three phase load. The unit may be directmounted to a wooden or concrete pole, or cluster mounted on a pole for three phase use. The ABB transformers are designed for servicing residential overhead distribution loads. They are also suitable for light commercial loads, industrial lighting and diversified power applications.

\section{Standards}

All units are built in accordance with both CAN CSA C2.1-06 and CAN CSA C2.2-06, except as modified to comply with customer specifications. IEEE C57.12.20 or International Electrotechnical Commission Standard (IEC) may apply if required.

Features

- Core and coils designed for an optimum Total Ownership Cost (TOC)

- Wound core with step-lap joints for increased efficiency and lower noise levels

- "Low-high-low" windings for increased short circuit strength, efficiency and thermal strength

- Computer aided design for mechanical \& electrical calculation (C.A.D.)

- Dual voltage designed to meet BIL and short circuit requirements on both connections

- Low voltage leads with embossed markings on all units with 3 LV bushings for easy reading and permanent identification on selected ratings

- Paint system meeting or exceeding the performance of the IEEE C57.12.28 Standard (para. 5.3 to 5.5 included), including the salt spray test

- Lifting lugs meeting all of the requirements of the CSA C2.1-06 and CSA C2.2-06 Standard (including feature to prevent sling slippage)

- Multiple cover clamps to ensure proper sealing and to minimize water retention on the cover edge

- Cover or sidewall mounted high voltage bushing(s) as required

- Low voltage spade or clamp type (basket) terminals as required

- Provision for surge arrester bracket, bracket available as an option

- Automatic self-resealing pressure relief valve

Dual Voltage Transformers and Taps

Dual voltage transformers have proven to be very useful for their versatility which allows lower inventories for the electric utilities

2 Single phase overhead distribution transformers and saves on change out costs in the event of upgrading to higher system voltage. Because taps are also in common use, it is appropriate that dual voltage transformers with taps be considered. As the transformer reliability is adversely affected by the increased number of HV leads introduced by dual voltage designs, ABB recommends the following:

- Dual Voltage transformers without taps should be limited to a $4: 1$ ratio ( eg $2.4 \times 8.0 \mathrm{kV}$ )

- If taps are required on both connections, the voltage ratio should be $2: 1$

Accordingly, ABB recommends that:

(1) dual voltage transformers without taps be limited to a maximum HV spread of $2400 \mathrm{~V} \times 8000 \mathrm{~V}$, or $4800 \mathrm{~V} \times 16000 \mathrm{~V}$, and that

(2) transformers with taps (for both connections) be limited to a maximum spread of 2.1 , for example $7200 \mathrm{~V} \times 14400 \mathrm{~V}$, or $8000 \mathrm{~V} \times 16000 \mathrm{~V}$

Pole Mounted Transformers, Rating Details

General technical information is listed below. Information on less common requirements can be obtained through your $\mathrm{ABB}$ sales representative.

- kVA: $10,15,25,37,50,75,100,167$

- Temperature rise : $65^{\circ} \mathrm{C}$

- Cooling type : ONAN

- Single Phase

- Hertz : 60, 50

- Polarity : Additive or Subtractive

- Primary Voltage : $2400 \mathrm{~V}$ through $34500 \mathrm{GrdY} / 19920 \mathrm{~V}$

- Secondary Voltage : 120 / 240V, 240 / 480 V, 347V, 600V

- Insulation Class : 25kV (150kV BIL) and below

- Taps: none, or as an option, 4 x 2,5\% HV (any combination of full capacity above nominal and /or reduced capacity below nominal)

Options

- Four HV winding taps complete with externally operated tapswitch

- Dual voltage primary complete with externally operated voltage switch

- Extra creep bushing

- Surge arrester bracket

- Internal Fault Detector (IFD)

- Non conductive transformer cover

- Biodegradable vegetable oil (BIOTEMP(R)

- Stainless steel tank and cover

Figure F-2: ABB Single Phase Overhead Distribution Transformer Datasheet Page 2 
The influence of the loss evaluation formulae on transformer designs will lead to a wide variety of sizes and weights, thereby making it difficult, for the purpose of this information sheet, to cover the broad range of dimensions.

\begin{tabular}{cccccccc}
\hline \multicolumn{6}{c}{ Typical Dimensions (mm) for grain oriented electrical design } \\
\hline KVA & A & B & C & \multicolumn{2}{c}{ D } & Mass (kg) & Oil (litres) \\
\hline 10 & 885 & 560 & 500 & 525 & 100 & 22 \\
\hline 25 & 935 & 610 & 560 & 590 & 160 & 30 \\
\hline 50 & 1035 & 710 & 635 & 675 & 260 & 60 \\
\hline 75 & 1035 & 710 & 745 & 840 & 375 & 90 \\
\hline 100 & 1135 & 815 & 770 & 965 & 555 & 100 \\
\hline 167 & 1335 & 1015 & 795 & 890 & 690 & 160 \\
\hline
\end{tabular}

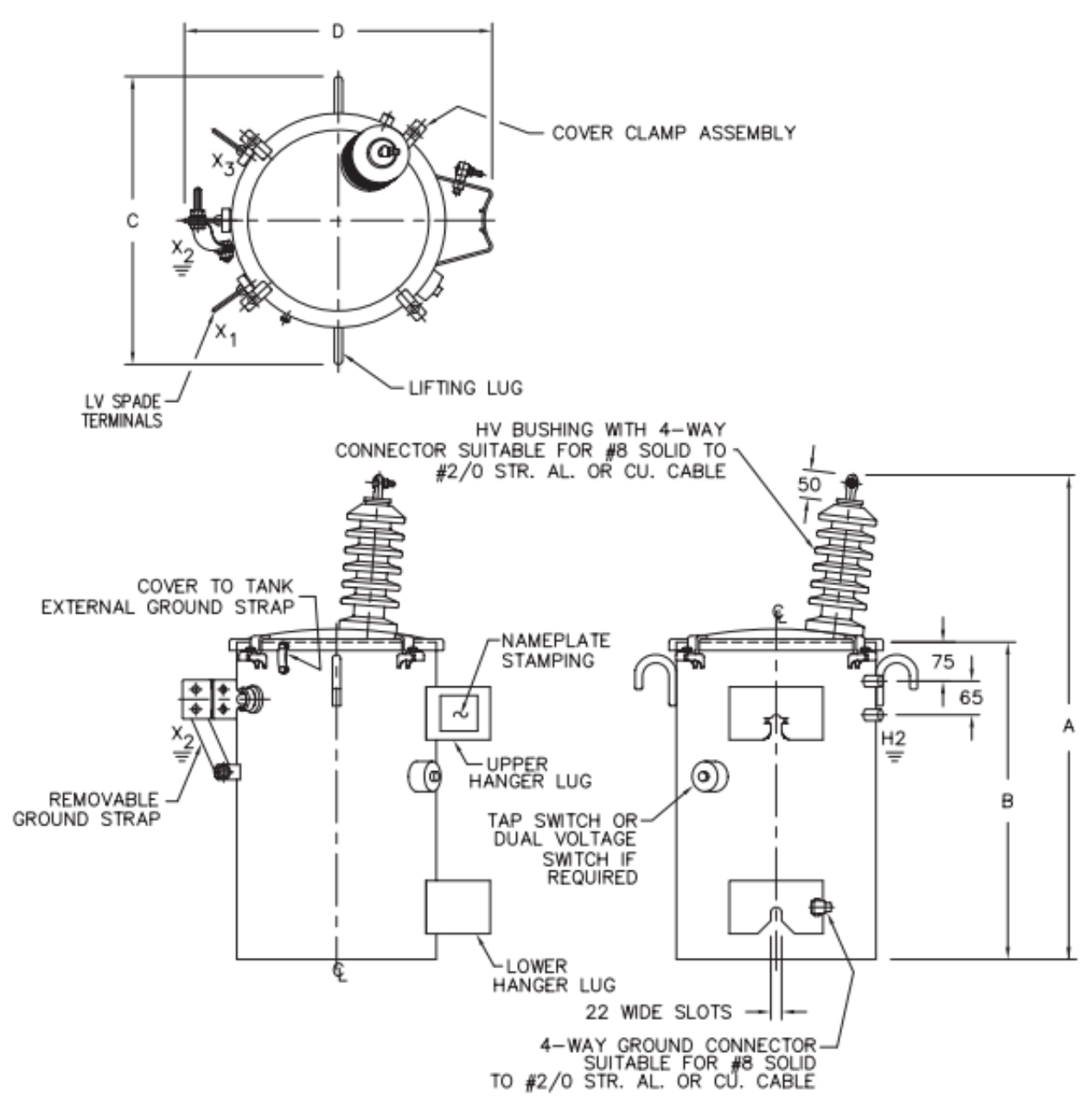

Single phase overhead distribution transformers 3

Figure F-3: ABB Single Phase Overhead Distribution Transformer Datasheet Page 3 